\title{
The role of human papillomavirus in the development of tonsillar squamous cell carcinomas
}

Citation for published version (APA):

Hafkamp, H. C. (2009). The role of human papillomavirus in the development of tonsillar squamous cell carcinomas. [Doctoral Thesis, Maastricht University]. Maastricht University.

https://doi.org/10.26481/dis.20090206hh

Document status and date:

Published: 01/01/2009

DOI:

10.26481/dis.20090206hh

Document Version:

Publisher's PDF, also known as Version of record

\section{Please check the document version of this publication:}

- A submitted manuscript is the version of the article upon submission and before peer-review. There can be important differences between the submitted version and the official published version of record.

People interested in the research are advised to contact the author for the final version of the publication, or visit the DOI to the publisher's website.

- The final author version and the galley proof are versions of the publication after peer review.

- The final published version features the final layout of the paper including the volume, issue and page numbers.

Link to publication

\footnotetext{
General rights rights.

- You may freely distribute the URL identifying the publication in the public portal. please follow below link for the End User Agreement:

www.umlib.nl/taverne-license

Take down policy

If you believe that this document breaches copyright please contact us at:

repository@maastrichtuniversity.nl

providing details and we will investigate your claim.
}

Copyright and moral rights for the publications made accessible in the public portal are retained by the authors and/or other copyright owners and it is a condition of accessing publications that users recognise and abide by the legal requirements associated with these

- Users may download and print one copy of any publication from the public portal for the purpose of private study or research.

- You may not further distribute the material or use it for any profit-making activity or commercial gain

If the publication is distributed under the terms of Article $25 \mathrm{fa}$ of the Dutch Copyright Act, indicated by the "Taverne" license above, 


\section{The role of human papillomavirus in the development of tonsillar squamous cell carcinomas}

Harriët Carina Hafkamp 
Lay-out: Legatron Electronic Publishing, Rotterdam

Printer: $\quad$ PrintPartners Ipskamp, Enschede (www.ppi.nl)

ISBN 978-90-9023843-2

\section{Copyright $\odot 2009$ H.C. Hafkamp}

All rights reserved. No part of this thesis may be reproduced or transmitted in any form, by any means, electronic or mechanical, without the prior written permission of the author, or where appropriate, of the publisher of the articles. 


\title{
The role of human papillomavirus in the development of tonsillar squamous cell carcinomas
}

\author{
PROEFSCHRIFT \\ Ter verkrijging van de graad van doctor \\ aan de Universiteit Maastricht, \\ op gezag van de Rector Magnificus, \\ Prof. mr. G.P.M.F. Mols
}

volgens het besluit van het College van Decanen,

in het openbaar te verdedigen

op vrijdag 6 februari 2009 om 14.00 uur

door

Harriët Carina Hafkamp 


\section{Promotiecommissie:}

\section{Promotores:}

Prof. Dr. J.J. Manni

Prof. Dr. F.C.S. Ramaekers

\section{Co-promotor:}

Dr. E.J.M. Speel

\section{Beoordelingscommissie:}

Prof. Dr. P.M. Steijlen (voorzitter)

Prof. Dr. A.J.M. Balm (NKI/AVL, Amsterdam)

Prof. Dr. B. Kremer

Prof. Dr. J.A. Kummer (Universitair medisch centrum Utrecht)

Prof. Dr. Ph. Lambin

The printing of this thesis was financially supported by:

ALK (Abelló), Artu Biologicals, Atos Medical BV, Dosmedical, Entercare, GlaxoSmithKline BV, Meditop,

Ooms allergie BV, Schering-Plough BV, Stallergenes, Wyeth Pharmaceuticals BV. 


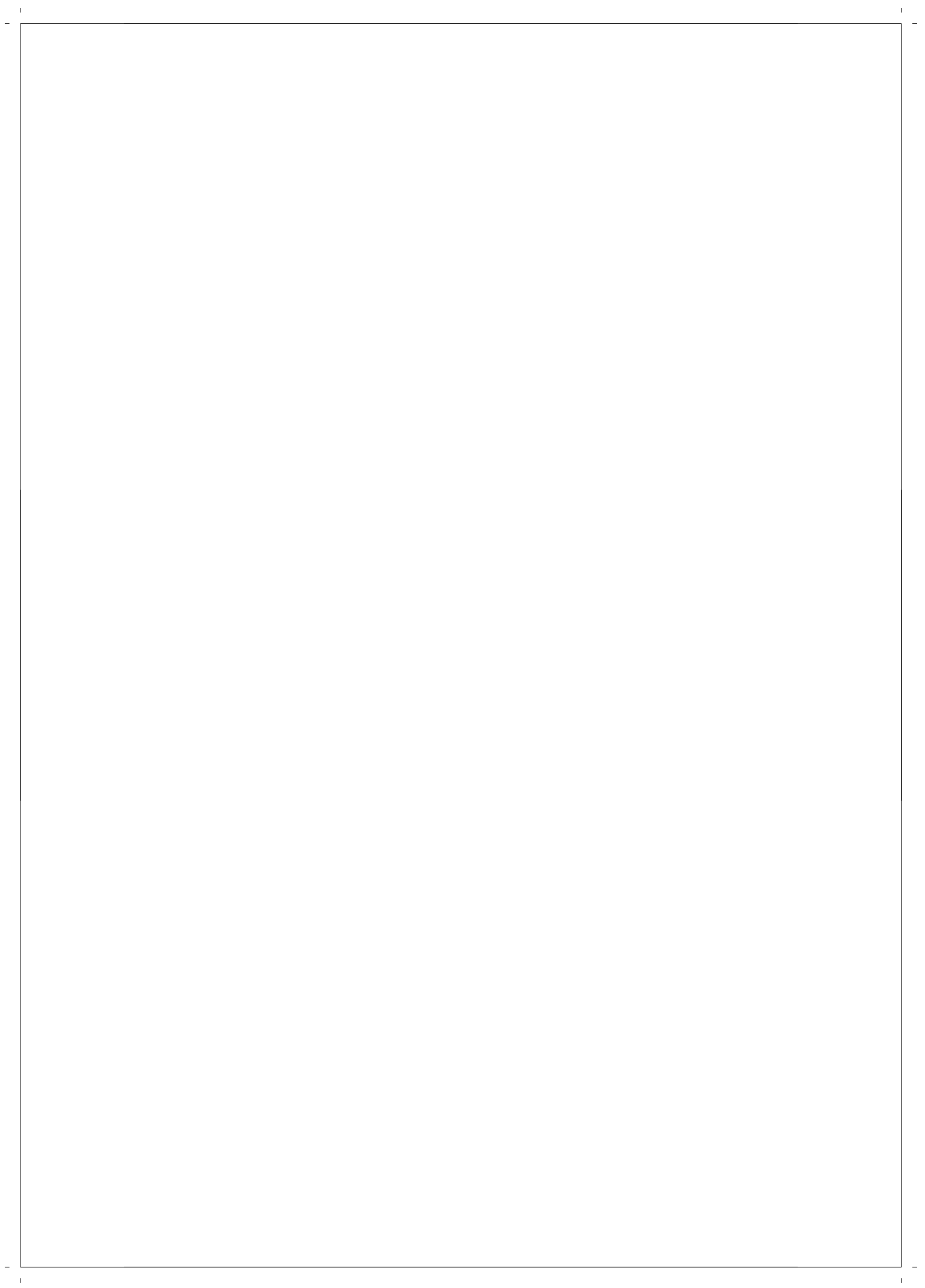




\section{Table of Contents}

Chapter 1 General introduction 9

Chapter 2 A subset of head and neck squamous cell carcinomas exhibits integration of hpv $16 / 18$ dna and overexpression of $\mathrm{p} 16^{\mathrm{INK} 4 \mathrm{~A}}$ and p53 in the absence of mutations in p53 exons 5-8

Chapter 3 Marked differences in survival rate between smokers and non-smokers with HPV 16-associated tonsillar carcinomas

Chapter $4 \quad \mathrm{p} 16^{\mathrm{INK} 4 \mathrm{~A}}$ overexpression is frequently detected in tumor-free tonsil tissue without association with HPV

Chapter 5 P21 1 Cip1/WAF1 expression is strongly associated with HPV-positive tonsillar carcinoma and a favorable prognosis

Chapter 6 General Discussion

Chapter 7 Summary

Samenvatting

Dankwoord

Curriculum Vitae

List of publications

List of abbreviations

Color figures 


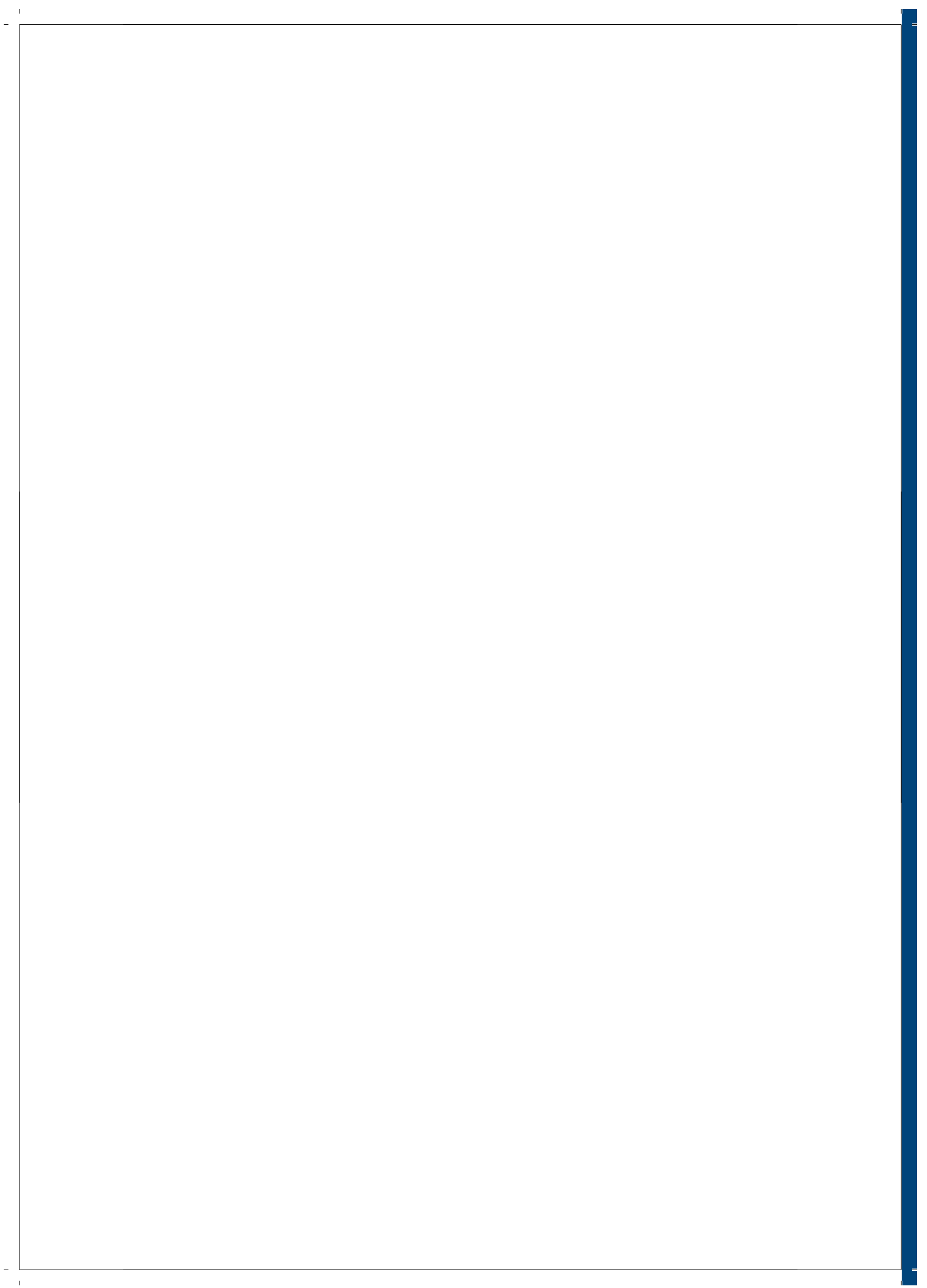




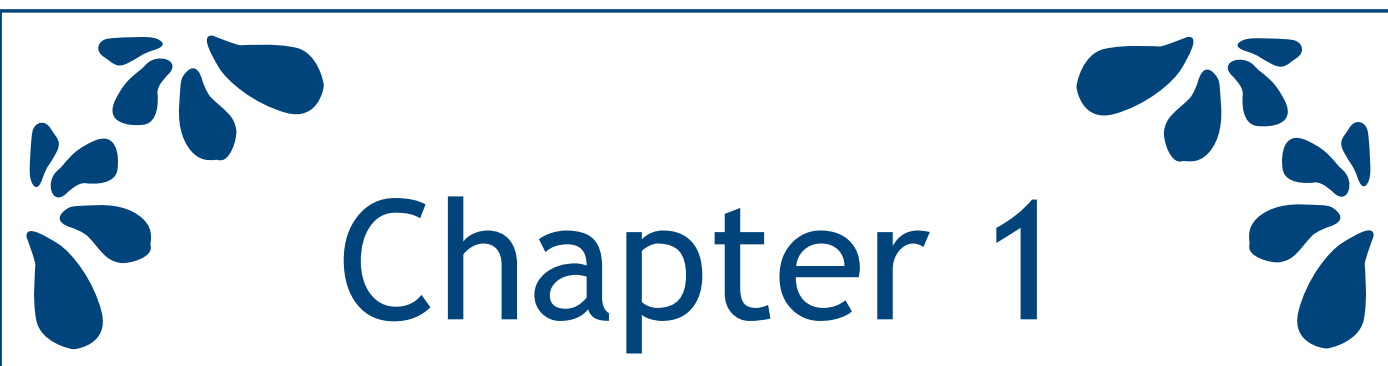

General introduction

Part of this chapter is published in:

Harriët C. Hafkamp, Johannes J. Manni, Ernst J.M. Speel

Role of human papillomavirus in the development of head and neck squamous cell carcinomas

Acta Otolaryngol 2004; 124: 520-6.

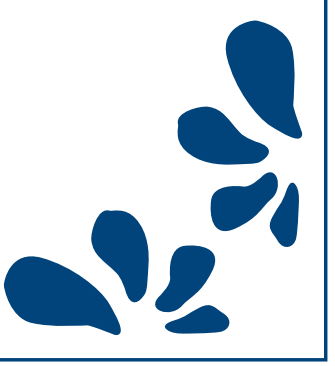




\section{Introduction}

Squamous cell carcinoma is the most prominent malignancy of the head and neck region. It develops from the mucosal lining of the upper aerodigestive tract, with the most frequently affected sites being the oral cavity, the oropharynx and the larynx (Figure 1). Head and neck squamous cell carcinomas (HNSCC) comprise about $5 \%$ of all newly diagnosed cancer cases in the Northern and Western European countries and the United States (US), and is the fifth most common cancer type worldwide ${ }^{1}$. The median age at presentation is 60 years and two-thirds of patients are men². Between 1985 and 1990 the world-wide incidence of cancer of the oral cavity and pharynx increased from 26.8 to 33.8 cases per $100000^{2,3}$.

In The Netherlands, the incidence of HNSCC is 15 cases per 100.000 citizens. In about 30\% of all new cases of HNSCC it concerns a laryngeal carcinoma. Between 1998 and 2003 there was a significant reduction in the incidence of these carcinomas in men ( 9.5 versus 6.6 per 100.000 men, respectively), whereas the incidence in women remained stable (1.3 per 100.000 women $)^{4}$. In 1989 the incidence of carcinomas of the oral cavity measured 4.1 per 100.000 for men and 2.7 per 100.000 for women. Since then an annual increase of $3.5 \%$ is detected in the total number of patients with these carcinomas. With an incidence of about 1 per 100.000, carcinomas of the hypopharynx are relatively rare. The incidence of these cancers remained stable between 1989 and $2001^{5}$. The incidence of oropharyngeal carcinomas was 2.4 cases per 100.000 for men and 1.2 cases per 100.000 for women in 1998. Between 1989 and 1998 the total fraction of patients with oropharyngeal carcinomas increased with about $5 \%$ annually. The increased incidence was mainly seen in the patient group of 45 to 59 years of age ${ }^{6}$.

A recent study of the US National Cancer Institute ${ }^{7}$ reviewing 45769 cancer cases between 1973 and 2004 also reported an increase in incidence of carcinomas arising from the oropharynx, particularly those of the base of the tongue, the lingual tonsil, the tonsil, and Waldeyer ring, whereas carcinomas arising from other subsites, such as other parts of the tongue, gum, mouth, and palate showed a reduction in incidence. This is in agreement with an earlier report of Frisch et al. ${ }^{8}$, describing a fourfold increase in the incidence of tonsillar squamous cell carcinoma (TSCC), which accounts for three quarters of all tonsillar malignancies ${ }^{9}$, among white women in Connecticut during 1945-1994, whereas in men there were annual increases of $2.7 \%$ in Afro-Americans and $1.9 \%$ in whites. No such increases could be observed at 
non-tonsillar sites. These data suggest that TSCC may differ etiologically from other

oral and pharyngeal cancers.

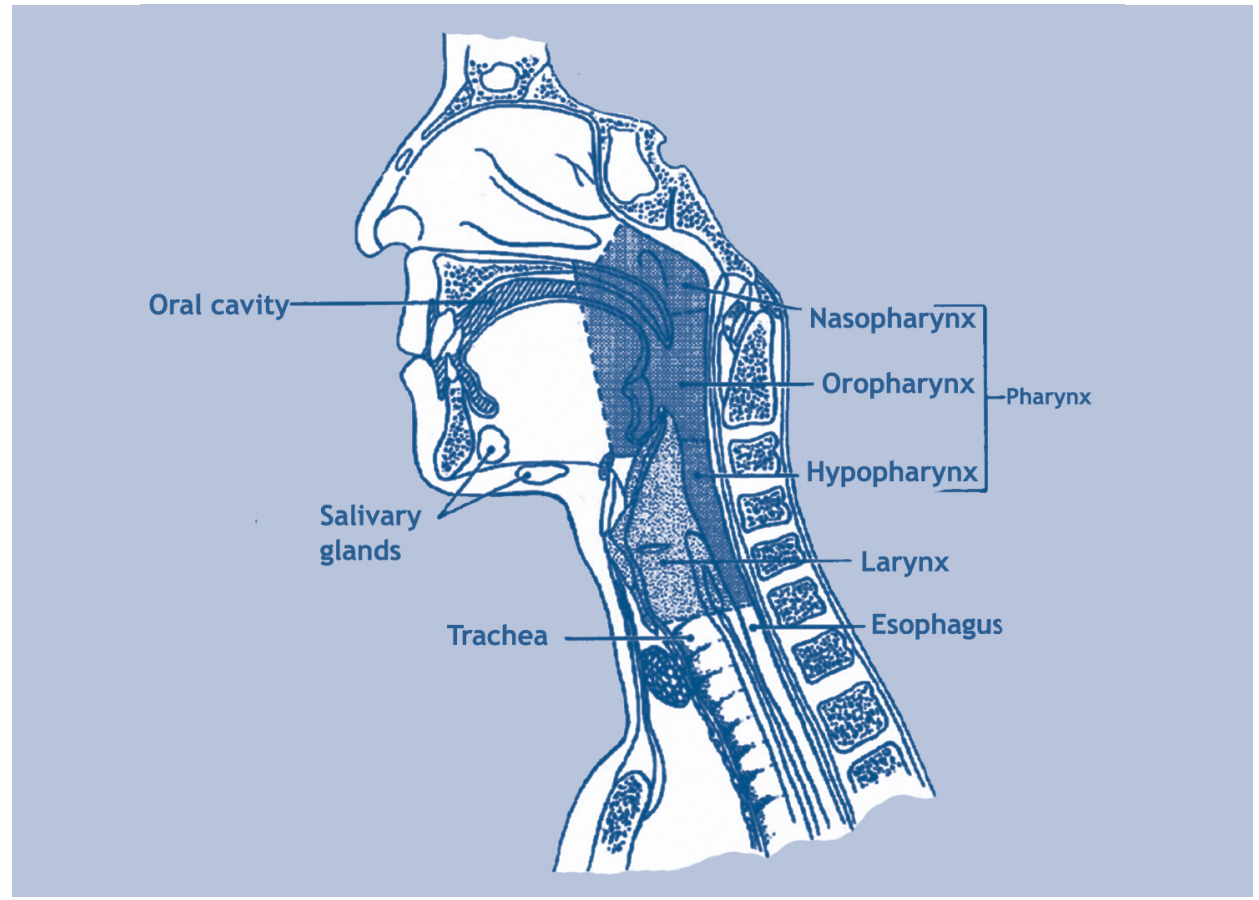

FIGURE 1. LATERAL VIEW OF THE MAIN SITES IN THE HEAD AND NECK REGION.

\section{Anatomy of the pharynx}

The pharynx is the common passageway for air and food extending from the nasal and oral cavities to the esophagus and larynx. The pharynx is divided into the nasopharynx, oropharynx and hypopharynx (Figure 1). The oropharynx is located between the soft palate and the upper edge of the epiglottis. It connects to the nasopharynx cranially, to the hypopharynx caudally, and to the oral cavity anteriorly. The tonsils form the boundary between the oropharynx and the oral cavity. The tonsils are embedded between an anterior and posterior fold extending from the soft palate to the tongue (Figure 2). The tonsils consist of lymphatic nodules lying in a subepithelial position, separated from underlying tissues by a connective tissue capsule. The lymphoid tissue of the tonsil is penetrated by deep crypts lined by 
stratified squamous non-keratinized epithelium that is continuous with the same type of epithelium overlying the tonsil. The epithelium of the tonsillar crypts is usually infiltrated by lymphocytes. The tonsils function as a first outpost of the body's immune defense system against bacteria, viruses and fungi entering the body through the mouth.

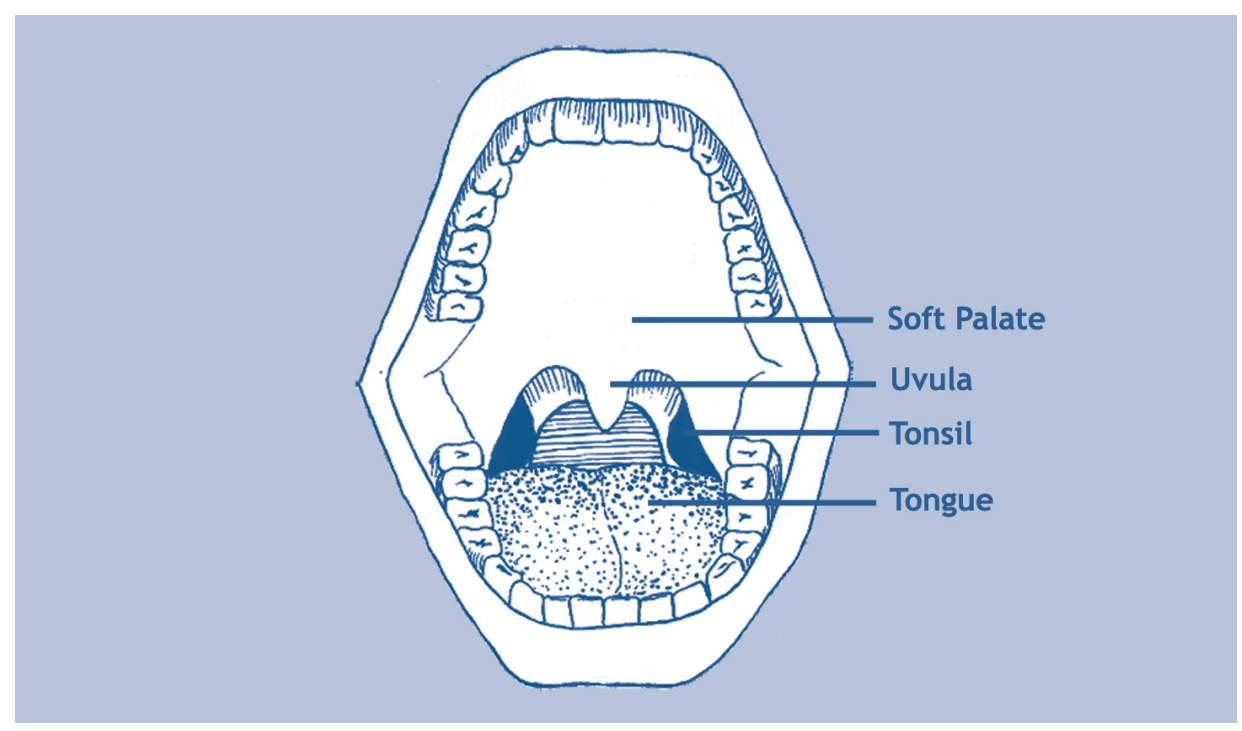

FIGURE 2. FRONTAL VIEW OF THE ORAL CAVITY.

\section{Etiology of HNSCC}

Tobacco smoking, extensive alcohol drinking and betel quid chewing are well-known risk factors in the etiology of HNSCC ${ }^{10,11}$. The age at which an individual starts smoking appears to be inversely associated with the relative risk of developing $\mathrm{HNSCC}^{10,12}$. Tobacco smoking and alcohol intake are independent risk factors, but a synergistic effect is observed when they are combined ${ }^{10}$. Other known risk factors include environmental exposure to wool dust, wood dust and mineral fibers, low intake of vegetables and fruit and infection with Epstein-Barr virus, which is strongly linked to the development of nasopharyngeal carcinoma ${ }^{10,13}$. Kreimer et al. ${ }^{14}$ suggested that a low body mass index might increase the risk of oral cancer, and that vegetables and fruits may modulate the carcinogenic effects of tobacco and alcohol. However, 
an increasing number of patients develop oral cancer in the absence of exposure

to the above-mentioned risk factors and independent of any obvious predisposing genetic defect, suggesting the presence of additional risk factors ${ }^{15,16}$.

In 1933, Shope and Hurst ${ }^{17}$ observed that infection with the cottontail rabbit papillomavirus led to the subsequent development of keratinous lesions, some of which progressed to invasive epithelial neoplasms. This observation led to the discovery of the first DNA virus that causes tumors in mammals. Substantial evidence now supports the role of human papillomavirus (HPV) in the development of (pre)malignant lesions of the vulva, penis, anus and uterine cervix ${ }^{18}$. In addition, epidemiological and molecular data suggest that HPV may also promote head and neck carcinogenesis ${ }^{18-23}$. A carcinogenic role for HPV is also suggested by the finding that patients with cervical cancer develop an excess of cancers in the head and neck region, especially of the oropharynx, in comparison with females with other cancers ${ }^{24}$. Schwartz et al. ${ }^{25}$ reported that HPV infection of the oral cavity is linked to an elevated cancer risk, independent of tobacco smoking and alcohol abuse, and that HPV may therefore be a risk factor for both uterine cervical cancer and $\mathrm{HNSCC}^{26}$. Indeed, individuals with detectable serum levels of antibodies against HPV16 demonstrate an approximately two-fold higher risk for developing HNSCC and an approximately ten-fold increased risk for developing tonsillar carcinomas, although only $37 \%$ of cases with HPV-positive HNSCC seem to have these antibodies in their serum ${ }^{27}$. Recently, a case control study of D'Souza et al. ${ }^{28}$ showed that a high lifetime number of vaginal-sex partners ( 26 or more) was associated with oropharyngeal cancer, as was a high lifetime number of oral-sex partners (6 or more). The degree of association increased with the number of partners. These findings have led to the hypothesis that some HNSCC, and particularly TSCC, are sexually transmitted diseases ${ }^{25,27}$.

\section{Head and neck carcinogenesis}

The development of cancer involves the accumulation of genetic and epigenetic alterations. These alterations include gain of function of growth stimulating genes, the oncogenes and loss of function of growth-inhibiting genes, the tumor suppressor genes. This process of activation of oncogenes and/or inactivation of tumor suppressor genes results in a cell population with an uncontrolled and increased 
growth potential as well as a decreased cell death fraction, which can evolve into a malignant tumor.

Head and neck cancer progresses through a series of well-defined clinically and histologically recognizable stages, reflecting the multi-step process of carcinogenesis (Figure 3). First, a hyperplastic lesion may develop in which the epithelial cells increase in number but individually exhibit a relatively normal differentiation behavior and normal morphology. Hyperplasia may then proceed to dysplastic lesions of the squamous cell epithelium that are characterized by cellular atypia and loss of normal maturation. When the lesion occupies the whole thickness of the epithelium, but stromal invasion has not taken place, it is classified as carcinoma in situ. Finally, the term invasive carcinoma is used when carcinoma cells invade the stomal compartment. In this stage the blood and lymph system may be reached by the invasive cells, which can result in further spreading of the cells through the body and the formation of regional or distant metastases. Multiple genetic changes have been identified that underlie the multistep carcinogenesis of the head and neck mucosa. In Figure 3 the most important genetic changes, as described in literature, have been implemented in a progression model of head and neck carcinogenesis ${ }^{29,30}$.

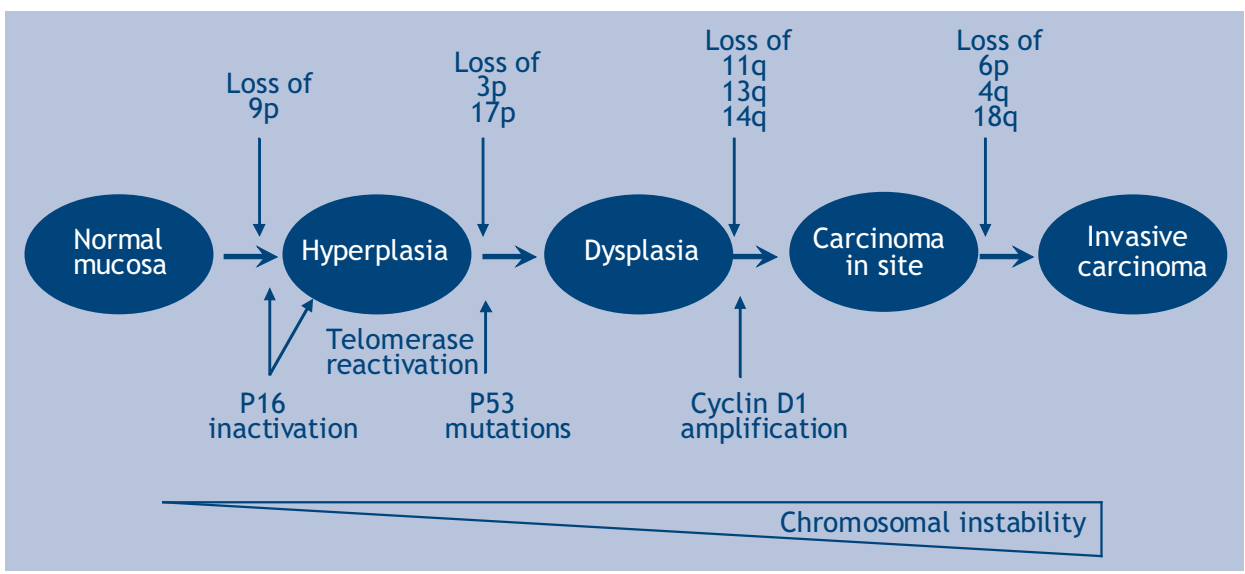

FIGURE 3. GENETIC PROGRESSION MODEL OF THE CARCINOGENIC PROCESS LEADING TO HNSCC. Important genetic alterations and candidate genes that are associated with the histopathological progression of HNSCC are indicated ${ }^{26,27}$.

Important events in the early tumorigenesis of HNSCC are losses of chromosomes 
$9 \mathrm{p} 21$ and 3p, which are accompanied by inactivation of tumor suppressor genes on the remaining chromosomes, such as $\mathrm{p} 16^{\mathrm{INK} 4 \mathrm{~A}}$ and FHIT. Furthermore, reactivation of telomerase and overexpression of EGFR are frequently identified as well as mutations in the p53 tumor suppressor gene in up to $50 \%$ of HNSCC. In the course of the tumorigenic process the number of molecular aberrations further increases, leading to chromosome instability, including DNA deletions and amplifications, such as those at $11 \mathrm{q} 13$ and $3 \mathrm{q} 26^{11,29-32}$.

Patients with HNSCC often suffer from multiple head and neck lesions, both premalignant and malignant. This phenomenon was originally described by Slaughter et al. in $1953^{33}$. These authors formulated the concept of field cancerization, meaning that a prolonged carcinogenic exposure of the entire mucosal lining of the upper aerodigestive tract results in multiple lesions that have acquired independent genetic changes. Later, an alternative theory has been proposed by Bedi et al. ${ }^{34}$ advocating intramucosal spread and expansion of (pre)malignant cells harboring identical genetic alterations as an explanation for the occurrence of multiple squamous cell lesions. The observation of unknown primary tumors harboring genetic alterations that are identical to those identified later in head and neck mucosa biopsies is also in accordance with the latter theory ${ }^{35}$.

\section{Human papillomaviruses}

HPVs are small epitheliotrophic DNA viruses of about $45-55 \mathrm{~nm}$ in diameter with circular double-stranded DNAgenomes of approximately $8 \mathrm{~kb}^{18}$. Based on their DNAand capsid structure they originally have been grouped together with the polyomaviruses to the family of Papovaviridae. Differences in genome size, organization and nucleic and amino acid sequences, however, have led to the separation of both virus groups in two different families, Papillomaviridae and Polyomaviridae ${ }^{36}$. The viral genome is organized into 3 segments: the long control region LCR (about 10\% of the genome), the early (E) E1, E2 and E4-7 genes (about 50\% of the genome) and the late (L) L1 and $L 2$ genes (about $40 \%$ of the genome) (Figure 4). The 8 HPV genes are designated as $E$ or $L$ according to their expression in early or late stage of the assembly process of the virus, respectively. As a result E1, E2, E5, E6 and E7 are expressed early in differentiation, E4 is expressed throughout, and L1 and L2 are expressed during the final stages of differentiation of the epithelium ${ }^{37}$. A new HPV 
subtype is defined if the E6, E7 and L1 regions display < $90 \%$ sequence homology with any other known HPV type ${ }^{38}$. Nearly 120 HPV genotypes have been identified so far, which are subdivided into benign subtypes on the one hand, and malignant or oncogenic subtypes on the other hand ${ }^{18,19}$. The benign subtypes, including HPV-6 and -11 , induce hyperproliferations of epithelia such as mucosal warts and papillomatosis. Recurrent respiratory papillomatosis of the larynx caused by HPV is the most common benign neoplastic disease of the larynx and is very difficult to treat ${ }^{39}$. Other subtypes, particularly HPV-16 and -18 , are strongly associated with malignancy.

HPVs are thought to infect proliferating cells in microlesions of the skin or mucosa (in the basal layer) or at the transformation zones between different types of epithelium, e.g. at the squamocolumnar junction of the uterine cervix ${ }^{40}$. Except for some limited expression of E5, E6 and E7, viral gene expression is largely suppressed in these cells. As a result of cell division HPV spreads laterally or migrates into the suprabasal differentiating cell layers. In these cells late viral gene expression is initiated, resulting in replication of the circular genome and production of structural proteins. In the upper cell layers, viral particles are assembled and released ${ }^{18}$.

So far, most HPV studies have concentrated on its role in the etiology of uterine cervical cancer ${ }^{18}$. In particular the high-risk oncogenic HPV types 16 and 18 induce preneoplastic lesions with an increased risk of progression to cancer. The transition from dysplasia to invasive cancer appears to be associated with integration of the viral DNA into the cellular host genome ${ }^{41}$. Recent studies suggest that mostly singular integration events occur by means of non-homologous sequence-specific recombination at a single locus or a few chromosomal loci (most probably fragile sites) in individual cell clones ${ }^{41-44}$. Molecular studies have shown that HPV integration results in disruption of the E1/E2 open-reading frames of the HPV genome, leading to increased expression of the E6 and E7 proteins in particular (Figure 4) ${ }^{18,19}$. 


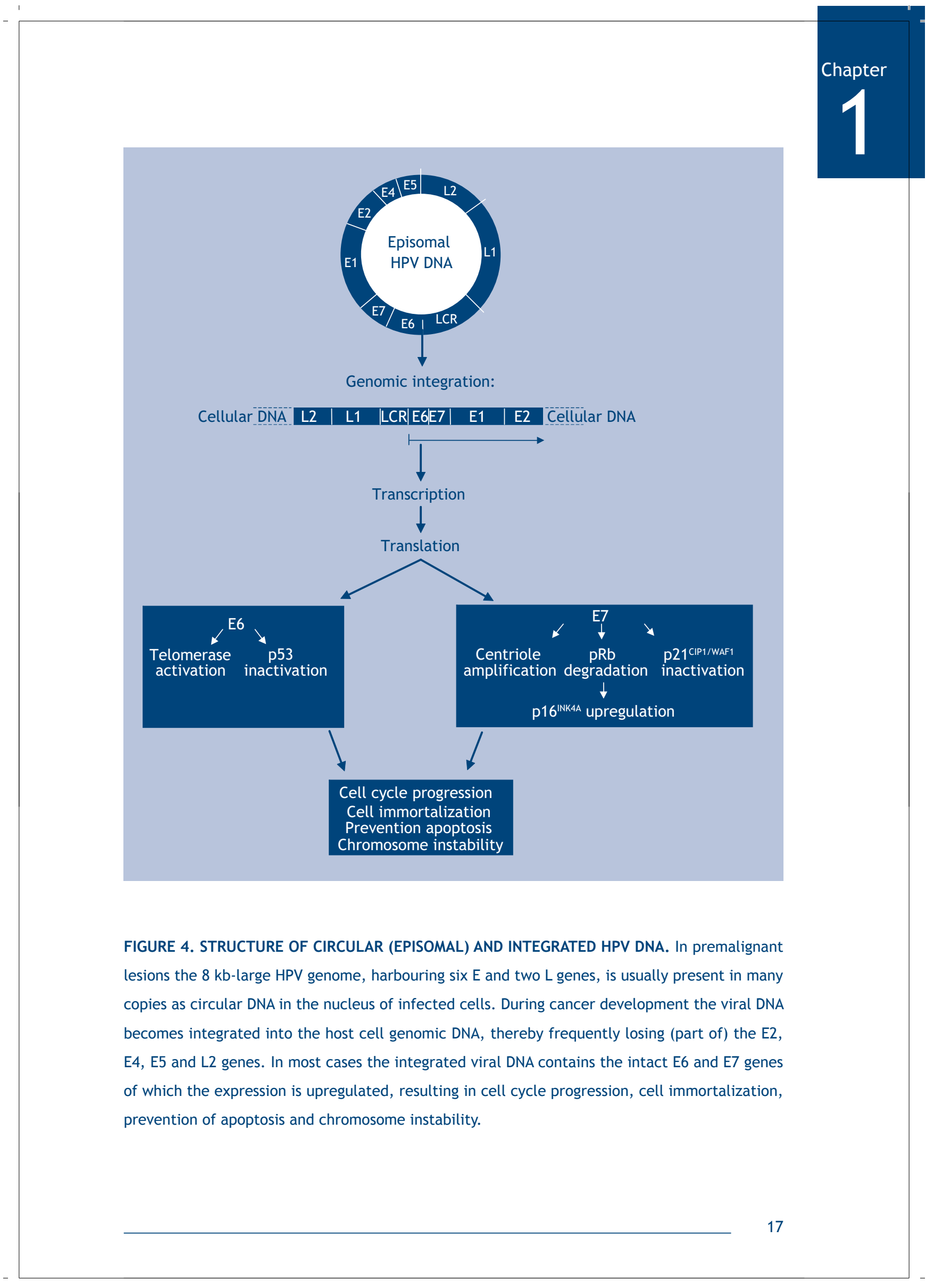




\section{HPV E5, E6 and E7 proteins}

The E5 protein is expressed in productive infections and may fulfill a function in the early expansion of an infected cell clone by activation of growth factor receptors or other protein kinases ${ }^{35}$. In uterine cervical carcinoma cells, however, the E5 open reading frame is frequently deleted, indicating the absence of an essential role of this gene in maintaining the malignant phenotype of cells.

Manydata areavailable relating to the function of theE6 andE7 oncoproteins ${ }^{18,19}$. They are consistently expressed in the majority of HPV-carrying malignant tumors. Although E6 and E7 proteins may independently promote carcinogenesis of human mucosal cells, their cooperative interaction leads to substantially enhanced cell immortalization ${ }^{45}$. Different interactions of the oncogenic E6 and E7 proteins with host-cell proteins have been reported. These data provide important clues towards understanding the oncogenic properties of the high-risk HPV types.

The HPV E6 protein can interact with the cellular wild-type p53 tumor suppressor protein, inducing p53 degradation via the ubiquitin-mediated pathway (Figure 4). Normally, p53 prevents cells with damaged DNA from progressing through the cell cycle by arresting them at the transition from the G1 to the S phase, thus allowing time for DNA repair. In the case of excessive DNA damage, the cell will undergo p53- and BAX-mediated apoptosis. Therefore, inactivation of p53 by E6 leads to deregulation of the cell cycle and promotes accumulation of mutations as well as chromosome instability. In addition, the E6 oncoprotein activates hostcell telomerase, a ribonucleotide protein complex that synthesizes telomere repeat sequences critical for cell immortalization during cell growth ${ }^{46}$. Furthermore, E6 binds to numerous other cellular proteins that can be divided into four broad classes: transcriptional co-activators, proteins involved in cell polarity and motility, tumor suppressors and inducers of apoptosis, and DNA replication and repair factors ${ }^{35}$.

The most important function of the E7 protein is its interaction with the cellular retinoblastoma tumor suppressor protein $(\mathrm{pRb})$, resulting in $\mathrm{pRb}$ ubiquitination and degradation by proteasomes ${ }^{18,47}$. As a consequence, the cyclin-dependent kinase 4/ 6 inhibitor $\mathrm{p} 16^{\mathrm{INK} 4 \mathrm{~A}}$ is upregulated and the transcription factor E2F is released, which activates both cell cycle progression by stimulation of the S-phase genes cyclin A and $E$, and viral DNA synthesis (Figure 4$)^{18}$. The importance of the binding of E7 to $\mathrm{pRb}$ is supported by the observation that there is a correlation between the ability of the E7 proteins to bind cell growth regulatory proteins and the oncogenicity of 
the HPV type. For example, the E7 protein from the oncogenic HPV types 16 and 18 binds pRb more strongly than does E7 from the benign HPV types ${ }^{48}$. Furthermore, E7

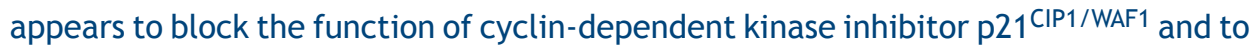
induce centriole amplification. These actions of the E7 protein further contribute to tumorigenesis by stimulating cell cycle progression and the development of genetic instability and aneuploidy (Figure 4) 18,35,49,50.

\section{HPV and head and neck cancer}

Epidemiological and molecular data have clearly indicated that oncogenic HPVs may promote head and neck tumorigenesis in the absence of more traditional risk factors such as tobacco smoking and alcohol consumption ${ }^{19-23}$. However, discrepancy exists with respect to the percentage of HNSCC harboring HPV, as the reported frequencies in head and neck lesions vary over a wide range (0-100\%). These differences may be due to the detection method used (Southern blot hybridization, polymerase chain reaction (PCR) or in situ hybridisation), the anatomic location of tumors, the type of HPV detected, and/or the number of tissue samples analyzed in the various studies. A 1998 review $^{19}$ of studies on HPV in head and neck lesions reported that: the frequency of HPV (both low and high risk types) in benign and precancerous lesions ranged from $19 \%$ to $36 \%$; the overall prevalence of HPV in HNSCC ranged from $18 \%$ (in situ hybridisation studies) to $35 \%$ (PCR studies); the majority of HPV-positive tumors contained the high-risk HPV types 16 (40\%) and 18 (12\%); and (iv) HPV was most often detected in tumors of the oral cavity (59\%), followed by those of the pharynx (43\%) and larynx (33\%).

As a result of more recent studies $20-23,51-53$ it has become clear that $15-25 \%$ of HNSCC harbor high-risk HPV types, which in about $90 \%$ of cases appears to be HPV-16, and that oropharyngeal carcinomas, particularly TSCC, are significantly more often HPV-positive (about 50\% of cases) than cancers in other locations. An important issue to consider here is the reliability of the PCR data, particularly in terms of providing evidence for a biological association between HPV and the tumor cells. If patients are to benefit in the near future from HPV-targeted therapeutic strategies (e.g. vaccines), then a clonal association between the virus and (a large proportion of) the tumor cells is a prerequisite ${ }^{54}$. Several reports, however, have shown that up to $50 \%$ of cases that tested positive for high-risk HPV types using PCR 
turned out to be negative in control experiments using Southern blotting and reverse transcriptase PCR to determine E6/E7 mRNA expression levels $21,22,54,55$. This may be due to contamination or to the detection of "biologically irrelevant" HPV copies in the DNA extracts using PCR. Therefore, control experiments are essential in order to help improve estimates of the proportion of HNSCC for which there is a biologically relevant association with $\mathrm{HPV}^{56}$. Alternative approaches for doing so include the detection of high-risk HPV DNA by multiplex PCR or PCR analysis of microdissected tumor cells, demonstrating viral load data between 1 and 150 HPV DNA copies per B-globin copy ${ }^{51}$, or use of highly sensitive fluorescence in situ hybridization (FISH) protocols ${ }^{23,57}$. The FISH procedure enables HPV DNA detection up to the level of a single copy per cell nucleus, and to discriminate between replicative (episomal) and integrated virus on the basis of the nuclear staining pattern. In this way HPV association with the tumor can be directly analyzed under the microscope. Because of these advantages of the FISH procedure over the other detection methods we decided to use the FISH procedure in our studies.

Detailed epidemiological data concerning the normal course of high-risk HPV infection in the oropharyngeal region are unavailable at present. Therefore, and because premalignant lesions of the oropharynx are scarcely observed in the clinic, studies on the prevalence of HPV-16 and -18 in normal mucosa of healthy tonsils, as well as carcinoma containing tonsils, using cytological tissue samples, biopsies or resection material, should shed further light on their role in promoting oropharyngeal carcinogenesis ${ }^{58-61}$.

\section{Clinical course}

With respect to the clinical course and prognosis of HPV-related HNSCC, varying observations have been reported. Most authors describe a survival advantage of HPVpositive HNSCC patients when compared to HPV-negative cases ${ }^{21,52,62,63}$, while others show the opposite result ${ }^{64}$ or could not show a difference in survival outcome ${ }^{65,66}$. In addition, it has been suggested that the clinical course of the disease might be gender-specific, since males with a HPV-positive tumor had a better prognosis than males with a HPV-negative tumor, whereas this correlation could not be detected in women ${ }^{52}$. It has also been postulated that HPV would be more prevalent in younger 
patients $^{65}$. Some studies describe that HPV-positive tumors have a better response to radiation and chemo- therapy compared to HPV-negative tumors ${ }^{67}$.

It is evident from the foregoing that more detailed prognostic studies are needed before HPV status can affect clinical decision making.

\section{Outline of this thesis}

As described above, it is obvious that, besides the well known risk factors such as tobacco smoking and alcohol intake, HPV also plays an important role in the development of HNSCC. Despite the evident association of HPV with HNSCC in a subgroup of patients, the exact mechanisms by which the virus causes tumor initiation and progression are not fully understood.

In this thesis the hypothesis is put forward that HPV-positive and HPV-negative tonsillar squamous cell carcinomas are two different entities.

The following questions were raised:

1) Can we detect integrated DNA of oncogenic HPV in premalignant lesions, HNSCC and their metastases?

2) Since overexpression of p53 is frequently observed in HNSCC, the question had to be answered whether this is related to the presence of HPV and/or the result of p53 mutations.

3) What is the impact of HPV, tobacco smoking and other risk factors on the clinical course of TSCC?

4) Can p16 ${ }^{1 \mathrm{NK} 4 \mathrm{~A}}$ overexpression reliably be used as a surrogate marker for HPV infection in head \& neck cancer and predict the presence of HPV in normal tonsil tissue?

5) Which key cell cycle proteins in the retinoblastoma (pRb) en p53 pathways are involved in HPV-related carcinogenesis of TSCC, and are these proteins related to a favorable prognosis? 


\section{References}

1. Pisani P, Bray F, Parkin DM. Estimates of the world-wide prevalence of cancer for 25 sites in the adult population. Int J Cancer 2002;97:72-81.

2. Parkin DM, Pisani P, Ferlay J. Estimates of the worldwide incidence of twenty-five major cancers in 1990. Int J Cancer 1999;80:827-41.

3. Parkin DM, Pisani P, Ferlay J. Estimates of the worldwide incidence of eighteen major cancers in 1985. Int J Cancer 1993;54:594-606.

4. Nederlandse werkgroep hoofd-halstumoren. Revisie richtlijn larynxcarcinoom 2007.

5. $\quad$ Nederlandse werkgroep hoofd-halstumoren. Richtlijn hypopharynxcarcinoom 2007.

6. Nederlandse werkgroep hoofd-halstumoren. Richtlijn mondholte- en orofarynxcarcinoom 2004.

7. Chatuvedi AK, Engels EA, Anderson WF, Gillison ML. Incidence trends for human papilomavirus-related and -unrelated oral squamous cell carcinomas in the United States. J Clin Oncol 2008;26:612-9.

8. Frisch $M$, Hjalgrim H, Jaeger AB, Biggar RJ. Changing patterns of tonsillar squamous cell carcinoma in the United States. Cancer Causes Control 2000;11:489-95.

9. Hyams VJ. Differential diagnosis of neoplasia of the palatine tonsil. Clin Otolaryngol Allied Sci. 1978;3:117-26.

10. Lewin F, Norell SE, Johansson $\mathrm{H}$, et al. Smoking tobacco, oral snuff, and alcohol in the aetiology of squamous cell carcinoma of the head and neck. Cancer 1998;82:1367-75.

11. Forastiere A, Koch W, Trotti A, Sidransky D. Head and neck cancer. N Engl J Med 2001;345:1890900.

12. Johnson N. Tobacco use and oral cancer: a global perspective. J Dent Educ 2001;64:328-39.

13. Chien Y-C, Chen J-Y, Liu M-Y, Yang H-I, Hsu M-M, Chen C-J, Yamg C-S. Serologic markers of Epstein-Barr Virus infection and nasopharyngeal carcinoma in Taiwanese men. New Engl J Med 2001;345:187782.

14. Kreimer AR, Randi G, Herrero R, Castellsague X, La Vecchia C, Franceschi S. Diet and body mass, and oral and oropharyngeal squamous cell carcinomas: analysis from the IARC multinational case-control study. Int J Cancer 2006;118:2293-7.

15. Scully C. Oral squamous cell carcinoma; from an hypothesis about a virus, to concern about possible sexual transmission. Oral Oncol 2002;38:227-34.

16. Koch WM, Lnago M, Sewell D, Zahurak M, Sidransky D. Head and neck cancer in non-smokers: a distinct clinical and molecular entity. Laryngoscope 1999; 109:1544-51.

17. Shope RE, Hurst EW. Infectious papillomatosis of rabbits. J Exp Med 1933;58:607-23.

18. zur Hausen H. Papillomaviruses and cancer: from basic studies to clinical application. Nat Rev Cancer 2002;2:342-50.

19. McKaig RG, Baric RS, Olshan AF. Human papillomavirus and head and neck cancer: epidemiology and molecular biology. Head \& Neck 1998;20:250-65.

20. Andl T, Kahn T, Pfuhl A, Nicola T, Erber R, Conradt C, Klein W, Helbig M, Dietz A, Weidauer H, Bosch FX. Etiological involvement of oncogenic human papillomavirus in tonsillar squamous cell carcinomas lacking retinoblastoma cell cycle control. Cancer Res 1998;58:5-13.

21. Gillison ML, Koch WM, Capone RB, Spafford M, Westra WH, Wu L, Zahurak ML, Daniel RW, Biglione $M$, Symer DE, Shah KV, Sidransky D. Evidence for a causal association between human papillomavirus and a subset of head and neck cancers. J Natl Cancer Inst 2000;92:709-20.

22. Van Houten VM, Snijders PJ, Van den Brekel MW, Kummer JA, Meijer CJLM, van Leeuwen B, Denker F, Smeele LE, Snow GB, Brakenhoff RH. Biological evidence that human papillomaviruses are etiologically involved in a subgroup of head and neck squamous cell carcinomas. Int J Cancer 2001; 93: 232- 5.

23. Hafkamp HC, Speel EJ, Haesevoets A, Bot FJ, Dinjens WNM, Ramaekers FCS, Hopman AHN, Manni JJ. A subset of head and neck squamous cell carcinomas exhibits integration of HPV 16/18 DNA and overexpression of p16INK4A and p53 in the absence of mutations in p53 exons 5- 8. Int J Cancer 2003; 107: 394-400. (Chapter 2). 
65. Strome SE, Savva A, Brissett AE, Gostout BS, Lewis J, Clayton AC, McGovern R, Weaver AL, Persing D, Kasperbauer JL. Squamous cell carcinoma of the tonsils: a molecular analysis of HPV associations. Clin Cancer Res 2002;8:1093-100.

66. Haraf DJ, Nodzenski E, Brachman D, Mick R, Montag A, Graves D, Vokes EE, Weichselbaum RR. Human papilloma virus and p53 in head and neck cancer: clinical correlates and survival. Clin Cancer Res 1996;2:755-62.

67. Lindel K, Beer KT, Laissue J, Griner RH, Aebersold DM. Human papillomavirus positive squamous cell carcinoma of the oropharynx: a radiosensitive subgroup of head and neck carcinoma. Cancer 2001;92:805-13. 


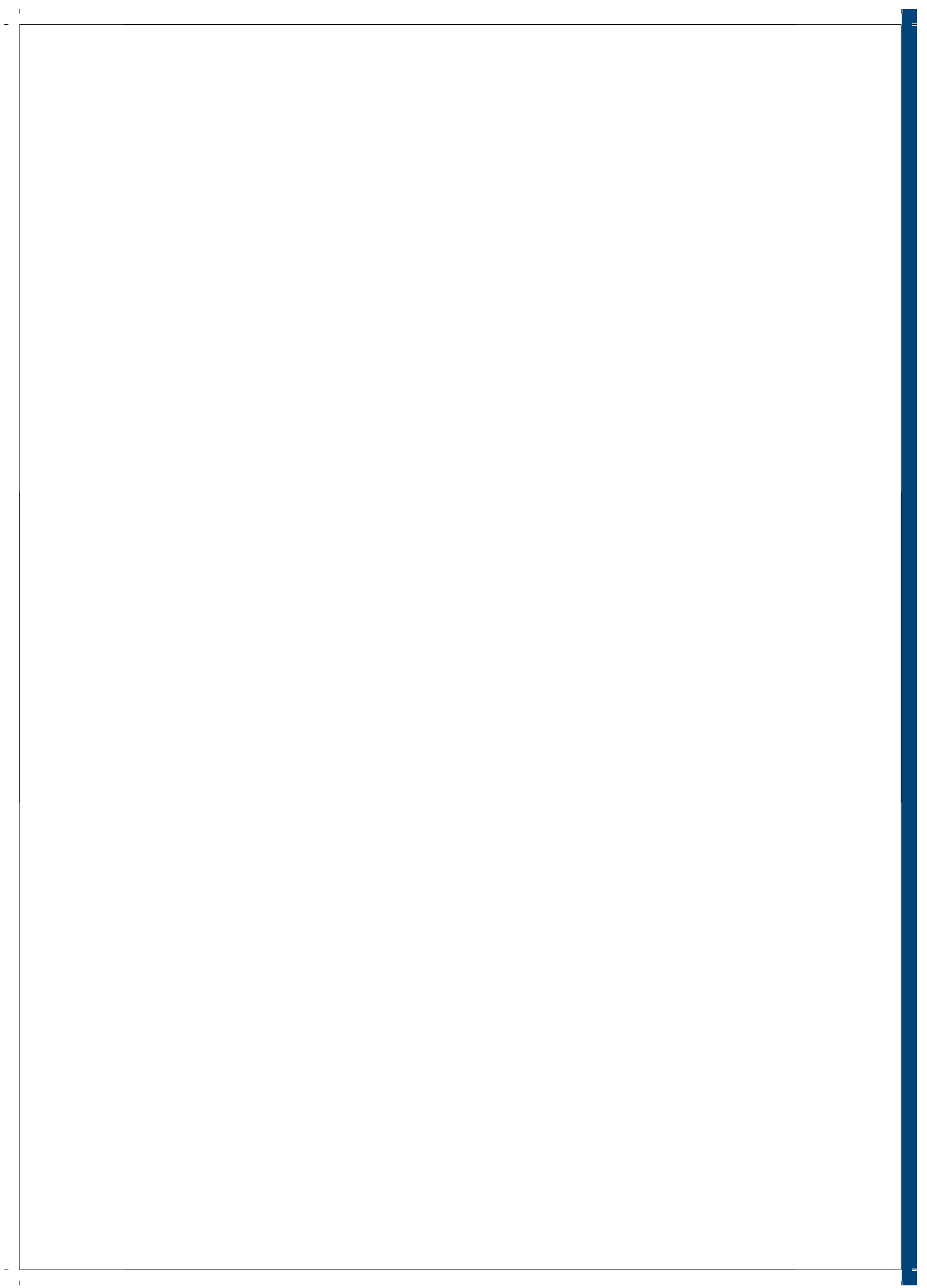




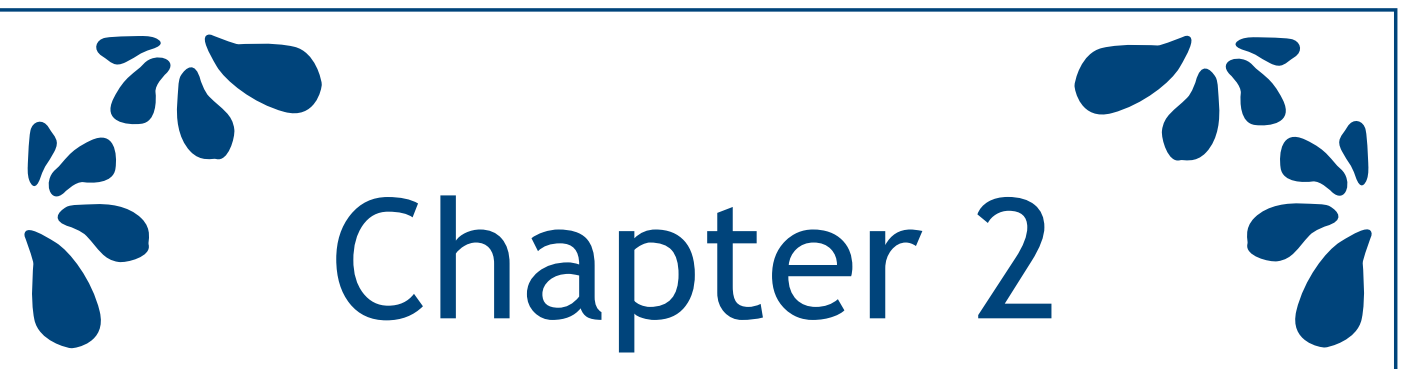

A subset of head and neck squamous cell carcinomas

exhibits integration of hpv 16/18 DNA and overexpression of $\mathrm{p} 16^{\mathrm{INK} 4 \mathrm{~A}}$ and $\mathrm{p} 53$ in the absence of mutations in p53 exons 5-8

Harriët C. Hafkamp, Ernst J.M. Speel, Annick Haesevoets, Fredrik J. Bot, Winand N.M. Dinjens, Frans C.S. Ramaekers, Anton H.N. Hopman, and Johannes J. Manni

International Journal of Cancer 2003; 107, 394-400

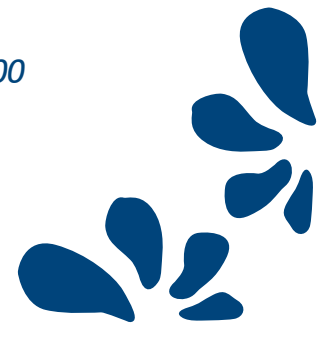




\begin{abstract}
Besides well-known risk factors such as tobacco use and alcohol consumption, oncogenic human papillomavirus (HPV) infection also has recently been suggested to promote head and neck tumorigenesis. HPV is known to cause cancer by inactivation of cell cycle regulators p53 and pRb via expression of viral oncoproteins E6 and E7. This indicates that p53 mutations are not a prerequisite in HPV-induced tumor development. However, discrepancy exists with respect to the frequency of head and neck squamous cell carcinomas (HNSCC) harboring DNA of oncogenic HPV and the fraction of these tumors showing p53 mutations. In our study, we examined the frequency of HNSCC demonstrating HPV 16/18 integration as identified by fluorescence in situ hybridization (FISH) and investigated their p53 (mutation) status by immunohistochemistry and single-strand conformation polymorphism (SSCP) analysis of exons 5-8. Paraffin-embedded, archival biopsy material from 27 premalignant mucosal lesions and 47 cases of HNSCC were analyzed. Ten of the 47 (21\%) HNSCC unequivocally exhibited HPV 16 integration, including 8 of $12(67 \%)$ tonsillar carcinomas. This is supported by the immunohistochemical detection of p16 INK4A overexpression in all 10 HPV-positive tumors. Although FISH is considered to be less sensitive than PCR-based methods for HPV detection, our data clearly demonstrate clonal association of HPV with these tumors, as illustrated by the presence of integrated HPV 16 in both the primary tumor and their metastases in 2 patients. In contrast, HPV 16/18 DNA could not be detected in the premalignant lesions. In 30 of 47 (64\%) HNSCC accumulation of p53 was observed, including 8 of the $10 \mathrm{HPV}$-positive carcinomas. However, in none of the latter cases could mutations in exons 5-8 be identified, except for a polymorphism in codon 213 of exon 6 in one patient. Evaluation of clinical data revealed a significant inverse relation between tobacco use with or without alcohol consumption, and HPV positivity of the tumors.
\end{abstract}




\section{Introduction}

Head and neck squamous cell carcinomas (HNSCC) account for $6.5 \%$ of annual cancer cases worldwide. During the last decades, the incidence of HNSCC has increased in Western Europe. For example, the incidence of cancer of the mouth and pharynx increased from 26.8 to 33.8 per 100,000 from 1985 to $1990^{1,2}$. Recent data suggest that this increase in incidence is especially high in patients younger than 40 years of age $^{3,4}$. Median age at presentation of HNSCC is 60 years, and $66.7 \%$ of the patients are men.

Tobacco smoking, alcohol drinking and betel quid chewing are well-known risk factors in the etiology of HNSCC, responsible for $90 \%$ of the cases ${ }^{5,6}$. The age at smoking initiation appears to be inversely associated with a higher relative risk of developing a carcinoma ${ }^{5,7}$. Tobacco and alcohol use are independent risk factors, but when combined a synergistic effect is observed ${ }^{5}$. In addition, epidemiologic and molecular data suggest that human oncogenic papillomaviruses (HPVs), known to cause cervical and other anogenital cancers, may also promote head and neck carcinogenesis ${ }^{8-10}$. Discrepancy exists with respect to the percentage of HNSCC harboring HPV, as the reported frequencies in head and neck lesions vary over a wide range $(2-76 \%)^{8,11}$. These differences may be due to the detection method used (Southern blot hybridization, polymerase chain reaction (PCR) or in situ hybridization), the anatomic location of tumors, the type of HPV detected and/or the number of tissue samples analyzed in the various studies ${ }^{8,11}$.

Most studies have so far concentrated on the role of HPV in the etiology of uterine cervical cancer ${ }^{12}$. Particularly the high-risk oncogenic HPVs, such as HPV type 16 and 18, induce preneoplastic lesions with an increased risk of progression to cancer. The transition from dysplasia to invasive cancer appears to be associated with integration of the viral DNA into the host genome, most probably at fragile sites in chromosomes ${ }^{13-15}$. Molecular studies have shown that HPV integration results in upregulation of the viral oncoproteins $E 6$ and E7 $7^{8,12}$. The E6 protein contains zinc-binding motifs and can complex with the host cell p53, thereby inducing p53 degradation through the ubiquitin-mediated pathway and thus preventing a cell cycle block and induction of apoptosis in DNA-damaged cells. The E7 protein forms complexes with hypophosphorylated forms of the retinoblastoma tumor suppressor protein (pRb), resulting in a decrease of the cellular pRb level and a release of E2F, a transcription factor involved in cell cycle progression ${ }^{16,17}$. Since HPV inactivates 
both p53 and pRb, it is expected that inactivating mutations in these genes do not play an important role in HPV-infected HNSCC. This is not only the case in cervical cancers ${ }^{10,12}$ but also in half of the HNSCC ${ }^{6}$. Some studies on HNSCC, however, have reported the concomitant presence of HPV DNA and p53 overexpression and/or mutation ${ }^{9,18-21}$. This gives rise to the question as to whether HPV is causally related to the development of a subgroup of HNSCC.

Because HNSCC are thought to arise via a multistep process with histologically distinct precursor phenotypes harboring specific genetic alterations ${ }^{6,22}$, we sought to clarify the relationship between the presence of HPV 16/18 and p53 alterations in premalignant lesions of the head and neck mucosa, HNSCC and their metastases. For this purpose, we have applied fluorescence in situ hybridisation (FISH) combined with tyramide signal amplification to formaldehyde-fixed, paraffin-embedded tissue sections because this sensitive approach enables not only the direct visualization of up to 1 copy of HPV DNA in cells ${ }^{23,24}$ but also allows for the distinction between the integrated or replicative (episomal) state of HPV 16/18 on basis of a punctate or a diffuse hybridization signal, respectively ${ }^{25,26}$. p53 accumulation in cell nuclei was detected by immunohistochemistry, and the HPV-positive tumors were also examined by single-strand conformation polymorphism (SSCP) analyses of p53 exons 5-8 to investigate if p53 accumulation was related to a mutation in the gene. HPVpositive and negative oropharyngeal carcinomas, in addition, were stained for $\mathrm{pRb}$ and $\mathrm{p} 16^{\mathrm{INK} 4 \mathrm{~A}}$ to assess the expression levels of these proteins. Clinical data and alcohol and tobacco intake were related to the presence of HPV in the tumor.

\section{Material and methods}

\section{Tumor material and patient data}

Formaldehyde-fixed, paraffin-embedded archival biopsy and resection material from 74 patients was selected from the archives of the Department of Pathology, University Hospital Maastricht, The Netherlands. These included 27 patients with premalignant mucosal lesions and 47 patients ( 13 female, 34 male; mean age at diagnosis, 57 [range, 27-84] years) with primary HNSCC and 9 metastases corresponding to these primary carcinomas. The distribution by anatomic site was as follows: premalignant lesions: 21 were located in the larynx and 6 in the oral cavity (7 hyperplasia, 10 mild dysplasia, 7 moderate dysplasia and 3 severe dysplasia); HNSCC: 7 were located 
in the larynx, 19 in the oral cavity (10 tongue, 4 palate, 3 floor of the mouth, 2 alveolar process), 16 in the oropharynx (12 tonsil, 4 base of the tongue) and 5 in the hypopharynx. Demographic data, including age at diagnosis, gender, alcohol and tobacco exposures, were obtained from medical records. Tumor site, grade and PTNM classification were determined from review of pathologic, radiologic and surgical reports ${ }^{27}$.

A series of $4 \mu \mathrm{m}$-thick sections were cut from the specimens for (i) hematoxylineosin staining and detailed histopathologic classification (F.J.B.) ${ }^{27}$, including determination of the absence or presence of basaloid features ${ }^{9}$; (ii) FISH to detect HPV 16/18; (iii) immunohistochemistry to visualize p53, pRb and p16 ${ }^{\text {INK4A }}$ expression; (iv) extraction of genomic DNA to be analyzed by SSCP for $\mathrm{p} 53$ gene mutations.

\section{Detection of HPV 16/18 DNA by FISH}

FISH was performed on $4-\mu \mathrm{m}$ tissue sections as described previously 22,28 . Formaldehyde-fixed, paraffin-embedded sections were deparaffinized, pretreated with $85 \%$ formic acid $/ 0.3 \% \mathrm{H}_{2} \mathrm{O}_{2}$ for 20 min at room temperature and subsequently dehydrated with $70 \%$ ethanol containing $0.01 \mathrm{M} \mathrm{HCl}$ (acid dehydration), 90\% ethanol and $100 \%$ ethanol for $3 \mathrm{~min}$ each prior to air drying. The slides were incubated in $1 \mathrm{M} \mathrm{NaSCN}$ for $10 \mathrm{~min}$ at $80^{\circ} \mathrm{C}$, followed by acid dehydration and digestion with 4 $\mathrm{mg} / \mathrm{ml}$ pepsin (800-1,200 U/mg protein from porcine stomach mucosa; Sigma, St. Louis, MO) in $0.02 \mathrm{M} \mathrm{HCl}$. The slides were rinsed 3 times in $0.01 \mathrm{M} \mathrm{HCl}$ and acid dehydrated. After air drying, sections were postfixed in $1 \%$ formaldehyde in PBS for $15 \mathrm{~min}$ at room temperature and dehydrated in an ascending ethanol series. The digoxigeninlabeled HPV 16, 18 and HPV 16/18 mixture probes (Kreatech, Amsterdam, The Netherlands) were applied under a coverslip according to the manufacturer's instructions. Probe and target DNA were denatured simultaneously for 5 min at $80^{\circ} \mathrm{C}$ prior to hybridization overnight at $37^{\circ} \mathrm{C}$ in a humid chamber. After hybridization the preparations were washed stringently in $50 \%$ formamide, $2 \times S S C$ at $42^{\circ} \mathrm{C}(2$ times 5 $\mathrm{min})$. The digoxigenin-labeled probes were detected conventionally by application of mouse anti-digoxin (Sigma), rhodamin-conjugated rabbit anti-mouse IgG and rhodamin-conjugated swine anti-rabbit lgG or by using tyramide signal amplification (TSA) as previously described 29,30 . In short, the digoxigenin-labeled probe was detected with peroxidaseconjugated sheep anti-digoxigenin Fab fragments (Roche, Basel, Switzerland; $1: 100$ diluted in $4 \times$ SSC containing $5 \%$ nonfat dry milk), followed by a TSA reaction using rhodamin-labeled tyramide. Fifty microliters of rhodamin- 
labeled tyramide (1:500 diluted from a $1 \mathrm{mg} / \mathrm{ml}$ stock solution in ethanol) in PBS containing $0.1 \mathrm{M}$ imidazole, $\mathrm{pH} 7.6$, and $0.001 \% \mathrm{H}_{2} \mathrm{O}_{2}$ were applied under a coverslip for $10 \mathrm{~min}$ at $37^{\circ} \mathrm{C}$. Finally, the slides were washed in PBS containing $0.05 \%$ Tween20 (Janssen Chimica, Beerse, Belgium), dehydrated in an ascending ethanol series and mounted in Vectashield (Vector Laboratories, Burlingame, CA) containing 4',6-diamidino-2-phenyl indole (DAPI; Sigma: $0.2 \mu \mathrm{g} / \mathrm{ml}$ ). Microscope images were recorded with the Metasystems Image Pro System (black and white CCD camera; Sandhausen, Germany) mounted on top of a Leica DM-RE fluorescence microscope equipped with DAPI and rhodamin filters.

\section{Controls and evaluation of FISH results}

Controls included hybridizations on $70 \%$ ethanol suspensions and formaldehydefixed, paraffin-embedded sections of known HPV 16- and 18-positive human cervical carcinoma cell lines (CaSki [ATCC; CRL1550; 500 integrated HPV 16 copies], HeLa [ATCC; CCL2; 20-50 integrated HPV 18 copies] and SiHa [ATCC; HTB35; 1-2 integrated HPV 16 copies]) to guarantee probe specificity, sensitivity and interpretation accuracy ${ }^{23,29}$, as well as hybridizations on tissue sections of cervical lesions with proven integration or episomal presence (replication) of HPV genomic DNA. Negative controls consisted of HPV PCR- and FISH-negative cell lines and tissue sections and hybridizations omitting the viral probe. Evaluation of nuclear hybridization signals was performed by 3 investigators (H.C.H, E.J.M.S. and A.H.) according to the criteria described by Cooper et al. ${ }^{25}$, i.e., punctuate and/or diffuse signals throughout the nucleus indicating integrated and episomal HPV DNA, respectively. In addition, the number of HPV integration spots per nucleus was scored in the tissue.

\section{Immunohistochemical staining of p53, pRb and p16 INK4A}

Immunohistochemical protein staining on $4 \mu \mathrm{m}$-thick formaldehyde- fixed, paraffinembedded tissue sections was performed as described earlier ${ }^{27}$. Briefly, sections were deparaffinized and subsequently pretreated with $0.3 \% \mathrm{H}_{2} \mathrm{O}_{2}$ in methanol to quench endogenous peroxidase activity. Antigen retrieval was performed by microwave heating in $0.01 \mathrm{M}$ citrate buffer ( $\mathrm{pH}$ 6.0). The monoclonal antibodies DO-7 (Dako A/S, Glostrup, Denmark), NCl-Rb (Novocastra, Newcastle upon Tyne, UK) and E6H4 (Dako A/S) were used to detect p53, pRb and p16 ${ }^{\text {INK4A }}$ proteins, respectively. After incubation with a biotinylated secondary antibody, immunohistochemical detection was performed by an avidin-biotinylated peroxidase complex (ABC) 
procedure (Vectastain-Elite-ABC kit; Vector). Peroxidase activity was detected using diaminobenzidine/ $\mathrm{H}_{2} \mathrm{O}_{2}$. Sections were counterstained with hematoxylin and mounted in Entellan (Merck, Darmstadt, Germany). In each analysis, negative and positive controls were included. Analysis was performed by 3 independent observers (H.C.H., E.J.M.S. and A.H.) and consensus was acquired.

Although the DO-7 antibody binds to both normal and mutant p53 protein, in general normal levels of wild-type p53 protein are too low to detect by immunohistochemistry. The number of cells exhibiting a strong, positive nuclear p53 staining was scored as: (i) negative when $<30 \%$ of the cells exhibited a nuclear staining; (ii) positive when $\geq 30 \%$ of the cells exhibited a nuclear staining ${ }^{31}$. pRb nuclear staining in normal squamous epithelium is abundant and includes parabasal and the lower suprabasal layers (high intensity was semiquantitatively scored as 2+ or $3+$ ). Staining in $\geq 30 \%$ of the tumor cell nuclei was scored accordingly or as weaker staining $( \pm$ or +$)$ or absence of staining $(-)^{32}$. Normal expression levels of p16INK4A in squamous epithelium are under the detection limit of immunohistochemistry. Strong nuclear and cytoplasmic p16 1 INK4A $^{\mathrm{A}}$ staining in $\geq 30 \%$ of tumor cells was considered positive and in $<30 \%$ of cells negative ${ }^{33}$.

\section{SSCP and mutation analysis of p53 exons 5-8}

SSCP analysis of exons 5-8 of the p53 gene was performed in 9 of the 10 tumors that were positive for HPV $16 / 18$ DNA by FISH. Five to ten $10 \mu \mathrm{m}$-thick sections were stained with hematoxylin and eosin to select parts of the tissues composed of $>70 \%$ tumor cells. These areas were microdissected by scraping the tissue from the histologic glass slides. Genomic DNA was extracted according to the tissue protocol of the QIAamp DNA mini kit using proteinase K (Qiagen, Westburg, Leusden, The Netherlands). Exons 5-8 of the p53 gene were investigated by PCR SSCP analysis as previously described ${ }^{34}$. In short, each exon was amplified in 2 overlapping fragments and tumor DNA was always compared with normal DNA from the same patient. PCR was performed with $30 \mathrm{ng}$ isolated DNA in a final reaction volume of $15 \mu \mathrm{l}$ containing: $1.5 \mathrm{mM} \mathrm{MgCl}, 0.02 \mathrm{mM}$ dATP, $0.2 \mathrm{mM}$ dGTP, dTTP and dCTP each, $0.8 \mu \mathrm{Ci} a-32$ PdATP (Amersham, Buckinghamshire, UK), 20 pmol of each primer and 0.2 unit Taq polymerase (Promega, Madison, WI). PCR was performed for 35 cycles (denaturing at $95^{\circ} \mathrm{C}$ for $30 \mathrm{sec}$, annealing at $55^{\circ} \mathrm{C}$ for $45 \mathrm{sec}$ and extension at $72^{\circ} \mathrm{C}$ for $1 \mathrm{~min}$ ) in a Biometra thermocycler (Biometra, Göttingen, Germany). A final extension was carried out at $72^{\circ} \mathrm{C}$ for $10 \mathrm{~min}$. PCR products were diluted with loading buffer (95\% 
formamide, $10 \mathrm{mM}$ EDTA ( $\mathrm{pH} 8.0$ ), $0.025 \%$ bromophenol blue and $0.025 \%$ xylene cyanol), denatured at $95^{\circ} \mathrm{C}$ for $4 \mathrm{~min}$ and snap-cooled on ice. The samples were run overnight at $7 \mathrm{~W}$ on a nondenaturing $6 \%$ polyacrylamide gel containing $10 \%$ glycerol in $1 \times$ TBE running buffer. After electrophoresis, gels were fixed in $10 \%$ acetic acid, dried on blotting paper on a vacuum gel dryer and exposed to X-ray film overnight at $-70^{\circ} \mathrm{C}$, using intensifying screens. Films were evaluated by visual inspection. The aberrant band from the PCR-SSCP analysis of the single HPV-positive tongue tumor (tumor 1 in Table 1) was excised from an additionally prepared Sybr Green-stained SSCP polyacrylamide gel, reamplified, purified using a QIAquick gel extraction kit (Qiagen) and sequenced by cycle sequencing as described previously 35 .

\section{Statistical analysis}

Factors associated with HPV status were selected on cross-tabulations, which were analyzed by the use of the Fisher exact test (2-tailed) and/or $\mathrm{X}^{2}$ test. A significance level of $p \leq 0.05$ was chosen.

\section{Results}

\section{Presence of HPV 16/18 DNA in cell lines}

To examine the sensitivity and reliability of our protocols, the Siha, Hela and Caski cell lines were subjected to FISH using the HPV 16- and 18-specific probes, followed by conventional or TSA detection procedures. Figure 1a-d shows that our FISH procedures on $70 \%$ ethanol fixed and pepsin-pretreated cell suspensions enable the detection of all 5 HPV 18 integration sites in Hela cells (integrated at 8q24) as well as the 1-2 HPV 16 integration sites in Siha cells (integrated at 13q21) by both detection methods. This could also be achieved by hybridization to paraffin sections of these cell lines (data not shown). As the TSA procedure allows evaluation at lower magnification due to its higher sensitivity, we have used this system to further analyze the series of head and neck lesions.

\section{Presence of HPV 16/18 DNA in premalignant lesions and HNSCC}

In total, 27 premalignant mucosal lesions, 47 primary carcinomas and 9 corresponding metastases were examined for the presence of HPV 16 and 18 DNA by FISH. In none of the tested premalignant lesions could HPV $16 / 18$ be identified by our FISH procedure. 
Ten of the 47 (21\%) HNSCC exhibited HPV 16- specific FISH signals (Table 1) and only in case no. 8 a simultaneous infection with HPV 18 was observed. Interestingly, these $10 \mathrm{HNSCC}$ comprised only 1 nonoropharyngeal tumor (tongue carcinoma) and 9 of the 16 oropharyngeal carcinomas (56\%), i.e., 8 tonsillar and 1 base of the tongue tumors, indicating a highly significant $(p<0.001)$ correlation between HPV positivity and localization in the oropharynx. The $10 \mathrm{HPV}$-positive tumors all harbored punctate FISH patterns indicating HPV integration (Figure 1e,f and Table 1), while 7 of these tumors showed evidence for a concomitant replication of the virus in specific areas of the tumor (Figure 1g). Seven of the $10 \mathrm{HPV}$-positive tumors showed $1 \mathrm{HPV}$ integration site per nucleus (Figure 1e), 2 tumors harbored areas with more than 1 integration site per nucleus (Figure 1f) and 1 tumor showed both a large and a smaller hybridization spot in the nuclei, suggesting different copy numbers of virus integrated at 2 sites in the cellular genome (case number 2, Table 1). Only in 2 of the $10 \mathrm{HPV}$-positive tumors did all tumor cells contain the viral DNA (tumor numbers 1 and 3, Table 1), whereas in the other 8 cases the HPV DNA-containing cells were either present as clusters or scattered throughout the tumor. From 2 patients, of which lymph node metastases were available for analysis, both the metastasis as well as the primary tumor displayed identical punctate nuclear HPV 16 signals, indicating stable integration of the virus prior to and during tumor spread (tumor numbers 3 and 4, Table 1 and Figure $1 \mathrm{~h}-\mathrm{k}$ ).

\section{Correlation between HPV 16 integration and absence of p53 mutations in exons 5-8}

Fifteen of the 27 premalignant lesions (55\%) showed accumulation of p53, predominantly observed in the basal cell layers of the epithelium (data not shown). In 30 of the 47 HNSCC (64\%) p53 overexpression was detected, including 8 of the 10 HPV-positive carcinomas (Tables 1 and 2, and Figure 2a,b). To verify whether p53 accumulation in the HPV-positive HNSSC correlates with the presence of a gene mutation, 9 of the 10 tumors were also examined by SSCP analysis of p53 exons 5-8 (Figure 1l). Only the analysis of tumor DNA from patient number 1 (Table 1) resulted in a gel shift from a polymorphism in codon 213 of exon 6 of the p53 gene, also detected in the control DNA of the patient (Figure 1l-n). Thus, in our study no p53 mutations could be identified in HPVpositive HNSCC, despite the fact that these tumors often accumulate wild-type p53. 


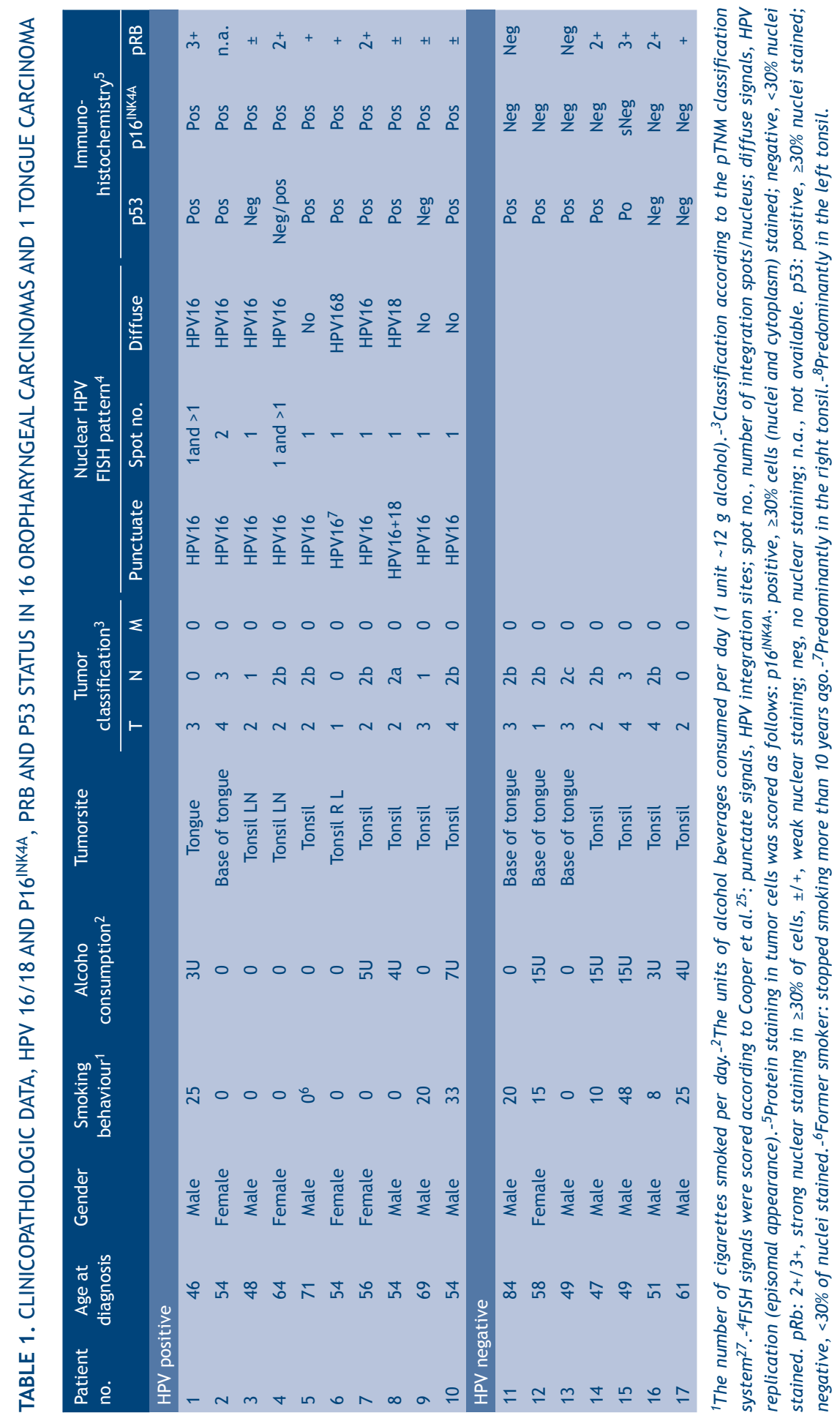



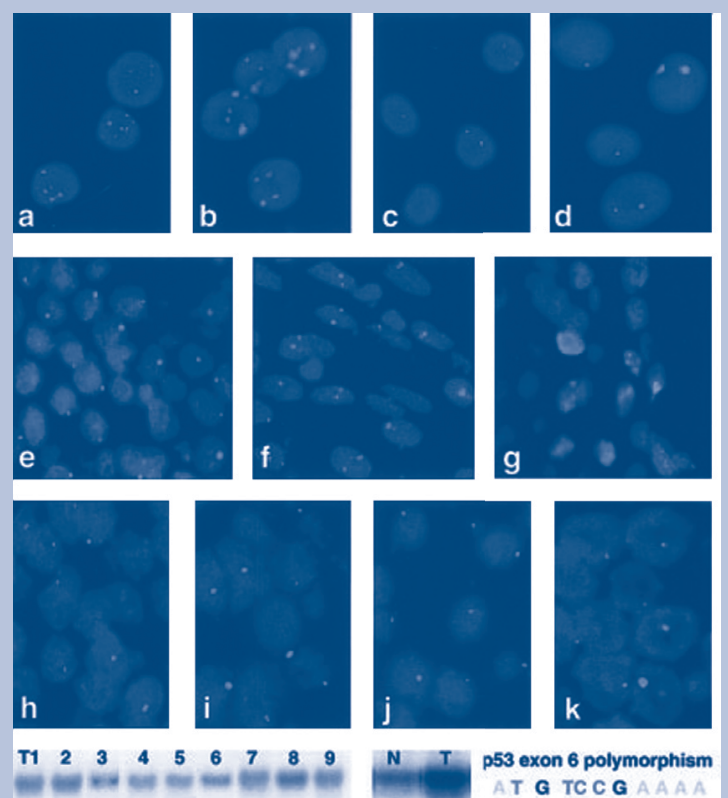

N T $p 53$ exon 6 polymorphism
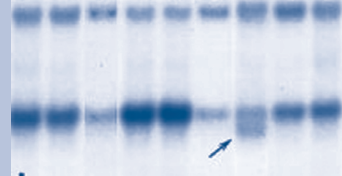

I

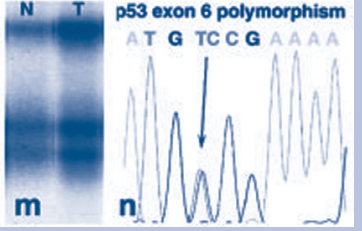

FIGURE 1. (a-k) RESULTS OF HPV 16/18 FISH ANALYSIS AND (l-n) SSCP ANALYSIS OF CELL LINES (a-d), TISSUE SECTIONS (e-k) AND EXTRACTED GENOMIC DNA (l-n) FROM SQUAMOUS CELL CARCINOMAS OF THE CERVIX (a- d) AND HEAD AND NECK REGION (e-n). (a,b) Hela cell nuclei (dark) showing the expected $5 \mathrm{HPV} 18$ integration sites (punctate signals, light) as visualized by conventional (a) and TSA (b) probe detection. (c,d) SiHa cell nuclei (dark) showing the expected 1-2 HPV 16 integration sites (punctate signals, light) as visualized by conventional (c) and TSA (d) detection. (e-g) Example of HPV 16-positive tongue carcinoma (patient no. 1, Table 1) showing different tumor areas harboring nuclei (dark) with 1 integration site (e), 2 integration sites (f) and episomal appearance of the virus (g) (light punctate $(e, f)$ and diffuse $(g)$ signals, respectively). (h- k) Primary tonsillar carcinoma and corresponding metastasis of patient nos. $3(h, i)$ and $4(j, k)$ demonstrating clonal association of HPV 16 during tumor spread as 1 integration site (light) per nucleus (dark). (l-n) p53 exon 6 II PCR-SSCP results of 9 of the $10 \mathrm{HPV}$-positive HNSCC patients. (l) Lanes 1-9 correspond to patient nos. 9, 5, 4, 6, 8, 3, 1, 7 and 2 in Table 1, respectively. The arrow indicates an aberrantly migrating fragment in tumor $1 .(\mathrm{m})$ Comparison of tumor and normal DNA from patient 1 showing the aberrant fragment in both tissue samples. (n) Identification of an exon 6 codon 213 polymorphism (arrow) after sequencing the exon 6 II PCR products of tumor 1. (see page 152 for color figure) 

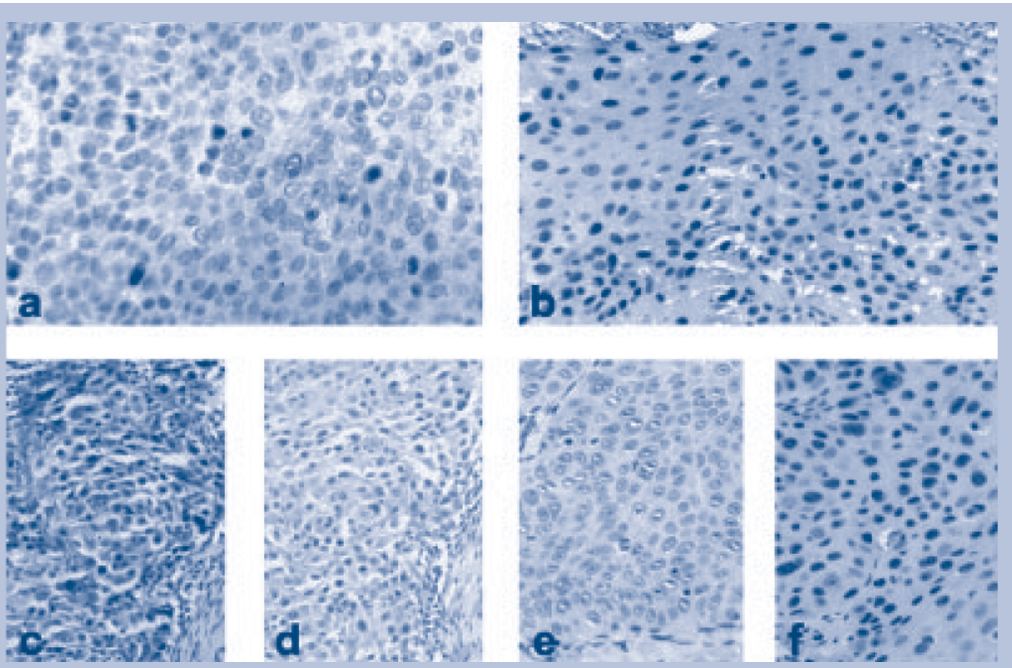

FIGURE 2. IMMUNOHISTOCHEMICAL STAINING FOR P53 (a,b), P16INK4A (c,e) AND PRB (d,f). (a,b) HPV-positive HNSCC no. 4 (a) and 1 (b) (Table 1) showing distinct nuclear staining for p53 protein in $<30 \%$ and $100 \%$ of tumor cells. (c,d) HPV-positive tonsillar carcinoma no. 8 (Table 1) showing strong nuclear and cytoplasmic staining for $\mathrm{p} 16^{\mathrm{INK} 4 \mathrm{~A}}$ (c) but only weak nuclear staining for $\mathrm{pRb}$ (d) in the tumor cells. (e,f) HPV-negative tonsillar carcinoma no. 15 showing no p16 ${ }^{\text {INK4A }}$ staining (e) but strong nuclear pRb staining in the tumor cells (f). (see page 153 for color figure)

\section{Correlation between HPV status and p16 $16^{\mathrm{NK} 4 \mathrm{~A}}$ overexpression}

To assess the level of pRb and p16 ${ }^{\mathrm{INK} 4 \mathrm{~A}}$ expression in HNSCC associated with HPV, immunohistochemical staining was performed on tissue sections of the 17 tumors listed in Table 1. Representative examples are presented in Figure 2c-f. A remarkable correlation was found between $16^{\text {INK4A }}$ accumulation and the presence of HPV because all $10 \mathrm{HPV}$-positive HNSCC exhibited strong nuclear and cytoplasmic staining in the tumor areas harboring cells with integrated HPV (Figure 2c), while the HPV-

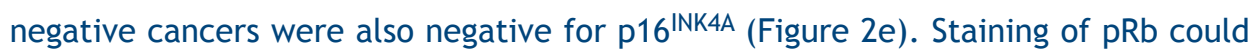
be performed in 16/17 tumors and intense nuclear staining was observed in 3/9 $\mathrm{HPV}$-positive and 3/7 HPV-negative tumors (in total 37\%; Figure 2f). Accordingly, in $63 \%$ of carcinomas pRb expression was reduced or negative, including 6 of $9 \mathrm{HPV}$ positive cases (Table 1 and Figure $2 \mathrm{~d}$ ). These data are in agreement with the results of Wiest et al. ${ }^{32}$ and demonstrate that besides a wild-type p53 status HPV-positive HNSCC are characterized by $\mathrm{p} 16^{\mathrm{INK} 4 \mathrm{~A}}$ overexpression, as well as reduced pRb levels in most cases. 
TABLE 2. HPV 16 AND P53 STATUS ACCORDING TO PRIMARY TUMOR SITE.

\begin{tabular}{|c|c|c|c|c|}
\hline & \multicolumn{2}{|c|}{ p53 + 1} & \multicolumn{2}{|c|}{ p53 - } \\
\hline & HPV + & HPV - & HPV + & HPV - \\
\hline Oral cavity $(n=19)$ & 1 & 10 & & 8 \\
\hline Oropharynx $(n=16)$ & 7 & 5 & 2 & 2 \\
\hline Hypopharynx $(n=5)$ & & 4 & & 1 \\
\hline Larynx $(\mathrm{n}=7)$ & & 3 & & 4 \\
\hline Total $(n=47)$ & 8 & 22 & 2 & 15 \\
\hline
\end{tabular}

${ }^{1} p 53$ accumulation in $\geq 30 \%$ of tumor cell nuclei.

\section{Correlation between HPV status, clinicopathologic parameters and risk factors}

Clinical data, including gender, age at diagnosis and pTNM-classification of all oropharyngeal tumors and 1 tongue carcinoma as well as alcohol and tobacco consumption data are listed in Table 1. The mean age of patients with HPV-positive tumors was identical to that of patients with HPV-negative tumors, i.e., 57 years. In addition, neither PTNM-classification nor tumor grade (data not shown) was correlated with HPV 16/18 status. Four HPV-positive tumors showed basaloid characteristics (i.e., case numbers. 3, 7, 8 and 9 in Table 1). Four of the 9 HPV-positive patients with an oropharyngeal carcinoma (44\%) were alcohol and/or tobacco consumers. This is in contrast to the HPV-negative patients, where 6 of the $7(86 \%)$ patients consumed tobacco and 5 of the 7 (71\%) consumed both tobacco and alcohol. Statistical analysis showed a significant correlation between HPV presence and the absence of tobacco exposure, i.e., 7 of 9 patients with HPV-positive tumors were nonsmokers compared to 1 of 7 patients who presented with an HPV-negative tumor ( $p=0.0406)$. This also holds true when comparing HPV presence with consumption of both cigarettes and alcohol ( 1 of 9 patients with HPV-harboring tumors vs. 5 of 7 with HPV-negative cancers; $p=0.0350$ ). In contrast, there was no clear relation between HPV status and alcohol consumption alone or in combination with tobacco intake. 


\section{Discussion}

Similar to the situation in the uterine cervix, where oncogenic HPV has been firmly established as an etiologic risk factor for the development of squamous cell carcinoma and adenocarcinoma ${ }^{12}$, several molecular and epidemiologic studies suggest that HPV also plays a role in the carcinogenesis of the head and neck mucosa in a subset of patients ${ }^{8-10,32,36}$. In conjunction with these suggestions, our data provide strong evidence that HPV 16 integration into the tumor cell genome is linked to a defined subset of HNSCC, particularly oropharyngeal carcinomas. These cancers, which exhibited $\mathrm{p} 16^{\mathrm{INK} 4 \mathrm{~A}}$ overexpression but no $\mathrm{p} 53$ mutations in exons $5-8$, may comprise a distinct pathologic entity, predominantly occurring in patients without a history of extravagant tobacco and/or alcohol consumption.

Although the prevalence of HPV in lesions of the head and neck mucosa has already been suggested by the end of the $1980 \mathrm{~s}^{37}$, the use of different detection methods and HPV-specific probes, as well as varying numbers of tissue samples of different locations, has caused confusion with respect to the frequency of HPVpositive lesions, ranging from $2-76 \% 8,11$. Especially the transition in the 1990 s from in situ hybridization techniques to the highly sensitive PCR procedures to detect HPV DNA and its transcripts has actually decreased the discriminative power of HPV detection. For example, almost every lesion of the uterine cervix tested by these sensitive protocols will be classified HPV-positive ${ }^{38}$. Such an outcome will only be meaningful when evidence for the biologic association of HPV with the tumor cells is provided. This can, for example, be achieved by determining the viral copy number, E6/E7 expression levels or replication and/or integration state, the latter being linked to malignant progression in uterine cervical lesions ${ }^{10,15,25,32,33,36}$. This additional information can be generated by molecular approaches such as Southern blotting, (quantitative) (RT)PCR analysis of (microdissected) tumor cells and/or FISH. In our study, we have applied a highly sensitive FISH procedure enabling both HPV DNA detection up to the level of a single copy per cell nucleus, as well as discrimination between replicative (episomal) and integrated virus on the basis of the nuclear staining pattern. Our data show that $56 \%$ of oropharyngeal carcinomas, in particular tonsillar tumors (67\%), exhibit HPV 16/18 genomic DNA integration in comparison to $3 \%$ of nonoropharyngeal carcinomas $(p=0.001$ ) (in total $21 \%$ of HNSCC). HPV integration was predominantly seen as 1 punctate FISH signal per tumor nucleus. The strong association of HPV 16 with oropharyngeal cancer is in agreement 
with recent data in the literature generated by PCR-based techniques 8 -10,32,36,39 and further underlines the sensitivity of our FISH protocol. Nevertheless, a slight underestimation of HPV-infected HNSCC cannot be ruled out because we only focused on HPV types 16 and 18. In 2 patients where tissue from a lymph node metastasis was available, HPV integration could be identified in both the primary tumor and the metastasis, suggesting a clonal association of HPV with tumor cells. Besides HPV DNA integration, 7 of $10 \mathrm{HPV}$-positive HNSCC also harboured scattered (groups of) tumor cells with diffuse FISH signals, indicating replicative, extrachromosomal HPV. This finding is in agreement with in situ HPV staining results obtained in squamous cell carcinomas of the uterine cervix ${ }^{25}$.

It has been proposed that transition of oncogenic HPV DNA from the replicative to the integrated state may reflect a progression towards the malignant phenotype in uterine cervical lesions ${ }^{15,25}$. If this hypothesis also holds for head and neck mucosal lesions, one would expect predominantly diffuse HPV staining patterns in preinvasive mucosal lesions. However, in our study we were unable to detect HPV 16/18 DNA in all these premalignant cases. This may be explained by the fact that in all cases it concerned preinvasive, nonoropharyngeal lesions (larynx, oral cavity). Although HPV has been reported to be present in these lesions, this mostly concerned HPV types 6 and 11, viruses that are considered of low oncogenic potential. Because premalignant lesions of the tonsils are scarcely observed in the clinic, studies on the prevalence of HPV 16/18 in normal mucosa of tonsils of healthy persons as well as tonsils with carcinomas, e.g., by using cytologic cell scrapes ${ }^{40}$, should shed further light on its role in promoting tonsillar carcinogenesis. Alternatively, one could search for HPV-positive cells in premalignant lesions present in resection margins of operated tonsillar carcinomas. As it has been suggested that HPV-positive tonsillar carcinomas are a sexually transmitted disease ${ }^{9,39}$, further epidemiologic studies should determine HPV prevalence in tonsils of the healthy population in relation to sexual behavior ${ }^{36}$.

Our findings indicate that within the oropharynx in particular the palatine tonsils are at risk for HPV infection. Why particularly the tonsils are susceptible to HPV infection is unclear to date. Explanations to be considered comprise the fact that (i) tonsils, like the uterine cervix, are easily accessible and appear to undergo metaplastic processes ${ }^{41}$; (ii) tonsils contain deep invaginations of the mucosal surface (crypts), creating an extensive monolayered epithelial surface that may facilitate viral access to basal cells and intensive antigenic stimulation ${ }^{36,42}$; (iii) the presence 
of cytokines produced by lymphoid tissue may affect HPV transcription and cellular transformation ${ }^{41,43}$.

We noticed that all 9 HPV-positive HNSCC analyzed by PCR-SSCP for exons 5-8 of the p53 gene were devoid of mutations. This finding is in accordance with previous studies reporting an inverse relationship between p53 mutations and the presence of $\mathrm{HPV} 9,10,32$, and underlines the etiologic role of $\mathrm{HPV}$ in a subset of HNSCC. HPV integration may thus stimulate tumor progression by targeting the nonmutated p53 for ubiquitination and degradation via E6 oncoprotein. This inactivation of p53 is achieved in half of the HNSCC by the mutation of the protein ${ }^{6}$. The literature reports large discrepancies in the number of HPV-PCR-positive HNSCC exhibiting simultaneous p53 exon 5-8 mutations, ranging from 13-46\%9,10,18,19,21,32,44. In 2 of these studies ${ }^{10,32}$, it was observed that when also taking E6 expression into account as an additional indicator of a causal relationship between HPV and HNSCC, maximally $8 \%$ of the tumors harbored p 53 mutations. In addition, part of these tumors exhibited downregulation of $\mathrm{pRb}$ and accumulation of $\mathrm{p} 16^{\mathrm{INK} 4 \mathrm{~A}}$ further indicating that in these carcinomas HPV is indeed etiologically involved. This implies that the high sensitivity of HPV detection by PCR also identifies "biologically irrelevant" cases due to the presence of only a few viral genomes that may not be clonally associated with the tumor or the use of crude extracts of frozen or paraffin sections with HPV contamination. Therefore, multiple PCR approaches are recommended to unequivocally prove the causal involvement of HPV in HNSCC. It is tempting to speculate that our sensitive FISH approach for assessing the involvement of HPV in HNSCC might be the optimal substitute for those multiple PCR assays. In particular, this approach can link HPV integration into the cellular genome directly to the histologic context. Although we are aware of the fact that we may underestimate the real number of tumors associated with HPV because of the use of only the HPV 16/18-specific probe mixture in our study, the clear correlation between HPV 16 integration as identified by FISH and p16 ${ }^{\mathrm{INK} 4 \mathrm{~A}}$ overexpression (with simultaneous pRb downregulation in 6 of 9 cases) in our study underlines this speculation.

Despite the lack of p53 mutations, 8 of $10 \mathrm{FISH}$-positive HNSCC unexpectedly presented with nuclear accumulation of $\mathrm{p} 53$ in $>30 \%$ of the tumor cells. This apparent discrepancy between p53 overexpression and absence of p53 exon 5-8 mutations has been observed previously ${ }^{18,19,31}$. The molecular mechanisms that may underlie this stabilization and/or overexpression of p53 protein are yet to be identified. Possible explanations comprise (i) the presence of mutations occurring outside exons $5-845$; 
(ii) upregulation of the wild-type p53 protein by genotoxic insults, e.g., ultraviolet radiation or hypoxia ${ }^{46}$; (iii) nonmutational p53 stabilization by $\mathrm{mdm} 2^{47}$ or viral proteins such as large T-cell antigen of SV40; and/or (iv) the lack of functional E6 expression ${ }^{18}$. We are currently in the process of studying some of these hypotheses in our series of HNSCC. Preliminary results so far did not demonstrate clear-cut evidence for transcriptional activity of $\mathrm{p} 53$ as concluded from the fact that the expression levels of the p53 transcriptional targets p21 and mdm2 do not show a consistent correlation with p53 overexpression in the HPV-associated tumors.

Our data show a significant correlation between HPV integration on the one hand and strongly reduced or absent exposure to the known risk factors of HNSCC, i.e., tobacco and alcohol consumption, on the other. These observations provide further evidence for the suggestion that HPV-positive HNSCC represent a separate tumor entity ${ }^{9}, 36$. In these studies, a correlation with less alcohol intake was, however, more significant than with smoking, whereas in our study HPV integration was more strongly associated with smoking alone or in combination with alcohol intake. The reason for these differences may be due to the more accurate determination of HPV integration by FISH than by PCR, or on the other hand the relative low number of HPV-positive HNSCC in our study in comparison with others ${ }^{9}$. An improved prognosis, as has been reported for patients with HPV-positive HNSCC ${ }^{9,48}$, could not be confirmed in our study because of insufficient follow-up. Although our study shows no correlation of HPV status with tumor grading, 4 oropharyngeal carcinomas exhibited a basaloid morphology, which previously has been reported to be associated with HPV positivity ${ }^{9}$. Speculations that HPV-positive tumors might be associated with younger age of patients ${ }^{49}$, tumor size and gender could neither be substantiated in the current study, nor by earlier investigations ${ }^{9,36}$.

From our study we conclude (i) that a subset of HNSCC, particularly tonsillar carcinomas, harbors HPV 16 shown by a sensitive FISH approach to be integrated in the tumor genome; (ii) that this subset of tumors is characterized by p $16^{\text {INK } 4 \mathrm{~A}}$ accumulation, as well as reduced pRb and overexpressed wild-type p53 in most of these cases; and (iii) that these tumors develop in patients showing no extravagant tobacco and/or alcohol consumption. 


\section{Acknowledgements}

The authors thank Ms. S.M.H. Claessen and Ms. M. Schepers (Department of Molecular Cell Biology, University of Maastricht) and Mr. H.F. Sleddens (Department of Pathology, Erasmus University Medical Center Rotterdam) for outstanding technical support. 


\section{References}

1. Parkin DM, Pisani P, Ferlay J. Estimates of the worldwide incidence of twenty-five major cancers in 1990. Int J Cancer 1999;80:827- 41.

2. Parkin DM, Pisani P, Ferlay J. Estimates of the worldwide incidence of eighteen major cancers in 1985. Int J Cancer 1993;54:594-606.

3. Myers JN, Elkins T, Roberts D, Byers RM. Squamous cell carcinoma of the tongue in young adults: increasing incidence and factors that predict treatment outcomes. Otolaryngol Head Neck Surg 2000;122: 44-51.

4. Atula S, Grenman R, Laippala P, Syrjanen S. Cancer of the tongue in patients younger than 40 years. A distinct entity? Arch Otolaryngol Head Neck Surg 1996;122:1313-9.

5. Lewin F, Norell SE, Johansson H, Gustavsson P, Wennerberg J, Biorklund A, Rutqvist LE. Smoking tobacco, oral snuff, and alcohol in the aetiology of squamous cell carcinoma of the head and neck. Cancer 1998;82:1367-75.

6. Forastiere A, Koch W, Trotti A, Sidransky D. Head and neck cancer. N Engl J Med 2001;345:1890 -900 .

7. Johnson N. Tobacco use and oral cancer: a global perspective. J Dent Educ 2001;64:328 -39.

8. McKaig RG, Baric RS, Olshan AF. Human papillomavirus and head and neck cancer: epidemiology and molecular biology. Head Neck 1998;20:250-65.

9. Gillison ML, Wayne MK, Capone RB, Spafford M, Westra WH, Wu L, Zahurak ML, Daniel RW, Viglione $M$, Symer DE, Shah KV, Sidransky D. Evidence for a causal association between human papillomavirus and a subset of head and neck cancers. J Natl Cancer Inst 2000;92:709 -20.

10. Van Houten VMM, Snijders PJF, Van den Brekel MWM, Kummer JA, Meijer CJLM, Van Leeuwen B, Denkers F, Smeele LE, Snow GB, Brakenhoff RH. Biological evidence that human papillomaviruses are etiologically involved in a subgroup of head and neck squamous cell carcinomas. Int J Cancer 2001;93:232-5.

11. Franceschi S, Munoz N, Bosch XF, Snijders PJF, Walboomers JMM. Human papillomavirus and cancers of the upper aerodigestive tract: a review of epidemiological and experimental evidence. Cancer Epidemiol Biomarkers Prev 1996;5:567-75.

12. zur Hausen H. Papillomaviruses and cancer: from basic studies to clinical application. Nat Rev Cancer 2002;2:342-50.

13. Cullen AP, Reid R, Campion M, L örincz AT. Analysis of the physical state of different human papillomavirus DNAs in intraepithelial and invasive cervical neoplasm. J Virol 1991;65:606 -12.

14. Koopman LA, Szuhai K, Van Eendenburg JJDH, Bezrookove V, Kenter GG, Schuuring E, Tanke H, Fleuren GJ. Recurrent integration of human papillomaviruses 16, 45, and 67 near translocation breakpoints in new cervical cancer cell lines. Cancer Res 1999;59:5615-24.

15. Hopman AHN, Smedts F, Ummelen M, Dignef W, Speel EJM, Ramaekers FCS. Highly sensitive detection of human papillomavirus in cervical CIN lesions, microinvasive and invasive carcinoma. Cytometry 2002; Suppl 11:71 [abstract 44083].

16. Münger K, Scheffner M, Huibregtse JM, Howley PM. Interactions of HPV E6 and E7 oncoproteins with tumor suppressor gene products. Cancer Surv 1992;12:197-217.

17. Kubbutat MHG, Vousden $\mathrm{KH}$. Role of E6 and E7 oncoproteins in HPV-induced anogenital malignancies. Semin Virol 1996;7:295-304.

18. Snijders PJF, Steenbergen RDM, Top B, Scott SD, Meijer CJLM, Walboomers JMM. Analysis of p53 status in tonsillar carcinomas associated with human papillomavirus. J Gen Virol 1994;75:2769 -75.

19. Barten M, Ostwald C, Mildelangosch K, Müller P, Wukasch Y, Löning T. HPV DNA and p53 alterations in oropharyngeal carcinomas. Virchows Arch 1995;427:153-7.

20. Fouret P, Dabit D, Sibony M, Alili D, Commo F, Saint-Guily JL, Callard P. Expression of p53 protein related to the presence of human papillomavirus infection in precancerous lesions of the larynx. Am J Pathol 1995;146:599-604. 
39. Schwartz SM, Daling JR, Doody DR, Wipf GC, Carter JJ, Madeleine MM, Mao EJ, Fitzgibbons ED, Huang S, Beckmann AM, MCDougall JK, Galloway DA. Oral cancer risk in relation to sexual history and evidence of human papillomavirus infection. J Natl Cancer Inst 1998; 90:1626 -36.

40. Veltman JA, Hopman AHN, Bot FJ, Ramaekers FCS, Manni JJ. Detection of chromosomal aberrations in cytologic brushes from head and neck squamous cell carcinoma. Cancer Cytopathol 1997;81:30914.

41. Wilczynski SP, Lin BTY, Xie Y, Paz IB. Detection of human papillomavirus DNA and oncoprotein overexpression are associated with distinct morphological patterns of tonsillar squamous cell carcinoma. Am J Pathol 1998;152:145-56.

42. Frish M, Biggar RJ. Aetiological parallel between tonsillar and anogenital squamous-cell carcinomas. Lancet 1999;354:1442-3.

43. Francesschi S, Munoz N, Snijders PJF. How strong and how wide is the link between HPV and oropharyngeal cancer? Lancet 2000;356: 871-2.

44. Sisk EA, Soltys SG, Zhu S, Fisher SG, Carey TE, Bradford CR. Human papillomavirus and p53 mutational status as prognostic factors in head and neck carcinoma. Head Neck 2002;24:841-9.

45. Kropveld A, Rozemuller EH, Leppers FG, Scheidel KC, De Weger RA, Koole R, Hordijk GJ, Slootweg PJ, Tilanus MG. Sequencing analysis of RNA and DNA of exons 1 through 11 shows p53 gene alterations to be present in almost 100\% of head and neck squamous cell cancers. Lab Invest 1999;79:347-53.

46. Susuki H, Tomida A, Tsuruo T. Dephosphorylated hypoxia-inducible factor 1_ as a mediator of p53dependent apoptosis during hypoxia. Oncogene 2001;20:5779-88.

47. Marchetti A, Buttitta F, Pellegrini S, Merlo G, Chella A, Angeletti CA, Bevilacqua G. MDM2 gene amplification and overexpression in non-small cell lung carcinomas with accumulation of the p53 protein in the absence of p53 mutations. Diagn Mol Pathol 1995;4:93-7.

48. Lindel K, Beer K, Laissue J, Geiner RH, Aebersold DM. Human papillomavirus positive squamous cell carcinoma of the oropharynx. A radiosensitive subgroup of head and neck carcinoma. Cancer 2001; 92:805-13.

49. Sisk EA, Bradford CR, Jacob A, Yian CH, Staton KM, Tang G, Harris MO, Carey TE, Lancaster WD, Gregoire L. Human papillomavirus infection in "young" versus "old" patients with squamous cell carcinoma of the head and neck. Head Neck 2000;22:649 -57. 


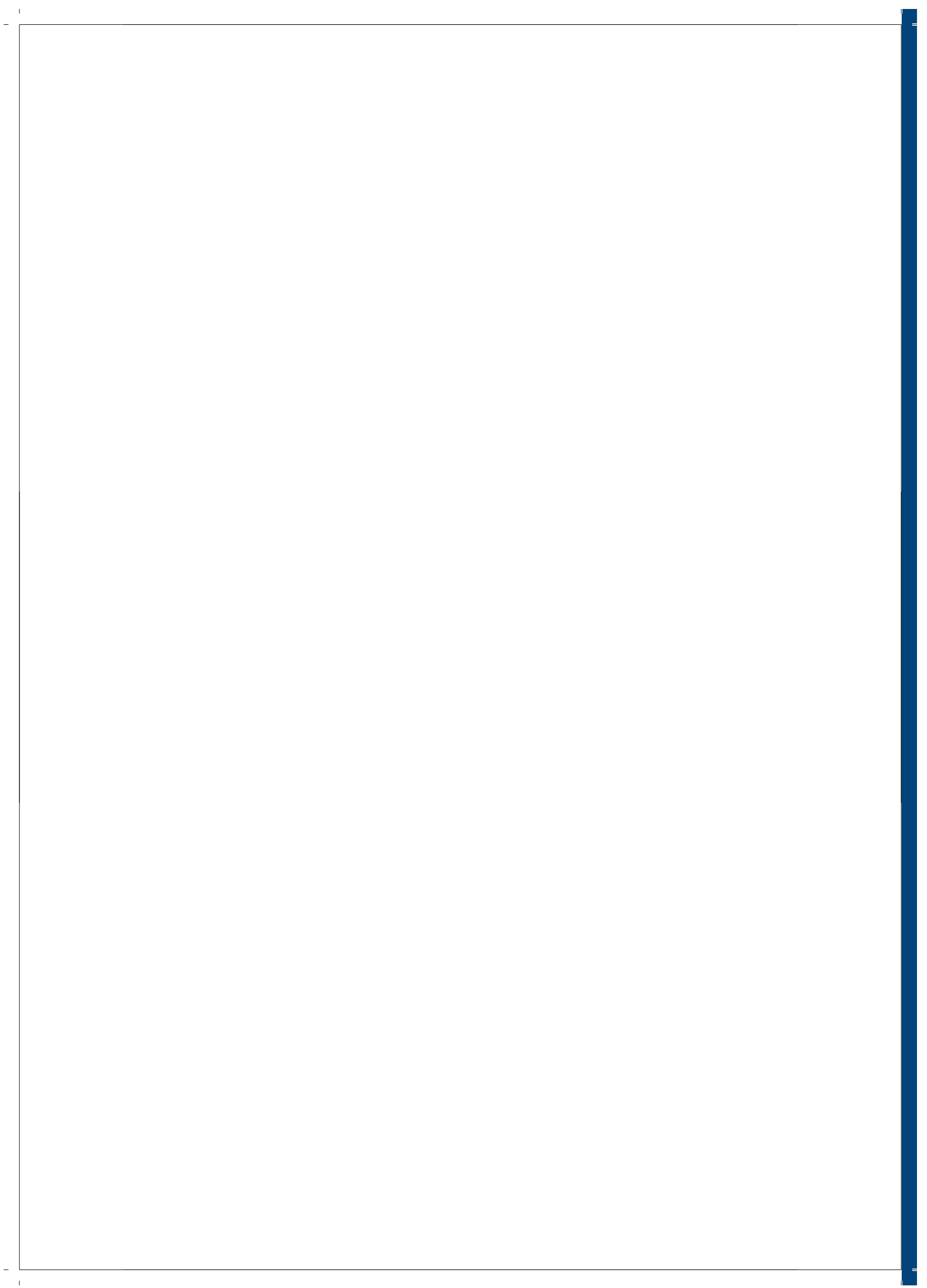




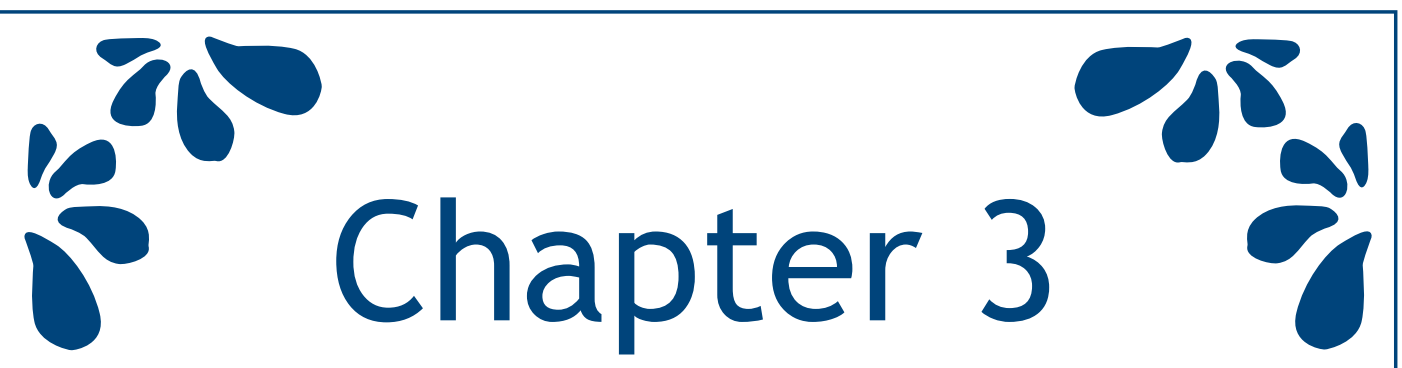

Marked differences in survival rate between

smokers and non-smokers

with HPV 16-associated

tonsillar carcinomas

Harriët C. Hafkamp, Johannes J. Manni, Annick Haesevoets, A.C. Voogd,

Adri C. Schepers, Fredrik J. Bot, Anton H.N. Hopman, Frans C.S. Ramaekers, and Ernst J.M. Speel

International Journal of Cancer 2008;122,2656-64
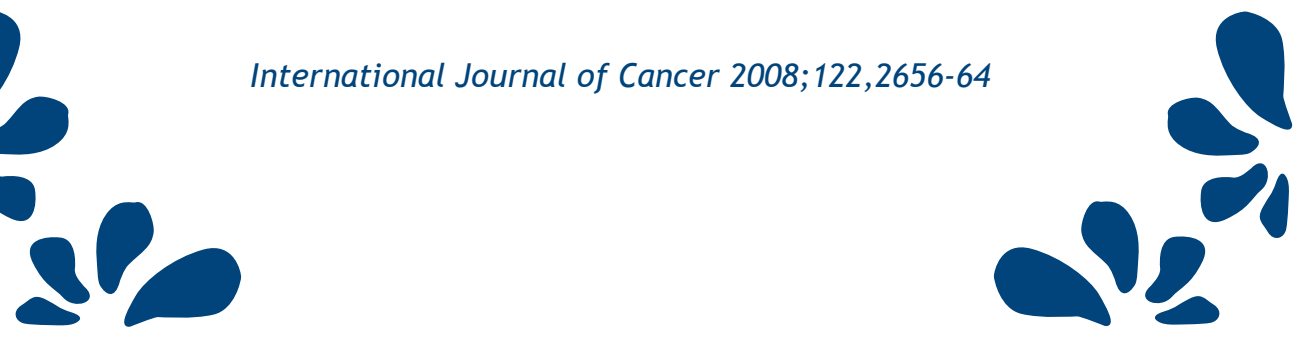


\begin{abstract}
Oncogenic human papillomavirus (HPV) is a causative agent in a subgroup of head and neck carcinomas, particularly tonsillar squamous cell carcinomas (TSCC). This study was undertaken because controversial data exist on the physical status of HPV-DNA and the use of $\mathrm{p} 16^{1 \mathrm{NK} 4 \mathrm{~A}}$ overexpression as surrogate HPV marker, and to examine the impact of HPV and tobacco consumption on the clinical course of TSCC. Tissue sections of 81 TSCC were analyzed by HPV 16-specific fluorescence in situ hybridization (FISH) and p16 ${ }^{\text {INK4A }}$-specific immunohistochemistry. Results were correlated with clinical and demographic data. HPV 16 integration was detected by FISH as punctate signals in 33 out of $81(41 \%)$ TSCC, 32 of which showed p16 $16^{\text {INK4A }}$ accumulation. Only 5 out of $48 \mathrm{HPV}$-negative tumors showed p $16^{\mathrm{INK} 4 \mathrm{~A}}$ immunostaining $(P<0.0001)$. The presence of HPV furthermore correlates significantly with low tobacco $(P=0.002)$ and alcohol intake $(P=0.011)$, poor differentiation grade $(P=$ 0.019), small tumor size $(P=0.024)$, presence of a local metastases $(P=0.001)$ and a decreased (loco)regional recurrence rate $(P=0.039)$. Statistical analysis revealed that smoking significantly increases the risk of cancer death from TSCC and that non-smoking patients with HPV-containing TSCC show a remarkably better diseasespecific survival rate. HPV 16 is integrated in $41 \%$ of TSCC and strongly correlates with $\mathrm{p} 16^{\mathrm{INK} 4 \mathrm{~A}}$ overexpression, implicating the latter to be a reliable HPV biomarker. Patients with HPV-positive tumors show a favorable prognosis as compared to those with HPV-negative tumors, but tobacco use is the strongest prognostic indicator. These findings indicate that oncogenic processes in the tonsils of non-smokers differ from those occurring in smokers, the former being related to HPV 16 infection.
\end{abstract}




\section{Introduction}

Head and neck squamous cell carcinomas (HNSCC) account for $4 \%$ of all malignancies in the Western world, for up to $50 \%$ of all malignancies in Southeast Asian countries and for $6.5 \%$ of all annual cancer cases worldwide ${ }^{1}$. HNSCC is associated with severe disease- and treatment-related morbidity and because treatment has not improved greatly in recent years, the 5 -year survival rate remains approximately $50 \%$. HNSCC develop in various anatomical defined regions, including the oral cavity, larynx and pharynx. These organ-specific tumors each show specific clinical presentations and outcome, and are treated by different strategies ${ }^{2,3}$. The median age at presentation is 60 years and approximately two third of patients are male ${ }^{1}$.

Well-known risk factors in the etiology of HNSCC are cigarette smoking combined with alcohol consumption in Western countries, or with betel quid chewing in Asia. A history of tobacco use is present in $90 \%$ of patients who develop oral cavity cancers ${ }^{2,3}$. Despite these evident associations, the exact mechanisms by which these factors cause tumor initiation and progression are not fully understood. Furthermore, the fact that most tobacco and alcohol users do not develop HNSCC and that in recent years more often individuals without a history of these traditional risk factors have been witnessed ${ }^{4}$, underlines the complexity of HNSCC pathogenesis and a role for additional factors in the disease process.

Increasing evidence suggests that human oncogenic papillomaviruses (HPVs), known to cause uterine cervical and other anogenital cancers, may also be of importance in the pathogenesis of $\mathrm{HNSCC}^{5}$. The strongest association has been found for oropharyngeal carcinomas, especially tonsillar carcinomas ${ }^{6-11}$. Sero-positive patients for HPV 16 or with a history of HPV-related anogenital cancer also show increased risk rates of developing oropharyngeal cancer ${ }^{12,13}$. The prevalence of HPVexhibiting HNSCC, however, varies broadly amongst several studies (2-76\%) due to differences in the population, combination of histological subsites, type and number of specimens analyzed, and detection methods used ${ }^{7,14}$. Thus, besides determining the presence of HPV DNA it has been suggested to better define the biological association of oncogenic HPV with these tumors, e.g. by means of assessing the viral copy number per cell, the viral oncoprotein E6/E7 expression levels, perturbation of pRb-dependent cell cycle control, or the physical status of the virus (episomal or integrated $)^{15}$. In this way, several reports have shown that HPV 16 is predominantly identified in oropharyngeal carcinomas, with a frequency of approximately 50$70 \% 9,16-18$. 
Integration of high-risk HPV DNA, such as HPV 16 DNA, into the human cellular genome is considered an important step in malignant transformation ${ }^{19}$. From studies on lesions of the uterine cervix it has become clear that viral integration marks the transition from a dysplastic lesion to (micro)invasive cancer ${ }^{20,21}$. After integration and disruption of (part of) the viral early gene E2, an upregulation of the oncoproteins E6 and E7 is detected ${ }^{7,19}$. On the one hand the E6 protein interacts specifically with the host-cell tumor suppressor protein p53 and induces its degradation. The subsequent inability to inhibit cell growth and induce apoptosis results in genetic instability. P53 mutations are therefore not a prerequisite in HPVrelated tumorigenesis, and are therefore stand seldomly identified $8,9,18$. On the other hand, the E7 protein inactivates the retinoblastoma tumor suppressor protein $\mathrm{pRb}$, resulting in release of the transcription factor E2F and upregulation of p14 ARF and $\mathrm{p} 16^{\text {INK4A } 22,23}$. In oropharynx and especially tonsillar carcinomas, however, the literature is controversial with respect to viral integration. Results range from virus being present only in an episomal form to $100 \%$ viral integration, with or without concurrent episomal HPV18,24,25. Also immunohisto-chemical detection of p16 INK4A overexpression, which has been postulated as a fast, easy and less expensive alternative for the detection of HPV infection in tonsillar cancer, may remain negative in cases where the gene is inactivated ${ }^{17,26-28}$.

With respect to the clinical course and prognosis of HPV-related tonsillar squamous cell carcinomas (TSCC), varying observations have been reported. Some authors described a survival advantage of HPV-positive TSCC patients when compared to HPV-negative cases $^{8,29-31}$, while others showed the opposite result ${ }^{32}$ or could not show a difference in survival outcome ${ }^{33,34}$. In addition, it has been suggested that the clinical course of the disease might be gender-specific, since males with a HPVpositive tumor had a better prognosis than males with a HPV-negative tumor, whereas this correlation could not be detected in women ${ }^{29}$. It has also been postulated that HPV would be more prevalent in younger patients ${ }^{33,35}$.

In the present study we have analyzed a series of 81 TSCC for HPV 16 using fluorescence in situ hybridization (FISH). This technique allows the visualization of 1 copy of HPV DNA in tumor cells, and at the same time the determination of the physical status (integrated versus episomal) of the virus on basis of the nuclear staining pattern. HPV 16 detection in the tumor was also correlated with p16 INK4A overexpression, in order to investigate whether or not this method is reliable to distinguish between HPV-positive and HPV-negative TSCC. Furthermore, clinico- 
pathological characteristics, smoking, alcohol intake and disease outcome were correlated with HPV status.

\section{Materials and methods}

\section{Tumor material and patient data}

The study population consisted of 81 patients with a TSCC diagnosed between 1992 and 2001. Formaldehyde-fixed, paraffin-embedded archival biopsy and resection materials from these patients were selected from the archives of the Department of Pathology, University Hospital Maastricht, The Netherlands. Information on patient gender, age, smoking and alcohol consumption, treatment modality, date and cause of death, as well as tumor site, differentiation grade and TNM classification were collected from review of clinical, pathological, radiological and surgical reports. Patients were classified as daily tobacco smokers ( $\geq 1$ cigarette, pipe, and/or cigar per day) or non-smokers (never smoker $(n=10)$ or former smoker $(n=2)$, which are those who had stopped smoking more than 10 years before the diagnosis of TSCC). Patients were also classified as drinkers (consumption of $>2$ whiskey equivalents per day ( 1 whiskey equivalent $\sim 10 \mathrm{~g}$ alcohol)) or non-drinkers (0-2 whiskey equivalents per day). All patients were treated by surgery, radiotherapy, chemotherapy or a combination irrespective of their HPV status. The study protocol was approved by the institutional ethical committee, and all of the patients gave informed consent.

When available the tissue sections were taken from the resection specimen. Otherwise biopsy material was used for examination. A series of $4 \mu \mathrm{m}$-thick sections was cut from the specimens for detailed histopathological reclassification on basis of hematoxylin-eosin staining (F.J.B.), including the scoring of tumor grade (i.e., well, moderately, or poorly differentiated) according to the criteria of the World Health Organization $^{36}$. Furthermore, we applied FISH to identify HPV 16 infestation and immunohistochemistry to visualize $\mathrm{p} 16^{\mathrm{INK} 4 \mathrm{~A}}$ expression.

\section{Detection of HPV 16 DNA by FISH}

FISH for the detection of HPV 16 was performed on 4- $\mu$ m thick tissue sections as described previously ${ }^{18,21}$. Formaldehyde-fixed, paraffin-embedded sections were deparaffinized, pre-treated with $85 \%$ formic acid/0.3\% $\mathrm{H}_{2} \mathrm{O}_{2}$ for 20 minutes at room temperature, and subsequently dehydrated in an ethanol series starting with $70 \%$ 
ethanol containing $0.01 \mathrm{M} \mathrm{HCl}$ (acidic dehydration). After air drying, the preparations were treated with $1 \mathrm{M} \mathrm{NaSCN}$ for 10 minutes at $80^{\circ} \mathrm{C}$, followed by acidic dehydration and digestion with $4 \mathrm{mg} / \mathrm{ml}$ pepsin (800-1,200 U/mg protein from porcine stomach mucosa; Sigma Chemical Co., St. Louis, MO, USA) in $0.02 \mathrm{M} \mathrm{HCl}$. The slides were rinsed three times in $0.01 \mathrm{M} \mathrm{HCl}$, acidically dehydrated, air dried, post-fixed in $1 \%$ formaldehyde in PBS for 15 minutes at room temperature and dehydrated in an ethanol series starting with $70 \%$ ethanol in distilled water. The digoxigenin-labeled HPV 16 probe (Panpath, Amsterdam, The Netherlands) was applied under a coverslip at a concentration of $1 \mathrm{ng} / \mu \mathrm{l}$ in $60 \%$ formamide, $2 \times$ SSC, $10 \%$ dextran sulphate, and a 50x excess of carrier DNA (salmon sperm DNA). Probe and target DNA were denatured simultaneously for 5 minutes at $80^{\circ} \mathrm{C}$ prior to hybridization overnight at $37^{\circ} \mathrm{C}$ in a humid chamber. After hybridization the preparations were washed stringently in $50 \%$ formamide, $2 \times \mathrm{SSC}, \mathrm{pH} 7.0$ at $42^{\circ} \mathrm{C}$ ( 2 times $5 \mathrm{~min}$ ). The digoxigenin-labeled probe was detected with peroxidase-conjugated sheep anti-digoxigenin Fab fragments (Roche, Basel, Switzerland; 1:100 diluted in 4xSSC containing 5\% non-fat dry milk), followed by a tyramide signal amplification (TSA) reaction using rhodamine-labeled tyramide ${ }^{18,21,37} .50 \mu$ rhodamine-labeled tyramide (1:500 diluted from a $1 \mathrm{mg} / \mathrm{ml}$ stock solution in ethanol) in PBS containing $0.1 \mathrm{M}$ imidazole, $\mathrm{pH} 7.6$, and $0.001 \%$ $\mathrm{H}_{2} \mathrm{O}_{2}$ was applied under a coverslip for 10 minutes at $37^{\circ} \mathrm{C}$. Finally, the slides were washed in PBS containing 0.05\% Tween-20 (Janssen Chimica, Beerse, Belgium) and PBS, dehydrated in an ascending ethanol series and mounted in Vectashield (Vector Laboratories, Burlingame, USA) containing $0.2 \mu \mathrm{g} / \mathrm{ml}$ 4',6-diamidino-2-phenyl indole (DAPI; Sigma). Slides were evaluated under the microscope and images were recorded with the Metasystems Image Pro System (black and white CCD camera; Sandhausen, Germany) mounted on top of a Leica DM-RE fluorescence microscope equipped with DAPI and rhodamine filters.

\section{Controls and evaluation of FISH results}

Controls included hybridizations on 1) $70 \%$ ethanol-fixed cell suspensions and formaldehyde-fixed sections of paraffin-embedded cell pellets of human uterine cervical carcinoma cell lines with known HPV 16 copy number, i.e. CaSki (ATCC; CRL1550; 500 integrated HPV 16 copies), SiHa (ATCC; HTB35; 1-2 integrated HPV 16 copies) and HeLa (ATCC; CCL2; 20-50 integrated HPV 18 and no HPV 16 copies); and 2) formaldehyde-fixed, paraffin-embedded tissue sections of human uterine cervical lesions with proven integration or episomal presence (replication) of HPV 16 genomic 
DNA to guarantee probe specificity, sensitivity and interpretation accuracy ${ }^{18,21}$. Negative controls consisted of HPV PCR- and FISH-negative cell lines (the bladder transitional cell carcinoma line T24 and the endocrine pancreatic tumor line BON-1) and tissue sections.

Evaluation of FISH signals was performed by three investigators (H.C.H, A.H., E.J.M.S.) according to the criteria first described by Cooper et al. ${ }^{38}$, i.e. punctate and/or diffuse nuclear signals indicate the presence of integrated and/or episomal HPV DNA, respectively ${ }^{18,21}$. These criteria are based on the correlation of these FISH signal patterns with restriction digestion and Southern blot hybridization results to detect integrated or replicative (episomal) $\mathrm{HPV}^{38}$. In a recent preliminary study HPV integration as detected by punctate FISH signals also strongly correlated with the presence of fusion transcripts as detected by the amplification of papilloma virus oncogene transcripts (APOT) assay ${ }^{20}$ in 10 TSCC and 10 uterine cervical SCC (unpublished observations).

\section{Immunohistochemical staining of p16 INK4A}

Immunohistochemical staining of $\mathrm{p} 16^{\text {INK4A }}$ on $4 \mu \mathrm{m}$-thick formaldehyde-fixed, paraffin-embedded tissue sections was performed as described earlier ${ }^{18}$. Sections were deparaffinized and subsequently pretreated with $2 \% \mathrm{H}_{2} \mathrm{O}_{2}$ in methanol for 30 minutes to quench endogenous peroxidase activity. Antigen retrieval was performed by microwave heating in $0.01 \mathrm{M}$ citrate buffer $(\mathrm{pH} 6.0)$. The monoclonal antibody E6H4 (Dako, Glostrup, Denmark) was used to detect the p16 INK4A $^{\text {protein. After }}$ incubation with biotinylated horse anti-mouse antibody, immunohistochemical detection was performed by the avidin-biotinylated peroxidase complex ( $A B C)$ procedure (both Vectastain-Elite-ABC kit; Vector). Peroxidase activity was detected using diaminobenzidine $/ \mathrm{H}_{2} \mathrm{O}_{2}$. Sections were counterstained with hematoxylin and mounted in Entellan (Merck, Darmstadt, Germany). In each analysis, negative and positive controls were included. Analysis was performed by three independent observers (H.C.H., M.S. and E.J.M.S.) and consensus was acquired. Levels of p16 $16^{\text {INK4A }}$ expression in normal squamous epithelium are under the detection limit of immunohistochemistry. Strong nuclear and cytoplasmic p1 $16^{\mathrm{INK} 4 \mathrm{~A}}$ staining in $\geq 25 \%$ of

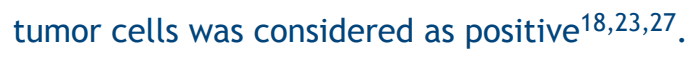




\section{Detection of high risk HPV DNA by PCR}

Genomic DNA was extracted from 5-10 $10 \mu \mathrm{m}$-thick tissue sections of a subset of 25 TSCC according to the tissue protocol of the QIAamp DNA mini kit using proteinase $K$ (Qiagen, Westburg, Leusden, The Netherlands) ${ }^{18}$. B-Globin gene PCR was performed with all DNA samples to demonstrate that they contained sufficient DNA of adequate quality and were free of substances inhibitory to PCR (268 bp PCO4/GH20 PCR product) ${ }^{17}$. HPV 16 -specific PCR was performed according to Baay et al. ${ }^{39}$. In 5 tumors that were negative for HPV 16 but positive for p16 $16^{\text {NK } 4 \mathrm{~A}}$, both a general primer GP5+/6+ PCR (150 bp product) and a nested PCR with degenerate primers A5/A10 (527 bp product) and A6/A8 (268 bp product) for HPV were performed ${ }^{40}$. PCR products $(5 \mu \mathrm{l})$ were separated on $2 \%$ agarose gels and visualized by ethidium bromide staining. For HPV typing biotinylated A6/A8-PCR products were hybridized with 37 type-specific digoxigenin-labeled oligonucleotide probes in an enzyme-immunoassay (EIA) as previously described ${ }^{41}$.

\section{Statistical analysis}

Factors associated with HPV status, including presence of p16 $16^{\text {NK } 4 \mathrm{~A}}$ overexpression, gender, age at time of diagnosis, smoking and alcohol use, TNM status and grade of the tumors, were analyzed by cross-tabulations using the 2-tailed Fisher exact test. A significance level of $P \leq 0.05$ was chosen for all analyses.

Disease-specific and overall survival curves were calculated using the KaplanMeier method ${ }^{42}$. Survival was calculated from the date of diagnosis until death or until the last date the patient was known to be alive. Patients that died of other causes than tonsillar carcinoma were considered censored observations in the disease-specific survival analyses. Disease-free survival was calculated from the date of diagnosis until the date of recurrence (local, regional or distant, whichever occurred first). Patients without recurrence were censored at the date of the last follow-up or the date of death. The statistical significance of differences between survival times was determined by the log rank test in univariate analyses ${ }^{43}$ using a significance level of $p \leq 0.05$.

Multivariate analyses were performed using the Cox proportional hazards model. Variables included were HPV, smoking, alcohol consumption, and T-classification. Variables remained in the model if their $P$ values were below 0.10 . All calculations were performed by use of the SPSS Base System version 11.5. 


\section{Results}

\section{Clinico-pathologic characteristics of the study population}

Table 1 provides demographic and clinical features of the 81 patients included in this study. Seventy-three percent of the patients were male. Patient ages ranged from 39-87 years with a mean of 58.9 years.

Data concerning smoking and alcohol intake could be obtained from 80 patients. Sixty-eight of $80(84 \%)$ patients were smokers and 49 of $80(61 \%)$ consumed more than 2 units of alcohol per day. Twenty-three (28\%) of the 80 patients consumed only tobacco, $4(5 \%)$ only alcohol and $45(56 \%)$ used both tobacco and alcohol, while there were only $8(10 \%)$ patients without intoxication of alcohol or tobacco.

At time of diagnosis 40 of the 81 (49\%) patients presented with a tumor $<4$

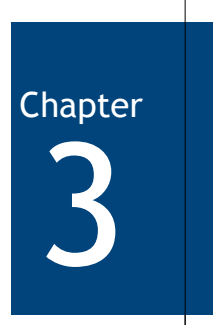
$\mathrm{cm}$ in diameter. Fifty-nine $(73 \%)$ patients had lymph node metastasis at time of diagnosis, and in $22(27 \%)$ ultrasonography and MRI could not detect a lymph node metastasis. The grade of the squamous cell carcinomas was poor or moderate in 29 (36\%) patients, while the tumors were well differentiated in $49(60 \%)$ patients.

Treatment modalities consisted of surgery, radiotherapy, chemotherapy or combinations of these (Table 1). Thirty patients were never disease free, $17(21 \%)$ patients developed a recurrent disease (12 at the primary site (local) and 5 in the neck (regional)) and 34 (42\%) patients remained disease free after primary treatment. In addition, 6 patients developed a second primary tumor.

\section{HPV 16-containing tonsillar carcinomas and correlation with p16 INK4A overexpression}

Thirty-three (41\%) out of the 81 TSCC contained punctate, nuclear HPV 16 FISH signals in $>25 \%$ of tumor cells, indicating viral integration into the cellular genome (Figure 1A). In the other tumors no specific HPV 16 FISH signals were detected. Twenty-six of the HPV-positive tumors showed 1 integration site per nucleus, while the remaining tumors harbored either 2 integration sites per nucleus $(n=1)$, or two tumor areas with, respectively, 1 and 2 integration sites per nucleus $(n=1)$, or tumor areas with, respectively, 1 integration site per nucleus and $>1$ nuclear signals varying significantly in size and intensity (termed granular FISH pattern; $n=5$ ). In addition, 11 of the $33 \mathrm{HPV}$ 16-positive tumors showed evidence for a concomitant replication of the virus in specific areas of the tumor as visualized by diffusely stained nuclei (Figure 1B). Interestingly, 32 out of the 33 (97\%) HPV-positive TSCC also exhibited 
TABLE 1. P16 INK4A AND CLINICOPATHOLOGICAL DATA OF THE STUDY POPULATION GROUPED BY HPV 16 INTEGRATION STATUS.

\begin{tabular}{|c|c|c|c|c|}
\hline Characteristic & $\begin{array}{l}\text { Total TSCC } \\
\mathrm{n}=\mathbf{8 1}(\%)\end{array}$ & $\begin{array}{c}\text { HPV-positive } \\
n=33(\%)\end{array}$ & $\begin{array}{c}\text { HPV-negative } \\
n=48(\%)\end{array}$ & $\begin{array}{c}\text { Fisher exact } \\
\text { P }\end{array}$ \\
\hline \multicolumn{5}{|l|}{ P16 ${ }^{\text {INK4A }}$ overexpression ${ }^{1}$} \\
\hline Yes & $37(46)$ & $32(97)$ & $5(10)$ & \multirow[t]{2}{*}{$<0.0001$} \\
\hline No & $44(54)$ & $1(3)$ & $43(90)$ & \\
\hline \multicolumn{5}{|l|}{ Gender } \\
\hline Male & $59(73)$ & $24(73)$ & $35(73)$ & \multirow[t]{2}{*}{ NS } \\
\hline Female & $22(27)$ & $9(27)$ & $13(27)$ & \\
\hline Mean age at diagnosis (y) & 58.9 & 59.8 & 58.2 & NS \\
\hline \multicolumn{5}{|l|}{ Intoxication } \\
\hline Smoking & $23(28)$ & $11(33)$ & $12(25)$ & \\
\hline Alcohol & $4(5)$ & $3(9)$ & $1(2)$ & \\
\hline Smoking + alcohol & $45(56)$ & $11(33)$ & $34(71)$ & \\
\hline None & $8(10)$ & $7(21)$ & $1(2)$ & \\
\hline Unknown & $1(1)$ & $1(3)$ & 0 & \\
\hline \multicolumn{5}{|l|}{ Smoking ${ }^{2}$} \\
\hline Yes & $68(84)$ & $22(70)$ & $46(96)$ & \multirow[t]{3}{*}{0.002} \\
\hline No & $12(15)$ & $10(30)$ & $2(4)$ & \\
\hline Unknown & $1(1)$ & 1 & 0 & \\
\hline \multicolumn{5}{|l|}{ Alcohol intake ${ }^{3}$} \\
\hline Yes & $49(61)$ & $14(42)$ & $35(73)$ & \multirow{3}{*}{0.011} \\
\hline No & $31(38)$ & $18(58)$ & $13(27)$ & \\
\hline Unknown & $1(1)$ & 1 & 0 & \\
\hline \multicolumn{5}{|l|}{ Complaints at diagnosis } \\
\hline Local & $56(69)$ & $15(46)$ & $41(85)$ & \multirow[t]{3}{*}{0.001} \\
\hline Metastasis & $20(25)$ & $14(42)$ & $6(13)$ & \\
\hline Unknown & $5(6)$ & $4(12)$ & $1(2)$ & \\
\hline \multicolumn{5}{|l|}{ Lymph node metastasis ${ }^{4}$} \\
\hline Positive & $59(73)$ & $26(79)$ & $33(69)$ & \multirow[t]{2}{*}{ NS } \\
\hline Negative & $22(27)$ & $7(21)$ & $15(31)$ & \\
\hline \multicolumn{5}{|l|}{ T-classification } \\
\hline$\geq 4 \mathrm{~cm}(\mathrm{~T} 3-4)$ & $40(49)$ & $11(33)$ & $29(60)$ & \multirow[t]{2}{*}{0.024} \\
\hline$<4 \mathrm{~cm}(\mathrm{~T} 1-2)$ & $41(51)$ & $22(67)$ & $19(40)$ & \\
\hline \multicolumn{5}{|l|}{ Tumor grade ${ }^{5}$} \\
\hline Poor/moderate & $29(36)$ & $17(52)$ & $12(25)$ & \multirow[t]{3}{*}{0.019} \\
\hline Well & $49(60)$ & $15(45)$ & $34(71)$ & \\
\hline Unknown & $3(4)$ & $1(3)$ & $2(4)$ & \\
\hline \multicolumn{5}{|l|}{ Primary therapy } \\
\hline Surgery & $8(10)$ & $5(15)$ & $3(6)$ & \\
\hline Surgery + RT & $36(44)$ & $17(52)$ & $19(40)$ & \\
\hline RT & $23(28)$ & $8(24)$ & $15(32)$ & \\
\hline $\mathrm{CT}+\mathrm{RT}$ & $4(5)$ & 0 & $4(8)$ & \\
\hline $\mathrm{CT}$ & $3(4)$ & $2(6)$ & $1(2)$ & \\
\hline Surgery+CT+RT & $5(6)$ & $1(3)$ & $4(8)$ & \\
\hline None & $2(3)$ & 0 & $2(4)$ & \\
\hline \multicolumn{5}{|l|}{ Recurrent disease } \\
\hline Yes & $17(21)$ & $4(12)$ & $13(27)$ & \multirow[t]{3}{*}{0.039} \\
\hline No & 34 (42) & $19(58)$ & $15(31)$ & \\
\hline Never disease free & $30(37)$ & $10(30)$ & $20(42)$ & \\
\hline \multicolumn{5}{|l|}{ Second primary tumor } \\
\hline Yes & $6(7)$ & 0 & $6(13)$ & NS \\
\hline No & $75(93)$ & $33(100)$ & $42(87)$ & \\
\hline
\end{tabular}

$H P V=$ human papillomavirus; $N S=$ not significant; $R T=$ radiation therapy; $C T=$ chemotherapy. ${ }^{1}$ Strong nuclear and cytoplasmic p $16^{\text {INK4A }}$ staining in $\geq 25 \%$ of tumor cells was considered positive and in $<25 \%$ of cells negative. ${ }^{2}$ Patients were classified as daily tobacco smokers ( $\geq 1$ cigarette, pipe, and/or cigar per day) or non-smokers (never smoker $(n=10)$ or former smoker $(n=2)$, which are those who had stopped smoking more than 10 years before the diagnosis of TSCC). ${ }^{3}$ Patients were classified as drinkers (consumption of $>2$ whiskey equivalents per day (1 whiskey equivalent $\sim 10 \mathrm{~g}$ alcohol)) or non-drinkers (0-2 whiskey equivalents per day). ${ }^{4}$ As determined by ultrasonography and MRI scanning. ${ }^{5}$ Tumor grade was scored as well-, moderately-, or poorly differentiated according to the criteria of the World Health Organization. ${ }^{36}$ 
strong nuclear and cytoplasmic staining for p16 $16^{\mathrm{INK} 4 \mathrm{~A}}$ in the tumor areas harboring cells with nuclear HPV signals (Figure 1C-D). Forty-three out of the 48 (90\%) HPVnegative TSCC did not show any expression of $\mathrm{p} 16^{\text {INK4A }}$. Thus, a highly significant correlation was found between accumulation of p16 INK4A and the presence of HPV $16(\mathrm{p}<0.0001 ;$ Table 1).
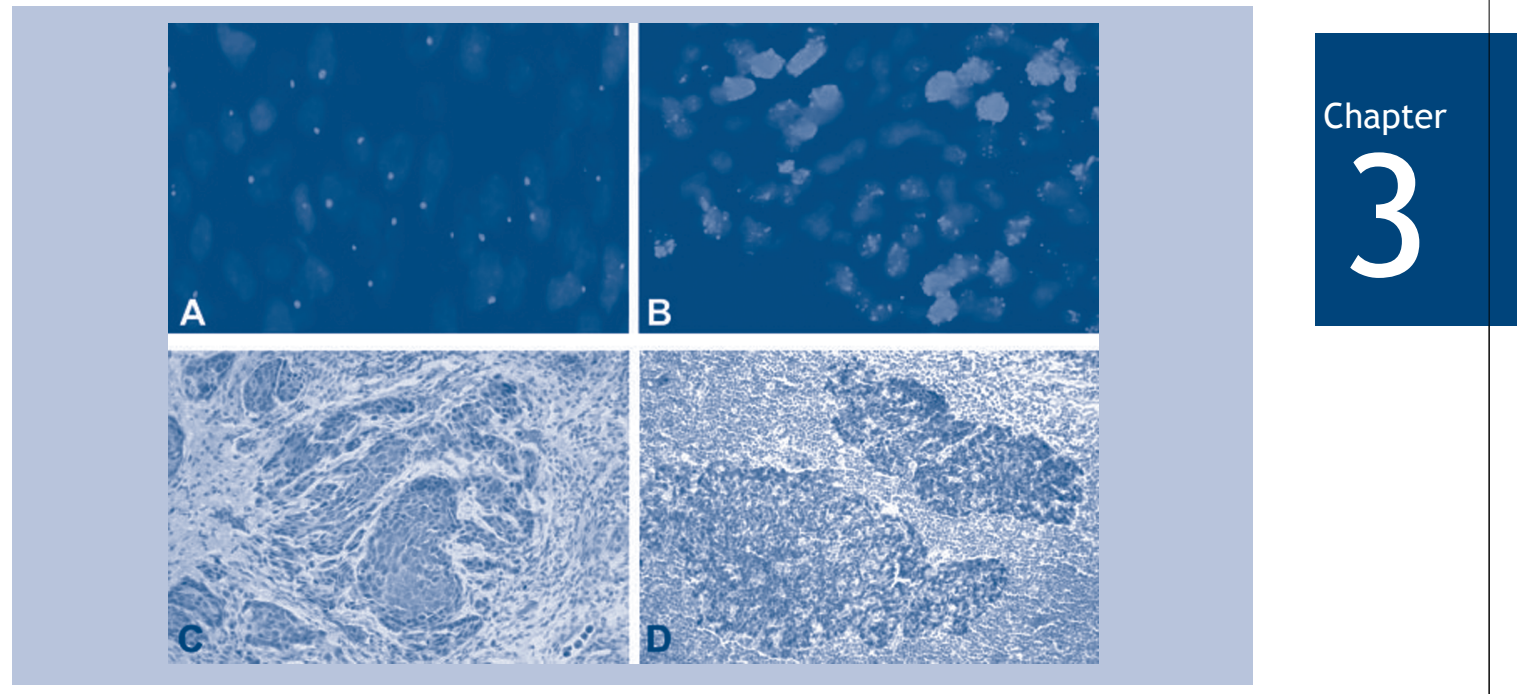

FIGURE 1. REPRESENTATIVE EXAMPLES OF HPV 16 FISHANALYSIS (A, B)AND P16 INK4A IMMUNOSTAINING (C, D) ON PARAFFIN-EMBEDDED TISSUE SECTIONS OF TSCC. (A) Example of one HPV 16-specific punctate signal per nucleus (light) indicating viral integration. Tumor cell nuclei are dark due to DAPI staining (B) Example of a tumor area showing diffuse nuclear staining (light) indicating viral replication (episomal virus copies), nuclei are DAPI counterstained. (C-D) Overexpression of $16^{\text {INK4A }}$ (dark peroxidase-diamino benzidine staining) in two HPV 16-positive TSCC, nuclei counterstained by hematoxylin (light). (see page 156 for color figure)

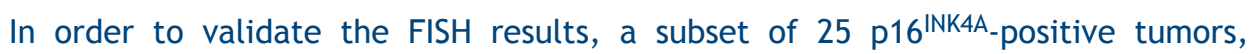
including $20 \mathrm{FISH}$-positive cases, was subjected to HPV 16-specific PCR analysis. PCR confirmed the presence of HPV 16 DNA in the $20 \mathrm{FISH}$ positive cases. The 5 remaining TSCC, however, also proved to be negative for 36 other genital/mucosal HPV types (data not shown).

\section{Clinico-pathological features related to the presence of HPV 16}

The male/female ratio and the age distribution in the study population were identical in the HPV-positive and HPV-negative subgroup (Table 1). In contrast, statistical 
analysis showed a significantly lower prevalence of smoking and drinking habits in patients with HPV-positive carcinomas than in patients with HPV-negative carcinomas ( $P=0.002$ and 0.011 , respectively). In the patients with HPV-positive carcinomas the age distribution was not different between smokers and non-smokers.

The patients with HPV-positive carcinomas presented significantly more often $(P=0.001)$ with complaints of a swelling in the neck caused by a lymph node metastasis as compared to the patients with HPV-negative carcinomas. However, there was no difference in the number of patients with tumor spread to the regional lymph nodes between the two subgroups. The primary tumor size at time of presentation was found to be significantly smaller in the HPV-positive group than in the HPV-negative group ( $P=0.024$ ), suggesting that HPV-positive tumors metastasize at a smaller size than HPV-negative tumors. The HPV-positive tumors, moreover, showed significantly more often a poor or moderate histological degree of differentiation $(P=0.019)$.

All patients were treated according to the same protocol and therapies did not differ significantly between the HPV-positive and HPV-negative subgroups. Patients with a HPV-negative tumor had a significantly higher chance $(P=0.039)$ of developing recurrent disease (27\%; 9 local and 4 regional recurrences) compared to patients with a HPV-positive tumor (12\%; 3 local and 1 regional recurrences). Recurrent disease was seen in 17 patients, and the time of occurrence ranged from 3 to 43 months after the initial diagnosis with a mean time period of 18 months. The mean recurrencefree interval was longer in the patients with HPV-positive carcinomas than in the patients with HPV-negative carcinomas, i.e. 27 vs. 16 months, respectively. Only in the HPV-negative patient group second primary tumors developed in 6 out of 48 cases $(13 \%)$.

\section{Parameters influencing patient survival}

To determine the prognostic value of the presence of HPV in tonsillar carcinomas, we analyzed both overall and disease-specific survival. Two patients died postoperatively, due to bleeding and aspiration, and were excluded from the analysis. Follow-up time ranged from 0 to 141 months, with a mean of 30 months. Fifty-three of $79(67 \%)$ patients died due to their TSCC and $8(10 \%)$ from unrelated causes. Using the Kaplan-Meier algorithm the 5-year overall and disease-specific survival was $34 \%$ and $38 \%$, respectively.

Stratification according to HPV status revealed a significantly improved 5-year overall as well as disease-specific survival for the patients with HPV-positive tumors 
compared to patients with HPV-negative tumors (log rank test: $p=0.026$ and $p$ $=0.023$, respectively; see Figure 2A). The disease-specific survival after 5 years for patients with HPV-positive carcinomas was $55 \%$, and $29 \%$ for patients with HPV-negative carcinomas (Hazard Ratio $(H R)=2.3$; Confidence Interval $(\mathrm{Cl})=1.1$ 4.5; Table 2). In the 51 patients reaching a disease-free state after therapy, the 5-year disease-free survival for patients with HPV-positive and HPV-negative tumors was $73 \%$ and $48 \%$, respectively (log rank test: $p=0.038$ ). Because of the strong correlation between HPV 16 FISH status and p16 INK4A overexpression, the diseasespecific survival curve stratified according to $\mathrm{p} 16^{\mathrm{INK} 4 \mathrm{~A}}$ status is comparable with the stratification according to HPV 16 status (log rank test: $p=0.010$ and $p=0.023$, respectively; compare Figures $2 \mathrm{~A}$ and $2 \mathrm{~B}$ ).

Apart from absence of HPV 16, other factors were found to be significantly associated with a shorter disease-specific survival in patients with TSCC in a univariate analysis. These include lack of $16^{\mathrm{INK} 4 \mathrm{~A}}$ overexpression (HR $=2.3 ; 95 \%$ $\mathrm{Cl}=1.2-4.3)$, smoking $(\mathrm{HR}=6.0 ; 95 \% \mathrm{Cl}=1.5-25$; see Figure $2 \mathrm{C})$, a combination of smoking and alcohol abuse $(\mathrm{HR}=2.8 ; 95 \% \mathrm{Cl}=1-7.7)$, a tumor diameter of $\geq 4 \mathrm{~cm}$ $(\mathrm{HR}=2.8 ; 95 \% \mathrm{Cl}=1.5-5.3)$, and development of recurrent disease $(\mathrm{HR}=15.2 ; 95 \%$ $\mathrm{Cl}=4.2-54.6$ ) (Table2). Gender, age, complaints at time of diagnosis, alcohol intake, lymph node status and tumor grade were not significantly related to disease-specific survival. Because tobacco use turned out to be the strongest individual predictor for an unfavorable prognosis, we also analyzed the predictive value of the HPV 16 status for survival in smokers, and of tobacco use in the patients with HPV 16-positive TSCC. Interestingly, HPV 16 status had no significant effect on outcome in smokers (Figure 2D). However, 10 of the 12 non-smokers also harbored HPV 16, and these patients had a significantly more favorable disease-specific survival than smokers with HPV-positive TSCC (Figure 2E). In addition, HPV-positive tumors of non-smokers were significantly smaller and less well differentiated than those of smokers $(p=$ 0.026 and 0.013 , respectively; data not shown).

Using multivariate analysis (Table 3), patients with HPV-negative TSCCs were found to exhibit a 2 times higher chance of cancer death $(95 \% \mathrm{Cl}=0.9-4.2)$ compared to patients with HPV-positive tumors. Smokers had an even higher risk (5.5 fold) $(95 \% \mathrm{Cl}=1.3-23.6)$ of dying from cancer compared to non-smokers. Patients with a tumor $\geq 4 \mathrm{~cm}$ in diameter had a 2.6 times increased risk of cancer death $(95 \% \mathrm{Cl}$ = 1.4-4.9). Other factors including gender, age, lymph node metastasis and tumor grade did not significantly influence survival in multivariate analysis. 


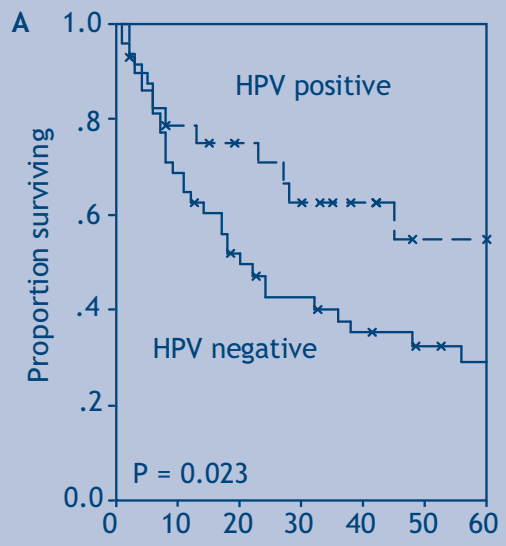

Survival time in months
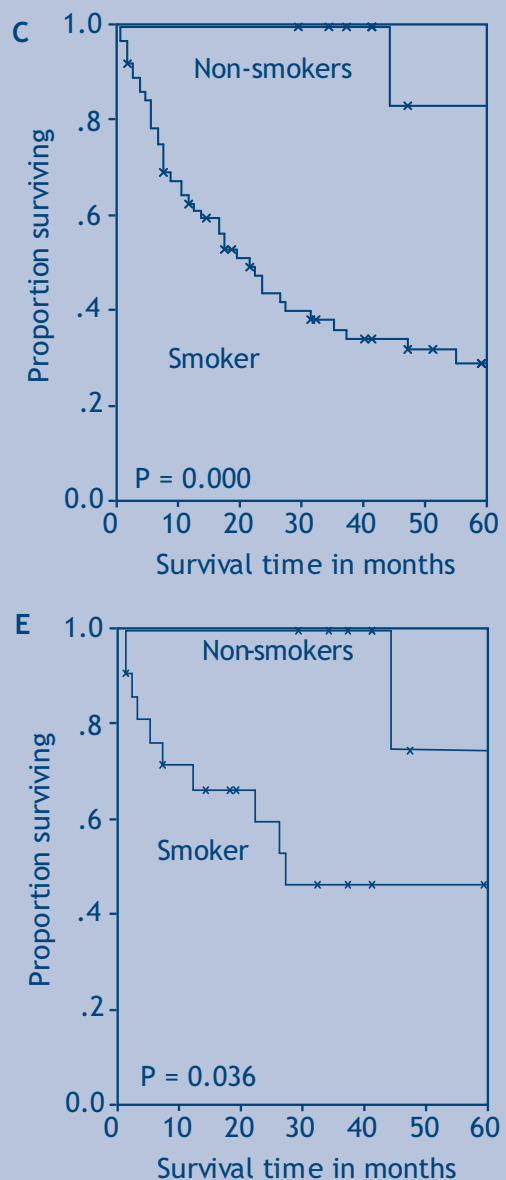

B
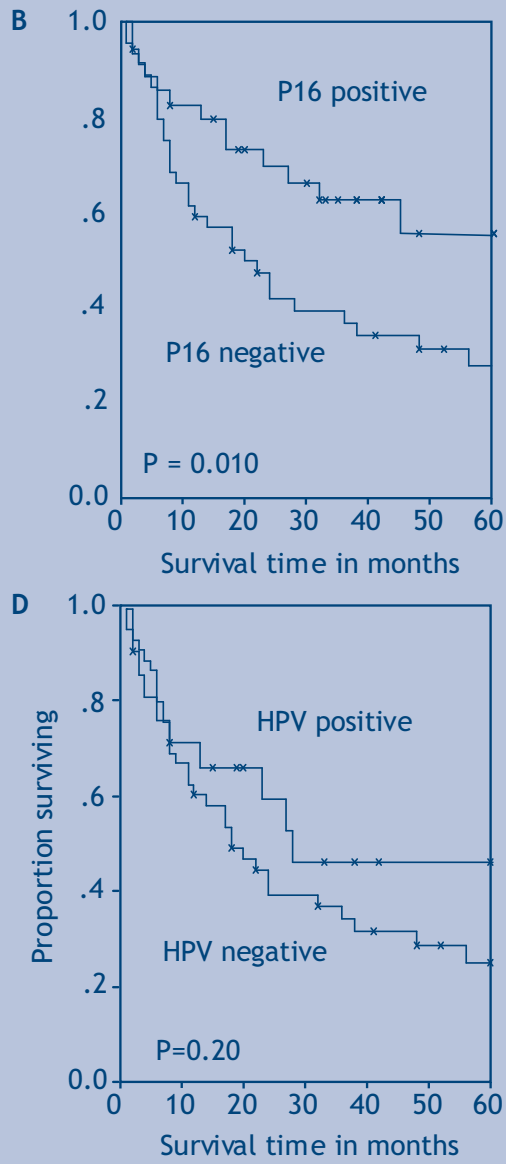

FIGURE 2. KAPLAN-MEIER PLOTS OF DISEASESPECIFIC SURVIVAL (IN MONTHS AFTER FIRST DIAGNOSIS) OF PATIENTS WITH TSCC. Stratification for A) presence of integrated HPV $16(n=$ 79); B) p16 11NK4A accumulation ( $n=79)$; $)$ tobacco use $(n=79)$; D) HPV status in smokers ( $n=$ 67); and $\mathrm{E}$ ) tobacco use in HPV-positive patients $(n=33)$. Censored values are noted with $\times$. 
TABLE 2. INFLUENCE OF HPV-RELATED AND CLINICOPATHOLOGIC PARAMETERS ON DISEASE-SPECIFIC SURVIVAL IN 79 PATIENTS WITH TSCC, AS DETERMINED BY UNIVARIATE COX PROPORTIONAL HAZARD REGRESSION ANALYSIS

\begin{tabular}{|c|c|c|c|c|}
\hline Characteristic & Total & Death (\%) & P value 1 & Unadjusted HR $(95 \% \mathrm{Cl})$ \\
\hline \multicolumn{5}{|l|}{ Integrated HPV 16} \\
\hline Positive $^{2}$ & 31 & $11(35)$ & 0.015 & 1 (referent) \\
\hline Negative & 48 & $34(71)$ & & $2.3(1.1-4.5)$ \\
\hline \multicolumn{5}{|l|}{ P16 ${ }^{\text {INK4A }}$ overexpression } \\
\hline Positive $^{2}$ & 35 & $13(37)$ & 0.010 & 1 (referent) \\
\hline Negative & 44 & $32(73)$ & & $2.3(1.2-4.3)$ \\
\hline \multicolumn{5}{|l|}{ Gender } \\
\hline Male $^{2}$ & 58 & $35(60)$ & 0.095 & 1 (referent) \\
\hline Female & 21 & $10(48)$ & & $0.6(0.3-1.1)$ \\
\hline \multicolumn{5}{|l|}{ Age } \\
\hline$<60$ years $^{2}$ & 43 & $26(60)$ & NS & 1 (referent) \\
\hline$>60$ years & 36 & $19(53)$ & & $0.8(0.4-1.4)$ \\
\hline \multicolumn{5}{|l|}{ Intoxication } \\
\hline None $^{2}$ & 8 & $1(13)$ & 0.019 & 1 (referent) \\
\hline Smoking & 23 & $17(74)$ & & $11.2(1.5-85)$ \\
\hline Alcohol & 45 & $26(58)$ & & $1.3(0.5-3.4)$ \\
\hline Smoking \& alcohol & 3 & $1(33)$ & & $2.8(1.0-7.7)$ \\
\hline \multicolumn{5}{|l|}{ Smoking } \\
\hline $\mathrm{No}^{2}$ & 11 & $2(18)$ & 0.005 & 1 (referent) \\
\hline Yes & 68 & $43(63)$ & & $6.0(1.5-25.0)$ \\
\hline \multicolumn{5}{|l|}{ Alcohol intake } \\
\hline $\mathrm{No}^{2}$ & 31 & $18(58)$ & NS & 1 (referent) \\
\hline Yes & 48 & $27(56)$ & & $1.0(0.6-1.8)$ \\
\hline \multicolumn{5}{|c|}{ Complaints at diagnosis } \\
\hline Local $^{2}$ & 55 & $36(65)$ & NS & 1 (referent) \\
\hline Metastasis & 20 & $7(35)$ & & $0.5(0.2-1.2)$ \\
\hline Unknown & 4 & & & \\
\hline \multicolumn{5}{|l|}{ Lymph node metastasis } \\
\hline Negative $^{2}$ & 21 & $13(62)$ & NS & 1 (referent) \\
\hline Positive & 58 & $32(55)$ & & $1.0(0.5-1.9)$ \\
\hline \multicolumn{5}{|l|}{ T-classification } \\
\hline$<4 \mathrm{~cm}^{2}$ & 39 & $17(44)$ & 0.001 & 1 (referent) \\
\hline$>4 \mathrm{~cm}$ & 40 & $28(70)$ & & $2.8(1.5-5.3)$ \\
\hline \multicolumn{5}{|l|}{ Tumor grade } \\
\hline Poor/moderate ${ }^{2}$ & 28 & $15(54)$ & NS & 1 (referent) \\
\hline Well & 48 & $29(60)$ & & $1.2(0.6-2.2)$ \\
\hline Unknown & 3 & & & \\
\hline \multicolumn{5}{|l|}{ Recurrent disease } \\
\hline $\mathrm{No}^{2}$ & 34 & $4(12)$ & $<0.0001$ & 1 (referent) \\
\hline Yes & 17 & $14(82)$ & & $15.2(4.2-54.6)$ \\
\hline Never disease free ${ }^{3}$ & 28 & $27(96)$ & & \\
\hline
\end{tabular}

$H P V=$ human papillomavirus; $H R=$ hazard ratio; $\mathrm{Cl}=$ confidence interval. ${ }^{1}$ According to the log rank test. ${ }^{2}$ Reference group for HR calculation. For exposure categories, the unexposed were chosen as the reference group. For the other categories the first category was chosen as the reference group. ${ }^{3}$ One patient died of other causes 
TABLE 3. MULTIVARIATE ANALYSIS, ACCORDING TO COX PROPORTIONAL HAZARD REGRESSION ANALYSIS, OF THE POPULATION CHARACTERISTICS RELATED TO SURVIVAL OUTCOME.

\begin{tabular}{lccc}
\hline Characteristic & HR & $95 \% \mathrm{Cl}$ & P-value \\
\hline HPV status: negative vs. positive & 2.00 & $0.9-4.2$ & 0.08 \\
Smoking: yes vs. no & 5.53 & $1.3-23.6$ & 0.02 \\
Alcohol use: yes vs. no & 0.52 & $0.3-1.0$ & 0.06 \\
Tumor size: T3-4 vs. T1-2 & 2.60 & $1.4-4.9$ & 0.01
\end{tabular}

$H P V=$ human papillomavirus; $H R=$ hazard ratio; $\mathrm{Cl}=$ confidence interval

\section{Discussion}

In the head and neck region oncogenic HPV 16 appears to be predominantly detected in lesions developing in the oropharynx, in particular the tonsil6-8,10,12,17,18,44. In this report we have applied a highly sensitive FISH procedure to 81 TSCC, enabling HPV DNA detection up to the level of a single copy per cell nucleus, and discrimination between replicative (episomal) and integrated virus on the basis of the nuclear staining pattern. Using this approach $41 \%$ of these tumors exhibited nuclear HPV signals indicative for viral integration into the cellular genome. These tumors furthermore demonstrated accumulation of the CDK4/6 inhibitor p16 INK4A. HPV integration was also very strongly associated with specific clinico-pathological characteristics, as well as with absence of extravagant tobacco and/or alcohol consumption. Interestingly, the presence of HPV 16 proved to be a strong independent predictor of favorable outcome in these non-smokers. Tobacco use on the other hand was the most important predictor of a reduced survival rate in patients with TSCC.

\section{HPV 16 is integrated in TSCC}

Data concerning the physical status of HPV in TSCC are so far limited and confusing, ranging from virus being present only in the integrated or only in the episomal form $18,24,25,45$. Our FISH results reveal that all HPV 16-positive tumors show integrated virus, predominantly seen as 1 punctate signal per tumor cell nucleus. In 7 HPV-positive cases tumor cells harbored 2 punctate nuclear signals or more signals of different size and intensity. The former FISH signal pattern is indicative for two integration sites in the cellular genome or for a pair of chromosomes with 
a single integration site, whereas the latter pattern most probably point to signals composed of integrated HPV DNA together with transcribed viral RNA. It is important to emphasize that RNA can contribute to the observed FISH signal ${ }^{46}$, but that the protocol used in this study is optimal for unmasking integrated HPV DNA. Preliminary data on 2 mucosal dysplasia and 4 carcinoma in situ lesions identified adjacent to the 33 TSCC specimens also showed punctate FISH signals indicative for integrated HPV 16. Besides integration, $33 \%$ of the TSCC also contained areas with tumor cells showing diffuse nuclear staining indicative for the presence of episomal HPV. Studies on the physical status of HPV using PCR assays, such as the amplification of papillomavirus oncogene transcript (APOT) and the E2/E6 real-time PCR assay, have also shown HPV to be present predominantly in the integrated form ${ }^{16,25}$. These and our findings support the hypothesis that transition of oncogenic HPV DNA from the episomal to the integrated form, as has been shown to be an important factor in uterine cervical tumorigenesis ${ }^{19,21,47}$, might also be crucial for progression towards malignancy in TSCC. The finding of mainly episomal HPV 16 in TSCC by Mellin et al. ${ }^{24}$ using restriction enzyme cleavage, ligation and PCR (rliPCR) is in contrast with this perspective. However, the difficulty of the rliPCR approach to produce the required extreme long PCR products that indicate viral integration in primary TSCC, as well as the presence of episomal virus in tumor parts or precursor lesions adjacent to or included in the cancer, may explain the data of these authors.

\section{P16 ${ }^{\text {INK4A }}$ overexpression in TSCC is associated with HPV integration}

Approximately $80 \%$ of HNSCC show inactivation of $\mathrm{p} 16^{\text {INK } 4 \mathrm{~A}}$ as a result of (epi)genetic alterations in this tumor suppressor gene $2,3,48$, but in our study about half of the tonsillar carcinomas showed an overexpression of $\mathrm{p} 16^{\text {INK4A }}$. Of the HPV 16-positive carcinomas all but one showed this overexpression, whereas only a few of the HPV 16-negative carcinomas showed accumulation of $\mathrm{p} 16^{\mathrm{INK} 4 \mathrm{~A}}$. This is in agreement with earlier reports on oropharyngeal cancers ${ }^{26,27,45,49}$. The strong correlation between HPV 16 positivity and $\mathrm{p} 16^{\mathrm{INK} 4 \mathrm{~A}}$ overexpression further supports the statement that the accurate and relatively simple immunohistochemical detection of $\mathrm{p} 16^{1 \mathrm{NK} 4 \mathrm{~A}}$ is a good marker to identify HPV-positive lesions in tonsillar carcinogenesis and may be used in routine practice. The finding of $\mathrm{p} 16^{\mathrm{INK} 4 \mathrm{~A}}$ overexpression in HPV-negative tumors may be the result of oncogene-driven cellular senescence ${ }^{50}$ or infection with other viruses that downregulate $\mathrm{pRb}^{51,52}$. 
HPV integration correlates with poor tumor differentiation grade and metastatic progression at relatively small tumor size

In our study, the presence of tumor-associated HPV significantly correlated with a poor tumor differentiation grade, which is in agreement with other studies $2,8,53$. HPVnegative carcinomas more often showed to be well differentiated and keratinizing, which was very significantly associated with tobacco use $(p=0.007)$. Whether or not this keratinization process induced by smoking might have a protective effect on HPV infection in, e.g., the oropharynx is unclear.

Patients with HPV 16-positive tumors presented significantly more often with the initial complaint of a swelling in the neck. This is rather surprising since both HPV-positive and -negative tumors showed comparable percentages of detected lymph node metastases. An explanation for this different presentation might be the significantly smaller primary tumor size $(p=0.024)$ at the time of diagnosis, leading to less local problems in the HPV-positive patients. Another explanation may be better health awareness in patients with HPV 16-positive tumors as reflected in significantly less alcohol and tobacco abuse. The significantly smaller HPV-positive tumors were accompanied by slightly more regional metastases compared to the HPV-negative tumors, which might suggest that HPV-positive tumors have a tendency to metastasize early.

\section{Non-smokers exhibit a markedly improved survival rate in HPV-associated} TSCC

We found that patients with HPV 16-positive tumors had a significantly better disease-specific and overall survival compared to patients with HPV 16-negative tumors, which is in accordance with most recent studies focusing on oropharyngeal carcinomas and oncogenic HPV types $8,24,29,30,31,54,55$. It has been suggested that this better survival outcome might result from a better response to radiation therapy ${ }^{56}$, as a result of induction of apoptosis by intact p53, as well as from a much lower chance of developing a second primary tumor ${ }^{8}$, because patients with HPV-positive tumors show often low or no tobacco and alcohol intake and HPV infection tends to be focal. Our data are in agreement with these suggestions, because we noticed a significantly lower tobacco and alcohol intake as well as a lower percentage of (loco) regional recurrences in HPV-positive tumor patients, and found only second primary tumor development in the HPV-negative patient group. 


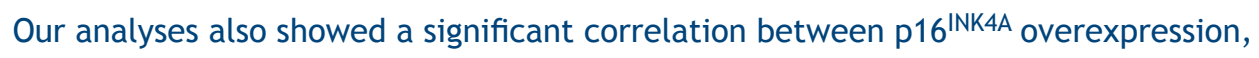
less or absent smoking, with or without alcohol intake, tumor size $<4 \mathrm{~cm}$, and less recurrent disease on the one hand, and prolonged survival on the other. Because these factors are also significantly correlated to HPV 16 positivity, they could artificially influence the survival data of the HPV 16-positive patients. Multivariate analyses adjusting for HPV, smoking, alcohol consumption and tumor size showed that smoking and tumor size were the most important factors determining survival outcome in the present study population. After these adjustments, HPV 16 positivity showed a strong tendency towards a better prognosis. Because of the relatively small study size and small number of patients in the subcategories of some of the covariates included in the multivariate analysis, additional studies are needed to confirm our results. Unlike earlier reports $29,31,57$, we show that gender, age, alcohol consumption and lymph node status do not influence survival outcome. The latter parameter has also been found an unreliable prognostic indicator by others ${ }^{58,59}$, which most probably is due to a higher percentage of HPV-positive, non-smoking patients with a better survival in the lymph node-positive group.

From our study we conclude that 1) HPV 16 integration is present in approximately $40 \%$ of TSCC, 2) p $16^{\text {INK } 4 \mathrm{~A}}$ immunostaining is significantly associated with HPV-positive TSCC and may function as a surrogate marker for HPV detection, 3) the presence of HPV in TSCC correlates significantly with low amounts of tobacco and alcohol intake, poor differentiation grade, small tumor size, presence of a swelling in the neck due to local metastases and a decreased recurrence rate, and 4) particularly non-smoking patients with HPV-containing TSCC show a remarkably better disease-specific survival rate.These data are of diagnostic and therapeutic importance, since interventions are dependent on clinical outcome parameters, and an improved understanding of the role of HPV in the carcinogenesis of TSCC may offer strategies for disease prevention.

\section{Acknowledgements}

Supported in part by the Medical Research Foundation "Profileringsfonds", Grant number: PF126, and the Research Foundation of the ENT Department, University Hospital Maastricht, Maastricht, The Netherlands. 
We thank Dr. J.P. Klussmann (Department of Otorhinolaryngology and Head and Neck Surgery, University of Cologne, Germany) and Dr. S. J. Weissenborn (Institute for Virology, University of Cologne, Germany) for helpful suggestions, and Ms. S.M.H. Claessen (Department of Molecular Cell Biology, University of Maastricht, The Netherlands) for outstanding technical support.

\section{References}

1. Parkin DM, Pisani P, Ferlay J. Estimates of the worldwide incidence of eighteen major cancers in 1985. Int J Cancer 1993;54:594-606.

2. Forastiere A, Koch W, Trotti A, Sidransky D. Head and neck cancer. N Engl J Med 2001;345:18901900.

3. Mao L, Hong WK, Papadimitrakopoulou. Focus on head and neck cancer. Cancer Cell 2004;5:311-6.

4. Frisch $\mathrm{M}$, Hjalgrim $\mathrm{H}$, Jaeger $\mathrm{AB}$, Biggar RJ. Changing patterns of tonsillar squamous cell carcinoma in the United States. Cancer Causes Control 2000;11:489-95.

5. Hafkamp HC, Manni JJ, Speel EJ. Role of human papillomavirus in the development of head and neck squamous cell carcinomas. Acta Otolaryngol 2004;124:520-26.

6. Paz IB, Cook N, Odom-Maryon T, Xie Y, Wilczynski SP. Human papillomavirus (HPV) in head and neck cancer. An association of HPV 16 with squamous cell carcinoma of Waldeyer's tonsillar ring. Cancer 1997;79:595-604.

7. McKaig RG, Baric RS, Olshan AF. Human papillomavirus and head and neck cancer: epidemiology and molecular biology. Head Neck 1998;20:250-65.

8. Gillison ML, Koch WM, Capone RB, Spafford M, Westra WH, Wu L, Zahurak ML, Daniel RW, Viglione M, Symer DE, Shah KV, Sidransky D. Evidence for a causal association between human papillomavirus and a subset of head and neck cancers. J Natl Cancer Inst 2000;92:709-20.

9. van Houten VM, Snijders PJ, van den Brekel MW, Kummer JA, Meijer CJ, van Leeuwen B, Denkers F, Smeele LE, Snow GB, Brakenhoff RH. Biological evidence that human papillomaviruses are etiologically involved in a subgroup of head and neck squamous cell carcinomas. Int J Cancer 2001;93:232-5.

10. Snijders PJ, Cromme FV, van den Brule AJ, Schrijnemakers HF, Snow GB, Meijer CJ, Walboomers JM. Prevalence and expression of human papillomavirus in tonsillar carcinomas, indicating a possible viral etiology. Int J Cancer 1992;51:845-50.

11. Schwartz SM, Daling JR, Doody DR, Wipf GC, Carter JJ, Madeleine MM, Mao EJ, Fitzgibbons ED, Huang S, Beckmann AM, McDougall JK, Galloway GK. Oral cancer risk in relation to sexual history and evidence of human papillomavirus infection. J Natl Cancer Inst 1998;90:1626-36.

12. Mork J, Lie AK, Glattre E, Hallmans G, Jellum E, Koskela P, Moller B, Pukkala E, Schiller JT, Youngman L, Lehtinen M, Dillner J. Human papillomavirus infection as a risk factor for squamous-cell carcinoma of the head and neck. N Engl J Med 2001;344:1125-31.

13. Frisch M, Biggar RJ. Aetiological parallel between tonsillar and anogenital squamous-cell carcinomas. Lancet 1999;354:1442-3.

14. Franceschi S, Munoz N, Bosch XF, Snijders PJ, Walboomers JM. Human papillomavirus and cancers of the upper aerodigestive tract: a review of epidemiological and experimental evidence. Cancer Epidemiol Biomarkers Prev 1996;5:567-75.

15. Franceschi S, Munoz N, Snijders PJ. How strong and how wide is the link between HPV and oropharyngeal cancer? Lancet 2000;356:871-2.

16. Wiest T, Schwarz E, Enders C, Flechtenmacher C, Bosch FX. Involvement of intact HPV16 E6/E7 gene expression in head and neck cancers with unaltered p53 status and perturbed pRb cell cycle control. Oncogene 2002;21:1510-7. 
17. Klussmann JP, Weissenborn SJ, Wieland U, Dries V, Kolligs J, Jungehuelsing M, Eckel HE, Dienes HP, Pfister HJ, Fuchs PG. Prevalence, distribution, and viral load of human papillomavirus 16 DNA in tonsillar carcinomas. Cancer 2001;92:2875-84.

18. Hafkamp HC, Speel EJ, Haesevoets A, Bot FJ, Dinjens WN, Ramaekers FC, Hopman AH, Manni JJ. A subset of head and neck squamous cell carcinomas exhibits integration of HPV 16/18 DNA and overexpression of p16INK4A and p53 in the absence of mutations in p53 exons 5-8. Int $\mathrm{J}$ Cancer 2003;107:394-400.

19. zur Hausen H. Papillomaviruses and cancer: from basic studies to clinical application. Nat Rev Cancer 2002;2:342-50.

20. Ziegert C, Wentzensen N, Vinokurova S, Kissljov F, Einenkel J, Hoeckel M, van Knebel Doeberitz M. A comprehensive analysis of HPV integration loci in anogenital lesions combining transcript and genome-based amplification techniques. Oncogene 2003;22:3977-84.

21. Hopman AH, Smedts F, Dignef W, Ummelen M, Sonke G, Mravunac M, Vooijs GP, Speel EJ, Ramaekers FC. Transition of high-grade cervical intraepithelial neoplasia to micro-invasive carcinoma is characterized by integration of HPV $16 / 18$ and numerical chromosome abnormalities. $J$ Pathol 2004;202:23-33.

22. Munger K, Scheffner M, Huibregtse JM, Howley PM. Interactions of HPV E6 and E7 oncoproteins with tumour suppressor gene products. Cancer Surv 1992;12:197-217.

23. Klaes R, Friedrich T, Spitkovsky D, Ridder R, Rudy W, Petry U, Dallenbach-Hellweg G, Schmidt D, von Knebel Doeberitz M. Overexpression of p16(INK4A) as a specific marker for dysplastic and neoplastic epithelial cells of the cervix uteri. Int J Cancer 2001;92:276-84.

24. Mellin H, Dahlgren L, Munck-Wikland E, Lindholm J, Rabbani H, Kalantari M, Dalianis T. Human papillomavirus type 16 is episomal and a high viral load may be correlated to better prognosis in tonsillar cancer. Int J Cancer 2002;102:152-8.

25. Koskinen WJ, Chen RW, Leivo I, Makitie A, Back L, Kontio R, Suuronen R, Lindqvist C, Auvinen E, Molijn A, Quint JG, Vaheri A, et al. Prevalence and physical status of human papillomavirus in squamous cell carcinomas of the head and neck. Int J Cancer 2003;107:401-6.

26. Klaes R, Benner A, Friedrich T, Ridder R, Herrington S, Jenkins D, Kurman RJ, Schmidt D, Stoler M, van Knebel Doeberitz M. p16INK4a immunohistochemistry improves interobserver agreement in the diagnosis of cervical intraepithelial neoplasia. Am J Surg Pathol 2002;26:1389-99.

27. Klussmann JP, Gultekin E, Weissenborn SJ, Wieland U, Dries V, Dienes HP, Eckel HE, Pfister HJ, Fuchs PG. Expression of p16 protein identifies a distinct entity of tonsillar carcinomas associated with human papillomavirus. Am J Pathol 2003;162:747-53.

28. Bernabe RD, Williams SF, Quintana RA. P14 ARF interferes with HPV oncoproteins biological activity in head and neck cancer. Proc AACR 2004;45:427-8 (abstract 1862).

29. Ritchie JM, Smith EM, Summersgill KF, Hoffman HT, Wang D, Klussmann JP, Turek LP, Haugen TH. Human papillomavirus infection as a prognostic factor in carcinomas of the oral cavity and oropharynx. Int J Cancer 2003;104:336-44.

30. Sisk EA, Soltys SG, Zhu S, Fisher SG, Carey TE, Bradford CR. Human papillomavirus and p53 mutational status as prognostic factors in head and neck carcinoma. Head Neck 2002;24:841-9.

31. Schwartz SR, Yueh B, McDougall JK, Daling JR, Schwartz SM. Human papillomavirus infection and survival in oral squamous cell cancer: a population-based study. Otolaryngol Head Neck Surg 2001;125:1-9.

32. Clayman GL, Stewart MG, Weber RS, el-Naggar AK, Grimm EA. Human papillomavirus in laryngeal and hypopharyngeal carcinomas. Relationship to survival. Arch Otolaryngol Head Neck Surg 1994;120:743-8.

33. Strome SE, Savva A, Brissett AE, Gostout BS, Lewis J, Clayton AC, McGovern R, Weaver AL, Persing D, Kasperbauer JL. Squamous cell carcinoma of the tonsils: a molecular analysis of HPV associations. Clin Cancer Res 2002;8:1093-100.

34. Haraf DJ, Nodzenski E, Brachman D, Mick R, Montag A, Graves D, Vokes EE, Weichselbaum RR. Human papilloma virus and p53 in head and neck cancer: clinical correlates and survival. Clin Cancer Res $1996 ; 2: 755-62$. 
35. Li W, Thompson CH, Cossart YE, O’Brien CJ, McNiel CB, Scolyer RA, Rose BR. The expression of key cell cycle markers and presence of human papillomavirus in squamous cell carcinoma of the tonsil. Head Neck 2004;26:1-9.

36. Shanmugaratnam S. Histologic typing of tumors of the upper respiratory tract and ear. Geneva (Switserland): World Health Organization 1991.

37. Hopman AH, Ramaekers FC, Speel EJ. Rapid synthesis of biotin-, digoxigenin-, trinitrophenyl-, and fluorochrome-labeled tyramides and their application for In situ hybridization using CARD amplification. J Histochem Cytochem 1998;46:771-7.

38. Cooper K, Herrington CS, Stickland JE, Evans MF, McGee JO. Episomal and integrated human papillomavirus in cervical neoplasia shown by non-isotopic in situ hybridisation. J Clin Pathol 1991;44:990-6.

39. Baay MFD, Quint WGV, Koudstaal J, Hollema H, Duk JM, Burger MP, Stoltz E, Herbrink P. Comprehensive study of several general and type-specific primer pairs for detection of human papillomavirus DNA by PCR in paraffin-embedded cervical carcinomas. J Clin Microbiol 1996;34:745-7.

40. Wieland U, Ritzkowsky A, Stoltidis M, Weissenborn S, Stark S, Ploner M, Majewski S, Jablonska S, Pfister HJ, Fuchs PJ. Communication: papillomavirus DNA in basal cell carcinomas of immunocompetent patients: an accidental association? J Invest Dermatol 2000;115:124-8.

41. Van den Brule AJ, Pol R, Fransen-Daalmeijer N, Schouls LM, Meijer CJ, Snijders PJ. GP5+/6+ PCR followed by reverse line blot analysis enables rapid and high-throughput identification of human papillomavirus genotypes. J Clin Microbiol 2002;40:779-87.

42. Kaplan E, Meier P. Nonparametric estimation from incomplete observations. J Am Stat Assoc 1958;53:457-81.

43. Mantel N, Haenszel W. Statistical aspects of the analysis of data from retrospective studies of disease. J Natl Cancer Inst 1959;22:719-48

44. Fouret P, Monceaux G, Temam S, Lacourreye L, St Guily JL. Human papillomavirus in head and neck squamous cell carcinomas in nonsmokers. Arch Otolaryngol Head Neck Surg 1997;123:513-6.

45. Begum S, Cao D, Gillison M, Zahurak M, Westra WH. Tissue distribution of human papillomavirus 16 DNA integration in patients with tonsillar carcinoma. Clin Cancer Res 2005;11:5694-9.

46. Hopman AHN, Kamps M, Smedts F, Speel EJM, Herrington CS, Ramaekers FCS. HPV in situ hybridization: impact of different protocols on the detection of integrated HPV. Int J Cancer 2005;115:419-28.

47. Wentzensen N, Vinokurova S, Von Knebel Doeberitz M. Systematic review of genomic integration sites of human papillomavirus genomes in epithelial dysplasia and invasive cancer of the female lower genital tract. Cancer Res 2004;64:3878-84.

48. Reed AL, Califano J, Cairns P, Westra WH, Jones RM, Koch W, Ahrendt S, Eby Y, Sewell D, Nawroz H, Bartek J, Sidransky D. High frequency of p16 (CDKN2/MTS-1/INK4A) inactivation in head and neck squamous cell carcinoma. Cancer Res 1996;56:3630-3.

49. Weinberger PM, Yu ZY, Haffty BG, Kowalski D, Harigopal M, Brandsma D, Sasaki C, Joe J, Camp RL, Rimm DL, Psyrri A. Molecular Classification identifies a subset of human papillomavirus-associated oropharyngeal cancers with favorable prognosis. J Clin Oncol 2006;24:736-47.

50. Michaloglou C, Vredeveld LCW, Soengas MS, Denoyelle C, Kuilman T, van der Horst CM, Majoor DM, Shay JW, Mooi JW, Peeper DS. BRAF ${ }^{\mathrm{E} 600}$-associated senescence-like cell cycle arrest of human naevi. Nature 2005;436:720-4.

51. Castillo JP, Kowalik TF. Human cytomegalovirus immediate early proteins and cell growth control. Gene 2002;290:19-34.

52. Helt A-M, Galloway DA. Mechanisms by which DNA tumor virus oncoproteins target Rb family of pocket proteins. Carcinogenesis 2003;24:159-69.

53. Wilczynski SP, Lin BT, Xie Y, Paz IB. Detection of human papillomavirus DNA and oncoprotein overexpression are associated with distinct morphological patterns of tonsillar squamous cell carcinoma. Am J Pathol 1998;152:145-56.

54. Li W, Thompson CH, O’Brien CJ, McNiel EB, Scolyer RA, Cossart YE, Veness MJ, Walker DM, Morgan GJ, Rose BR. Human papillomavirus positivity predicts favourable outcome for squamous carcinoma of the tonsil. Int J Cancer 2003;106:553-8. 
55. Chiba I, Shindoh M, Yasuda M, Yamazaki Y, Amemiya A, Sato Y, Fujinaga K, Notani K, Fukada H. Mutations in the p53 gene and human papillomavirus infection as significant prognostic factors in squamous cell carcinomas of the oral cavity. Oncogene 1996;12:1663-8.

56. Lindel K, Beer KT, Laissue J, Greiner RH, Aebersold DM. Human papillomavirus positive squamous cell carcinoma of the oropharynx: a radiosensitive subgroup of head and neck carcinoma. Cancer 2001;92:805-13.

57. Genden EM, Ferlito A, Scully C, Shaha AR, Higgins K, Rinaldo A. Current management of tonsillar cancer. Oral Oncol 2003;39:337-42.

58. Al-Abdulwahed S, Kudryk W, Al-Rajhi N. Carcinoma of the tonsil: prognostic factors. J Otolaryngol 1996;26:196-9.

59. Friesland S, Fernberg JO, Lundell G, Munck-Wikland E, Strander H, Lewensohn R. Prognostic impact of complete remission after preoperative irradiation of tonsillar carcinoma: a retrospective analysis of the radiumhemmet data, 1980-1995. Int J Radiat Oncol Biol Phys 1999;45:1259-66. 


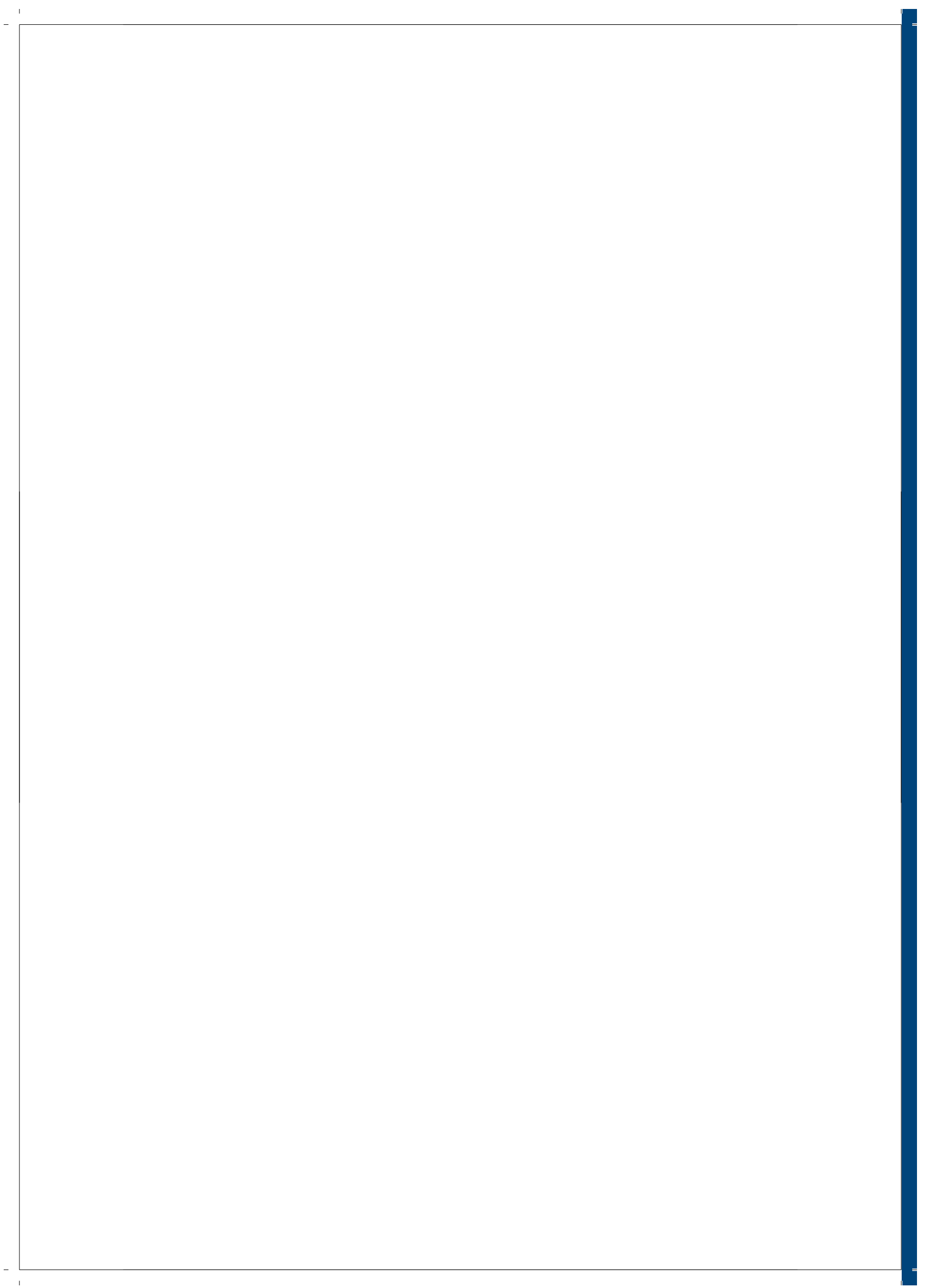




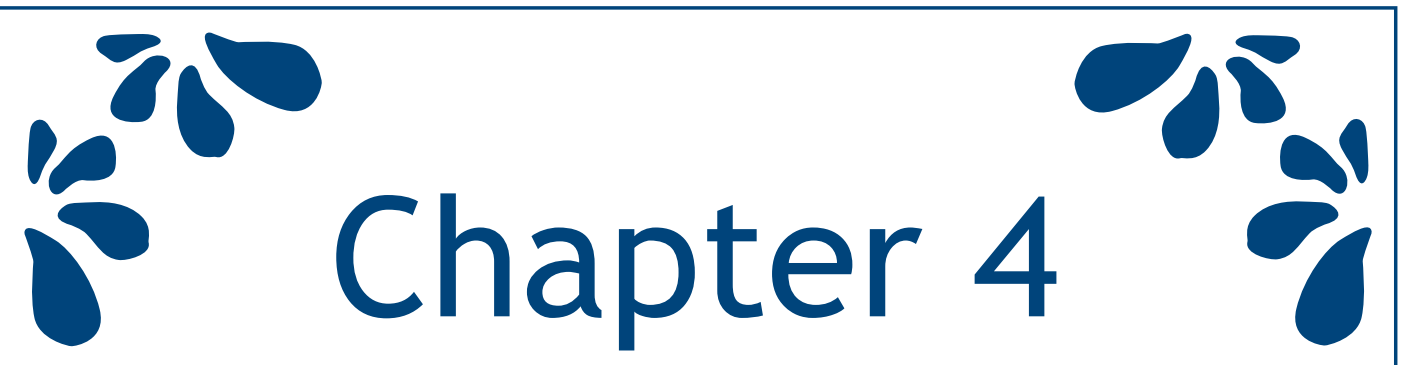

$\mathrm{p} 16^{\text {INK4A }}$ overexpression is frequently detected in tumor-free tonsil tissue without association with HPV

Boris Klingenberg, Harriët C. Hafkamp, Annick Haesevoets, Johannes J. Manni, Piet J. Slootweg, Soenke J. Weissenborn, Jens P Klussmann, and Ernst-Jan M Speel 


\begin{abstract}
Oncogenic human papillomavirus (HPV) type 16 has been strongly associated with tonsillar squamous cell carcinomas (TSCC) and appears to be of prognostic significance. Because HPV-positive TSCC also accumulate p16 INK4A, this cyclindependent kinase inhibitor has been proposed as a potential biomarker for HPV in clinical diagnosis. Data on HPV prevalence and the value of $\mathrm{p} 16^{\mathrm{INK} 4 \mathrm{~A}}$ overexpression to predict its presence in tumor-free tonsil tissue, however, are scarce. We used immunohistochemistry to detect $\mathrm{p} 16^{\mathrm{INK} 4 \mathrm{~A}}$ overexpression in sections taken from formalin-fixed, paraffin-embedded tumor-free tonsil tissue of 262 patients. They were treated for non-oncologic reasons (snoring or chronic/recurrent tonsillitis). Genomic DNA isolated from these tissues was subjected to HPV-specific PCR analysis. p $16^{\mathrm{INK} 4 \mathrm{~A}}$ immunostaining was detected in $28 \%$ of the samples in both crypt epithelium (49/177) and germinal centers of the lymphoid tissue (52/187), which was significantly associated with each other $(p<0.0001)$. No staining was observed in superficial squamous cell epithelium. HPV-specific PCR analysis detected HPV 16 and 18 in 2/195 cases (1\%), which however were negative in FISH analysis and discrepant in $16^{\mathrm{INK} 4 \mathrm{~A}}$ immunostaining. In conclusion, no proof was found for HPV presence in tumor-free tonsil tissue, despite increased $\mathrm{p} 16^{\mathrm{INK} 4 \mathrm{~A}}$ expression in a quarter of tonsil tissues. Other mechanisms than HPV infection are therefore implicated in upregulation of $\mathrm{p} 16^{\mathrm{INK} 4 \mathrm{~A}}$.
\end{abstract}




\section{Introduction}

On a worldwide scale head and neck squamous cell carcinoma (HNSCC) contributes $6.5 \%$ of annual cancer cases ${ }^{1}$. Up to $90 \%$ of HNSCC occur in patients with a high intake of tobacco and alcohol ${ }^{2,3}$. Besides tobacco smoking and alcohol consumption, many studies have confirmed that oncogenic human papillomavirus (HPV) is another risk factor for HNSCC, especially oropharyngeal carcinomas, including those arising from Waldeyers ring ${ }^{4-10}$. HPV is generally known for its major role in the development of uterine cervical and anogenital cancer ${ }^{11,12,13}$. However, patients with HPV-associated anogenital cancers also show an increased risk for developing tonsillar squamouscell carcinoma (TSCC) $)^{14,15}$. Recently, an epidemiological study showed that the proportion of potentially HPV-related HNSCC have increased over the last decades, probably because of changing sexual behaviors ${ }^{16}$.

HPV-positive HNSCC are more and more considered to be a different tumor entity, because of pronounced clinical and molecular differences with their HPVnegative counterparts. For example, HPV-positive tumors often present as poorly differentiated, aggressively growing tumors already metastasized to the lymph nodes, despite a relatively favorable prognosis ${ }^{17,18}$. At the molecular level these tumors show, amongst others, functional inactivation of the p53 and pRb tumor suppressor proteins by the HPV-derived oncoproteins E6 and E7, resulting in downregulation of p53, pRb, and cyclin D1 and a strong up-regulation of cyclin-dependent kinase inhibitors $\mathrm{p} 16^{\mathrm{INK} 4 \mathrm{~A}}$ and $\mathrm{p} 21^{\mathrm{CIF} 1 / \mathrm{WAF} 1}$ as well as the $\mathrm{p} 14^{\mathrm{ARF}}$ protein ${ }^{9,12,19-22}$. HPVnegative tumors, in contrast, often show inactivation of $\mathrm{p} 16^{\mathrm{INK} 4 \mathrm{~A}}$, p53 overexpression as a result of gene mutations, cyclin D1 gene amplification and overexpression, as well as EGFR accumulation ${ }^{23-26}$. Because of its very strong association with HPV-positive HNSCC $^{9,27,28} \mathrm{p}^{16^{\text {INK4A }}}$ overexpression has recently been proposed as a surrogate

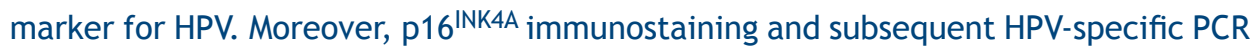
and/or FISH have been recommended to identify HNSCC with biologically associated HPV 28,29.

The reason for the strong association of HPV with particularly TSCC and thus the susceptibility of tonsils for HPV infection remains unclear, although the easy viral accessibility of the invaginated, monolayered crypt epithelium and the presence of cytokines produced by the lymphoid tissue to stimulate viral transcription and cellular transformation have been suggested as explanations ${ }^{8,14,30,31}$. A recent study by Kim et al. ${ }^{32}$ further suggested HPV-positive TSCC to originate predominantly 
from the crypts by microscopic detection of specific growth patterns. Data on 1) the prevalence of oncogenic HPV in normal mucosa of tonsils of healthy persons as well as tonsils with carcinomas, 2) the earliest stages of infection and 3) its role in promoting tonsillar carcinogenesis, however, are still scarce.

So far, several studies have reported data on the detection of HPV DNA in normal, tumor-free head and neck mucosa samples (see Table 1). Most often these studies used non-invasive cell sampling methods, such as oral rinsing and cytological scraping or brushing, in order to test for the presence of HPV DNA by means of PCR. A disadvantage of these sampling methods is that they mainly collect superficial epithelial cells and that mostly no additional tests were performed for validation. In addition, a large multicenter study provided evidence that HPV DNA in oral exfoliated cells did not associate with risk for HNSCC or with HPV DNA detection in oral biopsy specimens ${ }^{33}$. Therefore, a more appropriate approach to study HPV presence in tonsil tissue is the use of tissue sections obtained either by biopsy or tonsillectomy in combination with PCR, FISH or immunostaining for $\mathrm{p} 16^{\mathrm{INK} 4 \mathrm{~A}}$. Overexpression of this protein has been proposed as a specific biomarker for the presence of HPV in both the uterine cervix as well as the oropharynx $x^{9,10,34,35}$.

The aim of this study was to assess the prevalence and site of p16 1NK4A overexpression, as a biomarker for high risk HPV, in tumor-free tonsil tissue of a population presenting in the clinic for non-oncologic reasons. In addition, p16 INK4A overexpression was correlated with HPV detection by means of HPV-specific PCR and with clinical data, such as age, gender, alcohol consumption and/or tobacco smoking.

\section{Materials and methods}

\section{Study population and tissue selection}

Formaldehyde-fixed and paraffin-embedded tonsil biopsies and resection material from 262 patients were selected from the archives of the Department of Pathology, Utrecht Medical Centre (UMC), The Netherlands. These individuals presented subsequently during 1997 and 1998 with chronic tonsillitis or snoring problems and underwent a tonsillectomy. Patients gave their informed consent to use tissue for research purposes and were asked to fill in a small questionnaire, concerning demographic data like age at presentation, gender, and alcohol consumption and 
tobacco smoking. The entire study was approved by the medical ethical committee of the UMC Utrecht. Full answered questionnaires were available from 143 (55\%) patients. On basis of these data, the male to female ratio was 2:1 (97 male and 46 female patients), the mean age was 29.2 years (range 12-70; $n=256$ )), 135 patients were classified as daily tobacco smokers ( $\geq 1$ cigarette, pipe, and/or cigar per day) and 122 as non-smokers (never smoker or former smoker, which are those who had stopped smoking more than 10 years before presentation), and 29 patients were classified as drinkers (consumption of $\geq 1$ whiskey equivalents per day ( 1 whiskey equivalent $\sim 10 \mathrm{~g}$ alcohol)) and 227 as non-drinkers (no whiskey equivalents per day). A series of $4 \mu \mathrm{m}$-thick sections were cut from the specimens to reclassify the tissue on basis of a HE staining, to immunohistochemically visualize p16 ${ }^{\text {INK } 4 A}$ and to isolate genomic DNA for beta-globin- and HPV-specific PCR.

\section{Immmunohistochemical staining of $\mathrm{p} 16^{\mathrm{INK} 4 \mathrm{~A}}$}

Four $\mu \mathrm{m}$ thick sections were deparaffinized in a series of xylol, $100 \%, 96 \%$ and $70 \%$ ethanol and incubated for $30 \mathrm{~min}$ at room temperature in $2 \% \mathrm{H}_{2} \mathrm{O}_{2}$ in methanol to quench endogenous peroxidase activity. Then the p16 $16^{\mathrm{INK} 4 \mathrm{~A}}$ research kit (Dako, Glostrup, Denmark), which contains the mouse monoclonal antibody E6H4 directed against $\mathrm{p} 16^{\mathrm{INK} 4 \mathrm{~A}}$ and a peroxidase-conjugated secondary visualization reagent, was used according to the manufacturer's instructions ${ }^{10}$. After diaminobenzidine visualization of peroxidase activity, sections were subsequently counterstained with hematoxylin and mounted with entellan (Merck, Darmstadt, Germany).

Three independent observers (B.K., P.S., E.S.) performed semi-quantitative evaluation of the slides and consensus was acquired. Moderate to strong nuclear and cytoplasmic staining in a small area of the tonsil tissue was considered as a region with p $16^{\mathrm{INK} 4 \mathrm{~A}}$ overexpression, whereas tissue with only faintly diffuse or no staining was considered to be $\mathrm{p} 16^{\text {INK4A }}$ negative. Controls consisted of tonsillar carcinoma specimens with or without associated $\mathrm{p} 16^{\mathrm{INK} 4 \mathrm{~A}}$ overexpression. Two sets of controls were used, i.e. substitution of the primary antibody by a monoclonal mouse lgG2a antibody to Aspergillus Niger, or omission of the primary antibody.

\section{DNA isolation, Polymerase chain reaction, and HPV typing}

From 253 of the 262 patient samples enough tissue material was available for genomic DNA extraction and PCR analysis. Tissues were processed with the QIAamp Tissue Kit (Qiagen, Hilden, Germany). Total cellular DNA was eluted with $250 \mu \mathrm{l}$ of AE-buffer (Qiagen) and $5 \mu$ were used in each polymerase chain reaction (PCR) analysis. 
B-Globin gene PCR was performed with all DNA samples to demonstrate that they contained sufficient DNA of adequate quality and were free of substances inhibitory to PCR (268 bp PCO4/GH20 PCR product) ${ }^{36}$. Negative controls, consisting of water or human placental DNA instead of patient samples, were included in each PCR run. As a result, 195 patient samples were subjected to HPV-specific PCR.

HPV sequences were detected by highly sensitive group-specific nested PCR protocols with degenerate primers A5/A10 and A6/A8 for HPV as described in ${ }^{37}$. PCR products $(5 \mu \mathrm{l})$ were separated on $2 \%$ agarose gels and visualized by ethidium bromide staining. For HPV typing internal biotinylated A6/A8-PCR products (270 bp) were hybridized with 37 type-specific digoxigenin-labeled oligonucleotide probes in an enzyme-immunoassay as previously described ${ }^{38,39}$.

Twenty-two moderate to strongly $\mathrm{p} 16^{\mathrm{INK} 4 \mathrm{~A}}$-positive and 6 negative tonsil samples $(n=28)$ were subsequently screened by PCR for the presence of adenovirus and cytomegalovirus DNA. Screening for adenoviral DNA was performed with the LightCycler system (Roche, Mannheim, Germany) as previously described ${ }^{40}$ and screening for cytomegaloviral DNA was performed with the RealArt CMV PCR Kit (Artus, Hamburg, Germany) according to the manufacturer's recommendation.

\section{Detection of HPV 16 and 18 DNA by FISH}

FISH was performed on $4-\mu \mathrm{m}$ thick tissue sections as described previously $10,41,42$. Briefly, sections were deparaffinized, pretreated with $85 \%$ formic acid/0.3\% $\mathrm{H}_{2} \mathrm{O}_{2}, 1$ $\mathrm{M} \mathrm{NaSCN}$ and $4 \mathrm{mg} / \mathrm{ml}$ pepsin, post-fixed in $1 \%$ formaldehyde in PBS, dehydrated in an ethanol series and hybridized with digoxigenin-labeled HPV 16- and 18-specific probes (PanPath, Amsterdam, The Netherlands) according to the manufacturer's instructions. After hybridization the preparations were washed stringently in $50 \%$ formamide, $2 \times S S C$ at $42^{\circ} \mathrm{C}$ ( 2 times $5 \mathrm{~min}$ ). The probes were detected by application of mouse anti-digoxin (Sigma, St. Louis, MO), peroxidase-conjugated rabbit antimouse and peroxidase-conjugated swine anti-rabbit (both Dako), and visualized by a peroxidase reaction using rhodamin-labeled tyramide ${ }^{43,44}$. Preparations were mounted in Vectashield (Vector Laboratories, Burlingame, CA) containing 4,6diamidino-2-phenyl indole (DAPI; Sigma: $0.2 \mathrm{~g} / \mathrm{ml}$ ). Microscope images were recorded with the Metasystems Image Pro System (black and white CCD camera; Sandhausen, Germany) mounted on top of a Leica DM-RE fluorescence microscope equipped with DAPI and rhodamin filters. 
Evaluation of nuclear hybridization signals was performed by 3 investigators (E.S., A.H. and B.K.) according to the criteria described by Cooper et al. ${ }^{45}$, i.e., punctate and/or diffuse signals throughout the nucleus indicating integrated and episomal HPV DNA, respectively. Controls included hybridizations on $70 \%$ ethanol suspensions and formaldehyde-fixed, paraffin-embedded sections of known HPV 16- and 18positive human cervical carcinoma cell lines (CaSki [ATCC; CRL1550; 500 integrated HPV 16 copies], HeLa [ATCC; CCL2; 20-50 integrated HPV 18 copies] and SiHa [ATCC; HTB35; 1-2 integrated HPV 16 copies]) to guarantee probe specificity, sensitivity and interpretation accuracy 42,46 , as well as hybridizations on tissue sections of cervical lesions with proven integration or episomal presence (replication) of HPV genomic DNA. Negative controls consisted of HPV PCR- and FISH-negative cell lines and tissue sections and hybridizations omitting the viral probe. In addition, the number of HPV integration spots per nucleus was scored in the tissue.

\section{Statistical analysis}

Clinical patient data were correlated with $\mathrm{p} 16^{\mathrm{INK} 4 \mathrm{~A}}$ overexpression in cross-tabulations using the Fisher exact test (two-tailed) and/or chi-square test. A significance level of $P \leq 0.05$ was chosen.

\section{Results}

\section{p16 ${ }^{\text {INK4A }}$ immunostaining}

All tonsil samples of 262 patients contained superficial squamous cell epithelium, whereas 187/262 cases harbored lymphoid follicles, 177 reticulated crypt epithelium and 176 both lymphoid follicles and crypt epithelium (Figure 1A). Moderate to strong diffuse cytoplasmic and nuclear p16 INK4A immunostaining was identified in crypt epithelium as focal staining generally involving nonkeratinizing cell groups and associated lymphocytes (49/177; 27.7\%) (Figures 1 B and D) and in scattered cells within germinal centers of lymphoid follicles (52/187; 27.8\%) (Figures $1 \mathrm{C}$ and E). In the germinal centers, particularly dendritic cells were positive for p16 ${ }^{\text {INK4A }}$ (Figure $1 \mathrm{E})$. Interestingly, the outcome of the $\mathrm{p} 16^{\mathrm{INK} 4 \mathrm{~A}}$ immunostaining in the crypt epithelium was strongly associated with that in the germinal centers (identical outcome in 139/176 cases; $p<0.0001)$. In 31/139 cases both tissue types simultaneously showed p16 ${ }^{\text {INK4A }}$ accumulation. None of the 262 samples showed any positive staining in 
the superficial squamous cell epithelium. No correlation was found when comparing the p16 $16^{\text {INK4A }}$ status with age (comparing groups $\leq$ or $>26$ years old, and $\leq$ or $>$ 35 years old), gender, and tobacco smoking and alcohol consumption using cross tabulations.
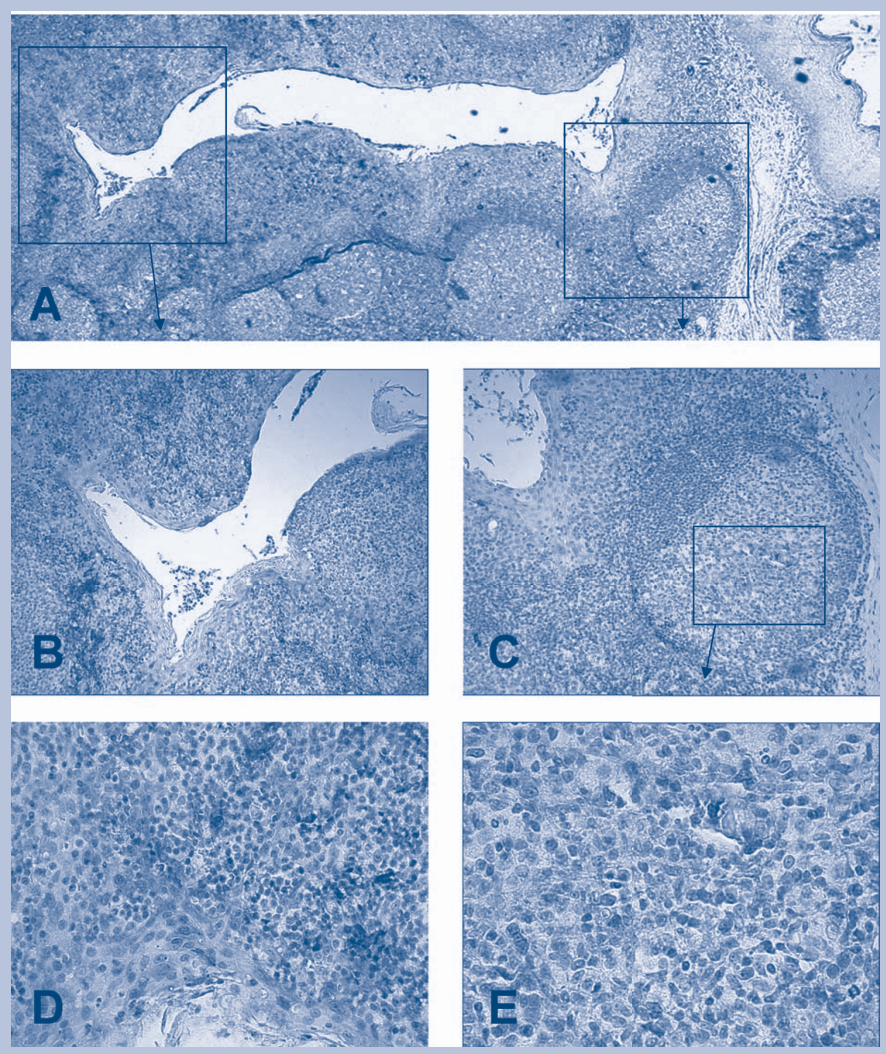

FIGURE 1. REPRESENTATIVE EXAMPLE OF P16INKAA IMMUNOHISTOCHEMISTRY IN A TUMORFREE NORMAL TONSIL FROM A PATIENT WITH TONSILLITIS. (A) Tissue overview showing strong immunostaining in both the reticulated crypt epithelium as well as in the follicular dendritic cells in one germinal center, whereas the superficial squamous cell epithelium is negative. (B) and (D) Enlargements of Figure 1A, showing focal and strong diffuse cytoplasmic and nuclear p16 1NK4A immunostaining in the crypt epithelium involving nonkeratinizing cell groups and associated lymphocytes. (C) and (E) Enlargements of Figure 1A, showing p16 1 NK4A accumulation in scattered cells within a germinal center of a lymphoid follicle. Nuclei were counterstained (dark) with hematoxylin. (see page 157 for color figure) 


\section{HPV detection}

Of the 253 DNA samples isolated from tonsil tissue, 195 proved to be positive for B-globin in the PCR analysis. In 2 of these cases HPV DNAs were identified, i.e. one case with HPV 16 and 18, and one case with HPV 16, 18 and 68 (data not shown). Only the former case was associated with strong p $16^{\mathrm{INK} 4 \mathrm{~A}}$ overexpression in the crypt epithelium as well as germinal centers. FISH analysis was unable to confirm the presence of oncogenic HPV type 16 and 18 in the 2 PCR-positive tonsil samples. No HPV DNA could be detected in the cell-nuclei of the different tissue areas, including

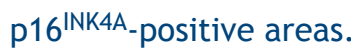

In order to examine if other viral infections underlie upregulation of p16 $6^{\text {INK4A }}$, 28 tonsil samples ( 22 moderate to strongly p16 ${ }^{\mathrm{INK} 4 \mathrm{~A}}$-positive and 6 negative samples) were analyzed for the presence of adenovirus and cytomegalovirus by PCR. No viral DNA was detected in these samples (data not shown).

\section{Discussion}

The palatine tonsils form the boundary between the oropharynx and the oral cavity, and function as the body's first immune defence system against bacteria, viruses and fungi entering through the mouth. These micro-organisms have been implicated in, for example, the induction of tonsillitis, a form of inflammation with reddening and reactive enlargement of lymphoid structures ${ }^{47}$. Besides this benign pathology, a large number of detailed studies have shown that the tonsils are also the preferential site for HPV-induced malignancy $6,7,8,9,10$. Up to $50 \%$ of TSCC have been associated with HPV, particularly type 16 . Interestingly, these tumors demonstrate overexpression of $\mathrm{p} 16^{1 \mathrm{NK} 4 \mathrm{~A}}$ amongst a variety of molecular and clinical characteristics different from their HPV-negative counterpart. Because this cyclindependent kinase inhibitor is mostly inactivated in the latter group, several studies have proposed $\mathrm{p} 16^{\mathrm{INK} 4 \mathrm{~A}}$ accumulation as a surrogate biomarker for HPV. Data on the presence of HPV in tumor-free tonsil tissue and on early molecular events during HPV-related carcinogenesis are however scarce. Therefore, we analyzed in this study a large series of tumor-free tonsil tissue samples for $\mathrm{p} 16^{\mathrm{INK} 4 \mathrm{~A}}$ overexpression and the presence of HPV-specific DNA. Despite positive p16 ${ }^{\text {INK4A }}$ immunostaining in $28 \%$ of samples, oncogenic HPV was only detected in 2 cases by PCR. Both cases were, in addition, negative in HPV 16/18-specific FISH analysis and only one of them 
exhibited $\mathrm{p} 16^{\mathrm{INK}} 4 \mathrm{~A}$ overexpression. These data indicate that $\mathrm{p} 16^{\mathrm{INK} 4 \mathrm{~A}}$ overexpression occurs frequently in tumor-free tonsil tissue without association with HPV, and thus should be used with caution as surrogate marker.

The very low percentage $(1 \%)$ of oncogenic HPV detected by PCR in this study is in agreement with other reports, describing frequencies of particularly HPV-type 16 and 18 ranging from $0-14 \%$ in tumor-free tonsil samples as well as normal tissue adjacent to TSCC (see Table 1). In the recent literature, however, additional tests have been proposed to firmly assess the biological association of the virus to the tissue, e.g. by detecting the presence and physical status of HPV

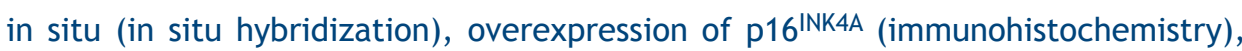
and/or upregulation of E6 or E7 mRNA transcripts (RT-PCR), for example after microdissection 9 , 10, 18, 29, 31. By applying both $\mathrm{p} 16^{\text {INK4A }}$ immunostaining on all and FISH on the two PCR-positive samples, we could not convincingly affirm HPV association in our series of tonsil tissues nor provide evidence for the presence of early stages of HPV-related carcinogenesis. Future studies should take into consideration the use of an appropriate combination of tests per sample to identify a clinically relevant HPV infection, and should focus on the analysis of primary tonsillar dysplasia or TSCC resection margins as more potential sources for this purpose.

In spite of the absence of HPV in tumor-free tonsil tissue, we detected p16 INK4A overexpression in more than a quarter of the tonsil samples, i.e. in the reticulated crypt epithelium and in follicular dendritic cells in one or more adjacent germinal centers of the surrounding lymphoid tissue. A marked finding was the highly significant association of immunostaining in both sites. In contrast, no p $16^{\text {INK } 4 \mathrm{~A}}$ expression was detected in the superficial squamous cell epithelium. No correlation was found between $\mathrm{p} 16^{\mathrm{INK} 4 \mathrm{~A}}$-positivity and clinical patient data, such as age, gender, alcohol consumption and/or tobacco smoking. P16 INK4A accumulation in tumor-adjacent crypt epithelium has been described previously by Klussmann et al. ${ }^{9}$, suggesting the presence of early stages of HPV infection. Our data, and recent data of Begum et al. ${ }^{27}$ on tumor-adjacent and contralateral tumor-free tonsil tissue, demonstrate that a meaningful HPV infection in most cases is absent in $\mathrm{p} 16^{\text {INK4A }}$-positive samples. A number of explanations might be considered for this decoupling of p16 INK4A accumulation and HPV positivity. First, there is the possibility that infection with other viruses contributes to the observed $\mathrm{p} 16^{1 \mathrm{NK} 4 \mathrm{~A}}$ overexpression by functionally inactivating $\mathrm{PRb}$ in a similar way as the HPV oncoprotein E7, pushing infected cells into proliferation. Examples are the major immediate early (IE) proteins of the 
herpesvirus CMV and the IE equivalents of small DNA viruses, such as adenovirus ${ }^{48,49}$. PCR analyses of our p16 ${ }^{\text {INK } 4 \mathrm{~A}}$-positive tumor-free tonsil samples, however, revealed no presence of these viruses. This, however, does not exclude infection by other virus types.

Second, p16 $16^{\mathrm{NK} 4 \mathrm{~A}}$ accumulation might be the result of cellular senescence and/or aging. On the one hand, a so-called premature senescence could be abruptly induced by functional overactivation of oncogenes including Ras, Raf, MEK and E2F, such as for example have been observed in benign melanocytic Spitz nevi ${ }^{50}$. To the best of our knowledge, evidence for this mechanism to occur in tonsillar lesions has not been described so far. On the other hand, stimuli such as telomere shortening, DNA damage, oxidative stress, and/or sustained mitogen stimulation, may result in so-called replicative senescence ${ }^{51}$. Both $\mathrm{p} 53$ and $\mathrm{p} 16^{\mathrm{INK} 4 \mathrm{~A}}$ are important mediators in this process, in which p53 responds strongest to these stresses. p16 ${ }^{\text {NK4A }}$, however, also appears to respond strongly to additional, yet not fully characterized, physiological stresses, leading to so-called physiological aging of tissue cells ${ }^{52,53}$. For example, metabolic stress due to an ad libitum-diet versus a caloric restricted diet was shown to induce tissue aging in combination with p16 ${ }^{\text {INK4A }}$ upregulation in different rat tissues, including lymph nodes and the spleen. Of particular interest, in addition, were immunostaining results in spleen tissue of aged mice, showing an increase in p $16^{1 \mathrm{NK} 4 \mathrm{~A}}$ expression in scattered cells of the follicular germinal centers ${ }^{53}$, similar to our results in the tonsillar lymphoid tissue. It is tempting to speculate that $\mathrm{p} 16^{\mathrm{INK} 4 \mathrm{~A}}$ accumulation, if observed in tumor-free tonsils, is also related to accelerated, physiological aging, e.g. induced by chronic infection of areas of crypt epithelium by bacteria, viruses or fungi as well as prolonged activation of amongst others interdigitating lymphocytes and antigen-presenting dendritic cells. The fact that our study population consists of patients with chronic tonsillitis and/or snoring problems, and $\mathrm{p} 16^{\mathrm{INK} 4 \mathrm{~A}}$ expression did not correlate to patient age, underscores this suggestion. 


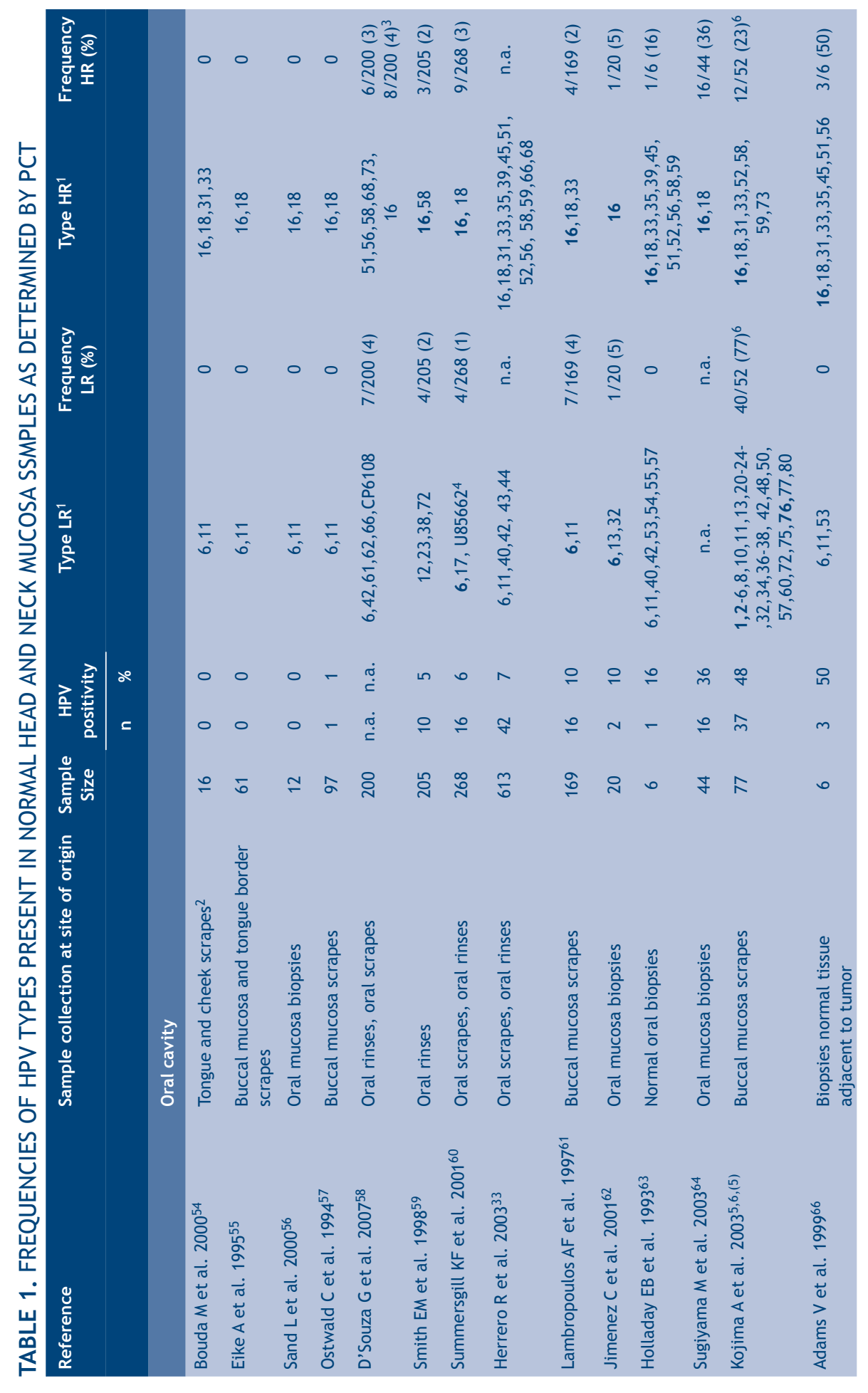




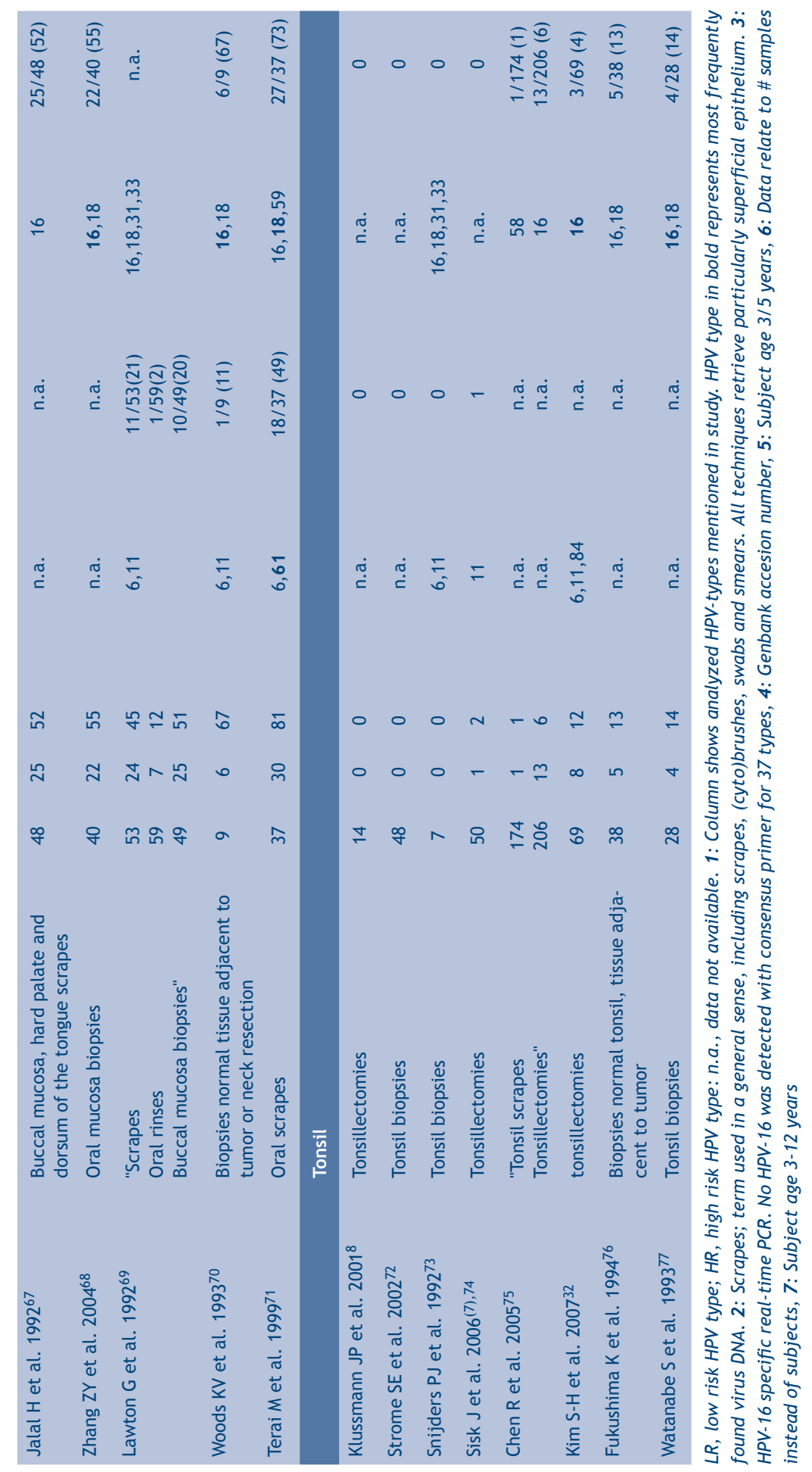


In conclusion, p16 ${ }^{\text {INK4A }}$ expression is regularly observed in tumor-free tonsil tissue but is not associated with HPV, and should therefore be used with caution as a biomarker in normal tissue. Other mechanisms than HPV infection are therefore implicated in upregulation of $\mathrm{p} 16^{\text {INK4A }}$.

\section{Acknowledgments}

The authors thank Ms. Sandra Claessen (Department of Molecular Cell Biology, Maastricht University Medical Center, The Netherlands) for outstanding technical support, and Prof. Dr. Frans C.S. Ramaekers and Dr. Anton H.N. Hopman (Department of Molecular Cell Biology, Maastricht University Medical Center, The Netherlands) for helpful suggestions. 


\section{References}

1. Parkin DM, Pisani P, Ferlay J. Estimates of the worldwide incidence of twenty-five major cancers in 1990. Int J Cancer 1999;80:827-41.

2. Lewin F, Norell SE, Johansson H, Gustavsson P, Wennerberg J, Biorklund A, Rutqvist LE. Smoking tobacco, oral snuff, and alcohol in the aetiology of squamous cell carcinoma of the head and neck. Cancer 1998;82:1367-75.

3. Forastiere A, Koch W, Trotti A, Sidransky D. Head and neck cancer. N Engl J Med 2001;345:1890 -900 .

4. Paz IB, Cook N, Odom-Maryon T, Xie Y, Wilczynski SP. Human papillomavirus (HPV) in head and neck cancer. An association of HPV 16 with squamous cell carcinoma of Waldeyer's tonsillar ring. Cancer 1997;79:595-604.

5. McKaig RG, Baric RS, Olshan AF. Human papillomavirus and head and neck cancer: epidemiology and molecular biology. Head Neck 1998;20:250-65. Review.

6. Gillison ML, Koch WM, Capone RB, Spafford M, Westra WH, Wu L, Zahurak ML, Daniel RW, Viglione $M$, Symer DE, Shah KV, Sidransky D. Evidence for a causal association between human papillomavirus and a subset of head and neck cancers. J Natl Cancer Inst 2000;92:709-20.

7. van Houten VM, Snijders PJ, van den Brekel MW, Kummer JA, Meijer CJ, van Leeuwen B, Denkers F, Smeele LE, Snow GB, Brakenhoff RH. Biological evidence that human papillomaviruses are etiologically involved in a subgroup of head and neck squamous cell carcinomas. Int J Cancer 2001;93:232-5.

8. Klussmann JP, Weissenborn SJ, Wieland U, Dries V, Kolligs J, Jungehuelsing M, Eckel HE, Dienes HP, Pfister HJ, Fuchs PG. Prevalence, distribution, and viral load of human papillomavirus 16 DNA in tonsillar carcinomas. Cancer 2001;92:2875-84.

9. Klussmann JP, Gültekin E, Weissenborn SJ, Wieland U, Dries V, Dienes HP, Eckel HE, Pfister HJ, Fuchs PG. Expression of p16 protein identifies a distinct entity of tonsillar carcinomas associated with human papillomavirus. Am J Pathol 2003;162:747-53.

10. Hafkamp HC, Speel EJ, Haesevoets A, Bot FJ, Dinjens WN, Ramaekers FCS, Hopman AH, Manni JJ. A subset of head and neck squamous cell carcinomas exhibits integration of HPV 16/18 DNA and overexpression of p16INK4A and p53 in the absence of mutations in p53 exons 5-8. Int J Cancer 2003; 107:394-400.

11. Bosch FX, Lorincz A, Munoz N, Meijer CJ, Shah KV. The causal relation between human papillomavirus and cervical cancer. J Clin Pathol 2002;55:244-65.

12. zur Hausen H. Papillomaviruses and cancer: from basic studies to clinical application. Nat Rev Cancer 2002;2:342-50.

13. Bohmer G, van den Brule AJ, Brummer O, Meijer CL, Petry KU. No confirmed case of human papillomavirus DNA-negative cervical intraepithelial neoplasia grade 3 or invasive primary cancer of the uterine cervix among 511 patients. Am J Obstet Gynecol 2003;189:118-20.

14. Frisch M, Biggar RJ. Aetiological parallel between tonsillar and anogenital squamous-cell carcinomas. Lancet 1999;354:1442-3.

15. Mork J, Lie AK, Glattre E, Hallmans G, Jellum E, Koskela P, Moller B, Pukkala E, Schiller JT, Youngman L, Lehtinen $M$, Dillner J. Human papillomavirus infection as a risk factor for squamous-cell carcinoma of the head and neck. N Engl J Med 2001;344:1125-31.

16. Chaturvedi AK, Engels EA, Anderson WF, Gillison ML. Incidence trends for human papillomavirus-related and -unrelated oral squamous cell carcinomas in the United States. J Clin Oncol. 2008;26:612-9.

17. Hafkamp HC, Manni JJ, Speel EJM. Role of human papillomavirus in the development of head and neck squamous cell carcinomas. Acta Otolaryngol 2004;124:520-26.

18. Fakhry C, Gillison ML. Clinical implications of human papillomavirus in head and neck cancers. J Clin Oncol 2006;24:2606-11.

19. Andl T, Kahn T, Pfuhl A, Nicola T, Erber R, Conradt C, Klein W, Helbig M, Dietz A, Weidauer H, Bosch FX. Etiological involvement of oncogenic human papillomavirus in tonsillar squamous cell carcinomas lacking retinoblastoma cell cycle control. Cancer Res 1998;58:5-13 
20. Wiest T, Schwartz E, Enders C, Flechtmacher C, Bosch FX Involvement of intact HPV 16 E6/E7 expression in head and neck cancers with unaltered p53 status and perturbed pRb cell cycle control. Oncogene 2002;21:1510-7.

21. Li W, Thompson CH, Cossart YE, O’Brien CJ, McNeil EB, Scolyer RA, Rose BR. The expression of key cell cycle markers and presence of human papillomavirus in squamous cell carcinoma of the tonsil. Head Neck 2004;26:1-9.

22. Mooren JJ, Manni JJ, Hafkamp HC, Klingenberg B, Voogd AC, Bot FJ, Claessen SMH, Hopman AHN, Ramaekers FCS, Kremer B, Speel EJM. Cell cycle protein expression patterns in HPV-containing and -lacking tonsillar squamous cell carcinomas and association with prognosis: a role for p21? (abstract) Oral Oncol Suppl 2007;2:84.

23. Erber R, Klein W, Andl T, Enders C, Born Al, Conradt C, Bartek J, Bosch FX. Aberrant p21(CIP1/WAF1) protein accumulation in head-and-neck cancer. Int J Cancer 1997;74:383-9.

24. Almadori G, Galli J, Cadoni G, Bussu F, Maurizi M. Human papillomavirus infection and cyclin D1 gene amplification in laryngeal squamous cell carcinoma: biologic function and clinical significance. Head Neck 2002;24:597-604.

25. Mao L, Hong WK, Papadimitrakopoulou VA. Focus on head and neck cancer. Cancer Cell 2004;5:311-6.

26. Reimers N, Kasper HU, Weissenborn SJ, Stützer H, Preuss SF, Hoffmaan TK, Speel EJM, Dienes HP, Pfister HJ, Guntinas-Lichius O, Klussmann JP. Combined analysis of HPV-DNA, p16 and EGFR expression to predict prognosis in oropharyngeal cancer. Int J Cancer 2007;120:1731-8.

27. Begum S, Cao D, Gillison M, Zahurak M, Westra WH. Tissue distribution of human papillomavirus 16 DNA integration in patients with tonsillar carcinoma. Clin Cancer Res 2005;11:5694-9.

28. Hafkamp HC, Manni JJ, Haesevoets A, Voogd AC, Schepers M, Bot FJ, Hopman AH, Rmaekers FCS, Speel EJM. Marked differences in survival rate between smokers and nonsmokers with HPV 16 associated tonsillar carcinomas. Int J Cancer 2008;122:2656-64.

29. Smeets SJ, Hesselink AT, Speel EJ, Haesevoets A, Snijders PJ, Pawlita M, Meijer CJ, Braakhuis BJ, Leemans CR, Brakenhoff RH. A novel algorithm for reliable detection of human papillomavirus in paraffin embedded head and neck cancer specimen. Int J Cancer 2007;121:2465-72.

30. Wilczynski SP, Lin BTY, Xie Y, Paz IB. Detection of human papillomavirus DNA and oncoprotein overexpression are associated with distinct morphological patterns of tonsillar squamous cell carcinoma. Am J Pathol 1998;152:145-56.

31. Francesschi S, Munoz N, Snijders PJF. How strong and how wide is the link between HPV and oropharyngeal cancer? Lancet 2000;356: 871-2.

32. Kim SH, Koo BS, Kang S, Park K, Kim H, Lee KR, Lee MJ, Kim JM, Choi EC, Cho NHI. HPV integration begins in the tonsillar crypt and leads to the alteration of p16, EGFR and c-myc during tumor formation. Int J Cancer 2007;120:1418-25.

33. Herrero R, Castellsague X, Pawlita M, Lissowska J, Kee F, Balaram P, Rajkumer T, Sridhar H, Rose B, Pintos J, Fernandez L, Idris A, Sanchez MJ, Nieto A, Talamini R, Tavani A, Bosch FX, Reidel U, Snijders PJ, Meijer CJ, Viscidi R, Munoz N, Franceschi S; IARC Multicenter Oral Cancer Study Group. Human papillomavirus and oral cancer: the International Agency for Research on Cancer multicenter study. J Natl Cancer Inst 2003;95:1772-83.

34. Klaes R, Friedrich T, Spitkovsky D, Ridder R, Rudy W, Petry U, Dallenbach-Hellweg G, Schmidt D, vond Knebel Doeberitz M. Overexpression of $\mathrm{p} 16^{\mathrm{INK} 4 \mathrm{~A}}$ as a specific marker for dysplastic and neoplastic epithelial cells of the cervix uteri. Int J Cancer 2001;92:276-84.

35. Fregonesi PA, Teresa DB, Duarte RA, Neto CB, de Oliveira MR, Soares CP. p16 ${ }^{\text {INK4A }}$ immunohistochemical overexpression in premalignant and malignant oral lesions infected with human papillomavirus. $J$ Histochem Cytochem 2003;51:1291-7.

36. Bauer HM, Ting Y, Greer CE, Chambers JC, Tashiro CJ, Chimera J, Reingold A, Manos MM. Genital human papillomavirus infection in female university students as determined by a PCR-based method. JAMA 1991;265:472-7.

37. Wieland U, Jurk S, Weissenborn S, Krieg T, Pfister H, Ritzkowsky A. Erythroplasia of Queyrat: coinfection with cutaneous carcinogenic human papillomavirus type 8 and genital papillomaviruses in a carcinoma in situ. J Invest Dermatol 2000;115:396-401. 
38. Jacobs MV, Snijders PJF, van den Brule AJC, Helmerhorst TJM, Meijer CJLM, Walboomers JMM. A general primer GP51/GP61-mediated PCR-enzyme immunoassay method for rapid detection of 14 high-risk and 6 low-risk human papillomavirus genotypes in cervical scrapings. J Clin Microbiol 1997;35:791-5.

39. van den Brule AJ, Pol R, Fransen-Daalmeijer N, Schouls LM, Meijer CJ, Snijders PJ. GP51/61 PCR followed by reverse line blot analysis enables rapid and high-throughput identification of human papillomavirus genotypes. J Clin Microbiol 2002;40:779-87.

40. Heim A, Ebnet C, Harste G, Pring-Akerblom P. Rapid and quantitative detection of human adenovirus DNA by real-time PCR. J Med Virol 2003;70:228-39. Erratum in: J Med Virol 2003;71:320.

41. Hopman AHN, Kamps MAF, Speel EJM, Schapers RFM, Sauter G, Ramaekers FCS. Identification of chromosome 9 alterations and p53 accumulation in isolated carcinoma in situ of the urinary bladder versus carcinoma in situ associated with carcinoma. Am J Pathol 2002;161:1119-25.

42. Hopman AH, Smedts F, Dignef W, et al. Transition of high-grade cervical intraepithelial neoplasia to micro-invasive carcinoma is characterized by integration of HPV 16/18 and numerical chromosome abnormalities. J Pathol 2004;202:23-33.

43. Speel EJM, Ramaekers FCS, Hopman AHN. Sensitive multicolor fluorescence in situ hybridization using catalyzed reporter deposition (CARD) amplification. J Histochem Cytochem 1997;45:1439-46.

44. Hopman AHN, Ramaekers FCS, Speel EJM. Rapid synthesis of biotin-, digoxigenin-, trinitrophenyl-, and fluorochrome-based tyramides and their application for in situ hybridization using CARD amplification. J Histochem Cytochem 1998;46: 771-7.

45. Cooper K, Herrington CS, Stickland JE, Evans MF, McGee JO’D. Episomal and integrated human papillomavirus in cervical neoplasia shown by non-isotopic in situ hybridization. J Clin Pathol 1991;44: 990-6.

46. Poddighe PJ, Bulten J, Kerstens HMJ, Robben JCM, Melchers WJG, Hanselaar AGJM. Human papillomavirus detection by in situ hybridization signal amplification based on biotinylated tyramine deposition. J Clin Pathol Mol Pathol 1996;49:M340-4.

47. Kumar V, Abbas AK, Fausto N Robbins and Cotran pathologic basis of disease, $7^{\text {th }}$ ed. Philadelphia, Elsevier Saunders, 2005.

48. Castillo JP, Kowalik TF. Human cytomegalovirus immediate early proteins and cell growth control. Gene 2002;290:19-34.

49. Helt A-M, Galloway DA. Mechanisms by which DNA tumor virus oncoproteins target Rb family of pocket proteins. Carcinogenesis 2003;24:159-69.

50. Ben-Porath I, Weinberg RA. The signals and pathways activating cellular senescence. Int. J. Biochem. Cell Biol 2005;37:961-76.

51. Kim SH, Kaminker P, Campisi J. Telomeres, aging and cancer: in search of a happy ending. Oncogene 2002;21:503-11.

52. Cánepa ET, Scassa ME, Ceruti JM, Marazita MC, Carcagno AL, Sirkin PF, Ogara MF. INK4 proteins, a family of mammalian CDK inhibitors with novel biological functions. IUBMB Life. 2007;59:419-26.

53. Krishnamurthy J, Torrice C, Ramsey MR, Kovalev GI, Al-Regaiey K, Su L, Sharpless NE. Ink4a/Arf expression is a biomarker of aging. J Clin Invest 2004;114:1299-1307.

54. Bouda M, Gorgoulis VG, Kastrinakis NG, Giannoudis A, Tsoli E, Danassi-Afentaki D, Foukas P, Kyroudi A, Laskaris G, Herrington CS, Kittas C. "High risk" HPV types are frequently detected in potentially malignant and malignant oral lesions, but not in normal oral mucosa. Mod Pathol 2000;13:644-53.

55. Eike A, Buchwald C, Rolighed J, Lindeberg H. Human papillomavirus (HPV) is rarely present in normal oral and nasal mucosa. Clin Otolaryngol 1995;20:171-3.

56. Sand L, Jalouli J, Larsson PA, Hirsch JM. Human papilloma viruses in oral lesions. Anticancer Res 2000;20:1183-8.

57. Ostwald C, Müller P, Barten M, Rutsatz K, Sonnenburg M, Milde-Langosch K, Löning T. Human papillomavirus DNA in oral squamous cell carcinomas and normal mucosa. J Oral Pathol Med 1994;23:220-5.

58. D'Souza G, Kreimer AR, Viscidi R, Pawlita M, Fkhry C, Koch WM, Westra WH, Gillison ML. Case-control study of human papillomavirus and oropharyngeal cancer. N Engl J Med 2007;356:1944-56. 
59. Smith EM, Hoffman HT, Summersgill KS, Kirchner HL, Turek LP, Haugen TH. Human papillomavirus and risk of oral cancer. Laryngoscope 1998;108:1098-103.

60. Summersgill KF, Smith EM, Levy BT, Allen JM, Haugen TH, Turek LP. Human papillomavirus in the oral cavities of children and adolescents. Oral Surg Oral Med Oral Pathol Oral Radiol Endod 2001;91:62-9.

61. Lambropoulos AF, Dimitrakopoulos J, Frangoulides E, Katopodi R, Kotsis A, Karakasis D. Incidence of human papillomavirus 6,11, 16, 18 and 33 in normal oral mucosa of a Greek population. Eur J Oral Sci 1997;105:294-7.

62. Jimenez C, Correnti M, Salma N, Cavazza ME, Perrone M. Detection of human papillomavirus DNA in benign oral squamous epithelial lesions in Venezuela. J Oral Pathol Med. 2001;30:385-8.

63. Holladay EB, Gerald WL Viral gene detection in oral neoplasms using the polymerase chain reaction. Am J Clin Pathol 1993;100:36-40.

64. Sugiyama M, Bhawal UK, Dohmen T, Ono S, Miyauchi M, Ishikawa T. Detection of human papillomavirus16 and HPV-18 DNA in normal, dysplastic, and malignant oral epithelium. Oral Surg Oral Med Oral Pathol Oral Radiol Endod 2003;95:594-600.

65. Kojima A, Maeda H, Kurahashi N, Sakagami G, Kubo K, Yoshimoto H, Kameyama Y. Human papillomaviruses in the normal oral cavity of children in Japan. Oral Oncol 2003;39:821-8.

66. Adams V, Schmid S, Zariwala M, Schmid M, Kleihues P, Briner J, Schäfer R. Prevalence of human papilloma virus DNA in head and neck cancers carrying wild-type or mutant p53 tumor suppressor genes. Anticancer Res 1999;19:1-6.

67. Jalal H, Sanders CM, Prime SS, Scully C, Maitland NJ. Detection of human papilloma virus type 16 DNA in oral squames from normal young adults. J Oral Pathol Med 1992;21:465-70.

68. Zhang Z-y, Sdek P, Cao J, Chen W-t. Human papillomavirus type 16 and 18 DNA in oral squamous cell carcinoma and normal mucosa. Int J Oral Maxillofac Surg 2004;33: 71-4.

69. Lawton G, Thomas S, Schonrock J, Monsour F, Frazer I. Human papillomaviruses in normal oral mucosa: a comparison of methods for sample collection, J Oral Pathol Med 1992;21: 265-9.

70. Woods KV, Shillitoe EJ, Spitz MR, Schantz SP, Adler-Storthz K. Analysis of human papillomavirus DNA in oral squamous cell carcinomas. J Oral Pathol Med 1993;22:101-8.

71. Terai M, Hashimoto K, Yoda K, Sata T. High prevalence of human papillomaviruses in the normal oral cavity of adults. Oral Microbiol Immunol 1999;14:201-5.

72. Strome SE, Savva A, Brissett AE, Gostout BS, Lewis j, Clayton AC, McGovern R, Weaver AL, Persing D, Kasperbauer JL. Squamous cell carcinoma of the tonsils: a molecular analysis of HPV associations. Clin Cancer Res 2002;8:1093-100.

73. Snijders PJ, Cromme FV, van den Brule AJ, Schrijnemakers HF, Snow GB, Meijer CJ, Walboomers JM. Prevalence and expression of human papillomavirus in tonsillar carcinomas, indicating a possible viral etiology. Int J Cancer 1992;51:845-50.

74. Sisk J, Schweinfurth JM, Wang XT, Chong K. Presence of human papillomavirus DNA in tonsillectomy specimens. Laryngoscope 2006;116:1372-4.

75. Chen R, Sehr P, Waterboer T, Leivo I, Pawlita M, Vaheri A, Aaltonen LM. Presence of DNA of human papillomavirus 16 but no other types in tumor-free tonsillar tissue. J Clin Microbiol 2005;43:140810.

76. Fukushima K, Ogura H, Watanabe S, Yabe Y, Masuda Y. Human papillomavirus type 16 DNA detected by the polymerase chain reaction in non-cancer tissues of the head and neck. Eur Arch Otorhinolaryngol 1994;251:109-12.

77. Watanabe S, Ogura H, Fukushima K, Yabe Y. Comparison of Virapap filter hybridization with polymerase chain reaction and Southern blot hybridization methods for detection of human papillomavirus in tonsillar and pharyngeal cancers. Eur Arch Otorhinolaryngol 1993;250:115-9. 


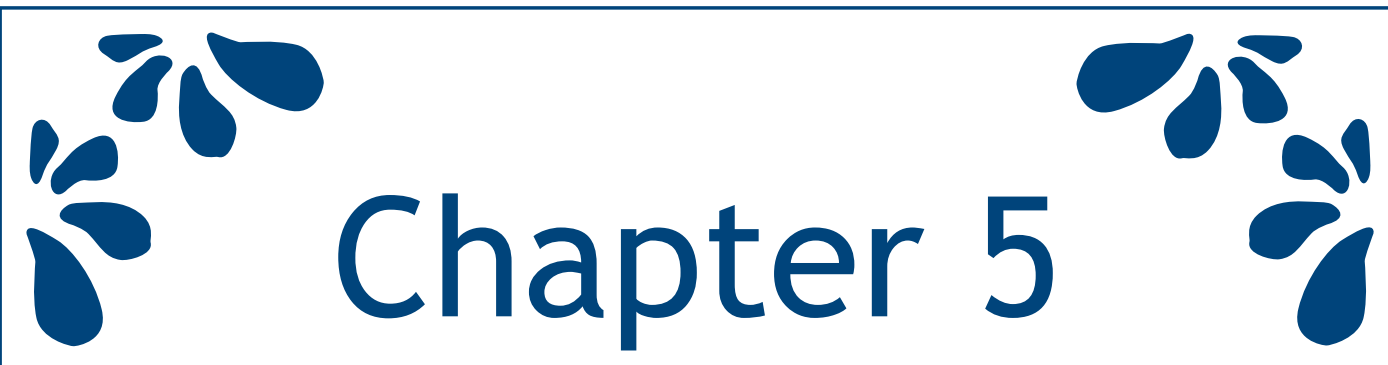

P21 Cip1/WAF1 expression is strongly associated with HPV-positive tonsillar carcinoma and a favorable prognosis

Harriët C. Hafkamp, Jeroen J. Mooren, Sandra M.H. Claessen, Boris Klingenberg, Adri C. Voogd, Fredrik J. Bot, J. Peter Klussmann, Anton H.N. Hopman, Johannes J. Manni, Bernd Kremer, Frans C.S. Ramaekers, and Ernst-Jan M. Speel 


\begin{abstract}
Human papillomavirus (HPV) is involved in the carcinogenesis of tonsillar squamous cell carcinomas (TSCC). In this study we investigated the expression and prognostic value of key cell cycle proteins in the retinoblastoma (pRb) and p53 pathways in both HPV16-positive and -negative TSCC. Using immunohistochemistry 77 TSCC with known HPV16 status and clinical outcome were analyzed for expression of Ki67, p16 ${ }^{\text {INK4A }}$, cyclin D1, pRb, p14ARF, MDM2, p53, p21 Cip1/WAF1, and p27 KIP1. Results were correlated with each other and with clinical and demographic patient data. Survival from TSCC was determined by Kaplan Meier and Cox proportional hazard regression analysis. Nearly all (97\%) TSCC showed a high proliferation index as concluded from a nuclear Ki67 expression in 30-90\% of the tumor cells. Approximately one-third of these (35\%) TSCC harbored HPV16 DNA integrated in the host genome, and showed p16 INK4A overexpression, both being considered essential features for HPV association. These TSCC also showed overexpression of p14ARF $(p<0.0001)$ and p21 Cip1/WAF1 $(p=0.001)$, and downregulation of $\mathrm{pRb}(\mathrm{p}<0.0001)$ and cyclin $\mathrm{D} 1(\mathrm{p}=0.027)$ as compared to the HPV-negative cases. Univariate Cox regression analyses revealed a high survival rate for non-smokers $(p=0.006)$, as well as for patients with TSCC classified as T1-2 $(p<0.0001)$. Also low expression of cyclin D1 $(p=0.028)$, presence of HPV and overexpression of $p 16^{\text {INK4A }}(p=0.01), p 14^{\text {ARF }}(p=0.02)$ or $p 21^{\text {Cip } 1 / \text { WAF1 }}(p=0.004)$ were correlated with survival in a favorable manner. In multivariate Cox regression analyses smoking and tumor size, as well as expression of cyclin D1 and p21 Cip1/ WAF1 were found to be independent prognostic markers. We conclude that HPVpositivity in TSCC strongly correlates with p21 Cip1/WAF1 and p14ARF overexpression and downregulation of pRb and cyclin D1. In particular p21 Cip1/WAF1 overexpression is an excellent favorable prognosticator in TSCC.
\end{abstract}




\section{Introduction}

Head and neck squamous cell carcinoma (HNSCC) is the sixth most prevalent malignancy in the world, contributing $6 \%$ of new cancer cases annually worldwide ${ }^{1,2}$. HNSCC has a 5 -year survival rate of approximately $50 \%$, which has not improved in the last 2 decades ${ }^{3}$. Well recognized risk factors in the etiology of HNSCC are extensive tobacco smoking and alcohol consumption in $-90 \%$ of cases, as well as oncogenic human papillomaviruses (HPVs), predominantly HPV type 163,4. Interestingly, the association of HPV is strongest for tonsillar carcinoma (TSCC) with a prevalence up to $50 \% 5-8$. The diagnosis of HPV-positivity in HNSCC appears to have significant prognostic implications. In one study these patients had a less than $50 \%$ chance of dying from the disease as compared to HPV negative tumors?.

It has been shown that there are several differences between HPV-positive and -negative HNSCC. Despite the fact that HPV-positivity in HNSCC is an indicator for favorable prognosis, from a clinical point of view these tumors are often poorly differentiated $\mathrm{d}^{4,6,10-12}$ and metastasized to lymph nodes at presentation ${ }^{10,11}$. Furthermore, HPV-positive tumors are often smaller at first diagnosis (diameter $\leq$ $4 \mathrm{~cm})^{13}$, and associated with low/no exposure to alcohol and tobacco smoke ${ }^{10,11}$. At the molecular level the functional inactivation of two key tumor suppressor proteins, i.e. p53 and pRb by the HPV-derived oncoproteins E6 and E7, often result in downregulation of p53, pRb, cyclin D1 and a strong up-regulation of $\mathrm{p} 16^{1 \mathrm{NK} 4 \mathrm{~A}}$ in HPVpositive tumors $5,7,14-16$. HPV-negative tumors, in contrast, often show inactivation of p16 ${ }^{\text {INK4A }}$, p53 overexpression as a result of gene mutations, cyclin D1 gene amplification and overexpression, as well as EGFR accumulation ${ }^{3,17-19}$.

The literature, however, shows conflicting data with respect to HPV-associated characteristics and clinical outcome of HNSCC. First, although many studies describe a significant association between HPV-presence and favorable prognosis, some studies did not find such a correlation ${ }^{20-22}$. Second, HPV has also been identified in HNSCC of smokers, significantly reducing its favorable effect on clinical outcome ${ }^{13}$. Furthermore, despite the fact that regional lymph node metastasis is considered the most important prognostic factor in $\mathrm{HNSCC}^{23}$, this parameter seems to be unreliable in $\mathrm{TSCC}^{24,25}$. Finally, some studies reported overexpression and/or p53 mutations almost exclusively in HPV-negative tumors ${ }^{20}$, while others have found that HPV-infection and $p 53$ alterations can coexist ${ }^{26}$. This may have a strong effect on survival, because it has been indicated that tumors with intact p53 are still capable 
of inducing apoptosis in response to radiation therapy, which results in a favorable clinical outcome ${ }^{27}$.

This study was undertaken to investigate the expression of key cell cycle proteins in the pRb pathway (p16 INK4A , cyclin D1, p2 $\left.7^{\mathrm{Kip} 1}, \mathrm{pRb}\right)$ and the p53 cascade (P14 ARF, MDM2, p53 and p21 Cip1/WAF1 $)$, using a series of 77 TSCC for which the HPV16 status and the clinical follow-up data were available. TSCC show the highest prevalence of oncogenic HPV and are thus ideally suited to search for molecular and clinicopathological differences induced by either HPV, or tobacco smoking and alcohol consumption.

\section{Materials and Methods}

\section{Tumor material and patient data}

Formaldehyde fixed, paraffin embedded archival biopsy and resection material of primary TSCC from 77 patients, which had been previously examined for HPV16 association ${ }^{13}$, was selected from the archives of the Department of Pathology, University Hospital Maastricht, The Netherlands. Demographic data, including age at diagnosis, gender, alcohol and tobacco smoke exposure, treatment modality and date and cause of death were obtained from the medical records. Tumor site, degree of differentiation (i.e., well, moderately, or poorly differentiated) and TNM classification were determined from review of pathological, radiological and surgical reports. All patients were treated by surgery, radiotherapy, chemotherapy or a combination, irrespective of HPV status. The study protocol was approved by the institutional ethical committee, and all patients gave informed consent. Table 1 provides demographic and clinical features of the 77 patients included in this study. Fifty-seven patients were male and 20 patients were female. The mean age at diagnosis was 58.8 (range 39-87) years. Data concerning smoking and alcohol intake were obtained from 76 and 75 patients, respectively. Sixty-four (84\%) of 76 patients were smokers ( $\geq 1$ cigarette, pipe, and/or cigar per day) and $46(61 \%)$ of 75 patients were classified as drinkers (consumption of $>2$ whiskey equivalents per day ( 1 whiskey equivalent $\sim 10 \mathrm{~g}$ alcohol)). Forty-two (55\%) of the patients used both tobacco and alcohol, while only $8(10 \%)$ patients had not been subjected to these intoxications. Thirty-nine (51\%) patients had a tumor with a diameter $\geq 4 \mathrm{~cm}$, and $55(71 \%)$ had lymph node metastasis at time of diagnosis. Tumor grade was poor or 
moderate in $63(82 \%)$ patients, well differentiated in $10(13 \%)$ patients, unavailable in 3 patients (4\%), and 1 patient (1\%) had a carcinoma in situ. Following primary treatment, 29 (38\%) of the patients never became disease-free, 16 (21\%) developed a recurrent disease (locoregional, regional or distant) and 32 (42\%) patients remained disease-free after primary treatment.

A series of $4 \mu \mathrm{m}$-thick sections was cut from the specimens for hematoxylineosin staining and detailed histopathological classification (F.J.B.), according to the criteria of the World Health Organization ${ }^{28}$. Furthermore, we applied immunohistochemistry to visualize Ki67, p16 INK4A, cyclin D1, pRb, P14ARF, MDM2, p53, p21 $1^{\text {Cip } 1 / \text { WAF1 } 1}$ and p27 ${ }^{\text {Kip } 1}$ expression.

\section{Immunohistochemical staining}

Immunohistochemical protein staining on $4 \mu \mathrm{m}$-thick formaldehyde fixed, paraffin embedded tissue sections was performed as described earlier ${ }^{15}$. Briefly, sections were deparaffinized and subsequently pretreated with $2 \% \mathrm{H}_{2} \mathrm{O}_{2}$ in methanol for 30 minutes to quench endogenous peroxidase activity. Antigen retrieval was performed by microwave heating in $0.01 \mathrm{M}$ citrate buffer $(\mathrm{pH} \mathrm{6.0)}$. The primary antibodies used to detect Ki67, p16 INK4A , cyclin D1, pRb, p14ARF, MDM2, p53, p21 Cip1/WAF1 and p27 $7^{\text {Kip } 1}$ are listed in Table 2 . After incubation with a biotinylated secondary antibody, immunohistochemical detection was performed by an avidin-biotinylated peroxidase complex $(A B C)$ procedure (Vectastain-Elite-ABC kit; Vector). Peroxidase activity was detected using $0.5 \mathrm{mg} / \mathrm{ml}$ diaminobenzidine/ $2 \% \mathrm{H}_{2} \mathrm{O}_{2}$. Sections were counterstained with hematoxylin and mounted in Entellan (Merck, Darmstadt, Germany). In each analysis negative and positive controls were included. Analysis was performed by three independent observers (J.J.M., E.J.M.S. and S.M.H.C.) and in case of interobserver variations, consensus was reached by combined examination of the slides. Both staining intensity $(-,+/-,+,++,+++)$ and the percentage of stained tumor cells were scored. Evaluation criteria for positive scoring of each of the cell cycle proteins are listed in Table 2.

\section{Statistical analysis}

The study population consisted of 77 patients with a TSCC diagnosed between 1992 and 2001. TSCC were considered to be HPV-associated if they showed HPV16 presence by in situ hybridization analysis, and in addition overexpression of p16 ${ }^{\text {INK4A }}$ 
as detected by immunohistochemistry. Factors associated with HPV status were selected on cross-tabulations, which were analyzed by the use of the two-tailed Fisher exact test and/or Chi-square test. The maximum significance levels are indicated for all analyses $(p \leq 0.05)$. Disease-specific survival curves were calculated using the Kaplan-Meier method. Survival was calculated from the date of diagnosis until patient's death or until the last date the patient was known to be alive (this ranged from 16-141 months). Patients that died of other causes than tonsillar carcinoma were considered censored observations in the disease-specific survival analyses. Disease-free survival was calculated from the date of diagnosis until the date of recurrence (local, regional or distant, whichever occurred first). Patients without recurrence were censored at the date of the last follow-up or the date of death. The statistical significance of differences between survival times was determined by the log rank test in univariate analysis. Multivariate analyses were performed using the Cox proportional hazards model. Variables in the multivariate model included: HPVassociation, T-classification, smoking, cyclin D1-, p14ARF - and p21 Cip1/WAF1 expression. Variables remained in the model if their $p$-values were below 0.10 . All calculations were performed by use of the SPSS Base System version 12.0.1.

\section{Results}

\section{Cell cycle protein expression}

Seventy-seven TSCC were examined for expression of the cell cycle proteins Ki67, p16 ${ }^{\text {INK4A }}$, Cyclin D1, pRb, P14ARF, MDM2, p53, p2 $1^{\text {Cip1/WAF1 }}$ and p27 ${ }^{\text {Kip } 1}$ using the primary antibodies and evaluation criteria stated in Table 2. Representative immunostaining results in normal epithelium and tumor tissues are shown in Figure 1. The frequency of tumors exhibiting expression of the respective proteins is presented in Figure 2A. Seventy-five out of 77 (97\%) TSCC showed strong, nuclear Ki67 expression in 30-90\% of the tumor cells (Figure 1A). Also nuclear pRb staining was often observed in TSCC (62 out of 77 cases, $81 \%$ ), although two subsets were identified with a difference in staining intensity (i.e., tumors showing $<$ or $\geq$ intense immunostaining than present in the adjacent squamous epithelium. Figure $1 \mathrm{D}$ versus $1 \mathrm{~J}$, respectively). A significant association was seen between overexpression of pRb (a higher nuclear staining intensity in tumor cells than in the adjacent normal squamous epithelium) and $p 53$ accumulation $(p=0.017)$. Both overexpression of $p 53$ and $p 21^{\text {Cip } 1 / \text { WAF } 1}$ 
correlated independently with accumulation of MDM2 (Figure 1K) $(p=0.030$ and $p$ $=0.004$, respectively), but not with each other (data not shown). In addition, there was a significant association between overexpression of $\mathrm{p} 16^{\mathrm{INK} 4 \mathrm{~A}}$ and overexpression of both $\mathrm{p} 14^{\mathrm{ARF}}(\mathrm{p}<0.0001)$ and $\mathrm{p} 21^{\text {Cip1/WAF1 }}(\mathrm{p}=0.027$ ) (Figure $1 \mathrm{~B}, \mathrm{C}$ and $\mathrm{F})$. In case of $\mathrm{p} 14^{\mathrm{ARF}}$ overexpression in the tumor, a diffuse nuclear staining pattern was more often observed than nucleolar staining (Figure 1C, above versus below, respectively). Furthermore, $\mathrm{p} 16^{1 \mathrm{NK} 4 \mathrm{~A}}$ accumulation strongly correlated with both downregulation of pRb ( $<$ 0.0001) and cyclin D1 ( $=0.035)$ (Figure 1D and E).

Staining of normal tonsillar squamous epithelium was seen in the basal or parabasal cell layers for Ki67, cyclin D1, pRb, p21 Cip1/WAF1 and p53, varying from low to high intensities (Figure 1A, B, D-G). This squamous epithelium, present in the individual sections, was used as an internal positive control. In p14ARF - and p27 $7^{\text {Kip1 }}$ stained sections, adjacent lymphocyte infiltration often showed a strong cytoplasmatic and nuclear staining, respectively, and therefore served as the internal positive control (Figure $1 \mathrm{~L}$ ).

\section{Correlations between HPV status, expression of cell cycle proteins and} clinicopathological variables

The correlations between each cell cycle marker and HPV status are shown in Table 1 and Figure $2 \mathrm{~b}$. HPV-associated TSCC showed significantly more often overexpression of $\mathrm{p} 14^{\mathrm{ARF}}(\mathrm{p}<0.0001)$ and $\mathrm{p} 21^{\mathrm{Cip} 1 / \text { WAF1 }}(\mathrm{p}=0.008)$, and downregulation of $\mathrm{pRb}$ ( $\mathrm{p}$ $<0.0001)$ and cyclin D1 ( $p=0.027)$ than HPV-negative tumors. P53 accumulation tended to be associated with absence of HPV $(p=0.079)$.

The male/female ratio and the age distribution were similar for the HPVpositive and HPV-negative subgroups. Smoking and alcohol abuse were seen significantly more often in the HPV-negative patient group $(p<0.0001$ and $p=0.024$, respectively). HPV-positive tumors tended to be smaller than HPV-negative tumors $(p=0.065)$. Male patients were more often diagnosed with a T3-4 tumor $(p=0.006)$ and were more often smokers $(p=0.011)$. 
TABLE 1. CLINICOPATHOLOGICAL FEATURES AND CELL CYCLE PROTEIN EXPRESSION IN RELATION TO HPV STATUS

\begin{tabular}{|c|c|c|c|c|}
\hline Characteristic & $\begin{array}{l}\text { All TSCC } \\
n=77 \text { (\%) }\end{array}$ & $\begin{array}{c}\text { HPV-positive } \\
\text { TSCC } \\
n=27(35 \%)\end{array}$ & $\begin{array}{c}\text { HPV-negative } \\
\text { TSCC } \\
n=50(65 \%)\end{array}$ & $\begin{array}{c}\text { Fisher exact } \\
\text { P-value }\end{array}$ \\
\hline \multicolumn{5}{|c|}{ Cell cycle proteins } \\
\hline \multicolumn{5}{|l|}{ Ki67 } \\
\hline Positive & $75(97 \%)$ & $26(96 \%)$ & $49(98 \%)$ & NS \\
\hline Negative & $2(3 \%)$ & $1(4 \%)$ & $1(2 \%)$ & \\
\hline \multicolumn{5}{|l|}{$\mathrm{p} 16^{I N K 4 A}$} \\
\hline Positive & $29(38 \%)$ & $27(100 \%)$ & $2(4 \%)$ & $<0.0001$ \\
\hline Negative & $48(62 \%)$ & $0(0 \%)$ & $48(96 \%)$ & \\
\hline \multicolumn{5}{|l|}{ cyclin D1 > 5\% } \\
\hline Positive & $33(43 \%)$ & $7(26 \%)$ & $26(52 \%)$ & 0.027 \\
\hline Negative & $44(57 \%)$ & $20(74 \%)$ & $24(48 \%)$ & \\
\hline \multicolumn{5}{|l|}{ cyclin D1 > 50\% } \\
\hline Positive & $12(16 \%)$ & $2(7 \%)$ & $10(20 \%)$ & NS \\
\hline Negative & $65(84 \%)$ & $25(93 \%)$ & $40(80 \%)$ & \\
\hline \multicolumn{5}{|l|}{$\mathrm{pRb}>20 \%$} \\
\hline Positive & $62(81 \%)$ & $22(81 \%)$ & $4080 \%)$ & NS \\
\hline Negative & $15(20 \%)$ & $5(19 \%)$ & $10(20 \%)$ & \\
\hline \multicolumn{5}{|c|}{ pRb intensity in tumor $\geq$ intensity } \\
\hline \multicolumn{5}{|c|}{ in adjacent squamous epithelium } \\
\hline Positive & $41(53 \%)$ & $4(15 \%)$ & $37(74 \%)$ & $<0.0001$ \\
\hline Negative & $36(47 \%)$ & $23(85 \%)$ & $13(26 \%)$ & \\
\hline \multicolumn{5}{|l|}{$\mathrm{p} 14^{A R F}$} \\
\hline Positive & $34(44 \%)$ & $20(26 \%)$ & $14(18 \%)$ & $<0.0001$ \\
\hline Negative & $43(56 \%)$ & $7(9 \%)$ & $36(47 \%)$ & \\
\hline \multicolumn{5}{|l|}{ MDM2 } \\
\hline Positive & $23(30 \%)$ & $10(37 \%)$ & $13(26 \%)$ & NS \\
\hline Negative & $54(70 \%)$ & $17(63 \%)$ & $37(74 \%)$ & \\
\hline \multicolumn{5}{|l|}{ p53 } \\
\hline Positive & $39(51 \%)$ & $10(37 \%)$ & $29(58 \%)$ & NS \\
\hline Negative & $38(49 \%)$ & $17(63 \%)$ & $21(42 \%)$ & \\
\hline \multicolumn{5}{|l|}{ p21 Cip1/WAF1 } \\
\hline Positive & $32(42 \%)$ & $17(63 \%)$ & $15(30 \%)$ & 0.008 \\
\hline Negative & $43(56 \%)$ & $10(37 \%)$ & $33(66 \%)$ & \\
\hline Unknown & $2(3 \%)$ & & $2(4 \%)$ & \\
\hline \multicolumn{5}{|l|}{$\mathrm{p} 27^{\mathrm{KIP} 1}$} \\
\hline Positive & $25(33 \%)$ & $9(33 \%)$ & $16(32 \%)$ & NS \\
\hline Negative & $49(64 \%)$ & $18(66 \%)$ & $31(62 \%)$ & \\
\hline Unknown & $3(4 \%)$ & & $3(6 \%)$ & \\
\hline \multicolumn{5}{|c|}{ Clinicopathological variables } \\
\hline \multicolumn{5}{|l|}{ Gender } \\
\hline Female & $20(26 \%)$ & $9(33 \%)$ & $11(22 \%)$ & NS \\
\hline Male & $57(74 \%)$ & $18(67 \%)$ & $39(78 \%)$ & \\
\hline \multicolumn{5}{|l|}{ Age (years) } \\
\hline$<60$ & $41(53 \%)$ & $13(48 \%)$ & $28(56 \%)$ & NS \\
\hline$\geq 60$ & $36(47 \%)$ & $14(52 \%)$ & $22(44 \%)$ & \\
\hline
\end{tabular}




\begin{tabular}{|c|c|c|c|c|}
\hline Characteristic & $\begin{array}{l}\text { All TSCC } \\
n=77(\%)\end{array}$ & $\begin{array}{c}\text { HPV-positive } \\
\text { TSCC } \\
n=27(35 \%)\end{array}$ & $\begin{array}{c}\text { HPV-negative } \\
\text { TSCC } \\
n=50(65 \%)\end{array}$ & $\begin{array}{c}\text { Fisher exact } \\
\text { P-value }\end{array}$ \\
\hline \multicolumn{5}{|l|}{ Death due to TSCC } \\
\hline Yes & $41(53 \%)$ & $8(30 \%)$ & $33(66 \%)$ & 0.002 \\
\hline No & $33(43 \%)$ & $18(67 \%)$ & $15(30 \%)$ & \\
\hline Unknown & $3(4 \%)$ & $1(4 \%)$ & $2(4 \%)$ & \\
\hline \multicolumn{5}{|l|}{ Death due to any cause } \\
\hline Yes & $48(62 \%)$ & $10(37 \%)$ & $38(76 \%)$ & $<0.0001$ \\
\hline No & $26(34 \%)$ & $16(59 \%)$ & $10(20 \%)$ & \\
\hline Unknown & $3(4 \%)$ & $1(4 \%)$ & $2(4 \%)$ & \\
\hline \multicolumn{5}{|l|}{ Smoking ${ }^{1}$} \\
\hline Yes & $64(83 \%)$ & $17(63 \%)$ & $47(94 \%)$ & $<0.0001$ \\
\hline No & $12(16 \%)$ & $10(37 \%)$ & $2(4 \%)$ & \\
\hline Unknown & $1(1 \%)$ & & $1(2 \%)$ & \\
\hline \multicolumn{5}{|l|}{ Alcohol $^{2}$} \\
\hline Yes & $46(60 \%)$ & $12(44 \%)$ & $34(68 \%)$ & 0.024 \\
\hline No & $29(38 \%)$ & $15(56 \%)$ & $14(28 \%)$ & \\
\hline Unknown & $2(3 \%)$ & & $2(4 \%)$ & \\
\hline \multicolumn{5}{|l|}{ Smoking and/or alcohol } \\
\hline Yes & $68(88 \%)$ & $20(74 \%)$ & $48(96 \%)$ & 0.002 \\
\hline No & $8(10 \%)$ & $7(26 \%)$ & $1(2 \%)$ & \\
\hline Unknown & $1(1 \%)$ & & $1(2 \%)$ & \\
\hline \multicolumn{5}{|l|}{ Smoking and alcohol } \\
\hline Yes & $42(55 \%)$ & $9(33 \%)$ & $33(66 \%)$ & 0.003 \\
\hline No & $33(43 \%)$ & $18(67 \%)$ & $15(30 \%)$ & \\
\hline Unknown & $2(3 \%)$ & & $2(4 \%)$ & \\
\hline \multicolumn{5}{|l|}{ TNM-classification } \\
\hline Stage $0-3$ & $39(51 \%)$ & $13(48 \%)$ & $26(52 \%)$ & NS \\
\hline Stage 4 & $37(48 \%)$ & $14(52 \%)$ & $23(46 \%)$ & \\
\hline Unknown & $1(1 \%)$ & & $1(2 \%)$ & \\
\hline \multicolumn{5}{|l|}{ T-classification } \\
\hline$<4 \mathrm{~cm}(\mathrm{~T} 1-2)$ & $37(48 \%)$ & $17(63 \%)$ & $20(40 \%)$ & NS \\
\hline$\geq 4 \mathrm{~cm}(\mathrm{~T} \mathrm{3} 3-4)$ & $39(51 \%)$ & $10(37 \%)$ & $29(58 \%)$ & \\
\hline Unknown & $1(1 \%)$ & & $1(2 \%)$ & \\
\hline \multicolumn{5}{|l|}{ Tumor grade ${ }^{3}$} \\
\hline Poor/ moderate & $63(82 \%)$ & $24(89 \%)$ & $39(78 \%)$ & NS \\
\hline Well & $10(13 \%)$ & $2(7 \%)$ & $8(16 \%)$ & \\
\hline Unknown & $4(5 \%)$ & $1(4 \%)$ & $3(6 \%)$ & \\
\hline \multicolumn{5}{|l|}{ Lymph node metastasis } \\
\hline Positive & $55(71 \%)$ & $22(81 \%)$ & $33(66 \%)$ & NS \\
\hline Negative & $21(27 \%)$ & $5(19 \%)$ & $16(32 \%)$ & \\
\hline Unknown & $1(1 \%)$ & & $1(2 \%)$ & \\
\hline \multicolumn{5}{|l|}{ Recurrent disease } \\
\hline Yes & $16(21 \%)$ & $4(15 \%)$ & $12(24 \%)$ & NS \\
\hline No & $32(42 \%)$ & $16(59 \%)$ & $16(32 \%)$ & \\
\hline Never disease free & $29(38 \%)$ & $7(26 \%)$ & $22(44 \%)$ & \\
\hline
\end{tabular}

$T S C C=$ tonsillar squamous cell carcinoma; HPV = human papillomavrus; NS = not significant. ${ }^{1}$ Patiens were classified as daily tobacco smokers ( $\geq 1$ cigarette, pipe, and/or cigar per day). Or non-smokers (never smokers or patients who had stopped smoking more than 10 years before the diagnosis of TSCC). ${ }^{2}$ Patients were classified as drinkers (consumption of $>2$ whiskey equivalents per day ( 1 whiskey equivalent $\sim 10 \mathrm{~g}$ alcohol). ${ }^{3}$ Tumor grade was scored as well-, moderately-, or poorly differentiated according to the criteria of the World Health Organization 


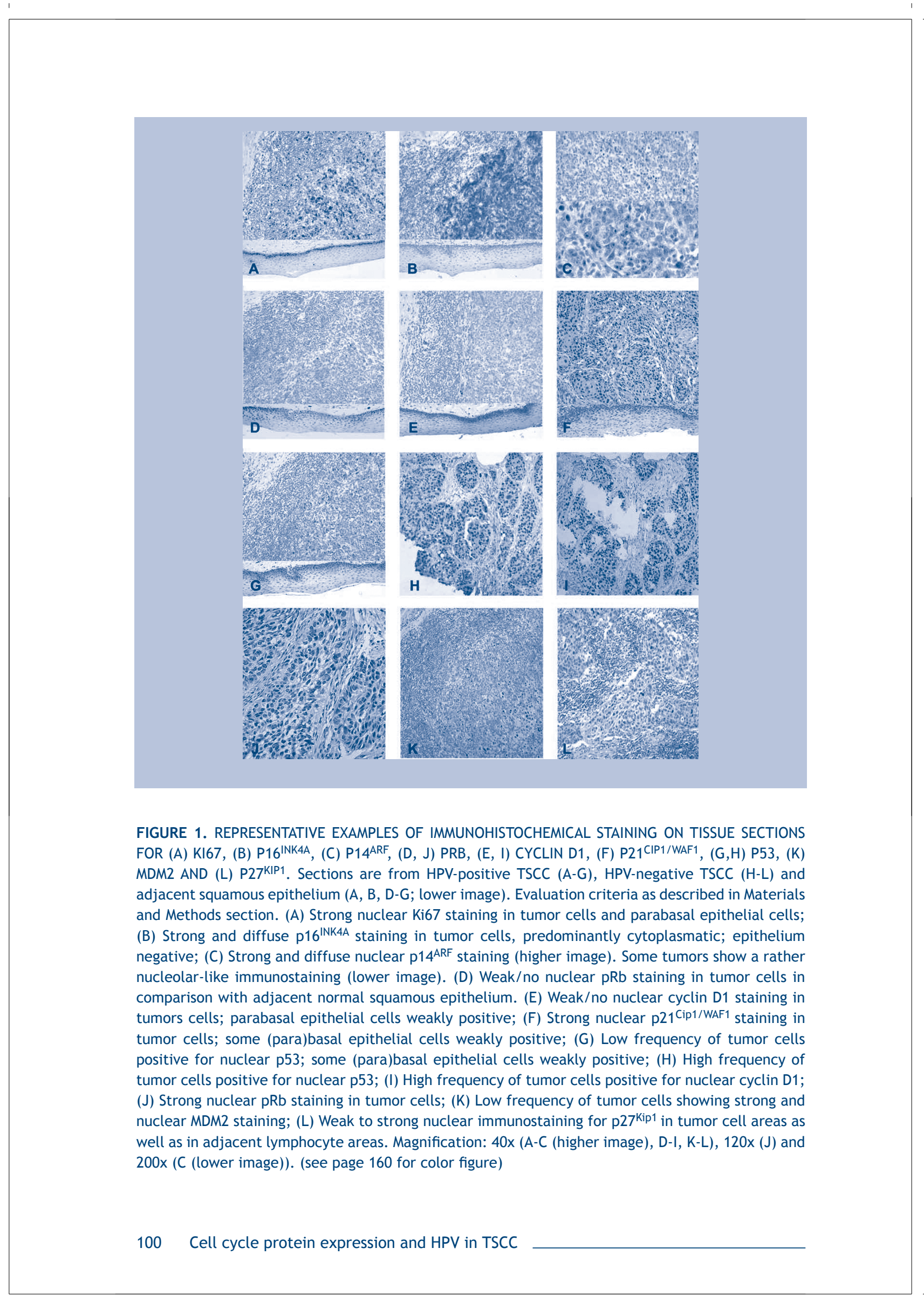




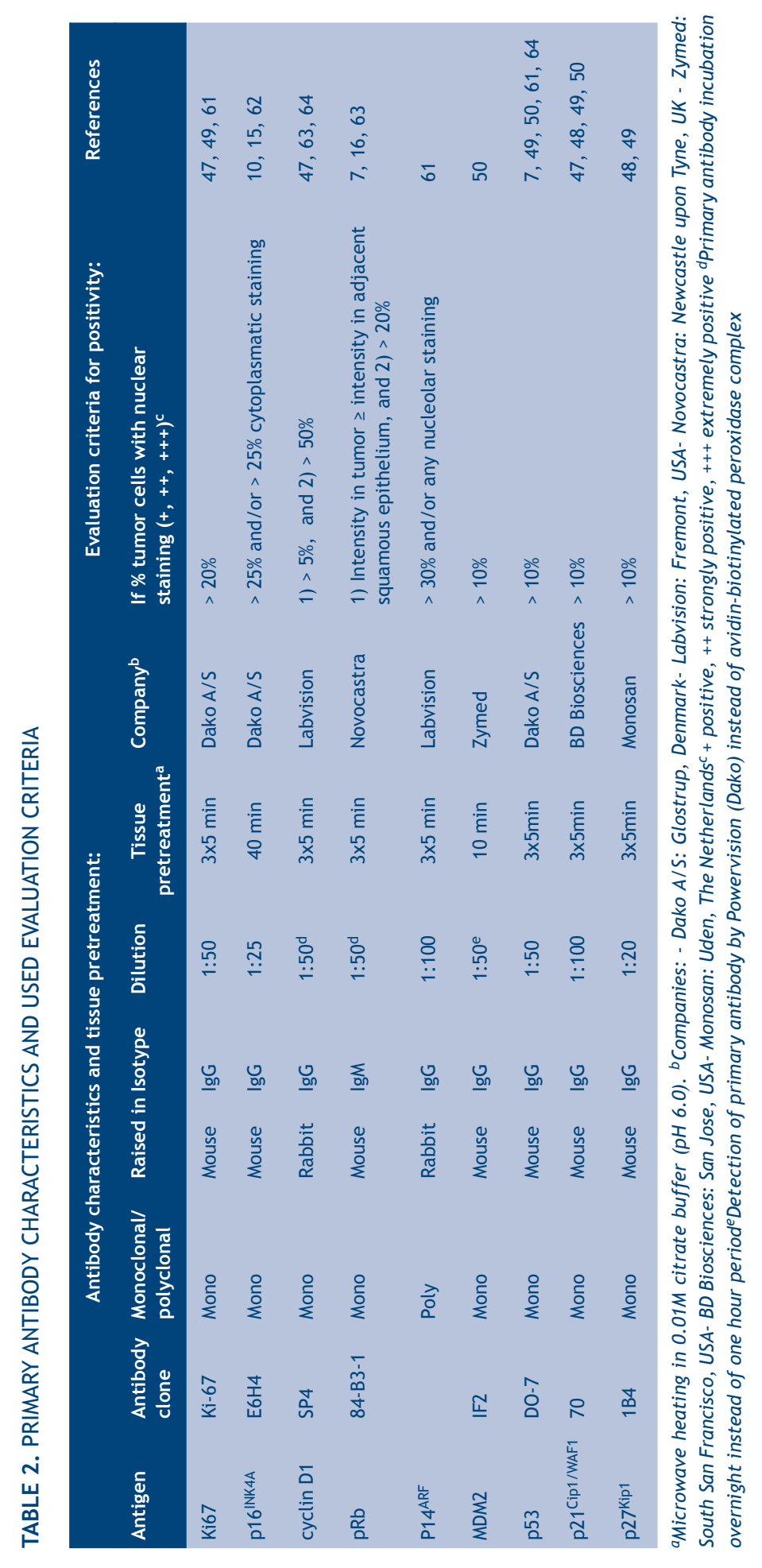


TABLE 3. INFLUENCE OF HPV-RELATED AND CLINICOPATHOLOGIC PARAMETERS ON DISEASE-SPECIFIC SURVIVAL IN 74 PATIENTS WITH TSCC, AS DETERMINED BY UNIVARIATE COX PROPORTIONAL HAZARD REGRESSION ANALYSIS

\begin{tabular}{|c|c|c|c|c|}
\hline Variable & Total & Death & P value ${ }^{1}$ & Unadjusted HR (95\% Cl) \\
\hline \multicolumn{5}{|c|}{ Cell cycle proteins } \\
\hline \multicolumn{5}{|l|}{ Ki67 } \\
\hline Positive & 72 & $40(56 \%)$ & NS & $1.5(0.2-10.9)$ \\
\hline Negative & 2 & $1(50 \%)$ & & 1 (referent) \\
\hline \multicolumn{5}{|l|}{$\mathrm{p} 16^{\text {INK4A }}$} \\
\hline Positive & 28 & $10(36 \%)$ & 0.029 & $0.5(0.2-0.9)$ \\
\hline Negative & 46 & $31(67 \%)$ & & 1 (referent) \\
\hline \multicolumn{5}{|c|}{ cyclin D1 > 5\% } \\
\hline Positive & 31 & $20(65 \%)$ & 0.060 & $1.8(1.0-3.4)$ \\
\hline Negative & 43 & $21(49 \%)$ & & 1 (referent) \\
\hline \multicolumn{5}{|c|}{ cyclin D1 > 50\% } \\
\hline Positive & 11 & $9(82 \%)$ & 0.028 & $2.2(1.1-4.7)$ \\
\hline Negative & 63 & $32(51 \%)$ & & 1 (referent) \\
\hline \multicolumn{5}{|l|}{$p R b>20 \%$} \\
\hline Positive & 61 & $35(57 \%)$ & NS & $1.5(0.6-3.5)$ \\
\hline Negative & 13 & $6(46 \%)$ & & 1 (referent) \\
\hline \multirow{2}{*}{\multicolumn{5}{|c|}{$\begin{array}{l}\text { pRb intensity in tumor } \geq \text { intensity } \\
\text { in adjacent squamous epithelium }\end{array}$}} \\
\hline & & & & \\
\hline Positive & 40 & $25(62 \%)$ & NS & $1.5(0.8-2.9)$ \\
\hline Negative & 34 & $16(47 \%)$ & & 1 (referent) \\
\hline \multicolumn{5}{|l|}{$\mathrm{p} 14^{\mathrm{ARF}}$} \\
\hline Positive & 33 & $12(36 \%)$ & 0.020 & $0.5(0.2-0.9)$ \\
\hline Negative & 41 & $29(71 \%)$ & & 1 (referent) \\
\hline \multicolumn{5}{|l|}{ MDM2 } \\
\hline Positive & 22 & $10(45 \%)$ & NS & $0.8(0.4-1.7)$ \\
\hline Negative & 52 & $31(60 \%$ & & 1 (referent) \\
\hline \multicolumn{5}{|l|}{ p53 } \\
\hline Positive & 37 & 22 (59\%) & NS & $1.2(0.7-2.2)$ \\
\hline Negative & 37 & 19 (51\%) & & 1 (referent) \\
\hline \multicolumn{5}{|l|}{$\mathrm{p} 21^{\text {Cip } 1 / \text { WAF } 1}$} \\
\hline Positive & 30 & $10(33 \%)$ & 0.004 & $0.4(0.2-0.8)$ \\
\hline Negative & 43 & 31 (72\%) & & 1 (referent) \\
\hline Unknown & 1 & & & \\
\hline \multicolumn{5}{|l|}{$\mathrm{p} 27^{\mathrm{KIP} 1}$} \\
\hline Positive & 25 & $14(66 \%)$ & NS & $1.2(0.6-2.3)$ \\
\hline Negative & 47 & $26(55 \%)$ & & 1 (referent) \\
\hline Unknown & 2 & & & \\
\hline
\end{tabular}




\begin{tabular}{|c|c|c|c|c|c|}
\hline Variable & Total & Death & P value ${ }^{1}$ & Unadjusted HR (95\% Cl) & \\
\hline \multicolumn{6}{|c|}{ Clinicopathological Variables } \\
\hline \multicolumn{6}{|l|}{ Gender } \\
\hline Male & 55 & $33(60 \%)$ & \multirow[t]{2}{*}{0.084} & 1 (referent) & \\
\hline Female & 19 & $8(42 \%)$ & & $1,9(0,9-4,2)$ & \\
\hline \multicolumn{6}{|l|}{ Age (years) } \\
\hline$<60$ & 41 & $24(58 \%)$ & \multirow[t]{2}{*}{ NS } & 1 (referent) & \\
\hline$\geq 60$ & 33 & 17 (52\%) & & $0.8(0.4-1.5)$ & \\
\hline \multicolumn{6}{|l|}{ Smoking ${ }^{2}$} \\
\hline No & 11 & $2(18 \%)$ & \multirow[t]{2}{*}{0.006} & 1 (referent) & \\
\hline Yes & 63 & $39(62 \%)$ & & $5.8(1.4-24.1)$ & \\
\hline \multicolumn{6}{|l|}{ Alcohol $^{3}$} \\
\hline No & 29 & $16(55 \%)$ & \multirow[t]{2}{*}{ NS } & 1 (referent) & \\
\hline Yes & 45 & $25(56 \%)$ & & $1.1(0.6-2.0)$ & \\
\hline \multicolumn{6}{|c|}{ Smoking and/or alcohol } \\
\hline No & 8 & $1(12 \%)$ & \multirow[t]{2}{*}{0.015} & 1 (referent) & \\
\hline Yes & 66 & $40(61 \%)$ & & $7.9(1.1-57.7)$ & \\
\hline \multicolumn{6}{|l|}{ Smoking and alcohol } \\
\hline No & 32 & $17(53 \%)$ & \multirow[t]{2}{*}{ NS } & 1 (referent) & \\
\hline Yes & 42 & $24(57 \%)$ & & $1.3(0.7-2.3)$ & \\
\hline \multicolumn{6}{|l|}{ TNM-classification } \\
\hline Stage $0-3$ & 38 & $20(53 \%)$ & \multirow[t]{2}{*}{ NS } & 1 (referent) & \\
\hline Stage 4 & 36 & $21(58 \%)$ & & $1.5(0.8-2.8)$ & \\
\hline \multicolumn{6}{|l|}{ T-classification } \\
\hline$<4 \mathrm{~cm}(\mathrm{~T} 1-2)$ & 35 & $14(40 \%)$ & \multirow[t]{2}{*}{$<0.001$} & 1 (referent) & \\
\hline$\geq 4 \mathrm{~cm}(\mathrm{~T} 3-4)$ & 39 & 27 (69\%) & & $3.1(1.6-6.0)$ & \\
\hline \multicolumn{5}{|l|}{ Tumor grade ${ }^{4}$} & Chapter \\
\hline Poor/ moderate & 61 & $37(61 \%)$ & \multirow[t]{3}{*}{ NS } & 1 (referent) & \\
\hline Well & 10 & $3(30 \%)$ & & $0.4(0.1-1.4)$ & \\
\hline Unknown & 3 & & & & \\
\hline \multicolumn{6}{|l|}{ Lymph node metastasis } \\
\hline Positive & 54 & $29(54 \%)$ & \multirow[t]{2}{*}{ NS } & $1.0(0.5-1.9)$ & \\
\hline Negative & 20 & $12(60 \%)$ & & 1 (referent) & \\
\hline \multicolumn{6}{|l|}{ Recurrent disease } \\
\hline Yes & 16 & $13(81)$ & \multirow[t]{3}{*}{$<0.0001$} & 1 (referent) & \\
\hline No & 32 & $3(9 \%)$ & & $14.1(3.9-51.1)$ & \\
\hline Never disease free & 26 & $25(96 \%)$ & & & \\
\hline \multicolumn{6}{|l|}{ HPV-association } \\
\hline Yes & 26 & $8(31 \%)$ & \multirow[t]{2}{*}{0.010} & $0.4(0.2-0.8)$ & \\
\hline No & 48 & 33 (69\%) & & 1 (referent) & \\
\hline $\begin{array}{l}\text { HR = hazard ratio; NS } \\
{ }^{2} \text { Patiens were classifie } \\
\text { (never smokers or pati } \\
\text { were classified as drin } \\
{ }^{4} \text { Tumor grade was scor } \\
\text { Health Organization }\end{array}$ & $\begin{array}{l}H P V=1 \\
\text { smoker } \\
\text { ed smoki } \\
f>2 \text { whi } \\
\text { ately-, } c\end{array}$ & $\begin{array}{l}\text { n papillome } \\
\text { cigarette, } \\
\text { ore than } 10 \\
\text { equivalents } \\
\text { rly differer }\end{array}$ & $\begin{array}{l}\text { Is. }{ }^{1} \text {-value } \\
\text { pe, and/or } \\
\text { ars before } \\
r \text { day (1 wh } \\
\text { ted accord }\end{array}$ & $\begin{array}{l}\text { based on the Log Rank } t \\
\text { zar per day) or non-smol } \\
\text { diagnosis of TSCC). }{ }^{3} \text { Patie } \\
\text { ey equivalent } ~ 10 \mathrm{~g} \text { alcoh } \\
\text { to the criteria of the W. }\end{array}$ & \\
\hline
\end{tabular}




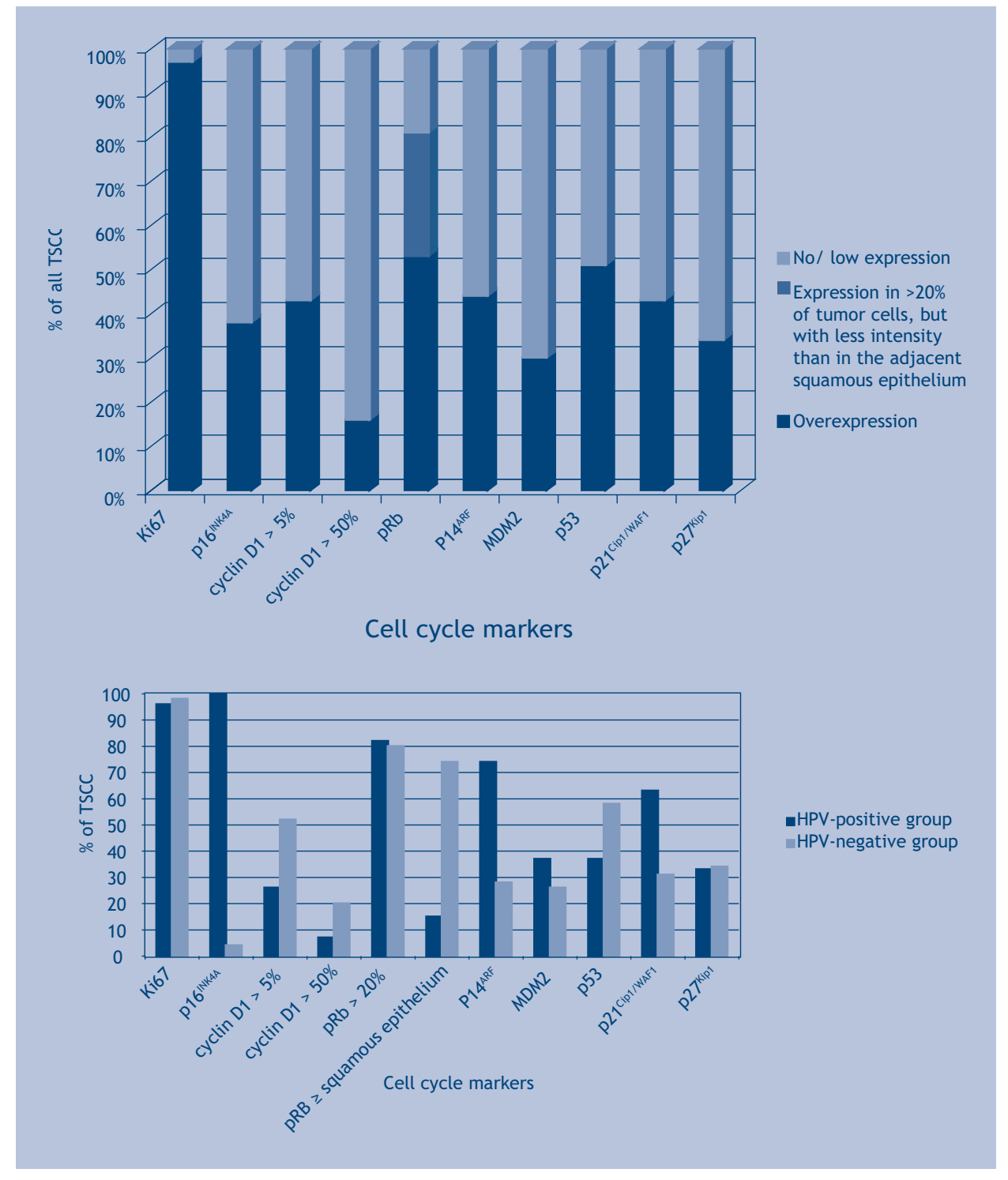

FIGURE 2. (A) CELL CYCLE PROTEIN EXPRESSION IN TSCC ACCORDING TO THE EVALUATION CRITERIA PRESENTED IN TABLE 2. (B) Fraction of HPV-positive and HPV-negative tonsillar squamous cell carcinoma (TSCC) showing expression of individual cell cycle markers. See table 2 for the used criteria for positivity of each individual cell cycle marker. 


\section{Indicators for disease-specific patient survival}

To determine whether or not cell cycle protein expression patterns and clinicopathological parameters can be used as indicators of prognosis, we correlated these with the disease-specific survival data of patients with TSCC (Table 3). Two patients died post-operatively, due to bleeding and aspiration, and from one patient no follow-up data was available. These patients were excluded from the analyses. Follow-up time ranged from 0 to 141 months, with a mean of 30 months. Forty-one (55\%) of 74 patients died as a consequence of TSCC. The survival after 5 years was $31 \%$ for patients with a HPV-negative tumor and $69 \%$ for patients with a HPV-positive carcinoma (Hazard ratio $(\mathrm{HR})=0.4$; 95\% Confidence Interval $(\mathrm{Cl})=0.2-0.8)$. Besides absence of HPV, the following parameters were also significantly associated with a shorter disease-specific survival according to Univariate Cox regression analysis: 1) smoking $(\mathrm{HR}=5.8 ; 95 \% \mathrm{Cl}=1.4-24.1), 2)$ a tumor diameter $\geq 4 \mathrm{~cm}(\mathrm{HR}=3.1 ; 95 \% \mathrm{Cl}=$ 1.6-6.0), 3) development of recurrent disease $(\mathrm{HR}=14.1 ; 95 \% \mathrm{Cl}=3.9-51.1), 4) \mathrm{no} /$ low expression of either p14ARF $(\mathrm{HR}=2.2 ; 95 \% \mathrm{Cl}=1.1-4.3)$ or p21 ${ }^{\mathrm{Cip} 1}$ /WAF1 $1 \mathrm{HR}=2.7$; $95 \% \mathrm{Cl}=1.3-5.5)$, and 5) positive cyclin D1 immunostaining in $>50 \%$ of tumor cells

$(H R=2.2 ; 95 \% \mathrm{Cl}=1.1-4.7)$. Gender, age at diagnosis, alcohol use, tumor grade, TNM-stage, lymph node status and the remaining cell cycle markers were not related to disease-specific survival.

The parameters that were significantly correlated with disease-specific survival in the univariate analysis, i.e. HPV-status, tumor size, smoking, and immunostaining of $\mathrm{p} 14^{\mathrm{ARF}}$, p21 ${ }^{\mathrm{Cip} 1 / \mathrm{WAF} 1}$ and cyclin D1, were included in the multivariate Cox regression analysis. Development of recurrent disease was not included for multivariate analysis, because this factor cannot be predicted at time of diagnosis, so the clinical impact is of less importance. Table 4 shows that 4 of the 6 parameters, i.e. tobacco consumption, tumor diameter $\geq 4 \mathrm{~cm}$, no/ low p21 Cip $1 /$ WAF 1 immunostaining or strong cyclin D1 immunostaining, were the most optimal indicators of cancer-specific death, with tumor size and p21 Cip1/WAF1 immunostaining being the most significantly correlated. In Figure 3 the Kaplan-Meier curves for these 4 parameters are shown. 

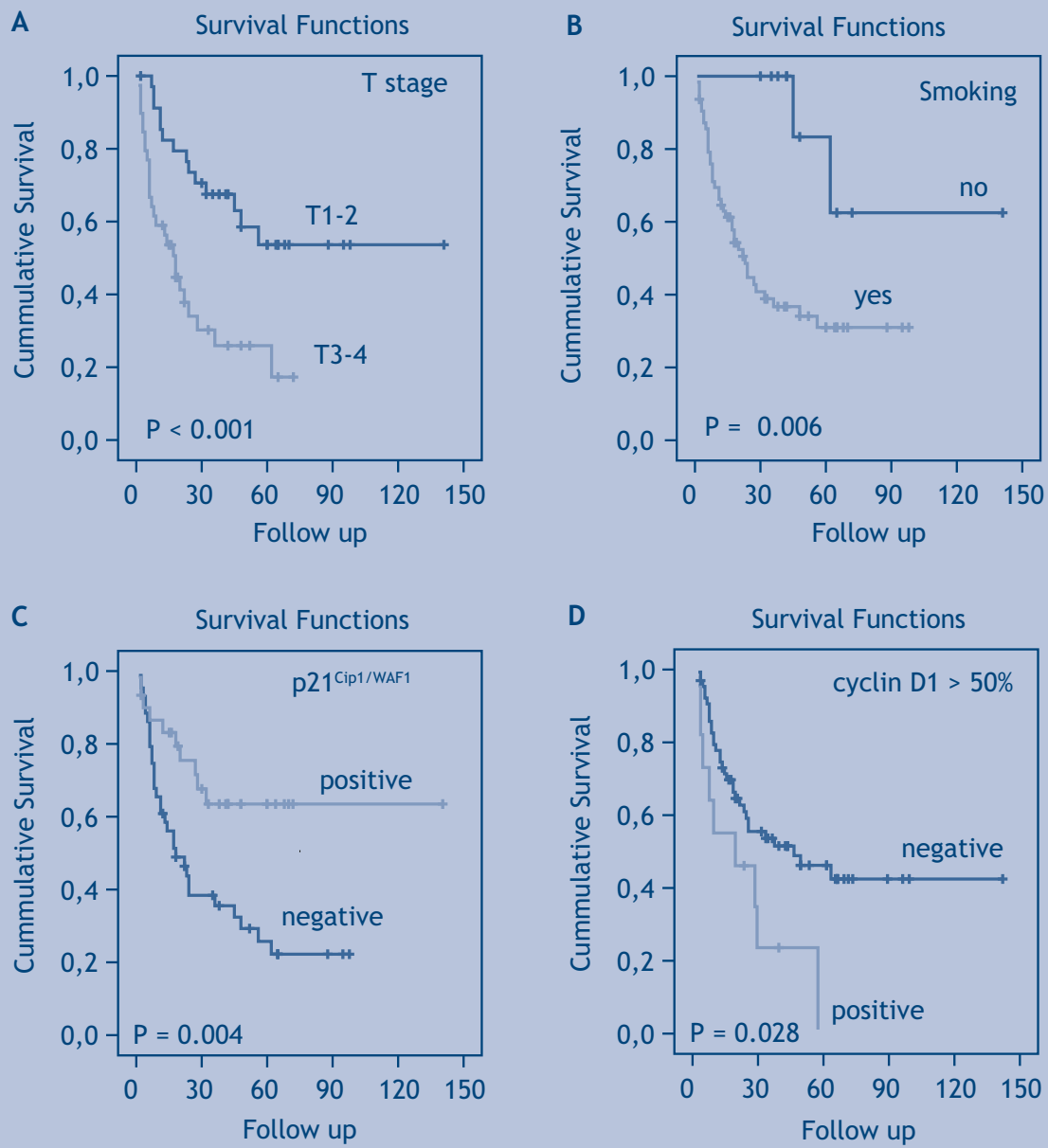

FIGURE 3. KAPLAN-MEIER SURVIVAL CURVES ACCORDING TO (A) TUMOUR SIZE, (B) SMOKING STATUS, (C) P21 CIP1/WAF1 EXPRESSION, AND (D) STRONG CYCLIN D1 EXPRESSION. 
TABLE 4. MULTIVARIATE ANALYSIS, ACCORDING TO COX PROPORTIONAL HAZARD REGRESSION ANALYSIS, OF THE PATIENT AND TUMOR CHARACTERISTICS RELATED TO DISEASE-SPECIFIC MORTALITY

\begin{tabular}{lccc}
\hline Characteristic & HR & $95 \% \mathrm{Cl}$ & P-value \\
\hline Smoking: yes vs. no & 4.06 & $0.95-17.26$ & 0.058 \\
Tumor size: T3-4 vs. T1-2 & 2.58 & $1.32-5.07$ & 0.006 \\
p21 ${ }_{\text {Cip1/WAF1: positive vs. negative }}$ & 0.38 & $0.18-0.79$ & 0.009 \\
cyclin D1: > 50\% vs. $\leq 50 \%{ }^{1}$ & 2.19 & $1.02-4.69$ & 0.044
\end{tabular}

$H R=$ hazard ratio; $\mathrm{Cl}=$ confidence interval. ${ }^{1}$ Nuclear staining

\section{Discussion}

In this study we examined the expression of cell cycle-related constituents in a series of 77 TSCC with the goal to determine their role in HPV-dependent and HPVindependent carcinogenesis. Furthermore, their prognostic value was evaluated by correlating the results with clinical follow-up data. Our results show that HPV16positive tumors exhibit $\mathrm{p} 14^{\mathrm{ARF}}$ and $\mathrm{p} 21^{\mathrm{Cip} 1 / \mathrm{WAF} 1}$ overexpression and downregulation of $\mathrm{pRb}$ and cyclin D1 in contrast to HPV16-negative tumors. Secondly, tumor size and $\mathrm{p} 21^{\mathrm{Cip} 1 / \mathrm{WAF} 1}$ positivity are the strongest independent indicators for a favorable outcome in patients with TSCC.

All TSCC, except one HPV-positive and one HPV-negative tumor, showed a high expression of Ki67, indicating that almost all tumors contained a high percentage of proliferative cells, which is in agreement with other studies on HNSCC 29 . In addition, high expression levels of inhibitors of apoptosis, such as $\mathrm{Bcl} \mathrm{X}_{\mathrm{L}}$ and survivin, have been reported in $\mathrm{HNSCC}^{30-33}$. Expression of pRb was detected in $81 \%$ of TSCC. Approximately half of all tumors showed strong nuclear expression in the tumor cells, with expression levels equal to or higher than the adjacent normal squamous epithelium, whereas pRb downregulation was observed in the remaining cases. In our study p53 overexpression was observed in little more than half of all TSCC, which is consistent with other studies ${ }^{7,34}$. Immunostaining of all other cell cycle proteins was evident in less than $50 \%$ of tumors.

We noticed that the tumors with the low expression levels of pRb showed overexpression of $\mathrm{p} 16^{\mathrm{INK} 4 \mathrm{~A}}$. Accumulation of this latter protein has been strongly associated with the presence of oncogenic HPV in oropharyngeal carcinomas ${ }^{7,10,14,15}$, 
which was also evident in the underlying study. These HPV16-positive TSCC furthermore showed downregulation of cyclin D1, next to accumulation of p14 ARF and p21 Cip1/WAF1. In addition, p53 expression was less profound in these HPV-positive tumors.

In HPV-associated tumors the oncoprotein E7 interacts with pRb, resulting in its degradation. As a result $\mathrm{p} 16^{1 \mathrm{NK} 4 \mathrm{~A}}$ is upregulated and cyclin D1 downregulated ${ }^{35}$. This is in agreement with Andl et al. ${ }^{5}$, who suggested that E7 might overcome the need for cyclin D1 in the $\mathrm{G} 1$ phase of the cell cycle, because it interacts with the cyclin D1-binding site on $\mathrm{pRb}^{7,36}$. Indeed, high expression levels of cyclin D1 were predominantly observed in HPV-negative TSCC, most probably pointing to cyclin D1 gene amplification in these cases.

The $\mathrm{p} 14^{\mathrm{ARF}}$ gene is a target for the transcription factor E2F, which promotes its expression particularly in the HPV-positive tumors, as has become evident in this study. In the HPV-negative tumors both $\mathrm{p} 14^{\mathrm{ARF}}$ as well as $\mathrm{p} 16^{\mathrm{INK} 4 \mathrm{~A}}$ were often undetectable, which is in accordance with the fact that their expression is downregulated in most HNSCC due to gene inactivation at the 9p21 locus ${ }^{37,38}$. In normal tissue cells p14ARF upregulation might lead to p53 upregulation, but in HPV-positive TSCC this is usually counteracted by means of functional inactivation of wild-type p53 by the viral E6 protein. In contrast and as observed in our study, p53 is frequently upregulated in $\mathrm{HPV}$-negative tumors due to mutations in the TP53 gene as a result of exposure to tobacco and/or alcohol $10,16,20,27,39$.

Although p21 Cip1/WAF1 is known to be a downstream effector of $\mathrm{p} 53^{40,41}$, it was surprising to find overexpression in HPV-positive tumors harboring low or no detectable levels of p53. Such observations have also been reported by MildeLangosch et al. ${ }^{42}$ in HPV-associated uterine cervical tumors and suggest that also p53-independent mechanisms may lead to p21 Cip1/WAF1 accumulation as previously described ${ }^{43,44}$. Indeed, in HPV-positive cancer cells p21 Cip1/WAF1 expression appears to be inducible ${ }^{45}$, although it remains unclear why under these conditions E7 cannot inactivate $\mathrm{p}_{21} 1^{\mathrm{Cip} 1 / \text { WAF } 1}$ by direct interaction ${ }^{14}$.

Despite the association of $\mathrm{p} 21^{\mathrm{Cip} 1 / \text { WAF1 }}$ overexpression with HPV-positivity in most TSCC, we found p21 Cip 1 / WAF1 1 protein accumulation in some HPV-negative tumors, which is in accordance with the study of Li et al. ${ }^{46}$. These authors examined 67 TSCC for HPV involvement but did not find p21 Cip1/WAF1 expression being associated with HPV-positivity. An explanation for this paradox might be on the one hand the use of a different p21 Cip1/WAF1 -specific primary antibody and different criteria to assess 
p21 Cip1/WAF1 upregulation (> 20\% of positive nuclei versus $>10 \%$ ) in comparison with our and other studies ${ }^{47-50}$, and on the other hand the use of only PCR to determine the presence of HPV. In order to assess a firm association between virus and tumor cells, namely, it is recommended to carry out additional tests, such as p16 INK4A immunostaining and/or FISH, which has been applied in our study ${ }^{51-52}$.

In the univariate and multivariate statistical analyses we found that p21 Cip1/ WAF1 overexpression was a highly significant indicator of favorable prognosis in TSCC independent of HPV status. Expression of p21 Cip1/WAF1 has also been associated with a favorable survival in patients with tongue squamous cell carcinoma, and in patients with ovarian, superficial bladder, gastric, colorectal and esophageal cancers $35,47,53,54$. In one other study on TSCC and two other studies on laryngeal squamous carcinoma no correlation was reported $46,48,55$ and in one study on HNSCC derived from all head-and-neck localizations even a negative correlation with survival was described ${ }^{19}$, which may be explained by the heterogeneous tumor population. Other strong indicators for a favorable prognosis in our study include tumor diameter < 4cm, low/ no expression of cyclin D1 and low/no tobacco smoking. In accordance with most other studies on HPV-related oropharyngeal carcinomas, we also found a favorable disease-specific survival in patients with HPV16-positive TSCC $^{12,38,56-60}$, and p14ARF overexpression ${ }^{61}$, although with less significance than the indicators described above. We noticed that lymph node status, which is generally considered the most important prognostic factor in $\mathrm{HNSCC}^{23}$, had little value in our series of TSCC, which is in concordance with other studies ${ }^{24,25}$.

In summary we can conclude that HPV16-positive TSCC exhibit overexpression of $\mathrm{p} 14^{\mathrm{ARF}}$ and $\mathrm{p} 21^{\mathrm{Cip} 1 / \mathrm{WAF} 1}$, as well as downregulation of pRb and cyclin D1, while strong immunostaining for p21 Cip1/WAF1 appears to be one of the most potent indicators for favorable prognosis in these tumors. 


\section{References}

1. Parkin DM, Pisani P, Ferlay J. Estimates of the worldwide incidence of 25 major cancers in 1990. Int J Cancer 1999; 80: 827-41.

2. St John MA, Abemayor E, Wong DT. Recent new approaches to the treatment of head and neck cancer. Anticancer Drugs 2006; 17: 365-75.

3. Mao L, Hong WK, Papadimitrakopoulou VA. Focus on head and neck cancer. Cancer Cell 2004; 5: 311-6.

4. Forastiere A, Koch W, Trotti A, Sidransky D. Head and neck cancer. N Engl J Med 2001;345:18901900.

5. Andl T, Kahn T, Pfuhl A, Nicola T, Erber R, Conradt C, et al. Etiological involvement of oncogenic human papillomavirus in tonsillar squamous cell carcinomas lacking retinoblastoma cell cycle control. Cancer Res 1998;58:5-13.

6. Wilczynski SP, Lin BTY, Xie Y, Paz IB. Detection of human papillomavirus DNA and oncoprotein overexpression are associated with distinct morphological patterns of tonsillar squamous cell carcinoma. Am J Pathol 1998;152:145-56.

7. Li W, Thompson CH, Cossart YE, O'Brien CJ, MCNeil EB, Scolyer RA, et al. The expression of key cell cycle markers and presence of human papillomavirus in squamous cell carcinoma of the tonsil. Head Neck 2004; 26: 1-9.

8. Mellin H, Friesland S, Lewensohn R, Dalianis T, Munck-Wikland E. Human papillomavirus (HPV) DNA in tonsillar cancer: clinical correlates, risk of relapse and survival. Int J Cancer 2000; 89: 300-4.

9. Fakhry C, Gillison ML. Clinical implications of human papillomavirus in head and neck cancers. J Clin Oncol 2006; 24: 2606-11.

10. Hafkamp HC, Speel EJ, Haesevoets A, Bot FJ, Dinjens WN, Ramaekers FC, et al. A subset of head and neck squamous cell carcinomas exhibits integration of HPV 16/18 DNA and overexpression of p16 INK4A and p53 in the absence of mutations in p53 exons 5-8. Int J Cancer 2003;107:394-400.

11. Klussmann JP, Weissenborn SJ, Wieland U, Dries V, Kolligs J, Jungehuelsing M, et al. Prevalence, distribution, and viral load of human papillomavirus 16 DNA in tonsillar carcinomas. Cancer 2001;92:2875-84.

12. Ritchie JM, Smith EM, Summersgill KF, Hoffman HT, Wang D, Klussmann JP, et al. Human papillomavirus infection as a prognostic factor in carcinomas of the oral cavity and oropharynx. Int $\mathrm{J}$ Cancer 2003;104:336-44.

13. Hafkamp HC, Manni JJ, Schepers M, Bot FJ, Haesevoets A, Claessen SMH, et al. HPV16-associated

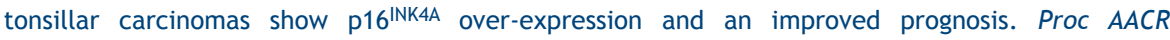
2004;45:93.

14. zur Hausen H. Papillomaviruses and cancer: from basic studies to clinical application. Nat Rev Cancer 2002;2:342-50.

15. Klussmann JP, Gültekin E, Weissenborn SJ, Wieland U, Dries V, Dienes HP, et al. Expression of p16 protein identifies a distinct entity of tonsillar carcinomas associated with human papillomavirus. Am $J$ Pathol 2003;162:747-53.

16. Wiest T, Schwartz E, Enders C, Flechtmacher C, Bosch FX. Involvement of intact HPV 16 E6/E7 expression in head and neck cancers with unaltered p53 status and perturbed pRb cell cycle control. Oncogene 2002;21:1510-7.

17. Reimers N, Kasper HU, Weissenborn SJ, Stutzer H, Preuss SF, Hoffmann TK, et al. Combined analysis of HPV-DNA, p16 and EGFR expression to predict prognosis in oropharyngeal cancer. Int J Cancer 2007;120:1731-8

18. Almadori G, Galli J, Cadoni G, Bussu F, Maurizi M. Human papillomavirus infection and cyclin D1 gene amplification in laryngeal squamous cell carcinoma: biologic function and clinical significance. Head Neck 2002;24:597-604.

19. Erber R, Klein W, Andl T, Enders C, Born Al, Conradt C, et al. Aberrant p21(CIP1/WAF1) protein accumulation in head-and-neck cancer. Int J Cancer 1997;74:383-9. 
20. Haraf DJ, Nodzenski E, Brachman D, Mick R, Montag A, Graves D, et al. Human papilloma virus and p53 in head and neck cancer: clinical correlates and survival. Clin Cancer Res 1996;2:755-62.

21. Paz IB, Cook N, Odom-Maryon T, Xie Y, Wilczynski SP. Human papillomavirus (HPV) in head and neck cancer. Cancer 1997; 79: 595-604.

22. Ragin CC, Taioli E. Survival of squamous cell carcinoma of the head and neck in relation to human papillomavirus infection: review and meta-analysis. Int J Cancer 2007;121:1813-20.

23. Wenzel S, Sagowski C, Kehrl W, Metternich FU. The prognostic impact of metastatic pattern of lymph nodes in patients with oral and oropharyngeal squamous cell carcinomas. Eur Arch Otorhinolaryngol 2004;261:270-5.

24. al-Abdulwahed S, Kudryk W, al-Rajhi N, Hanson J, Jenkins H, Gaedke H, et al. Carcinoma of the tonsil: prognostic factors. J Otolaryngol 1996;26:196-9.

25. Friesland S, Fernberg JO, Lundell G, Munck-Wikland E, Strander H, Lewensohn R. Prognostic impact of complete remission after preoperative irradiation of tonsillar carcinoma: a retrospective analysis of the radiumhemmet data, 1980-1995. Int J Radiat Oncol Biol Phys 1999;45:1259-66.

26. Snijders PJ, Steenbergen RD, Top B, Scott SD, Meijer CJ, Walboomers JM. Analysis of p53 status in tonsillar carcinomas associated with human papillomavirus. J Gen Virol 1994;75:2769-75.

27. Lindel K, Beer KT, Laissue J, Greiner RH, Aebersold DM. Human papillomavirus positive squamous cell carcinoma of the oropharynx: a radiosensitive subgroup of head and neck carcinoma. Cancer 2001;92:805-13.

28. Shanmugaratnam S. Histologic typing of tumors of the upper respiratory tract and ear. Geneva (Switserland): World Health Organization 1991.

29. Pich A, Chiusa L, Navone R. Prognostic relevance of cell proliferation in head and neck tumors. Ann Oncol 2004; 15: 1319-29.

30. Aebersold DM, Kollar A, Beer KT, Laissue J, Greiner RH, Djonov V. Involvement of the hepatocyte growth factor/scatter factor receptor c-met and of Bcl-xL in the resistance of oropharyngeal cancer to ionizing radiation. Int J Cancer 2001; 96: 41-54.

31. Baltaziak M, Duraj E, Koda M, Wincewicz A, Musiatowicz M, Kanczuga-Koda L, et al. Expression of $\mathrm{Bcl}-\mathrm{xL}, \mathrm{Bax}$, and p53 in primary tumors and lymph node metastases in oral squamous cell carcinoma. Ann N Y Acad Sci 2006; 1090: 18-25.

32. Lo Muzio L, Pannone G, Staibano S, Mignogna MD, Rubini C, Mariggio MA, et al. Survivin expression in oral squamous cell carcinoma. Br. J. Cancer 2003; 89: 2244-8.

33. Li F. Survivin study: what is the next wave? J Cell Physiol 2003; 197: 8-29.

34. Friedman M, Lim JW, Manders E, Schaffner AD, Kirshenbaum GL, Tanyeri HM, et al. Prognostic significance of $\mathrm{Bcl}-2$ and p53 expression in advanced laryngeal squamous cell carcinoma. Head Neck 2001; 23: 280-5.

35. Li Y, Nichols MA, Shay JW, Xiong Y. Transcriptional repression of the D-type cyclin-dependent kinase inhibitor p16 by the retinoblastoma susceptibility gene product pRb. Cancer Res 1994; 54: 6078-82.

36. Kim YT, Zhao M. Aberrant cell cycle regulation in cervical carcinoma. Yonsei Med J 2005; 46: 597613.

37. Kamijo T, Zindy F, Roussel MF, Quelle DE, Downing JR, Ashmun RA, et al. Tumor suppression at the mouse INK4a locus mediated by the alternative reading frame product p19ARF. Cell 1997; 91: 64959.

38. Krimpenfort P, Quon KC, Mooi WJ, Loonstra A, Berns A. Loss of p16Ink4a confers susceptibility to metastatic melanoma in mice. Nature 2001; 413: 83-6.

39. Gillison ML, Koch WM, Capone RB, Spafford M, Westra WH, Wu L, et al. Evidence for a causal association between human papillomavirus and a subset of head and neck cancers. $J$ Natl Cancer Inst 2000; 92: 709-20.

40. el-Deiry WS, Tokino T, Velculescu VE, Levy DB, Parsons R, Trent JM, et al. WAF1, a potential mediator of p53 tumor suppression. Cell 1993; 75: 817-25.

41. Harper JW, Adami GR, Wei N, Keyomarsi K, Elledge SJ. The p21 cdk-interacting protein cip 1 is a potent inhibitor of G1 cyclin-dependent kinases. Cell 1993; 75: 805-16. 
62. Klaes R, Friedrich T, Spitkovsky D, Ridder R, Rudy W, Petry U. Overexpression of p16(INK4A) as a specific marker for dysplastic and neoplastic epithelial cells of the cervix uteri. Int J Cancer 2001; 92: 276-84.

63. Takes RP, Baatenburg de Jong RJ, Wijffels K, Schuuring E, Litvinov SV, Hermans J, van Krieken JH. Expression of genetic markers in lymph node metastases compared with their primary tumours in head and neck cancer. Pathol 2001; 194: 298-302.

64. Kumar RV, Kadkol SS, Daniel R, Shenoy AM, Shah KV. Human papillomavirus, p53 and Cyclin D1 expression in oropharyngeal carcinoma. Int J Oral Maxillofac Surg 2003; 32: 539-43. 


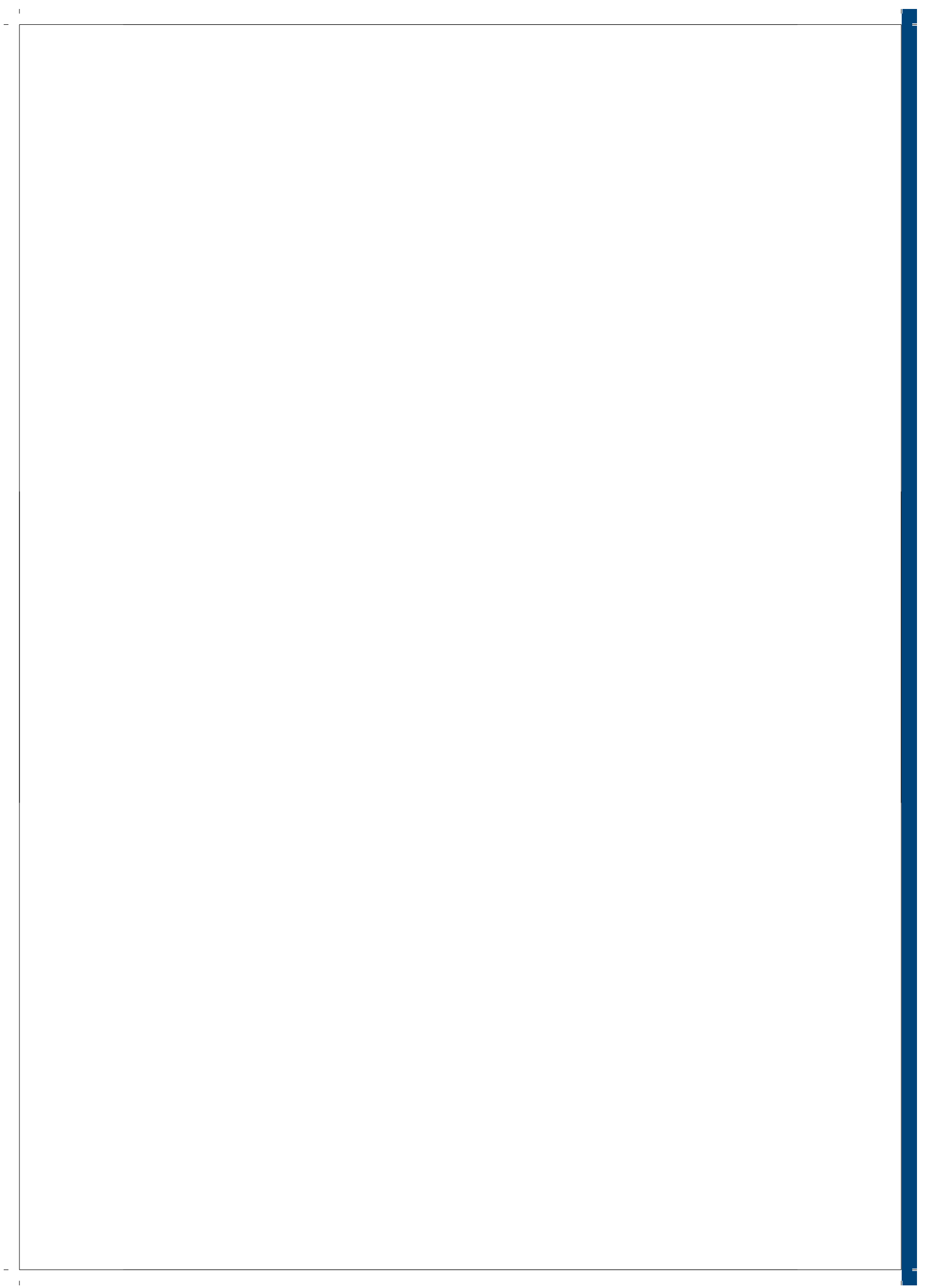




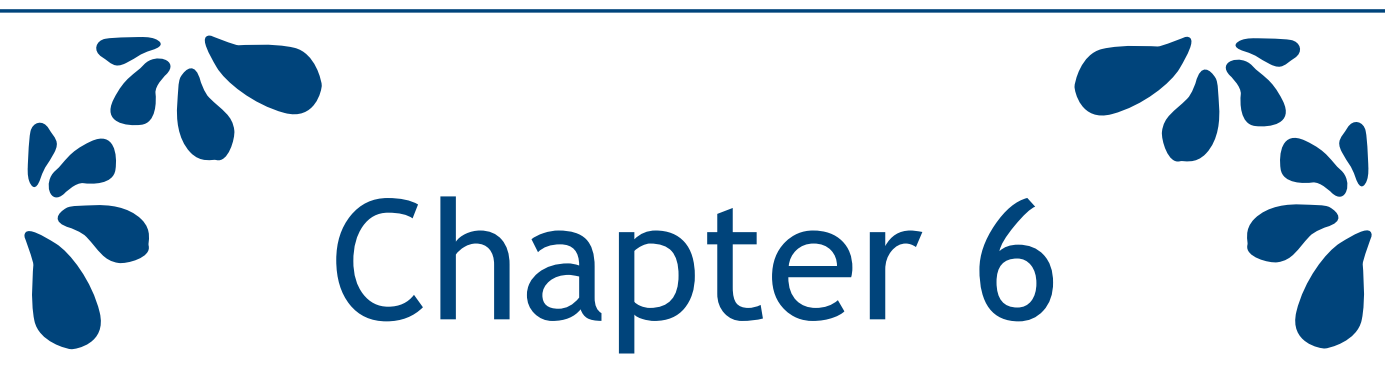

General Discussion

Part of this chapter is published in:

Harriët C. Hafkamp, Johannes J. Manni, Ernst J.M. Speel

Role of human papillomavirus in the development of head and neck squamous cell carcinomas.

Acta Otolaryngol 2004; 124: 520-6.
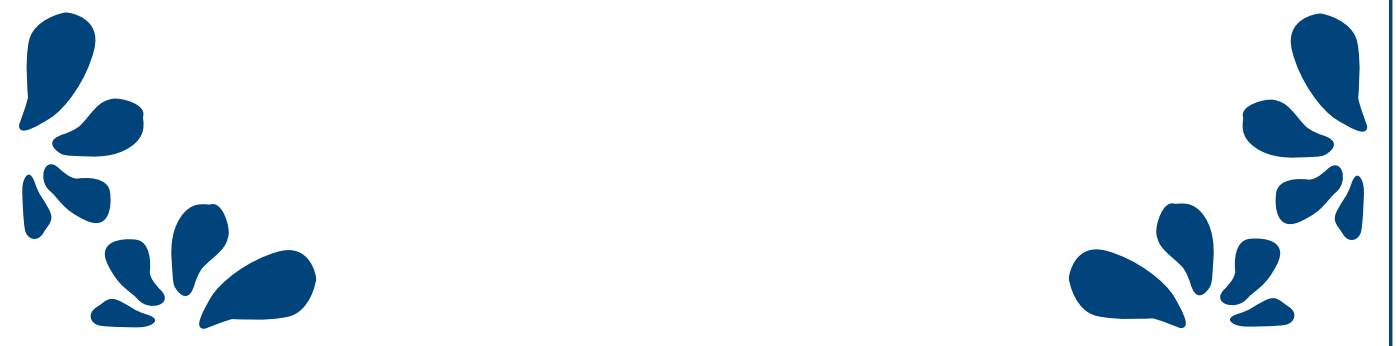


\section{General discussion}

The aim of the studies described in this thesis was to obtain a better insight into the role of oncogenic human papillomaviruses (HPVs) in the carcinogenesis of head and neck squamous cell carcinomas (HNSCC). In this chapter our results will be discussed and related to previous reports in the literature.

\section{Clinical characteristics of HPV-positive carcinomas}

The main clinical and molecular characteristics that seem to differ strongly between HPV-positive and HPV-negative tumors are listed in Table I. We and others have shown that HPV-positive HNSCC are predominantly localized to the oropharynx ${ }^{1-11}$, and that integration of HPV type 16 is involved in almost all cases. The virus has also been detected in lymph-node metastases of these tumors ${ }^{7}$ as well as recently found in dysplasia in the tumor resection margins (Klussmann and Speel, unpublished results). These findings answer the first question raised in Chapter 1. HNSCC containing highrisk HPV appear in general to have a poor differentiation as compared to the often moderate- to well-differentiated HPV-negative tumors ${ }^{3,11-13}$. Furthermore, HPVpositive tumors more often show a characteristic basaloid morphology (meaning an invasive growth pattern as small solid foci) than HPV-negative tumors ${ }^{6,7,12-14}$.

We found that patients with HPV 16-positive tumors presented significantly more often with the initial complaint of a swelling in the neck. This is rather surprising since both HPV-positive and HPV-negative tumors showed comparable percentages of detectable lymph node metastases ${ }^{11,14}$. An explanation for this different presentation might be the significantly smaller primary tumor size (diameter $<4$ $\mathrm{cm}$ ) at the time of diagnosis as found in our patient series with tonsillar squamous cell carcinomas (TSCC) and also described in previous literature ${ }^{11,15}$, leading to less local complaints in the HPV-positive patients. Another explanation may be a better health awareness in patients with HPV 16-positive tumors as reflected by significantly less alcohol and tobacco (ab)use. The significantly smaller HPV-positive primary tumors were accompanied by slightly more regional metastases compared to the HPV-negative tumors, which might suggest that HPV-positive tumors have a tendency to metastasize early. In our study we noticed that the lymph node status, which is generally considered the most important prognostic factor in $\mathrm{HNSCC}^{16}$, had little value in the series of TSCC, which is in concordance with earlier studies ${ }^{17}$. 
A significant correlation between tumor-associated HPV and strongly reduced or absent exposure of patients to the known risk factors of tobacco smoking and alcohol consumption has been reported in our and several other studies $6,7,11,15$. In this respect it was hypothesized that smoking may have a protective effect on HPV infection in the oral cavity and oropharynx due to an increased keratinization of the mucosa. This increased keratinization may protect the mucosa from minor trauma, a situation suggested to be required for HPV infection of the basal cell layer. The finding that tumors of patients with a high tobacco intake are less often infected with HPV seems to support this hypothesis ${ }^{2,6}$. Patients with HPV-containing tumors were reported to be several years younger ${ }^{18-21}$ and more often male ${ }^{14,20}$. In our and other studies, however, this tendency could not be confirmed ${ }^{6,11,22}$.

With respect to the clinical course and prognosis of HPV-related tonsillar squamous cell carcinomas (TSCC), varying observations have been reported. Although most authors described a survival advantage of HPV-positive TSCC patients when compared to HPV-negative cases $^{3,10,14,20,23-28}$, others showed the opposite result ${ }^{29}$ or could not show a difference in survival outcome ${ }^{30,31}$. In addition, it has been suggested that the clinical course of the disease might be gender-specific, since males with a HPV-positive tumor had a better prognosis than males with a HPVnegative tumor, whereas this correlation could not be detected in women ${ }^{14}$.

Despite the fact that patients with HPV-positive TSCC show a favorable prognosis, our study revealed that tobacco smoking is an even stronger prognostic indicator ${ }^{11}$. These findings answer the third question raised in Chapter 1 , and furthermore implicate that oncogenic processes in the tonsillar epithelium of nonsmokers differ from those occurring in smokers, the former being related to HPV 16 infection.

\section{Molecular characteristics of HPV-positive carcinomas}

In addition to clinical features, we and others have described molecular features that are associated with HNSCC harboring high-risk HPV types (Table I). Besides the presence of HPV DNA sequences, tumor cells in most instances show upregulated E6 and E7 oncoprotein expression due to viral integration to the host cell genome, thereby disrupting amongst others the E2 gene sequence and the ability of the E2 protein to down-regulate E6 and E7 transcription. As the HPV E6 oncoprotein promotes 
degradation of $\mathrm{p} 53$, it is expected that $\mathrm{p} 53$ mutations are not a prerequisite in HPVinduced tumorigenesis and that in HPV-positive tumors wild-type p53 expression levels are too low to be detected immunohistochemically. Compared to the reported mutation frequency of approximaly $50 \%$ for the p53 gene in all HNSCC taken together ${ }^{12}$, significantly lower percentages of HPV-containing tumors exhibit p53 mutations in exons 5-8. However, large discrepancies in the number of HPV-positive HNSCC exhibiting simultaneous p53 mutations have been described, ranging from $13 \%$ to $46 \% 32-36$. In two of these studies ${ }^{32,33}$ it was observed that when E6 expression was also taken into account as an additional indicator of a causal relationship between HPV and HNSCC, a maximum of $8 \%$ of HPV-positive tumors harbored p53 mutations. This is in accordance with our FISH study in which we reported an inverse relationship between p53 mutations and the presence of HPV DNA ${ }^{7}$. Despite the lack of p53 mutations in exons 5-8, we ${ }^{7}$ and others ${ }^{23,37}$ also observed an unexpected accumulation of p53 in HPV-containing HNSCC. The molecular mechanisms that may underlie this stabilization and/or overexpression of p53 protein are still unclear. Possible explanations include: (i) the presence of mutations occurring outside exons 5-8; (ii) upregulation of the wild type p53 protein by genotoxic insults, e.g. ultraviolet radiation, or hypoxia ${ }^{38}$; (iii) non-mutational $p 53$ stabilization by $\mathrm{mdm} 2$ or viral proteins such as large T-cell antigen of SV40; and/or (iv) the lack of functional E6 expression e.g. due to a mutation in the gene sequence ${ }^{32}$. The above data answer the second question raised in Chapter 1.

In HPV-positive tumors pRb expression appears to be reduced due to the activity of the $\mathrm{E} 7$ oncoprotein $7,33,39$. As described previously, this will result in upregulation of p16 INK4A expression, previously reported to be a specific surrogate marker for oncogenic HPV-containing (pre)neoplastic lesions of the uterine cervix. Also a downregulation of cyclin D1 synthesis has been observed under these circumstances. We and others ${ }^{40,41}$ also found cyclin D1 downregulation in HPV16-positive TSCC. On the other hand, high expression levels of cyclin D1 were predominantly observed in HPV-negative TSCC, most probably pointing to amplification of the cyclin D1 gene at chromosome $11 \mathrm{q} 13$ in these cases $^{12,42}$.

Whereas $\mathrm{p} 14^{\mathrm{ARF}}$ and $\mathrm{p} 16^{\mathrm{INK} 4 \mathrm{~A}}$ are often undetectable in HPV-negative tumors due to gene inactivation at the $9 \mathrm{p} 21$ locus, we found p14 $\mathrm{ARF}$ and $\mathrm{p} 16^{\text {INK4A }}$ overexpression in our series of HPV 16 -positive tumors ${ }^{11,41}$. The p16 ${ }^{1 \mathrm{NK} 4 \mathrm{~A}}$ overexpression in HPVpositive oropharyngeal cancers has been reported earlier7,43,44. As p16 1NK4A overexpression is highly correlated with HPV status, it is tempting to speculate that 
p16 $16^{\text {NK } 4 \mathrm{~A}}$ overexpression may be used as an additional primary screening method to identify HPV-positive lesions in routine testing ${ }^{7,11,33,43}$.

TABLE I. CLINICAL AND MOLECULAR DIFFERENCES BETWEEN HNSCC WITH OR WITHOUT HIGH-RISK HPV.

\begin{tabular}{lll}
\hline & HPV-positive & HPV-negative \\
Clinical characteristics & oropharynx & all sites \\
\hline Preferred location & poor & well \\
Differentiation & yes & no \\
Basaloid appearance & smaller & larger \\
Size at diagnosis $(\mathrm{D}=4 \mathrm{~cm})$ & more advanced & less advanced \\
Disease stage(TNM) & slightly younger & slightly older \\
Age (about 60 years) & low & high \\
Tobacco (ab)use & low & high \\
Alcohol (ab) use & $55 \%-85 \%$ & $30 \%-55 \%$ \\
5 years disease-free survival & less & more \\
Second primary tumors & less & more \\
Local recurrences & & \\
Molecular characteristics & yes & no \\
HPV DNA & yes & no \\
E6/E7 expression & yes & no \\
P16 overexpression & yes & no \\
P14 overexpression & yes & no \\
P21 overexpression & yes & no \\
PRb down regulation & yes & no \\
Cyclin D1 down regulation & no & yes \\
P16 inactivation & no & yes \\
P53 mutations & no & yes \\
Cyclin D1 amplification & no & yes \\
EGFR overexpression & no & yes \\
Nuclear survivin & &
\end{tabular}

Although p21 Cip1/WAF1 is known to be a downstream effector of p53, several studies describe an overexpression in HPV-positive tumors harboring low or no detectable levels of $p 53^{41,45}$. This finding suggests that also p53-independent mechanisms may lead to $\mathrm{p} 21^{\mathrm{Cip} 1 / \text { WAF1 }}$ accumulation. In our recent study ${ }^{41}$, we found that p21 Cip1/WAF1 overexpression was a highly significant indicator of favorable prognosis in TSCC, independent of HPV status. This association has already been described for patients with tongue squamous cell carcinoma, and in patients with ovarian, superficial bladder, gastric, colorectal and esophageal cancers ${ }^{46,47}$. The above data answer the fifth question raised in Chapter 1. 
In addition to $\mathrm{p} 16^{\mathrm{INK} 4 \mathrm{~A}}$ and $\mathrm{p} 21^{\mathrm{CIP} 1 / \mathrm{WAF} 1}$ as potential prognostic markers for oropharyngeal cancers, the expression of the epidermal growth factor receptor (EGFR) has been in focus as a molecular prognosticator ${ }^{20,48}$. EGFR overexpression appeared to be inversely related to the presence of HPV20,49. Overexpression of EGFR has been associated with local recurrence after radiation and a poor prognosis with respect to disease-free and overall survival in oropharyngeal cancers ${ }^{20,48-50}$.

A recent study by Preuss et al. ${ }^{51}$ has shown an inverse correlation between cytoplasmatic and nuclear survivin localization and HPV-associated carcinomas. Survivin is an inhibitor of apoptosis, with a bifunctional role in apoptosis and in cell division. Overexpression of particularly nuclear survivin has been correlated with poor prognosis, cancer progression and drug resistance ${ }^{51,52}$. However, this finding remains controversial as a recent paper described that nuclear survivin expression predicts a favorable effect on overall survival in oral squamous cell carcinoma ${ }^{53}$. This positive correlation with a better survival was most pronounced in patients treated by radiotherapy, and therefore it was concluded that survivin can be used as a marker to predict a good response to radiotherapy.

Recent comparative genomic hybridization and gene expression profiling studies have reported additional molecular differences between HPV-positive and negative HNSCC, that most likely underlie differences in tumor development and progression and may have prognostic significance ${ }^{42,54-56}$. Marked findings in HPVpositive tumors included the overexpression of several cell cycle regulators ( $\mathrm{p} 16^{\mathrm{INK} 4 \mathrm{~A}}$, p18 and CDC7), transcription factors (TAF7L, RFC4, RPA2 and TFDP2), and genes on chromosome $3 q$. Chromosome $3 q$ loci indeed were found gained or amplified in up to two third of HPV-positive oropharyngeal carcinomas, which may underlie this upregulation of gene expression. However, because $3 q$ gain is also the most frequent chromosomal alteration detected in HPV-negative tumors, more studies are needed to indicate which genes of interest are pivotal in HPV-related and -unrelated HNSCC carcinogenesis. HPV-positive tumors furthermore showed to harbor less chromosomal alterations and amplifications as their HPV-negative counterparts, as well as more often $16 \mathrm{q}$ loss. Particularly the absence of amplifications and the presence of $16 \mathrm{q}$ loss proved to be strong indicators of favorable outcome.

In conclusion, these data provide strong evidence that HPV-positive HNSCCs, particularly oropharyngeal carcinomas, represent a different tumor entity. 


\section{Oropharyngeal carcinogenesis}

From the above we can conclude that there are two separate routes leading to oropharyngeal cancers: one related to the traditional risk factors such as tobacco smoking and alcohol (ab)use, and the other related to infections with oncogenic HPVs (Figure 1). In the HPV-unrelated route, excess of alcohol or tobacco smoke exposure results in deregulation of the p53 and pRb pathways in a multistep process of progression from healthy cell through hyperplasia, dysplasia to finally carcinoma. Predominant molecular alterations include inactivation of $\mathrm{p} 16^{\mathrm{INK} 4 \mathrm{~A}}$ and $\mathrm{p} 14^{\mathrm{ARF}}$ gene expression, p53 mutations and upregulation of EGFR and cyclin D by amongst others gene amplification. In the HPV-related route the oncogenic HPV E6 and E7 proteins act to inactivate p53 and pRb pathways, with subsequent upregulation of p16 ${ }^{\text {INK4A }}$, p14 ${ }^{\mathrm{ARF}}$ and $\mathrm{p} 21^{\mathrm{Cip} 1 / \mathrm{WAF} 1}$ and downregulation of cyclin D1 expression. In Chapter 3 however we describe that there are also tumors in which a combination of the pathways might have taken place. In these cases the human epithelium was exposed to tobacco and alcohol, and meanwhile an infection with an oncogenic HPV has occurred. In these tumors it is unclear which oncogenic events eventually lead to the development from normal epithelium to carcinoma. These tumors may or may not arise via a separate pathway, which needs to be investigated further. In Figure 1 we represent this pathway as an extension of the classical route of carcinogenesis of HPV-negative lesions.

Due to the fact that the total mucosa of the head and neck region is exposed to the carcinogenic effects of tobacco smoking and alcohol use (field cancerization), secondary primary tumors are frequently found in the patients with HPV-negative tumors. In patients with HPV-positive tumors however, we have shown that second primary tumors are uncommon, probably because HPV infection is a rather locally occurring event (Table 1). Why in particular the tonsils are susceptible to HPV infection is unclear at present. Possible explanations can be that: (i) tonsillar epithelium, like the uterine cervix epithelium, is easily accessible and appears to undergo metaplastic processes $^{57}$; (ii) tonsils contain deep invaginations of the mucosal surface (crypts) which create an extensive monolayered epithelial surface which may facilitate viral access to basal cells and intensive antigenic stimulation ${ }^{6,58}$; and (iii) the presence of cytokines produced by lymphoid tissue may affect HPV transcription and cellular transformation ${ }^{57,59}$. 


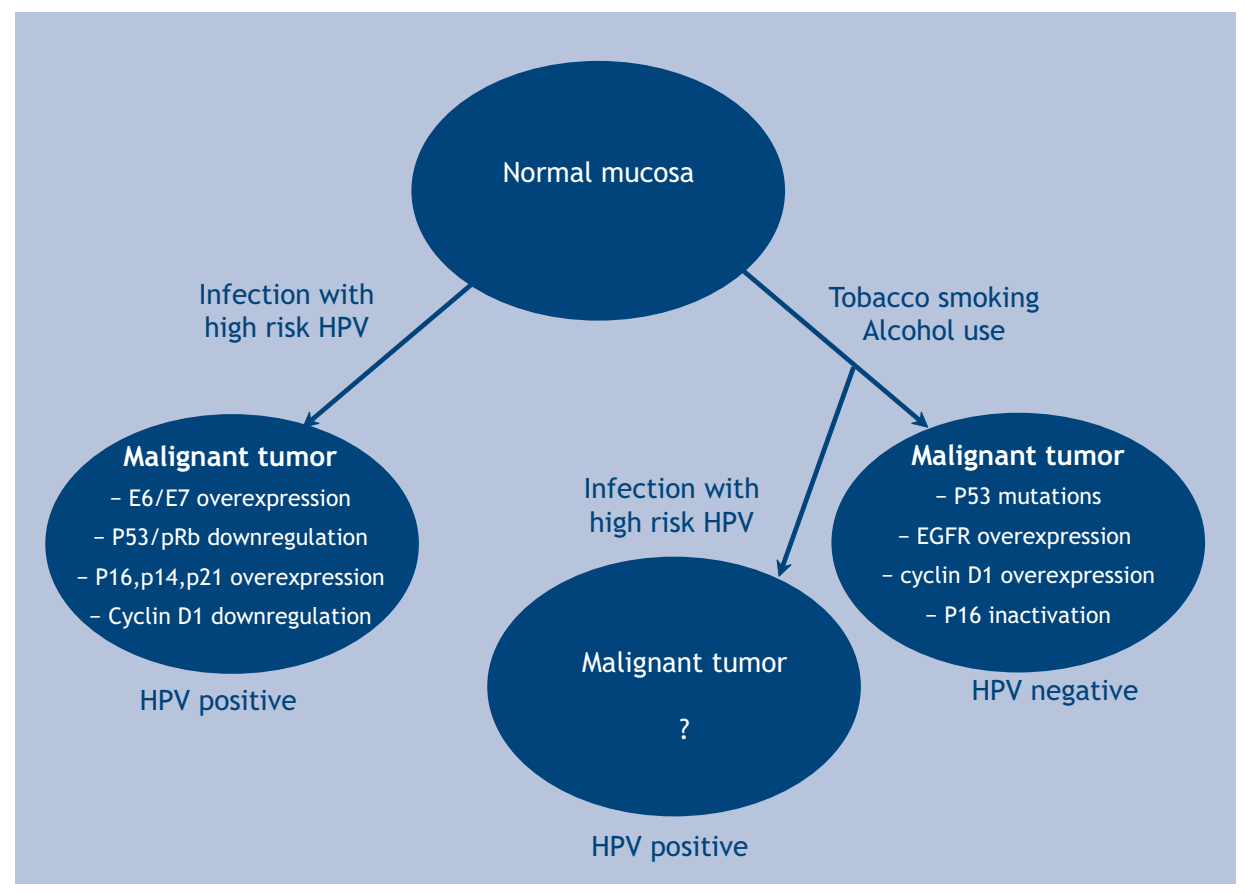

FIGURE 1. PROPOSED MODEL FOR OROPHARYNGEAL CARCINOGENESIS. The model shows three pathways leading to malignancy. In the first pathway the normal mucosa is infected with a high risk human papillomavirus (HPV) leading to expression of E6 and E7 proteins. These proteins cause downregulation of $\mathrm{pRb}$ and $\mathrm{p} 53$, and as a consequence, overexpression of $\mathrm{p} 16^{\mathrm{INK} 4 \mathrm{~A}}, \mathrm{p} 14^{\mathrm{ARF}}$, and p21 CIP1/WAF1 and downregulation of cyclin D1. In the second pathway the mucosa is exposed to tobacco smoke and alcohol leading to P16 ${ }^{\mathrm{INK} 4 \mathrm{~A}}$ inactivation, p53 mutations, as well as EGFR and cyclin D1 overexpression. Finally, in the third pathway the mucosa is exposed to tobacco smoke and alcohol next to an infection with a high risk HPV.

HPV infections of the anogenital tract are known to represent a sexually transmitted disease. However, the route by which HPV reaches the mucosa of the head and neck in adults is not known with certainty. HPV may be acquired through infection at birth and may remain latent for years for unknown reasons. On the other hand it has been reported that husbands of patients with uterine cervical cancer had a higher risk of developing both tonsillar cancer and cancer of the tongue ${ }^{60}$, and that people with a history of oral sex had a fourfold higher chance of HPV infection than those without ${ }^{39,61}$. This finding suggests that oral-genital contact may be a mode of transmission of HPV. Further studies should seek to determine the prevalence 
of HPV in the tonsils of the healthy population in relation to sexual behavior. If the situation in the head and neck region resembles that of the uterine cervix, only a small proportion of patients with HPV infection will develop virus-associated malignancies ${ }^{39}$. This indicates that additional factors are involved in the progression of an infected cell to a transformed cell with invasive potential. Besides the accumulation of genomic alterations data from immunocompromised patients and immuno-manipulated animal models indicate that an impaired immune response is another important factor that leads to tumor progression ${ }^{42,62}$.

\section{Detection of HPV in TSCC}

In our studies we particularly used the fluorescence in situ hybridisation (FISH) technique to detect the presence of HPV. This technique allows the visualization of one copy of HPV DNA in tumor cells, and at the same time the determination of the physical status, i.e. presence of the virus in an integrated versus episomal fashion. HPV 16 proved to be predominantly integrated in TSCC. Our preliminary results moreover show a significant correlation with results of the amplification of papillomavirus oncogene transcript (APOT) assay, an alternative PCR approach to detect integrated HPV ${ }^{11,63}$. Also Koskinen et al. ${ }^{64}$ demonstrated integrated HPV DNA in $>50 \%$ of HPV-positive HNSCC as assessed by a real-time PCR approach comparing the presence of HPV E2 and E6 gene sequences. Although very specific and sensitive, the FISH technology is more time-consuming and expensive than PCR technologies, and therefore not readily suitable for routine practice.

As described earlier $\mathrm{p} 16^{\mathrm{INK} 4 \mathrm{~A}}$ overexpression, as demonstrated by immunohistochemistry, is significantly correlated with HPV 16 DNA integration into the tumor cell genome ${ }^{11}$. P16 ${ }^{1 \mathrm{NK} 4 \mathrm{~A}}$ is a cyclin-dependent kinase inhibitor that prevents pRb phosphorylation and blocks cell cycle progression at the $\mathrm{G} 1$ to $\mathrm{S}$ check point. Loss of $\mathrm{p} 16^{\mathrm{INK} 4 \mathrm{~A}}$ expression by deletion, mutation, or hypermethylation is common in HNSCC. In contrast, functional inactivation of pRb by HPV E7 protein results in overexpression of $\mathrm{p} 16^{\mathrm{INK} 4 \mathrm{~A}}$, which makes it a surrogate marker for HPV. Since p16 $16^{\text {NK } 4 \mathrm{~A}}$ immunohistochemistry is a relatively fast, easy, and cheap approach, it is a good alternative to predict the detection of HPV infection in tonsillar cancer for use in routine practice. The immunohistochemical detection procedure of p16 ${ }^{\text {INK4A }}$ overexpression, however, may remain negative in cases where the gene 
is inactivated, or p16 $16^{\text {NK4A }}$ may become positive in cases where HPV DNA could not be detected, for example due to infection with other viruses or as a result of senescence and physiological aging ${ }^{65,66}$. This seems to be the case in normal, tumor-free tonsil tissue, in which p16 ${ }^{\text {INK } 4 \mathrm{~A}}$ overexpression was unable to predict the presence of HPV67. These findings answer the fourth question raised in Chapter 1.

A frequently used method to detect HPV infections is the polymerase chain reaction $(P C R)^{68}$. In most of the PCR-based HPV detection methods, a broad spectrum of HPV types is amplified by consensus primers, followed by detection with specific probes. Recent studies have shown that oncogenic HPV testing can also be done through detection of the viral mRNA, by reverse transcriptase PCR, even in routinely fixed paraffin embedded tissues ${ }^{69}$. It was hypothesized that the presence of viral E6/ E7 mRNA has a better positive predictive value for malignant transformation than the presence of viral DNA, because the E6/E7 mRNA represents an active infection with cell-transforming potential, whereas the viral DNA may also be present in clinically irrelevant conditions. However, tumors with high levels of E6/E7 mRNA transcripts also showed punctate FISH patterns and p16 ${ }^{\text {INK } 4 \mathrm{~A}}$ overexpression, further underscoring the value of these approaches to detect meaningful HPV association to the tumor ${ }^{69}$. PCR-based methods have a very high analytical sensitivity, with only slight variations between the methods used. On the other hand it appeared that these PCR-based techniques have a relatively low clinical specificity.

Since none of the HPV detection methods have the ideal sensitivity and specificity for routine practice, we advise to use combinations of these detection methods. Testing of p16 $16^{\text {INK } 4 \mathrm{~A}}$ overexpression by immunohistochemistry appears the method of choice for primary screening purposes. In case of $\mathrm{p} 16^{1 \mathrm{NK} 4 \mathrm{~A}}$ overexpression a sensitive PCR based assay can be applied to confirm the presence of HPV and determine which type of HPV is present. Finally, a FISH technique will provide information concerning the physical status of the virus and a direct association with the tumor cells.

\section{Prevention of HPV related TSSC}

The increasing incidence of oropharyngeal cancers might be due to changes in sexual behavior of adolescents in the last decades ${ }^{70}$. As mentioned above, a recent study by D'Souza et al. ${ }^{61}$ has shown that a high lifetime number of vaginal-sex partners and a 
high lifetime number of oral-sex partners was associated with oropharyngeal cancer. There is some evidence that health education programs that promote abstinence, conscientious condom use, or both, could reduce the risk of cervical, and most probably also oropharyngeal cancer at the population level ${ }^{71}$. However, strict condom use is not completely protective against HPV transmission because the male anogenital skin is not completely covered ${ }^{72}$. Thus, the development of HPV L1 viruslike-particle (VLP) vaccines is a potentially major advance in prevention of cervical cancer. These vaccines are based on the self-assembly of recombinant L1 protein into non-infectious capsids that contain no genetic material. Intramuscular injection of the vaccine induces high titers of neutralizing antibody, more than 50 times the titers induced by natural infection ${ }^{73}$. In populations of young adult women without known exposure to HPV-16 and 18, VLP vaccines have shown near perfect efficacy against HPV infection and related cytological and histological endpoints of the cervix for up to 5 years $^{74}$. Whether or not these vaccines also protect against HPV-related oropharyngeal cancer is not clear until now. Important questions do, however, remain with respect to the duration of protection and the total effect on cancer incidence, prevention of infection in men, and the reduction of transmissibility of HPV from men to their partner. Furthermore, it remains a question whether prevention of infection with HPV 16 or HPV18 alters the natural history of other carcinogenic HPVtypes and the number of cervical cancers they cause ${ }^{75}$. Besides these uncertainties concerning the effectiveness of the VLP vaccines in uninfected individuals it has even been suggested that activation of the innate immune mechanisms, that would usually protect against viral infection, may have a more important role in causing disease progression in individuals where the high risk HPV DNA integration has already taken place ${ }^{76}$. The mechanism underlying this disease progression process includes the loss of the episome-derived E2 protein. Recent work has suggested that the episome-derived E2 protein inhibits transcription of the integrated HPV-DNA, thereby creating an important intermediate stage in cervical carcinogenesis where transcriptionally silent HPV integration co-exists with viral episomes ${ }^{76,77}$.

Another cause of the increasing number of patients with tonsillar carcinomas might be the decreased number of tonsillectomies performed at younger age in some countries. In the Netherlands for instance the rate of pediatric tonsillectomies with or without adenotomy decreased rapidly between 1974 and $1985^{78}$. In other countries, such a decrease could not be found. It is unclear whether the increased incidence of tonsillar carcinomas in the Netherlands is a result from a decreased rate 
of tonsillectomies. Well performed population based studies linking tonsillectomy rates and incidence rates of tonsillar carcinomas over many years should shed further light on this subject.

\section{Therapy of oropharyngeal cancers}

About $50 \%$ of patients with oropharyngeal cancers survive more than 5 years after first diagnosis. Mortality rates of patients with HNSCC have, however, not improved substantially over the past decades, despite advances in diagnosis and therapy ${ }^{79}$. In order to improve outcome it is necessary to identify patients who will respond to a particular therapy. Surgery affects structures important for food uptake, swallowing and speach. Organ-sparing therapies, such as radiation or chemotherapy, can lead to improved outcomes in patients who respond to such therapy. Different studies are undertaken to improve the understanding of the biology of resistance to chemo- or radiation therapy in order to develop effective alternative treatments.

We found that patients with HPV 16-positive tumors had a significantly better disease-specific and overall survival compared to patients with HPV 16-negative tumors. It has been suggested that this better survival outcome might result from a better response to radiation- and chemotherapy ${ }^{80,81}$. An explanation for this better response may be the fact that although the pRb and p53 pathways are compromised in HPV-positive tumors they retain some function, such that under the pressure of chemotherapy or radiotherapy p53-mediated apoptotic pathways may still function. Another reason for the better survival outcome in patients with HPV-positive tumors might be the significantly lower chance of developing a second primary tumor ${ }^{3}$, because patients with HPV-positive tumors show often low or no tobacco and alcohol intake and HPV infection tends to be focal. Our data are in agreement with these suggestions, because we noticed a significantly lower tobacco and alcohol intake in HPV-positive tumor patients, as well as a lower percentage of (loco)regional recurrences, and found only second primary tumor development in the HPV-negative patient group ${ }^{11}$.

In order to further identify patients that will respond to a particular therapy, different molecular biomarkers, sex and smoking status have been examined for their correlation to treatment outcome.

The presence of p53 mutations was not linked to treatment response or survival 
in different studies ${ }^{21,49}$. It appeared that overexpression of the anti-apoptotic proteins $\mathrm{Bcl}-2$ and $\mathrm{Bcl}-\mathrm{xL}$ is associated with chemotherapy and radiation resistance ${ }^{28}$. The combination of a low p53 and low Bcl-xL expression however was correlated to a better overall and disease specific survival, which is in accordance with the observed apoptotic process in HNSCC tumor cells in response to chemotherapy in in vitro studies ${ }^{49}$.

Kumar et al. ${ }^{20,21}$ also reported a poor response to organ-sparing therapy in smoking female patients, with a high EGFR expression in the tumor. It appeared that EGFR expression was significantly higher in smokers, which suggests that smoking may contribute to up-regulation of EGFR expression, through increased hypoxia in the tumor tissue.

This finding suggests that non-smoking male patients with HPV-positive tumors, with low EGFR, low p53 and low Bcl-xL expression may benefit the most from chemo- and radiation therapy. However, before these findings are implemented in treatment protocols, more extensive studies must be performed.

Furthermore, alternative treatment strategies must be developed for those patients that benefit to a more limited extent from chemotherapy, radiation therapy and surgery.

\section{Possible future therapies}

To improve the therapeutic outcome of HPV-related HNSCC the use of antiviral drugs, such as the acyclic nucleoside phosphonate cidofovir, is being investigated for clinical applications ${ }^{82-84}$. Local injection of cidofovir in immunocompetent patients with recurrent respiratory papillomatosis resulted in complete disappearance or partial remission of the lesions, which appears to be based on the induction of apoptosis. This process was associated with accumulation of the tumor suppressor proteins $\mathrm{p} 53$ and $\mathrm{pRb}$ and the cyclin-dependent kinase inhibitor p21Cip1/WAF1 85. Administration of cidofovir to HPV-positive cancer cell lines showed a down-regulation of E6 and $\mathrm{E7}$, with subsequent reactivation of p53 and pRb, and induction of p21 Cip1/WAF1 83. Combining cidofovir with irradiation both in vivo and in nude mice xenografts resulted in a marked radiosensitization of HPV-positive cells ${ }^{83}$. In another study where a naturally HPV-16 transformed HNSCC cell line was used, administration of cidofovir showed only a marginally reduced HPV-16 gene transcription and a modest 
p53 restorative effect. In combination with irradiation the effect of cidofovir was enhanced ${ }^{84}$. These studies may provide the basis for a new anticancer strategy, in which cidofovir is used to enhance the antitumor effect of radiation therapy in HPVrelated cancers. More studies will be required to evaluate its therapeutic potential and to optimize its clinical usefulness.

As a future perspective, targeted use of EGFR inhibitors in patients with high tumor EGFR expression could improve survival outcome of HNSCC patients. The combined use of specific monoclonal antibodies and tyrosine kinase inhibitors appears very promising in this respect 86,87 . Such monoclonal antibodies bind to the extracellular domain of EGFR, preventing ligand binding, aggregation or internalization of the EGFR, thereby interrupting the signaling cascade. Tyrosine kinase inhibitors bind to the intracellular domain of EGFR and inhibit the downstream effects of EGFR ligand binding. Blocking EGFR signaling has been shown to effectively reduce HNSCC aggressive cell phenotypes, to inhibit angiogenesis, and induce cancer cell death (apoptosis) in a subset of patients ${ }^{86}$. However, because EGFR overexpression appears to be inversely related to the presence of HPV in oropharyngeal carcinomas ${ }^{48}$, EGFRdirected therapy might be of less value in the treatment of these HPV-positive HNSCC.

Another therapeutic target might be the insulin-like growth factor type 1 receptor (IGF-1R), since it was shown that the expression of this receptor is increased in HNSCC and that IGF-1R signaling significantly influences proliferation, motility and tumorigenicity ${ }^{88}$.

Survivin, an inhibitor of apoptosis, has become of interest in cancer research since it is often upregulated in different types of malignant lesions ${ }^{51}$. Targeting survivin may provide a novel therapy and several clinical trials targeting survivin with immunotherapy and antagonists are under way, which might lead to a broadly applicable therapy ${ }^{89}$.

Another new treatment modality mentioned in the literature is the use of resveratrol, a polyphenol with reported antiangiogenic effects found at high concentrations in grapes and red wine. This agent may be particularly effective in HPV-positive tumors since it appears that HPV 16 oncoproteins promote tumor angiogenesis. For example, an in vitro study has shown that resveratrol could abolish capillary and tubule formation initiated by the E6 and E7 oncoproteins in HPV 16 positive cervical cancer cells ${ }^{90}$. 
Finally, targeted inhibition of the E6 and E7 oncogenes in HPV-related cancers is a rational approach toward the development of additional cancer therapy. Evidence from in vitro studies has shown that inhibition of these viral oncogenes by gene therapy approaches, such as antisense RNA and small interfering RNA, results in loss of the transformed phenotype of the cells ${ }^{91,92}$. The loss of E6 and E7 resulted in massive apoptosis in HPV 16-related cancer cells by activating cellular p53, p21 and $\mathrm{pRb}^{93}$. These studies suggest that gene therapy against the viral oncogenes E6 and E7 could be advantageous in promoting better outcomes for patients with HPV-related cancers. Since there is no effective delivery mechanism for anti HPV gene therapy thus far, the challenge now is to turn these research findings into meaningful clinical applications.

\section{Concluding remarks and future perspectives}

We can conclude that HNSCC associated with high-risk HPV types show substantial differences in histology, risk factors, expression of cell cycle proteins and prognosis in comparison with HPV-negative tumors. This supports the view that HPV-positive HNSCC can be considered a different tumor entity with a favorable response to radio- and chemotherapy, which improves the prognoses of patients with HPVpositive tumors compared to those with HPV-negative tumors.

If the HPV vaccination therapy for prevention of cervical neoplasia would be applied to both uninfected boys and girls, the annual increase in the incidence of oropharyngeal cancers might be stopped in the near future. Studies concerning the therapeutic properties of HPV vaccines may lead to the development of additional therapeutic possibilities to eradicate tumor cells and/or dysplastic lesions as well as circulating micrometastases (minimal residual disease) still present after tumor resection. Screening of HNSCC, and particularly oropharyngeal and tonsillar cancers, for the presence of integrated HPV DNA and/or p16 ${ }^{\text {INK4A }}$ overexpression may help to optimize treatment protocols and to provide more accurate prognostic information.

In addition, studies should be started to elucidate questions with respect to: (i) the prevalence of high-risk HPV in, for example, the tonsils of healthy people; (ii) the transmission and natural course of HPV infection in the oropharynx; and (iii) the molecular mechanisms underlying the progression of HPV-associated HNSCC. 


\section{References}

1. Paz IB, Cook N, Odom-Maryon T, Xie Y, Wilczynski SP. Human papillomavirus (HPV) in head and neck cancer. An association of HPV 16 with squamous cell carcinoma of Waldeyer's tonsillar ring. Cancer 1997;79:595-604.

2. McKaig RG, Baric RS, Olshan AF. Human papillomavirus and head and neck cancer: epidemiology and molecular biology. Head \& Neck 1998;20:250-65.

3. Gillison ML, Koch WM, Capone RB, Spafford M, Westra WH, Wu L, Zahurak ML, Daniel RW, Viglione $M$, Symer DE, Shah KV, Sidransky D. Evidence for a causal association between human papillomavirus and a subset of head and neck cancers. J Natl Cancer Inst 2000;92:709-20.

4. Snijders PJ, Cromme FV, van den Brule AJ, Schrijnemakers HF, Snow GB, Meijer CJ, Walboomers JM. Prevalence and expression of human papillomavirus in tonsillar carcinomas, indicating a possible viral etiology. Int J Cancer 1992;51:845-50.

5. Mork J, Lie AK, Glattre E, Hallmans G, Jellum E, Koskela P, Moller B, Pukkala E, Schiller JT, Youngman $\mathrm{L}$, Lehtinen $\mathrm{M}$, Dillner J. Human papillomavirus infection as a risk factor for squamous-cell carcinoma of the head and neck. N Engl J Med 2001;344:1125-31.

6. Klussmann JP, Weissenborn SJ, Wieland U, Dries V, Kolligs J, Jungehuelsing M, Eckel HE, Dienes HP, Pfister HJ, Fuchs PG. Prevalence, distribution, and viral load of human papillomavirus 16 DNA in tonsillar carcinomas. Cancer 2001;92:2875-84.

7. Hafkamp HC, Speel EJ, Haesevoets A, Bot FJ, Dinjens WN, Ramaekers FCS, Hopman AH, Manni JJ. A subset of head and neck squamous cell carcinomas exhibits integration of HPV 16/18 DNA and overexpression of p16 ${ }^{\mathrm{NK} 4 \mathrm{~A}}$ and $\mathrm{p} 53$ in the absence of mutations in p53 exons 5-8. Int J Cancer 2003;107:394-400. (chapter 2).

8. Fouret P, Monceaux G, Temam S, Lacourreye L, St Guily JL. Human papillomavirus in head and neck squamous cell carcinomas in nonsmokers. Arch Otolaryngol Head Neck Surg 1997;123:513-6.

9. Wittekindt C, Gültekin E, Weissenborn SJ, Dienes HP, Pfister HJ, Klussmann JP. Expression of p16 protein is associated with human papillomavirus status in tonsillar carcinomas and has implications on survival. Adv Otorhinolaryngol 1005;62:72-80.

10. Fakhry C, Gillison ML. Clinical implications of human papillomavirus in head and neck cancers. Journal of Clinical Oncology 2006;24:2606-11.

11. Hafkamp HC, Manni JJ, Haesevoets A, Voogd AC, Schepers M, Bot FJ, Hopman AHN, Ramaekers FCS, Speel EJ. Marked differences in survival rate between smokers and non-smokers with HPV 16 associated tonsillar carcinomas. Int J Cancer 2008;122:2656-64. (chapter 3)

12. Forastiere A, Koch W, Trotti A, Sidransky D. Head and neck cancer. N Engl J Med 2001;345:18901900.

13. Wilczynski SP, Lin BT, Xie Y, Paz IB. Detection of human papillomavirus DNA and oncoprotein overexpression are associated with distinct morphological patterns of tonsillar squamous cell carcinoma. Am J Pathol 1998;152:145-56.

14. Ritchie JM, Smith EM, Summersgill KF, Hoffman HT, Wang D, Klussmann JP, Turek LP, Haugen $\mathrm{TH}$. Human papillomavirus infection as a prognostic factor in carcinomas of the oral cavity and oropharynx. Int J Cancer 2003;104:336-44.

15. Hafkamp HC, Manni JJ, Schepers M, Bot FJ, Haesevoets A, Claessen SMH, Hopman AH, Ramaekers FC, Speel EJ. Integration of genomic HPV16 DNA is associated with p16 INK4A overexpression in tonsillar carcinomas. J Cancer Res Clin Oncol 2003;129(Supl2):S36 (abstract TH23).

16. Wenzel S, Sagowski C, Kehrl W, Metternich FU. The prognostic impact of metastatic pattern of lymph nodes in patients with oral and oropharyngeal squamous cell carcinomas. Eur Arch Otorhinolaryngol. 2004; 261:270-5.

17. al-Abdulwahed S, Kudryk W, al-Rajhi N, Hanson J, Jenkins H, Gaedke H, Jha N. Carcinoma of the tonsil: prognostic factors. J Otolaryngol. 1996;26:196-9.

18. Sisk EA, Bradford CR, Jacob A, Yian CH, Staton KM, Tang G, Harris MO, Carey TE, Lancester WD, Gregoire L. Human papillomavirus infection in "young" versus "old" patients with squamous cell carcinoma of the head and neck. Head \& Neck 2000; 22:649-57. 
19. Li W, Thompson CH, Cossart YE, O'Brien CJ, McNiel CB, Scolyer RA, Rose BR. The expression of key cell cycle markers and presence of human papillomavirus in squamous cell carcinoma of the tonsil. Head \& Neck 2004;26:1-9.

20. Kumar B, Cordell KG, Lee JS, Prince ME, Tran HH, Wolf GT, Urba SG, Worden FP, Chepeha DB, Teknos TN, Eisbruch A, Tsien CI, Taylor JMG, D’Silva NJ, Yang K, Kurnit DM, Bradford CR, Carey TE. Response to therapy and outcomes in oropharyngeal cancer are associated with biomarkers including human papillomavirus, epidermal growth factor receptor, gender, and smoking. Int.J.Radiation Oncology Biol. Phys 2007;69:S109-11.

21. Kumar B, Cordell KG, Lee JS, Worden FP, Prince ME, Tran HH, Wolf GT, Urba SG, Chepeha DB, Teknos TN, Eisbruch A, Tsien Cl, Taylor JMG, D'Silva NJ, Yang K, Kurnit DM, Bauer JA, Bradford CR, Carey TE. EGFR, p16, HPV titer, Bcl-xL and p53, sex, and smoking as indicators of response to therapy and survival in oropharyngeal cancer. J Clin Oncol 2008;26:3128-37.

22. Chatuvedi AK, Engels EA, Anderson WF, Gillison ML. Incidence trends for human papilomavirus-related and -unrelated oral squamous cell carcinomas in the United States. J Clin Oncol 2008;26:612-9.

23. Sisk EA, Soltys SG, Zhu S, Fisher SG, Carey TE, Bradford CR. Human papillomavirus and p53 mutational status as prognostic factors in head and neck carcinoma. Head \& Neck 2002;24:841-9.

24. Schwartz SR, Yueh B, McDougall JK, Daling JR, Schwartz SM. Human papillomavirus infection and survival in oral squamous cell cancer: a population-based study. Otolaryngol Head Neck Surg 2001;125:1-9.

25. Chiba I, Shindoh M, Yasuda M, Yamazaki Y, Amemiya A, Sato Y, Fujinaga K, Notani K, Fukada H. Mutations in the $\mathrm{p} 53$ gene and human papillomavirus infection as significant prognostic factors in squamous cell carcinomas of the oral cavity. Oncogene 1996;12:1663-8.

26. Li W, Thompson CH, O’Brien CJ, McNiel EB, Scolyer RA, Cossart YE, Veness MJ, Walker DM, Morgan GJ, Rose BR. Human papillomavirus positivity predicts favourable outcome for squamous carcinoma of the tonsil. Int J Cancer 2003;106:553-8.

27. Gillison ML. Human papillomavirus and prognosis of oropharyngeal squamous cell carcinoma: implications for clinical research in head and neck cancers. J Clin Oncol 2006; 36:5623-5.

28. Reed JC, Miyashita T, Takayama S, Wang HG, Krajewski S, Aimé-Sempé C, Bodrug S, Kitada S, Hanada M. BCL-2 family proteins: Regulators of cell death involved in the pathogenesis of cancer and resistance to therapy. J Cell Biochem 1996; 60:23-32.

29. Clayman GL, Stewart MG, Weber RS, el-Naggar AK, Grimm EA. Human papillomavirus in laryngeal and hypopharyngeal carcinomas. Relationship to survival. Arch Otolaryngol Head Neck Surg 1994;120:743-8.

30. Strome SE, Savva A, Brissett AE, Gostout BS, Lewis J, Clayton AC, McGovern R, Weaver AL, Persing D, Kasperbauer JL. Squamous cell carcinoma of the tonsils: a molecular analysis of HPV associations. Clin Cancer Res 2002;8:1093-100.

31. Haraf DJ, Nodzenski E, Brachman D, Mick R, Montag A, Graves D, Vokes EE, Weichselbaum RR. Human papilloma virus and p53 in head and neck cancer: clinical correlates and survival. Clin Cancer Res 1996;2:755-62.

32. Van Houten VM, Snijders PJ, Van den Brekel MW, Kummer JA, Meijer CJLM, van Leeuwen B, Denkers F, Smeele LE, Snow GB, Brakenhoff RH. Biological evidence that human papillomaviruses are etiologically involved in a subgroup of head and neck squamous cell carcinomas. Int J Cancer 2001; 93:232-5.

33. Wiest T, Schwartz E, Enders C, Flechtmacher C, Bosch FX. Involvement of intact HPV E6/E7 expression in head and neck cancers with unaltered p53 status and perturbed pRb cell cycle control. Oncogene 2002;21:1510-7.

34. Snijders PJF, Steenbergen RDM, Top B, Scott SD, Meijer CJLM, Walboomers JMM. Analysis of p53 status in tonsillar carcinomas associated with human papillomavirus. J Gen Virol 1994;75:2769 -75.

35. Barten M, Ostwald C, Mildelangosch K, Muller P, Wukasch Y, Loning T. HPV DNA and p53 alterations in oropharyngeal carcinomas. Virchows Arch 1995;427:153-7.

36. Scholes AGM, Liloglou T, Snijders PJF, et al. p53 mutations in relation to human papillomavirus type 16 infection in squamous cell carcinomas of the head and neck. Int J Cancer 1997;71:796 -9. 
54. Smeets SJ, Braakhuis BJ, Abbas S, Snijders PJ, Ylstra B, van de Wiel MA, Meijer GA, Leemans $\mathrm{CR}$, Brakenhoff RH. Genome-wide DNA copy number alterations in head and neck squamous cell carcinomas with or without oncogene-expressing human papillomavirus. Oncogene 2006;25:255864.

55. Slebos RJ, Yi Y, Ely K, Carter J, Evjen A, Zhang X, Shyr Y, Murphy BM, Cmelak AJ, Burkey BB, Netterville JL, Levy S, Yarbrough WG, Chung CH. Gene Expression Differences Associated with Human Papillomavirus Status in Head and Neck Squamous Cell Carcinoma. Clin Cancer Res 2006;12:701-9.

56. Schlecht NF, Burk RD, Adrien L, Dunne A, Kawachi N, Sarta C, Chen Q, Brandwein-Gensler M, Prystowsky MB, Childs G, Smith RV, Belbin TJ. Gene expression profiles in HPV-infected head and neck Cancer. J Pathol 2007;213:283-93.

57. Wilczynski SP, Lin BTY, Xie Y, Paz IB. Detection of human papillomavirus DNA and oncoprotein overexpression are associated with distinct morphological patterns of tonsillar squamous cell carcinoma. Am J Pathol 1998;152:145-56.

58. Kim SH, Koo BS, Kang S, Park K, Kim H, Lee KR, Lee MJ, Kim JM, Choi EC, Sho NH. HPV integration begins in the tonsillar crypt and leads to the alteration of p16, EGFR and c-myc during tumor formation. Int J Cancer 2007;120:1418-25.

59. Francesschi S, Munoz N, Snijders PJF. How strong and how wide is the link between HPV and oropharyngeal cancer? Lancet 2000;356:871-2.

60. Hemminki K, Dong C, Frisch M. Tonsillar and other upper aerodigestive tract cancers among cervical cancer patients and their husbands. Eur J Cancer Prev 2000;9:433-7.

61. D'Souza G, Kreimer AR, Viscidi R, Pawlita M, Fakhry C, Wayne MK, Westra WH, Gillison ML. Casecontrol study of human papillomavirus and oropharyngeal cancer. N Engl J Med 2007; 356: 1944-56.

62. Tindle RW. Immune evasion in human papillomavirus-associated cervical cancer. Nat Rev Cancer 2002;2:59-65.

63. Wentzensen N, Vinokurova S, von Knebel Doeberitz M. Systematic review of genomic integration sites of human papillomavirus genomes in epithelial dysplasia and invasive cancer of the female lower genital tract. Cancer Res 2004;64:3878-84.

64. Koskinen WJ, Chen RW, Leivo I, Mäkitie A, Bäck L, Kontio R, Suuronen R, Lindqvist C, Auvinen E, Molijn A, Quint WG, Vaheri A, Aaltonen LM. Prevalence and physical status of human papillomavirus in squamous cell carcinomas of the head and neck. Int J Cancer 2003;107:401-6.

65. Castillo JP, Kowalik TF. Human cytomegalovirus immediate early proteins and cell growth control. Gene 2002;290:19-34.

66. Helt A-M, Galloway DA. Mechanisms by which DNA tumor virus oncoproteins target Rb family of pocket proteins. Carcinogenesis 2003;24:159-69.

67. Klingenberg B, Hafkamp H.C., Haesevoets A, Manni JJ, Slootweg PJ, Weissenborn SJ, Klussmann JP, Speel EJM. P16 INK4A overexpression is requently detected in tumor-free tonsil tissue without association with HPV. Submitted for publication. (chapter 4).

68. Brink ATP, Snijders PJF, Meijer CJLM. HPV detection methods. Disease markers 2007;23:273-81.

69. Smeets SJ, Hesselink AT, Speel EJM, Haesevoets A, Snijders PJF, Pawlita M, Meijer CJLM, Braakhuis BJM, Leemans CR, Brakenhoff RH. A novel algorithm for reliable detection of human papillomavirus in paraffin ebedded head andneck cancer specimen. Int.J.Cancer 2007;121:2465-72.

70. Mosher WD, Chandra A, Jones J. Sexual behavior and selected health measures: men and women 15-44 years of age, United States, 2002. Adv Data 2005;362:1-55.

71. Shepherd J, Weston R, Peersman G, Napuli IZ. Interventions for encouraging sexual lifestyles and behaviours intended to prevent cervical cancer. Cochrane Database Syst Rev 2000;2:CD001035.

72. Winer RL, Hughes JP, Feng Q, O’Reiley S, Kiviat NB, Holmes KK, Koutsky LA. Condom use and the risk of genital human papillomavirus infection in young women. N Engl J Med 2006;354:2645-54.

73. Harro CD, Pang YY, Roden RB, Hildesheim A, Wang Z, Reynolds MJ, Mast TC, Robinson R, Murphy BR, Karron RA, Dillner J, Schiller JT, Lowy DR. Safety and immunogenicity trial in adult volunteers of a human papillomavirus 16 L1 virus-like particle vaccine. J Natl Cancer Inst 2001;93:284-92. 
74. Paavonen J, Jenkins D, Bosch FX, Naud P, Salmerón J, Wheeler CM, Chow SN, Apter DL, Kitchener HC, Castellsague X, de Carvalho NS, Skinner SR, Harper DM, Hedrick JA, Jaisamrarn U, Limson GA, Dionne M, Quint W, Spiessens B, Peeters P, Struyf F, Wieting SL, Lehtinen MO, Dubin G; HPV PATRICIA study group. Efficacy of a prophylactic adjuvanted bivalent L1 virus-like-particle vaccine against infection with human papillomavirus types 16 and 18 in young women; an interim analysis of a phase III double-blind, randomised controlled trial. Lancet 2007;369:2161-70.

75. Schiffman M, Castle PE, Jeronimo J, Rodriguez AC, Wacholder S. Human papillomavirus and cervical cancer. Lancet 2007;370:890-907.

76. Pett $M$, Coleman N. Integration of high-risk human papillomavirus: a key event in cervical carcinogenesis? J Pathol 2007;212:356-67.

77. Dowhanick JJ, McBride AA, Howley PM. Suppression of cellular proliferation by the papillomavirus E2 protein. J Virol 1995;69:7791-9.

78. van den Akker EH, Hoes AW, Burton MJ, Schilder AG. Large international differences in (adeno) tonsilectomy rates. Clin Otolaryngol Allied Sci 2004;29:161-4.

79. Al-Sarraf M. Treatment of locally advanced head and neck cancer: historical and critical review. Cancer Control 2002;9:387-99.

80. Lindel K, Beer KT, Laissue J, Greiner RH, Aebersold DM. Human papillomavirus positive squamous cell carcinoma of the oropharynx: a radiosensitive subgroup of head and neck carcinoma. Cancer 2001;92:805-13.

81. Worden FP, Kumar B, Lee JS, Wolf GT, Cordell KG, Taylor JMG, Urba SG, Eisbruch A, Teknos TN, Chepeha DB, Prince ME, Tsien CI, D’Silva NJ, Yang K, Kurnit DM, Mason HL, Miller TH, Wallace NE, Bradford $\mathrm{CR}$, Carey TE. Chemoselection as a strategy for organ preservation in advanced oropharynx cancer: response and survival positively associated with HPV16 copy number. J Clin Oncol 2008;26:3138-46.

82. Abdulkarim B, Bourhis J. Antiviral approaches for cancers related to Epstein-Barr virus and human papillomavirus. Lancet Oncol 2001;2:622-30.

83. Abdulkarim B, Sabri S, Deutsch E, Chagraoui H, Maggiorella L, Thierry J, Eschwege F, Vainchenker W, Chouaïb S, Bourhis J. Antiviral agent Cidofovir restores p53 function and enhances the radiosensitivity in HPV-associated cancers. Oncogene 2002;21:2334-46.

84. Sirianni N, Wang J, Terris RL. Antiviral activity of Cidofovir on a naturally human papillomavirus16 infected squamous cell carcinoma of the head and neck (SCCHN) cell line improves radiation sensitivity. Oral Oncol 2005;41:423-8.

85. Snoeck R, Andrei G, De Clercq E. Cidofovir in the treatment of HPV-associated lesions. Verh K Acad Geneeskd Belg 2001;63:93-120.

86. Modjtahedi H. Molecular therapy of head and neck cancer. Cancer Metastasis Rev 2005;24:129-46.

87. Vokes EE, Chu E. Anti-EGFR therapies: clinical experience in colorectal, lung, and head and neck cancers. Oncology 2006;20:15-25.

88. Barnes CJ, Ohshiro K, Rayala SK, El-Naggar AK, Kumar R. Insulin-like growth factor receptor as a therapeutic target in head and neck cancer. Clin Cancer Res 2007;13:4291-9.

89. Altieri DC. Targeted therapy by disabling crossroad signalling networks: the survivin paradigm. Mol Cancer Ther 2006;3:478-82.

90. Tang X, Zhang Q, Nishitani J, Brown J, Shi S, Le AD. Overexpression of human papillomavirus type 16 oncoproteins enhances hypoxia-inducible factor 1 -alpha protein accumulation and vascular endothelial growth factor expression in human cervical carcinoma cells. Clin Cancer Res 2007;13:2568-76.

91. Putral LS, Bywater MJ, Gu W, Saunders NS, Gabrielli BG, Leggatt GR, McMillan NAJ. RNA interference against human papillomavirus oncogenes in cervical cancer cells results in increased sensitivity to cisplatin. Mol Pharmacol 2005;68:1311-9.

92. Shillitoe EJ. Papillomaviruses as targets for cancer gene therapy. Cancer Gene Ther 2006;12:44550 .

93. Sima N, Wang W, Kong D, Deng D, Xu Q, Zhou J, Xu G, Meng L, Lu Y, Wang S, Ma D. RNA interference against HPV16 E7 oncogene leads to viral E6 and E7 suppression in cervical cancer cells and apoptosis via upregulation of Rb and p53. Apoptosis 2008;13:273-81. 


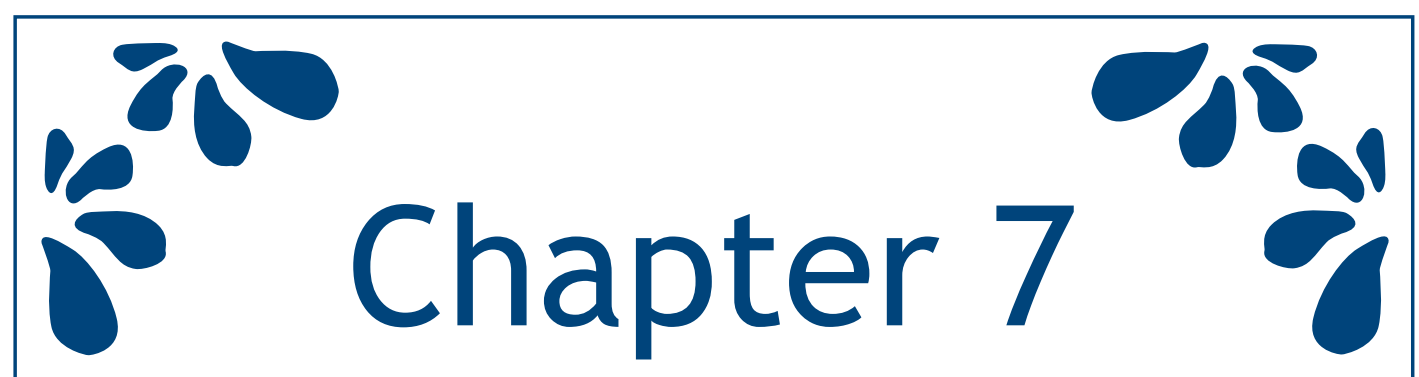

Summary
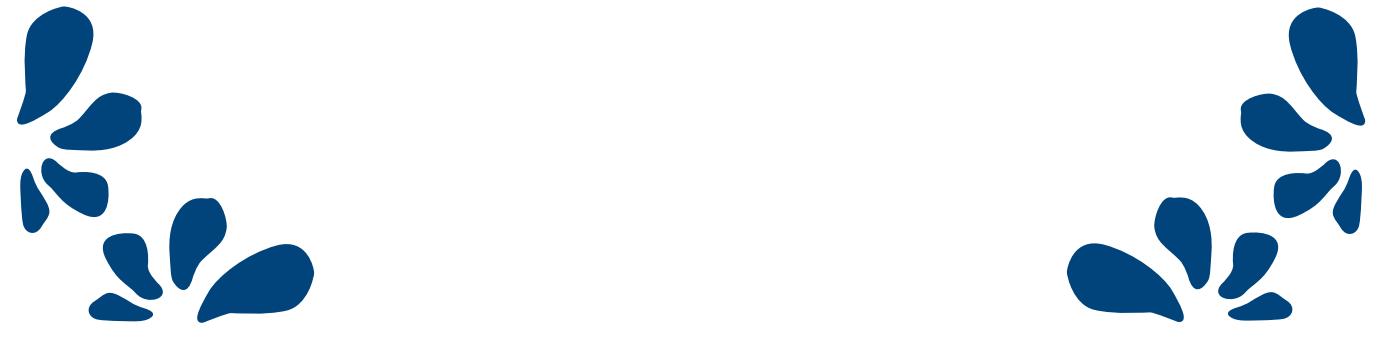
Chapter 1 reviews epidemiological aspects and risk factors of head and neck cancer. Head and neck cancer represents $6,5 \%$ of all annual cancer cases worldwide. This incidence is increasing in Western Europe and the US during the last decades. Besides the well known risk factors such as smoking, extensive alcohol use and betel quid chewing it has become clear that also oncogenic human papilloma viruses (HPVs) may play a role in the carcinogenesis of head and neck cancer. An overview of the HPVs is provided as well as an overview of the oncogenes that are expressed when the viral DNA is integrated in the host cell genome.

The overall aim of this thesis was to obtain more insight into the role of HPVs in the tumorigenesis of head and neck cancer, and into the clinical effects of HPV infection.

Oncogenic HPVs cause cancer by inactivation of the cell cycle regulators p53 and pRb by expression of viral oncoproteins E6 and E7. This means that p53 mutations are not a prerequisite in HPV-induced tumor development. However, a discrepancy existed in the literature with respect to the percentage of head and neck squamous cell carcinomas (HNSCC) harboring oncogenic HPV and the fraction of these tumors showing p53 mutations. The different results may be due to the detection method used, the anatomic location of tumors, the type of HPV detected and/or the number of tissue samples analyzed in the various studies. Because HNSCC are thought to arise via a multistep process with histologically distinct precursor phenotypes the relationship between the presence of HPV16/18 and p53 alterations in premalignant lesions of the head an neck mucosa, HNSCC and their metastases was examined. This study is presented in Chapter 2. For the detection of HPV the fluorescence in situ hybridization (FISH) protocol, combined with tyramide signal amplification was applied to paraffin-embedded tissue sections. Clinical data, as well as alcohol and tobacco intake were related to the presence of HPV in the tumors. It was found that HPV $16 / 18$ DNA could not be detected in the premalignant lesions. Ten of the 47 HNSCC exhibited HPV 16-specific FISH signals and only in one case a simultaneous infection with HPV 18 was observed. Of these 10 HPV positive HNSCC, 9 were derived from the oropharynx, indicating a highly significant correlation between HPV positivity and localization in the oropharynx and especially in the tonsils. From the patients of which lymph node metastases were available for analysis, both the metastasis as well as the primary tumor displayed identical punctate nuclear HPV FISH signals, indicating stable integration of the virus prior to and during tumor 
metastasis. Interestingly, $64 \%$ of the HNSCC showed accumulation of p53, including 8 of the $10 \mathrm{HPV}$ positive carcinomas. In the HPV positive carcinomas with p53 overexpression, p53 mutations in exon 5-8 could not be detected, suggesting an overexpression of the wild-type p53. This study also showed a significant correlation between on the one hand low or absent exposure to tobacco and alcohol and HPV integration on the other.

Since it became known that oncogenic HPVs are of importance in the pathogenesis of HNSCC and especially oropharyngeal carcinomas, 81 tonsillar squamous cell carcinomas (TSCC) were examined for the presence of HPV 16, as described in Chapter 3. Integration of oncogenic HPV DNA into the human cellular genome is considered an important step in malignant transformation. After integration and disruption of (part of) the viral E2 gene, an upregulation of the oncoproteins E6 and E7 is detected. The HPV E6 protein can interact with the cellular wildtype p53 tumor suppressor protein, inducing p53 degradation via the ubiquitinmediated pathway. The E7 protein inactivates pRb, resulting in release of the transcription factor E2F and upregulation of $\mathrm{p} 14^{\mathrm{ARF}}$ and $\mathrm{p} 16^{\mathrm{INK} 4 \mathrm{~A}}$. With respect to viral integration in oropharyngeal cancers however, the literature is controversial. In this study we used the FISH method for the detection of HPV 16 . This technique allows the visualization of 1 copy of HPV DNA in tumor cells and at the same time the determination of the physical status (integrated versus episomal) of the virus on basis of the nuclear staining pattern. Furthermore, it was examined if p16 $16^{\text {NKKA }}$ overexpression as detected by immunohistochemistry correlates with HPV 16 positivity, in order to investigate whether or not this method can reliably distinguish between HPV-positive and HPV-negative TSCC. The results were correlated to clinical and demographic data. HPV 16 DNA integration was detected in $41 \%$ of the TSCC. All but one of the $33 \mathrm{HPV}$-positive tumors, and only 5 out of $48 \mathrm{HPV}$-negative tumors showed overexpression of $\mathrm{p} 16^{\mathrm{INK} 4 \mathrm{~A}}$. This implicates that $\mathrm{p} 16^{\mathrm{INK} 4 \mathrm{~A}}$ overexpression may be considered a reliable HPV biomarker. The presence of HPV furthermore correlated significantly with low tobacco and alcohol intake, poor differentiation grade, small tumor size, presence of a local metastases and a decreased (loco) regional recurrence rate. Statistical analysis showed that patients with HPV- positive tumors had a statistically better overall and disease specific survival rate. The 5 years disease-specific survival for patients with HPV-positive and HPV-negative carcinomas was $55 \%$ and $29 \%$, respectively. Apart from absence of HPV 16, also lack 
of $\mathrm{p} 16^{\text {INK4A }}$ overexpression, smoking, a combination of smoking and alcohol abuse, a tumor diameter of $>4 \mathrm{~cm}$ and development of recurrent disease were associated with a shorter disease-specific survival in patients with TSCC. Multivariate analysis of all data, however, revealed that tobacco smoking was the strongest prognostic indicator. Smokers had a 5.5 times higher chance of cancer death compared to nonsmokers, and patients with HPV-negative TSCCs were found to exhibit a 2 times higher chance of cancer death compared to patients with HPV-positive tumors. These data indicate that oncogenic processes in the tonsils of non-smokers differ from those in smokers, the former being related to HPV 16 infection.

Since $\mathrm{p} 16^{\text {INK4A }}$ overexpression has been proposed as a potential biomarker for infection with HPV in squamous cell carcinomas it was investigated if $\mathrm{p} 16^{\text {INK4A }}$ overexpression could also predict the presence of HPV in tumor-free tonsillar tissue. For this purpose paraffin-embedded tumor-free tonsils of 262 patients were tested for $\mathrm{p} 16^{\mathrm{INK} 4 \mathrm{~A}}$ overexpression by immunohistochemistry and HPV presence was tested by HPV-specific PCR analysis and FISH. In Chapter 4 a detailed prescription of this study is given. P16 ${ }^{\mathrm{INK} 4 \mathrm{~A}}$ overexpression was found in $28 \%$ of the tissue samples, whereas HPV DNA could not be detected by PCR and FISH analysis. Therefore it is concluded that $\mathrm{p} 16^{\mathrm{INK} 4 \mathrm{~A}}$ overexpression is not a suitable marker to predict the presence of HPV in tumor-free tonsils. Other mechanisms than HPV infection seem therefore also to be implicated in upregulation of p16 $16^{\text {INK4A }}$.

In Chapter 5 the expression of key cell cycle proteins in the pRb en p53 pathways was examined in a series of $77 \mathrm{TSCC}$, with the goal to determine their role in HPVdependent and HPV-independent carcinogenesis. Furthermore, their prognostic value was evaluated by correlating the results with clinical follow-up data. Is was shown that HPV16-positive tumors exhibit p14ARF and p21 Cip1/WAF1 overexpression, next to downregulation of $\mathrm{pRb}$ and cyclin D1, which was not found in HPV16-negative tumors. Statistical analysis revealed a favorable survival rate for non-smokers, as well as for patients with T1-2 tumors or tumors showing low expression of cyclin $\mathrm{D} 1$, presence of HPV and overexpression of $\mathrm{p} 16^{\mathrm{INK} 4 \mathrm{~A}}$, p14 ARF or p21 $1^{\mathrm{Cip} 1 / \text { WAF1 }}$. In multivariate regression analyses smoking and tumor size, as well as expression of cyclin D1 and p21 Cip1/WAF1 were found to be independent prognostic markers. In particular p21 $1^{\text {Cip } 1 / \text { WAF1 }}$ overexpression appeared to be the strongest indicator for a favorable outcome in patients with TSCC. 
Finally, in Chapter 6 an overall discussion of the results is presented and findings are related to the recent literature. On basis of the results described in this thesis a diagnostic sequence for routine practice is suggested and treatment protocols are proposed. 


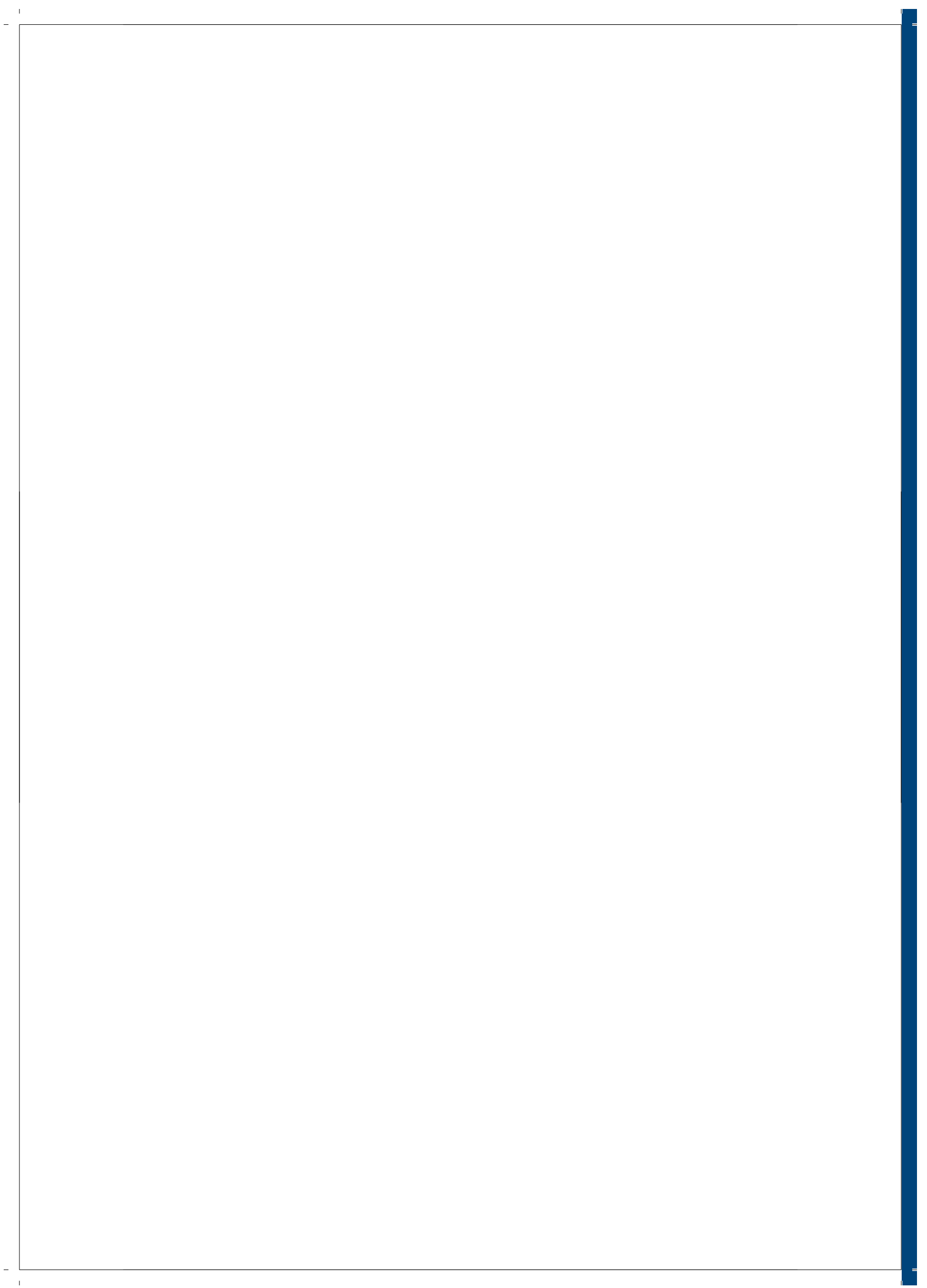



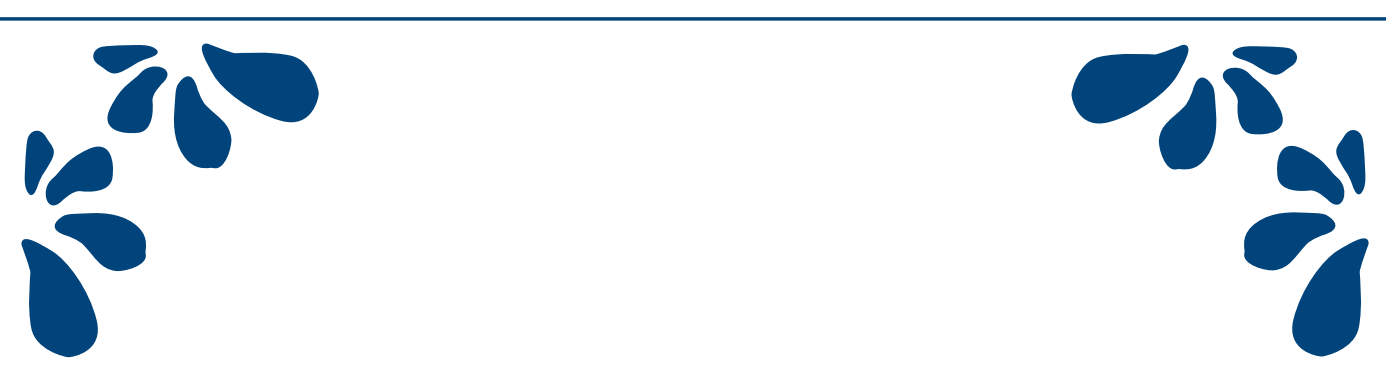

Samenvatting
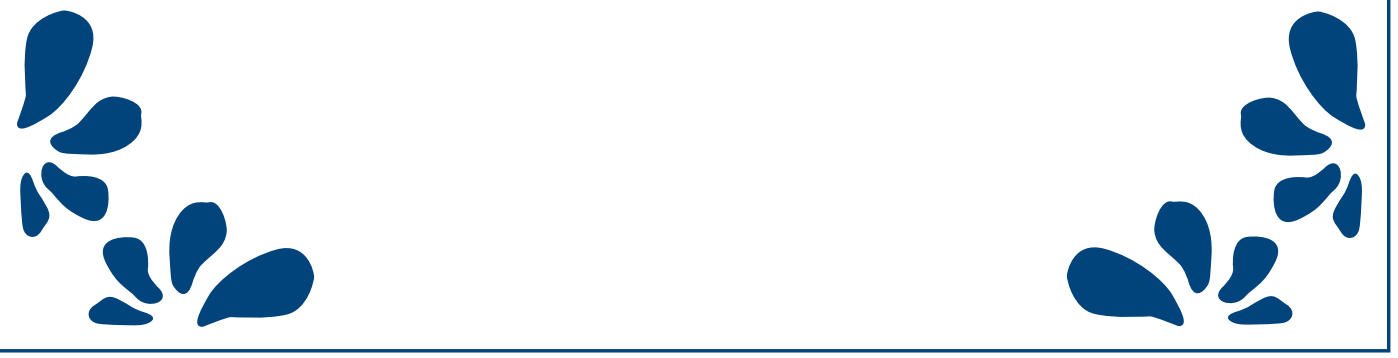
In Hoofdstuk 1 wordt een overzicht gegeven van de epidemiologische aspecten van hoofd- halskanker en tevens wordt ingegaan op de risicofactoren die kunnen lijden tot het ontstaan van hoofd-halskanker. Hoofd-halskanker vertegenwoordigd $6,5 \%$ van alle nieuwe kankergevallen wereldwijd. Deze incidentie neemt de laatste jaren toe in West Europa en de Verenigde Staten. Naast de bekende risicofactoren zoals roken, overmatig alcoholgebruik en het kauwen van betelnoten is het duidelijk geworden dat ook oncogene humaan papilloma virussen (HPVs) een rol kunnen spelen bij het ontstaan van hoofd-halskanker. Er wordt een overzicht gegeven van het HPV, evenals van de oncogenen die tot expressie kunnen komen wanneer het virale DNA in het genoom van de gastheer integreert. Het doel van dit promotie-onderzoek was meer inzicht te verkrijgen in de rol die het HPV speelt bij het tot stand komen van hoofdhalskanker.

De oncogene HPVs veroorzaken kanker ten gevolge van inactivatie van de celcyclus regulerende eiwitten p53 en pRb door middel van de virale oncogene eiwitten E6 en E7. Dit betekent dat p53 mutaties niet noodzakelijk zijn bij HPV-geïnduceerde tumorontwikkeling. Met betrekking tot het percentage hoofd-halstumoren dat oncogeen HPV bevat en tegelijk mutaties heeft in het p53 eiwit bestaat echter onduidelijkheid in de literatuur. Deze onduidelijkheid wordt mogelijk veroorzaakt door het gebruik van verschillende detectie methoden, de anatomische locatie van de tumor, het type HPV en/of het aantal tumoren dat onderzocht werd in de verschillende onderzoeken. Aangezien de ontwikkeling van hoofd-halstumoren verloopt via meerdere stappen met histologisch te onderscheiden voorloper stadia werd getracht de relatie tussen de aanwezigheid van HPV type 16 en 18 enerzijds en p53 veranderingen anderzijds in voorloperleasies van de hoofd-hals mucosa, in hoofd- halscarcinomen en in hun metastasen vast te stellen. Dit onderzoek wordt beschreven in Hoofdstuk 2. Voor de detectie van HPV in paraffine coupes werd de fluorescente in situ hybridisatie (FISH) techniek gecombineerd met tyramide signaal versterking. De aanwezigheid van HPV in de tumoren werd gecorreleerd aan klinische gegevens en gegevens over het drink- en rookgedrag. In de premaligne laesies die werden onderzocht kon geen HPV 16/18 DNA gedetecteerd worden. In 10 van de 47 hoofd-halscarcinomen werd een HPV 16 specifiek FISH signaal gevonden en slechts in één geval werd tegelijkertijd een infectie met HPV 18 waargenomen. Van deze $10 \mathrm{HPV}$-positieve hoofd-halscarcinomen bleken er 9 afkomstig uit de oropharynx, hetgeen betekent dat er een duidelijk significante correlatie is tussen 
HPV positiviteit en lokalisatie in de oropharynx en met name in de tonsillen. Bij de patiënten waarbij zowel de primaire tumor en de lymfeklier-metastase werd onderzocht, bleek dat zowel de tumor als de metastase hetzelfde nucleaire HPVsignaal toonden. Dit betekent dat het virus stabiel in het genoom is geïntegreerd alvorens de tumor zich verspreidt. In $64 \%$ van de hoofd- halscarcinomen, waaronder 8 van de $10 \mathrm{HPV}$-positieve carcinomen, werd een stapeling van p53 gevonden. In de $\mathrm{HPV}$-positieve carcinomen met p53 overexpressie werden geen mutaties gevonden in exon 5-8 van p53, hetgeen suggereert dat er een overexpressie is van het wild-type p53. Gegevens uit dit onderzoek toonden eveneens een significante correlatie tussen HPV-integratie en een beperkt gebruik van alcohol en tabak.

Aangezien de oncogene HPVs een rol spelen bij het ontstaan van hoofd-halscarcinomen, met name in oropharyngeale carcinomen, werden 81 tonsilcarcinomen onderzocht op de aanwezigheid van HPV16. Dit onderzoek wordt beschreven in Hoofdstuk 3. Integratie van het oncogene HPV DNA in het menselijke cellulaire genoom wordt als een belangrijke stap in de maligne transformatie beschouwd. Na integratie en verstoring van (een gedeelte van) het virale E2 eiwit wordt er een verhoogde hoeveelheid van de oncogene eiwitten E6 en E7 gedetecteerd. Het HPV E6 eiwit kan een verbinding aangaan met p53, waardoor dit eiwit wordt afgebroken. Het E7 eiwit inactiveert het pRb, waardoor de transcriptie-factor E2F vrijkomt en er een verhoogde expressie van p14ARF en p16 $6^{\mathrm{INK} 4 \mathrm{~A}}$ wordt gezien. Met betrekking tot de virale integratie bij oropharyngeale carcinomen bestaan tegenstrijdige berichten in de literatuur. In deze studie is de FISH-methode gebruikt voor het aantonen van HPV 16. Deze techniek maakt het mogelijk om slechts 1 kopie van het HPV DNA in de tumorcellen in beeld te brengen en tegelijkertijd is het mogelijk om te bepalen wat de fysieke toestand van het virus is (geïntegreerd ten opzichte van episomaal), dit op basis van het kleuringspatroon in de celkernen. Daarnaast werd onderzocht of p16 INK4A overexpressie, zoals aangetoond met behulp van immunocytochemie, correleert met HPV 16 positiviteit, met als doel te onderzoeken of deze detectiemethode betrouwbaar is om een onderscheid te maken tussen HPVpositieve en HPV-negatieve tonsilcarcinomen. De resultaten werden gecorreleerd aan klinische en epidemiologische gegevens. HPV 16 integratie werd gedetecteerd in $41 \%$ van de tonsilcarcinomen. Alle behalve één van de $33 \mathrm{HPV}$-positieve tumoren en slechts 5 van de $48 \mathrm{HPV}$-negatieve tumoren toonden overexpressie van p16 ${ }^{\mathrm{INK} 4 \mathrm{~A}}$. Dit impliceert dat $\mathrm{p} 16^{\mathrm{INK} 4 \mathrm{~A}}$ overexpressie gezien kan worden als een betrouwbare 
biomarker voor de aanwezigheid van HPV. Deze aanwezigheid van HPV correleerde verder significant met een laag alcohol- en tabakgebruik, een slechtere differentiatie, kleinere tumor diameter, de aanwezigheid van locale metastasen en een verlaagde kans op terugkeer van de tumoren. Statistische analyse van de gegevens toonde aan dat patiënten met HPV-positieve tumoren een betere ziekte-specifieke en totale overlevingskans hebben. De 5-jaars ziekte-specifieke overleving voor patiënten met HPV-positieve en HPV-negatieve carcinomen bedroeg respectievelijk $55 \%$ en $29 \%$. Naast afwezigheid van HPV 16 bleek ook afwezigheid van p16 1NK4A overexpressie, roken, een combinatie van roken en alcohol gebruik, een tumor diameter van meer dan $4 \mathrm{~cm}$ en de ontwikkeling van terugkerende ziekte geassocieerd met een kortere ziekte-specifieke overleving bij patiënten met tonsilcarcinomen. Multivariantie analyse van alle gegevens toonde echter aan dat roken de belangrijkste prognostische factor was. Rokers hadden een 5,5 keer grotere kans om aan kanker te overlijden dan niet-rokers. Patiënten met HPV-negatieve tonsilcarcinomen bleken 2 keer zoveel kans te hebben om aan kanker te overlijden dan patiënten met HPV-positieve tonsiltumoren. Deze gegevens tonen aan dat de oncogene processen in de tonsil bij niet-rokers verschillen van het proces bij rokers, waarbij het proces bij de nietrokers gecorreleerd is aan HPV 16 infecties.

Aangezien p16 ${ }^{1 \mathrm{NK} 4 \mathrm{~A}}$ overexpressie gezien kon worden als marker voor de aanwezigheid van HPV in carcinomen, werd onderzocht of $\mathrm{p} 16^{\mathrm{INK} 4 \mathrm{~A}}$ overexpressie ook de aanwezigheid van HPV in tumorvrij tonsilweefsel kon voorspellen. Met dit doel werden tumorvrije tonsillen onderzocht van 262 patiënten. De aanwezigheid van p16 ${ }^{\mathrm{INK} 4 \mathrm{~A}}$ overexpressie werd bekeken met behulp van immunocytochemie. De aanwezigheid van HPV werd getest met behulp van HPV-specifieke PCR analyse en FISH. In Hoofdstuk 4 wordt een gedetailleerde beschrijving van deze studie gegeven. P16 ${ }^{\text {INK4A }}$ overexpressie werd gevonden in $28 \%$ van de tumorvrije tonsillen en HPV kon met behulp van PCR analyse worden aangetoond in 2 tonsillen, terwijl FISH deze aanwezigheid van HPV niet kon bevestigen. Uit deze gegevens werd dan ook geconcludeerd dat p16 ${ }^{\text {INK } 4 \mathrm{~A}}$ overexpressie geen betrouwbare marker is om de aanwezigheid van HPV te voorspellen in tumorvrije tonsillen. Andere mechanismen dan HPV infecties moeten daarom verantwoordelijk zijn voor deze $\mathrm{p} 16^{\mathrm{INK} 4 \mathrm{~A}}$ overexpressie.

In Hoofdstuk 5 wordt het onderzoek beschreven naar de expressie van verschillende celcyclus-eiwitten in de PRB- en p53-routes van een serie van 77 tonsilcarcinomen. 


$$
1
$$




\section{Dankwoord}

Het onderzoek beschreven in dit proefschrift is tot stand gekomen door een samenwerking van de vakgroep KNO-heelkunde van het academisch ziekenhuis Maastricht en de afdeling Moleculaire Celbiologie van de universiteit van Maastricht. Mijn dank gaat uit naar de vele mensen van deze afdelingen die hieraan een bijdrage hebben geleverd. Een aantal van hen wil ik in het bijzonder bedanken. Allereerst wil ik mijn beide promotores, Hans Manni en Frans Ramaekers, en mijn co-promotor, Ernst-Jan Speel, bedanken voor hun ondersteuning.

Prof Manni, beste Hans, in mijn ogen ben jij de opleider en promotor zoals een ieder zich zou wensen. Dankzij jou heb ik de kans gekregen de opleiding tot KNO-arts in Maastricht te volgen. Jouw enorme enthousiasme voor het werk en de wetenschap heeft mij erg gemotiveerd. Jij wist me te activeren en stimuleren op momenten dat mijn motivatie minder was, zonder deze drijfkracht had dit boekje nu niet voor ons gelegen. Daarnaast leef je ook al jaren mee met het wel en wee in mijn persoonlijke leven, je attente kaartjes en telefoontjes waardeer ik altijd erg.

Prof Ramaekers, beste Frans, tijdens de vele jaren dat het onderzoek heeft gelopen hebben we vrij weinig contact gehad. Vanaf de zijlijn stuurde en observeerde je de voortgang en op de cruciale momenten had je zeer waardevolle adviezen en verbeter plannen. Mede dankzij jouw kopieer en inbindkunst hebben we deze datum gehaald.

Dr Speel, beste Ernst-Jan, altijd erg druk bezet en toch heb je tussendoor de tijd gevonden om dit onderzoek draaiende te houden. Jouw nauwkeurigheid deed mij soms wanhopen, maar daardoor heeft het boekje wel de diepgang gekregen die het nu heeft. Heel erg bedankt voor al het werk wat je voor dit onderzoek hebt gedaan!

Dr Bot, beste Freek, vanuit de pathologie was je met name in de beginfase nauw betrokken bij het onderzoek. De uren dat we samen achter de microscoop hebben gezeten om histologische coupes te classificeren heb ik altijd erg gewaardeerd.

Annick en Sandra, bedankt voor alle adviezen en hulp bij de immunohistochemische kleuringen en het snijden van de coupes en natuurlijk ook voor al het werk wat jullie voor dit onderzoek hebben gedaan. 
Marcel Schepers, Boris Klingenberg en Jeroen Mooren bedankt voor de kleuringen, het denk- en schrijfwerk wat jullie voor dit onderzoek hebben verricht.

De leden van de manuscriptcommissie en de leden van de promotiecommissie wil ik hartelijk bedanken voor hun beoordeling en aanwezigheid.

Alle collega stafleden, arts-assistenten, onderzoekers en medewerkers van de afdeling KNO uit het AZM wil ik bedanken voor hun interesse, adviezen en gezellige sfeer waarin ik jarenlang heb kunnen werken. Het is een erg fijne tijd geweest om met plezier aan terug te denken.

Intussen maak ik nu bijna 5 jaar deel uit van de maatschap KNO van het Reinier de Graafgasthuis te Delft. Ik krijg daar de kans om de kennis en kunde die ik heb opgedaan in praktijk te brengen en te ontwikkelen. Ik zie uit naar een langdurige collegiale samenwerking.

Lieve vrienden en familie, jullie wil ik bedanken voor jullie interesse, geduld en steun tijdens het schrijven van dit proefschrift, maar vooral ook daarbuiten. Jullie zijn het die het leven kleur geven!

Karola en Marieke, mijn paranimfen, tijdens onze studietijd hebben we bewezen goed en vooral erg gestructureerd te kunnen samenwerken. Zonder jullie was het me nooit gelukt de studies Biomedische Wetenschappen en Geneeskunde af te ronden en had ik hier nu niet gestaan. Door de afstand, ons werk en gezin zien we elkaar minder, maar de vriendschap is gebleven. Bedankt dat jullie mijn paranimfen willen zijn.

Lieve papa en mama, jullie wil ik bedanken voor jullie medeleven bij alles wat belangrijk is in mijn leven. Jullie hebben me altijd gestimuleerd om verder te leren en ergens voor te gaan. Ik kan altijd een beroep op jullie doen en jullie staan altijd voor me klaar. Mijn proefschrift is aan jullie opgedragen. Dat zegt alles!

Roland, je wilde niet dat ik je zou bedanken voor je bijdrage aan dit "opstel". Toch wil ik je bedanken omdat jij mijn leven meer inhoud hebt gegeven en dat jij er voor me bent in goede en in slechte dagen. Samen hebben we een geweldige zoon, onze lieve Hugo. Nu mijn promotie is afgerond zal ik meer tijd hebben om met jullie en onze dochter of zoon in wording door te brengen. 


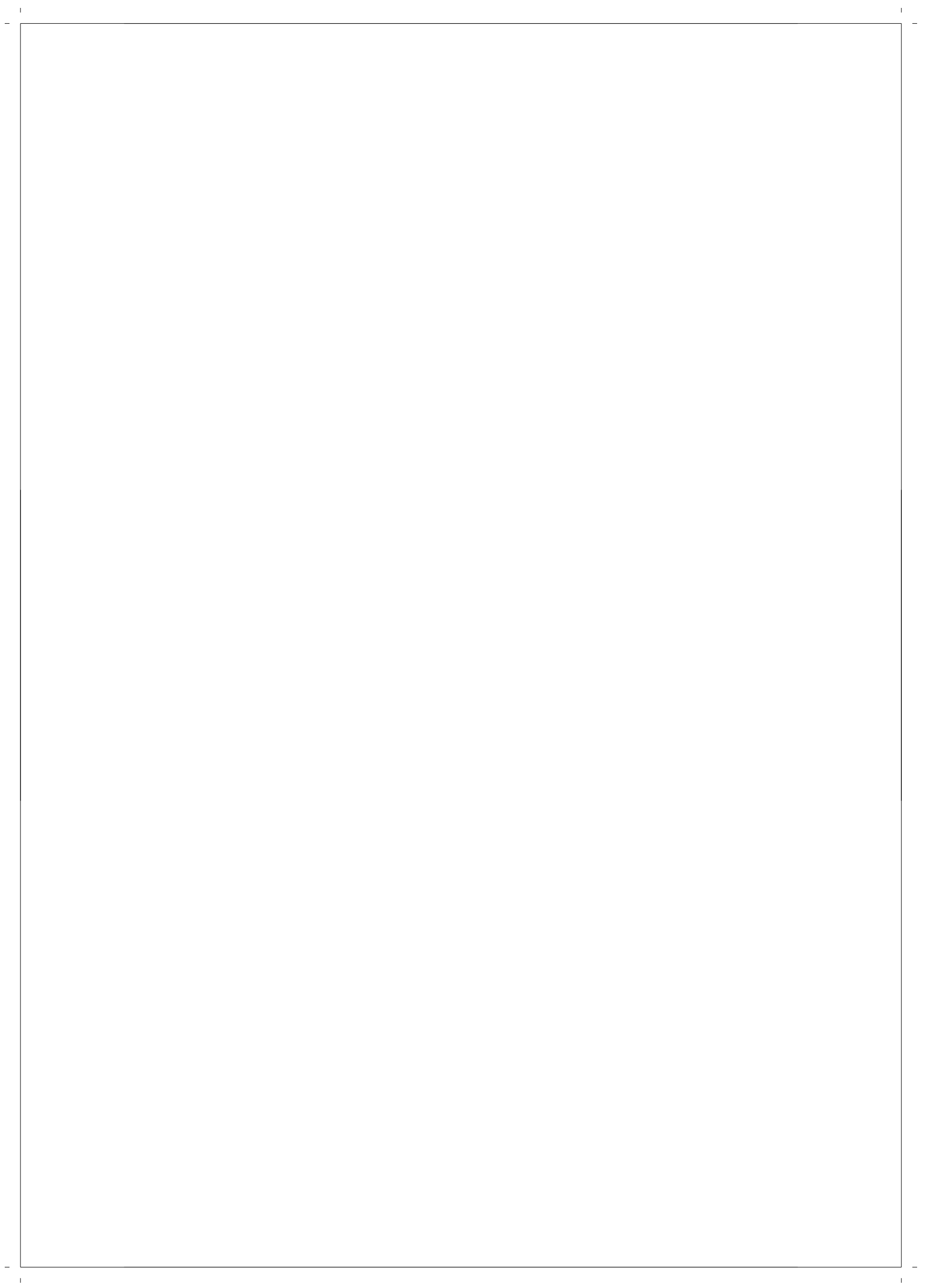




\section{Curriculum Vitae}

Harriët Hafkamp, auteur van dit proefschrift, werd op 10 juni 1971 geboren te Hilversum. Met haar oudere zus Martine groeide zij op in het ouderlijk gezin te Kortenhoef. In 1989 behaalde zij haar V.W.O. diploma aan het Comenius College te Hilversum. Datzelfde jaar startte zij met de studie Biomedische Wetenschappen aan de Rijksuniversiteit Leiden. In 1991 startte zij tevens met de studie Geneeskunde eveneens aan de Rijksuniversiteit Leiden. De opleiding Biomedische Wetenschappen werd afgesloten met onderzoek naar de seroprevalentie van Strongyloides Stercoralis aan de Anton de Kom Universiteit van Paramaribo, Suriname onder begeleiding van Prof. Dr. A.M. Polderman en Prof. Dr. B.F.J. Oeseburg. In 1997 werden beide studies afgerond en begon zij als AGNIO te werken op de afdeling KNO van het Academisch Ziekenhuis Maastricht. In dit jaar begon zij met het onderzoek dat heeft geleid tot deze dissertatie. Van april 1998 tot april 2003 werd zij opgeleid tot Keel-, Neus-, en Oorarts in het Academisch Ziekenhuis Maastricht, onder leiding van Prof. Dr. J.J. Manni. De B-opleiding werd gevolgd in het Atrium Medisch Centrum te Heerlen, onder leiding van Dr. T.D. Zijlker. Na het afronden van de opleiding bleef zij werkzaam als staflid KNO in het Academisch Ziekenhuis Maastricht. Sinds september 2004 is de auteur toegetreden tot de KNO maatschap van het Reinier de Graaf gasthuis te Delft. De auteur woont samen met Roland Hage en samen hebben zij een prachtige zoon, Hugo (2007). 


\section{List of publications}

Hafkamp HC, Bruintjes TD, Huizing EH. Functional anatomy of the premaxillary area. Rhinology 1999;37:21-4.

Hafkamp HC, Speel EJM, Haesevoets A, Bot FJ, Dinjens WNM, Ramaekers FCS, Hopman AHN, Manni JJ. A subset of head and neck squamous cell carcinomas exhibits integration of HPV 16/18 DNA and overexpression of p16 ${ }^{\text {INK4A }}$ and p53 in the absence of mutations in p53 exons 5-8. Int J Cancer 2003;107:394-400.

Hafkamp HC, Van der Goten A, Manni JJ. Unilateral spontaneous dissection of the internal carotid artery presenting as hypoglossal nerve palsy. Eur Arch Otorhinolaryngol 2004;261:405-8.

Hafkamp HC, Manni JJ, Speel EJ. Role of human papillomavirus in the development of head and neck squamous cell carcinomas. Acta Otolaryngol 2004;124:520-6.

Hafkamp HC, Manni JJ, Haesevoets A, Voogd AC, Schepers M, Bot FJ, Hopman AHN, Ramaekers FCS, Speel EJM. Marked differences in survival rate between smokers and non-smokers with HPV 16-associated tonsillar carcinomas. Int J Cancer 2008;122:2656-64. 


\section{List of abbreviations}

$A B C$

APOT

Cdk

$\mathrm{Cl}$

CT

DAPI

EDTA

EGFR

FISH

HNSCC

HPV

HR

IGF-1R

ISH

NA

NS

OR

PBS

PCR

RT

SD

SSC

SSCP

TSA

TSCC

UPT avidin-biotinylated peroxidase complex

amplification of papillomavirus oncogene transcripts

cyclin-dependent kinase

confidence interval

chemotherapy

6-diamidino-2-phenyl indole

ethylene diamine tetra-acetic acid

epidermal growth factor receptor

fluorescence in situ hybridisation

head and neck squamous cell carcinoma

human papillomavirus

hazard ratio

insulin-like growth factor type 1 receptor

in situ hybridization

not available

not significant

odds ratio

phosphate buffered saline

polymerase chain reaction

radiation therapy

standard deviation

saline sodium citrate

single-strand conformation polymorphism

tyramide signal amplification

tonsil squamous cell carcinoma

unknown primary tumor 


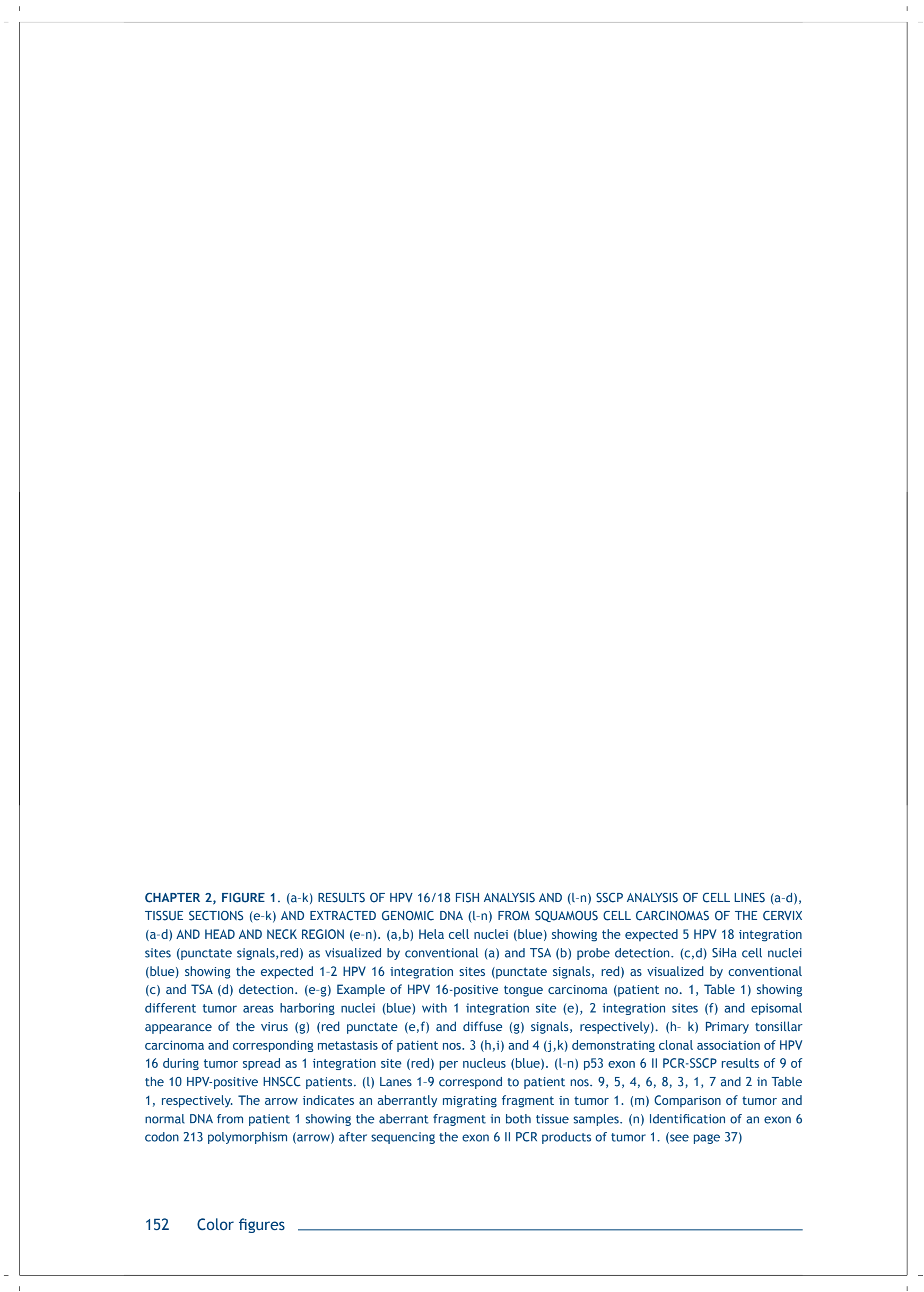




$$
1
$$




$$
\mid
$$


CHAPTER 3, FIGURE 1. REPRESENTATIVE EXAMPLES OF HPV 16 FISHANALYSIS (A, B) AND P16INK4A IMMUNOSTAINING (C, D) ON PARAFFIN-EMBEDDED TISSUE SECTIONS OF TSCC. (A) Example of one HPV 16-specific punctate signal per nucleus (red) indicating viral integration. Tumor cell nuclei are blue due to DAPI staining (B) Example of a tumor area showing diffuse nuclear staining (red) indicating viral replication (episomal virus copies), nuclei are DAPI counterstained. (C-D) Overexpression of p16 $16^{\mathrm{INK} 4 \mathrm{~A}}$ (brown peroxidase-diamino benzidine staining) in two HPV 16-positive TSCC, nuclei counterstained by hematoxylin (purpel). (see page 59) 


$$
1
$$




$$
1
$$



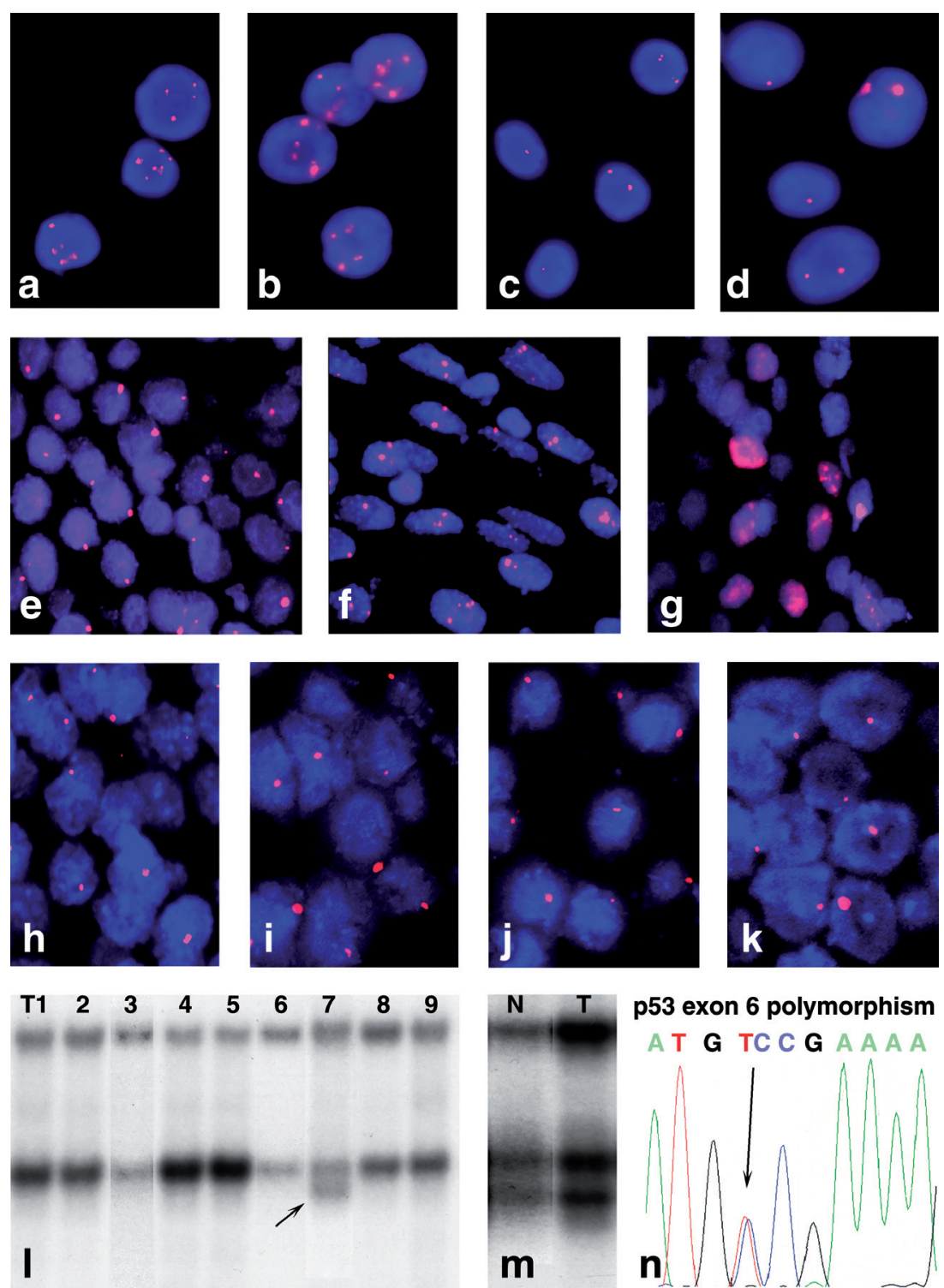

I

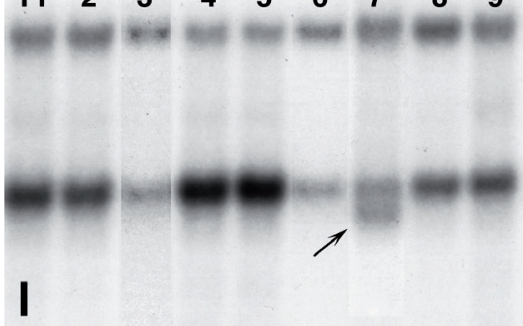

m

n 

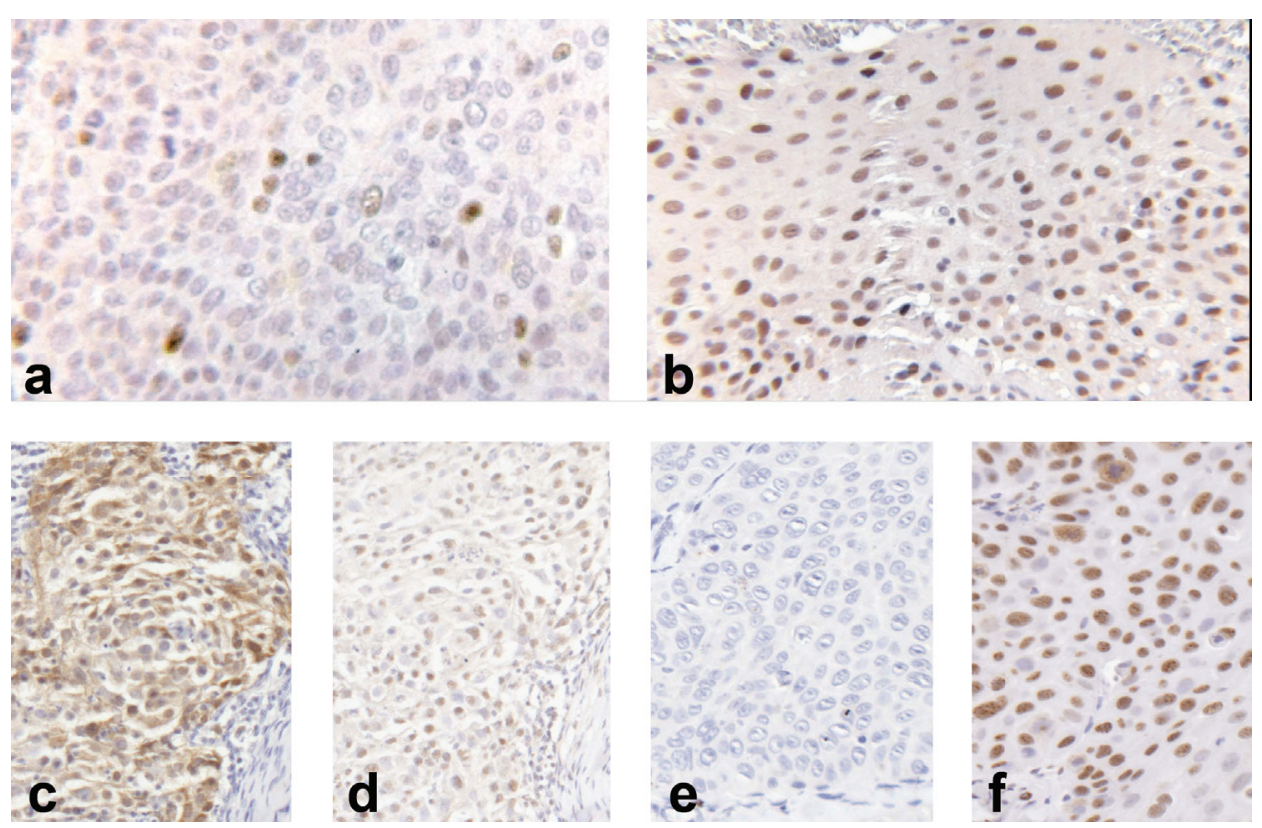


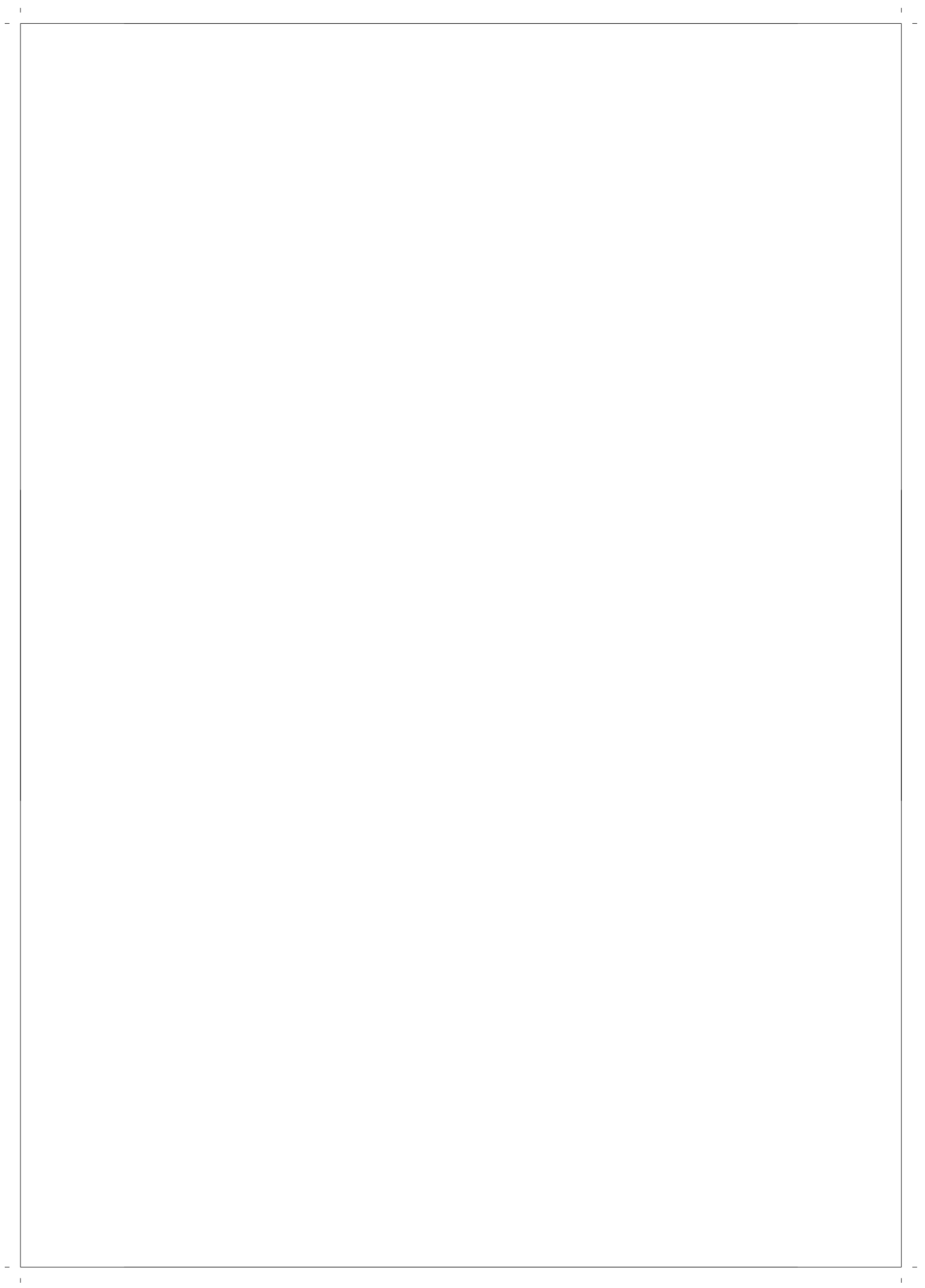




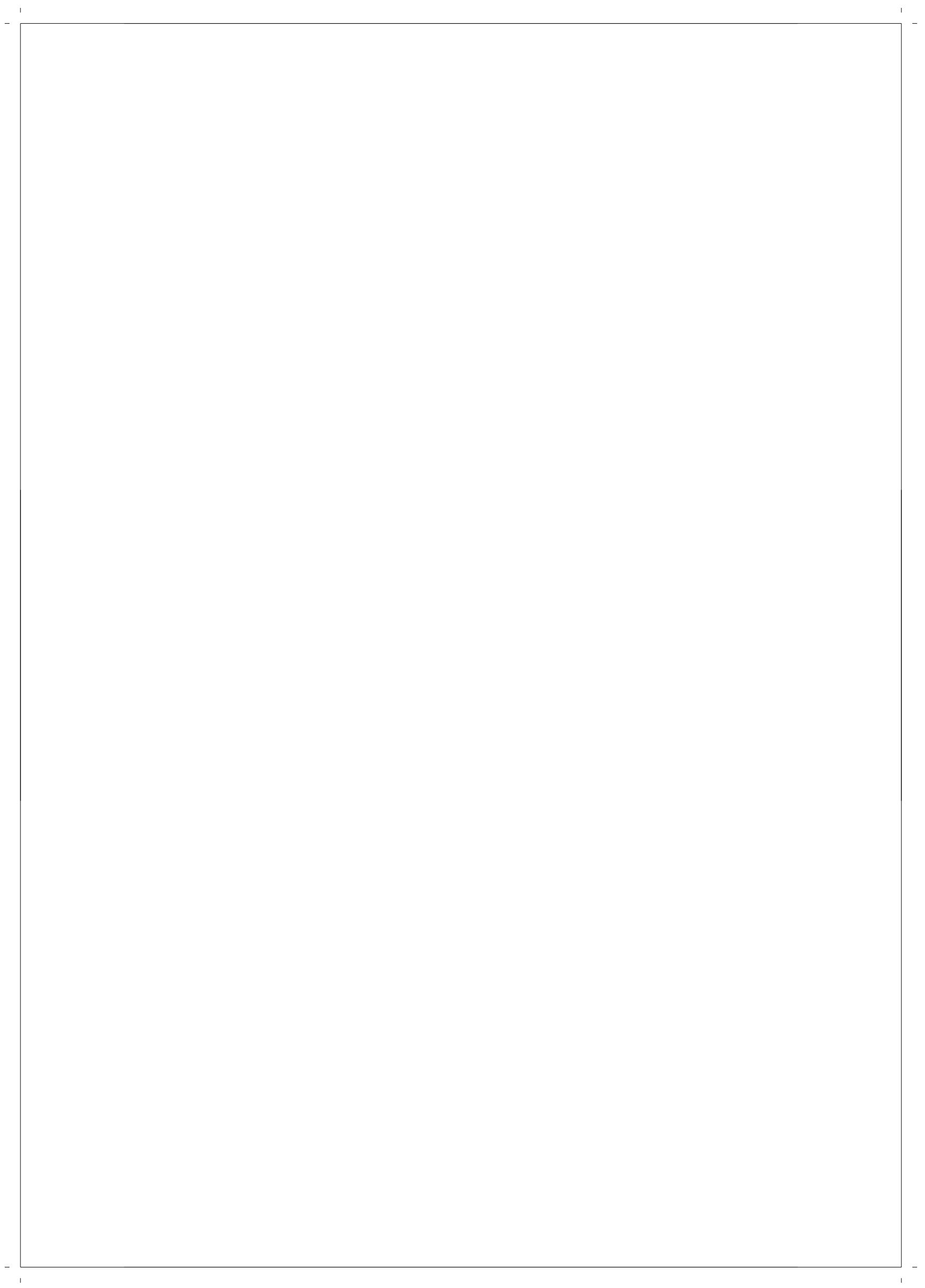



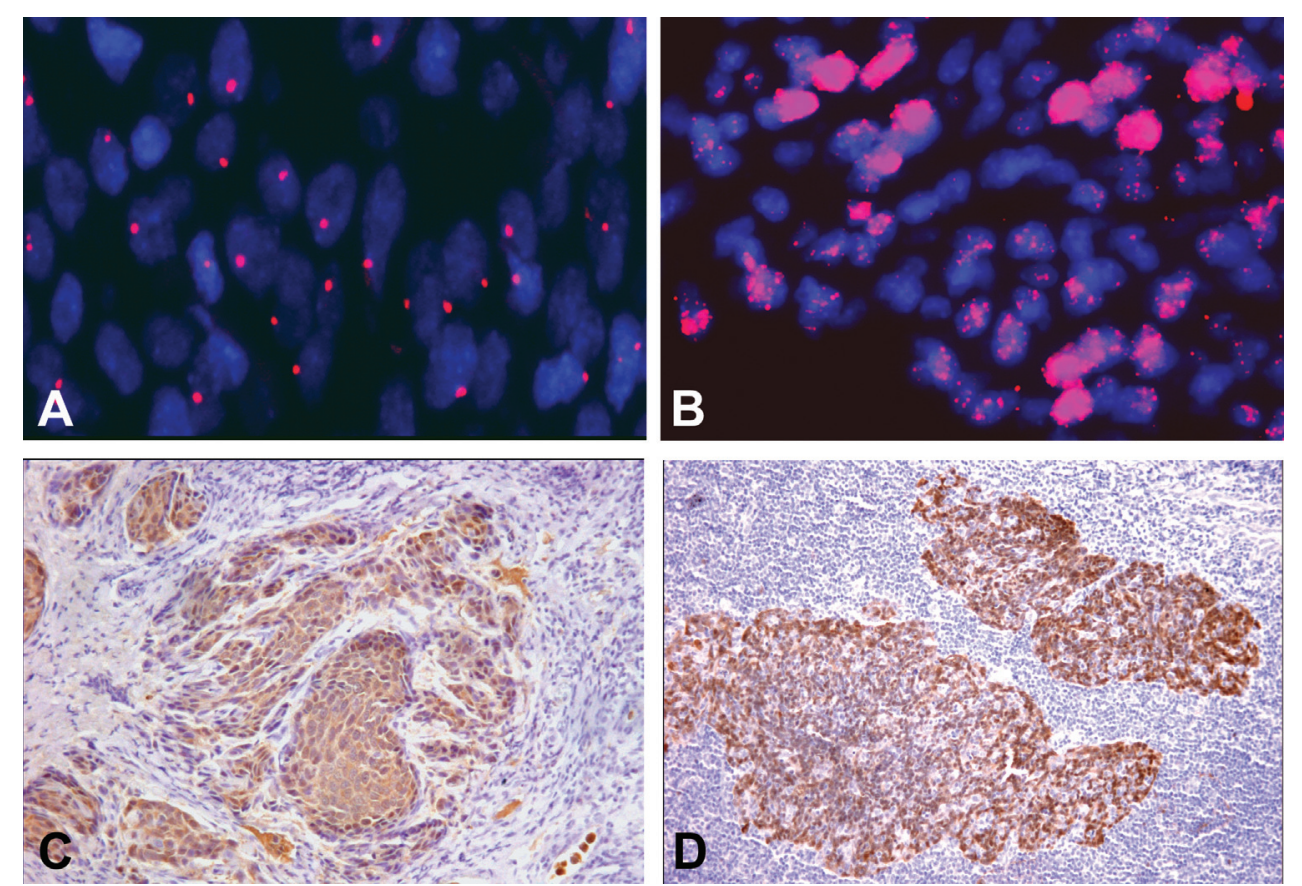

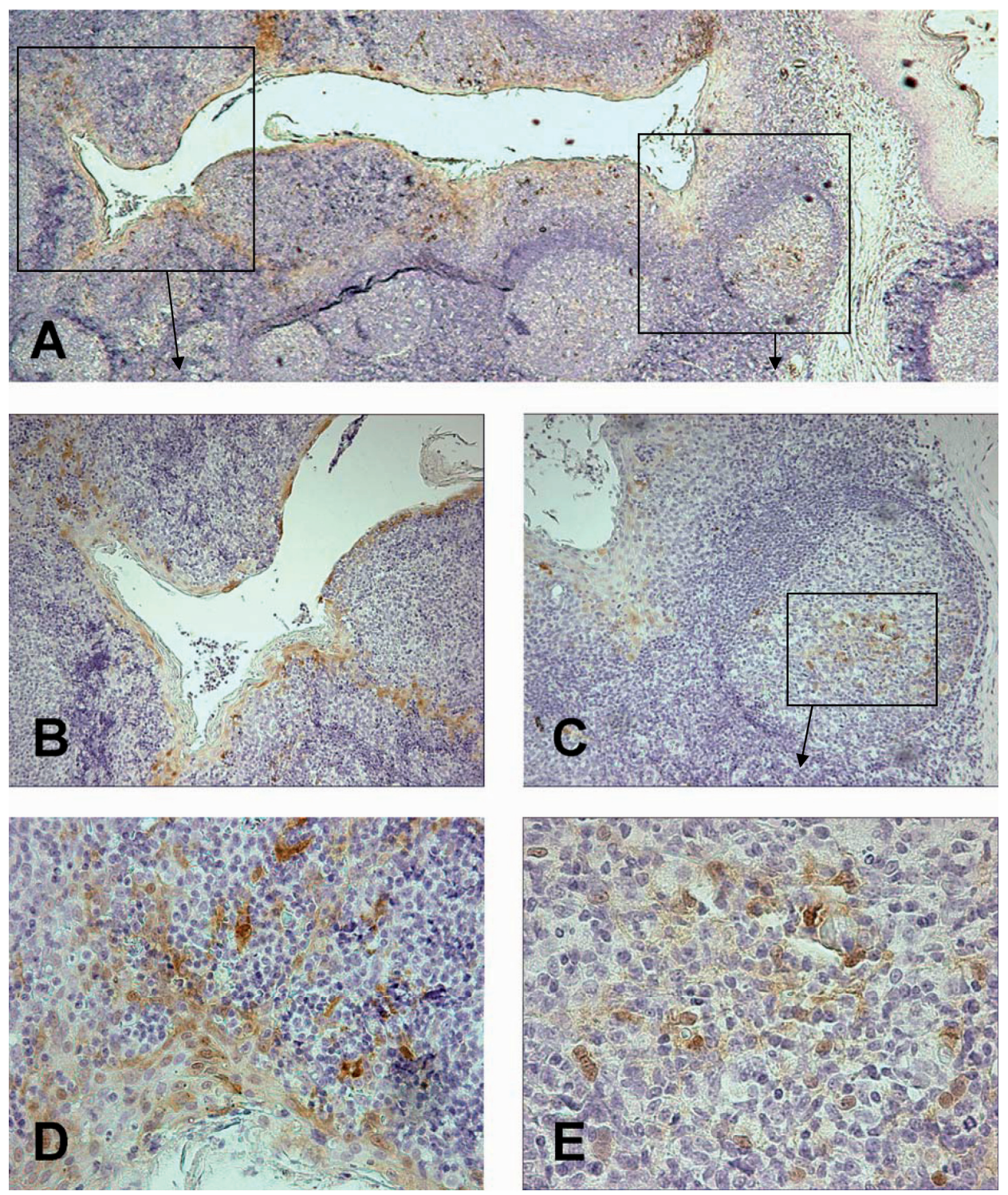


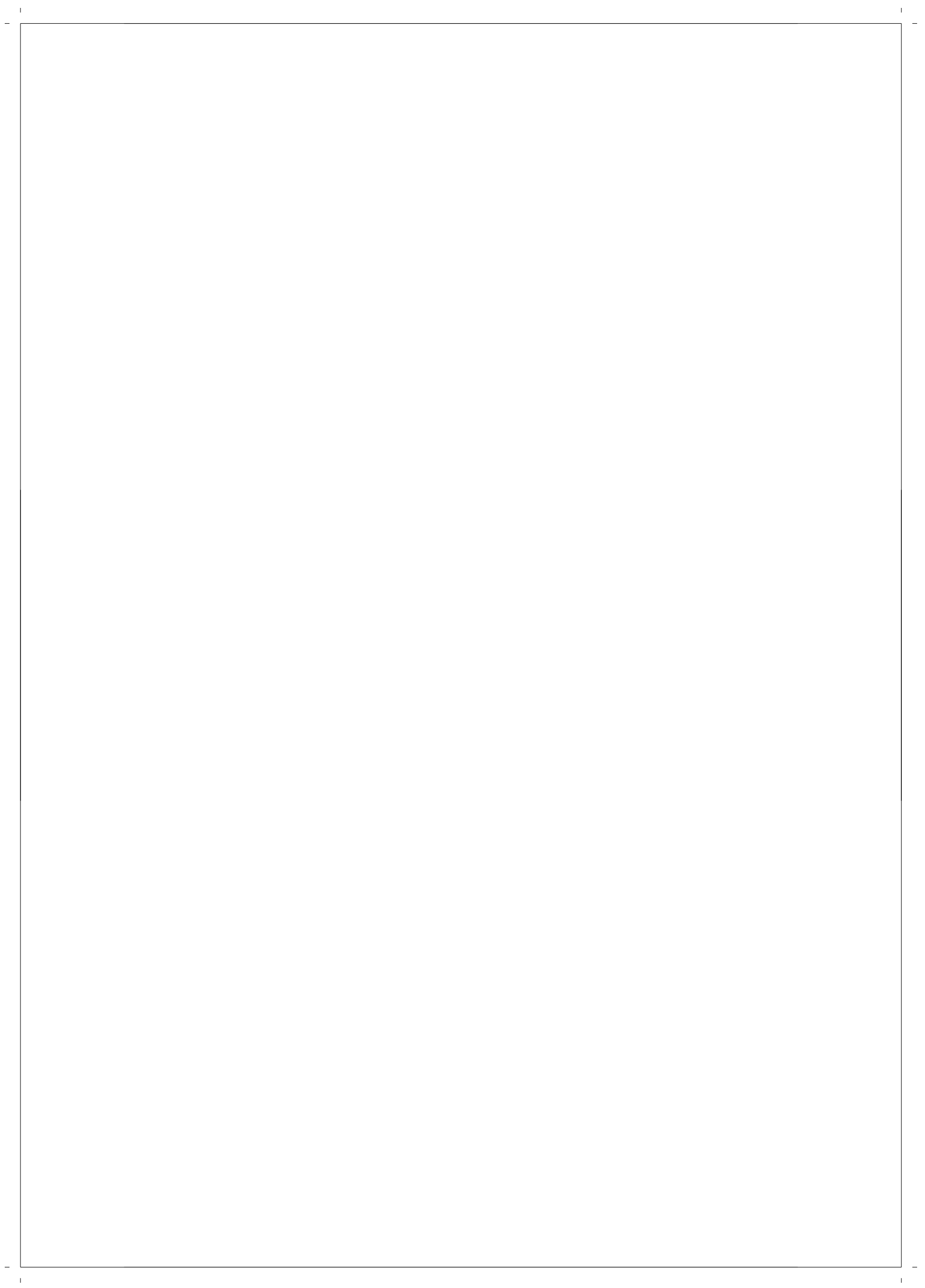




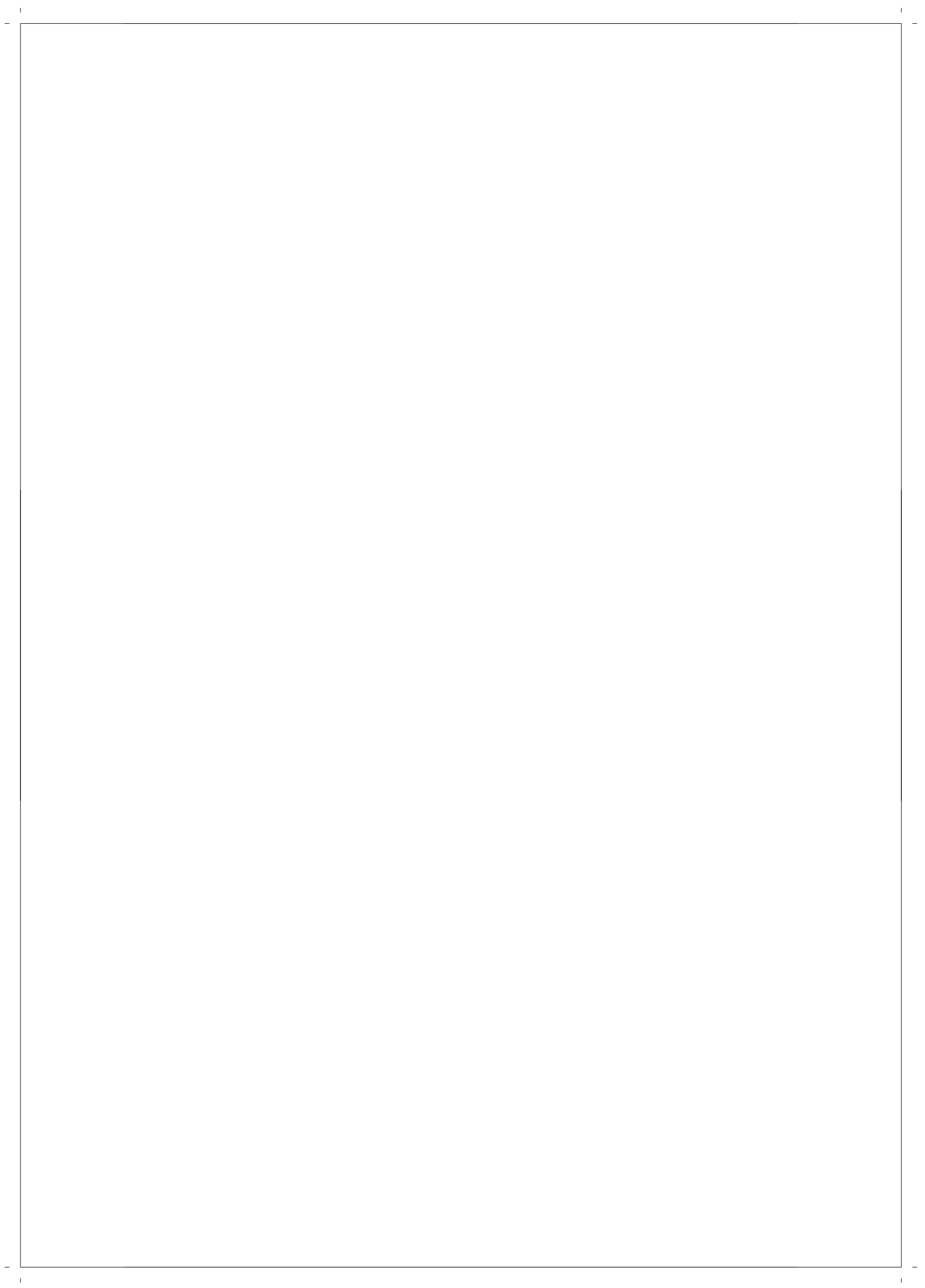



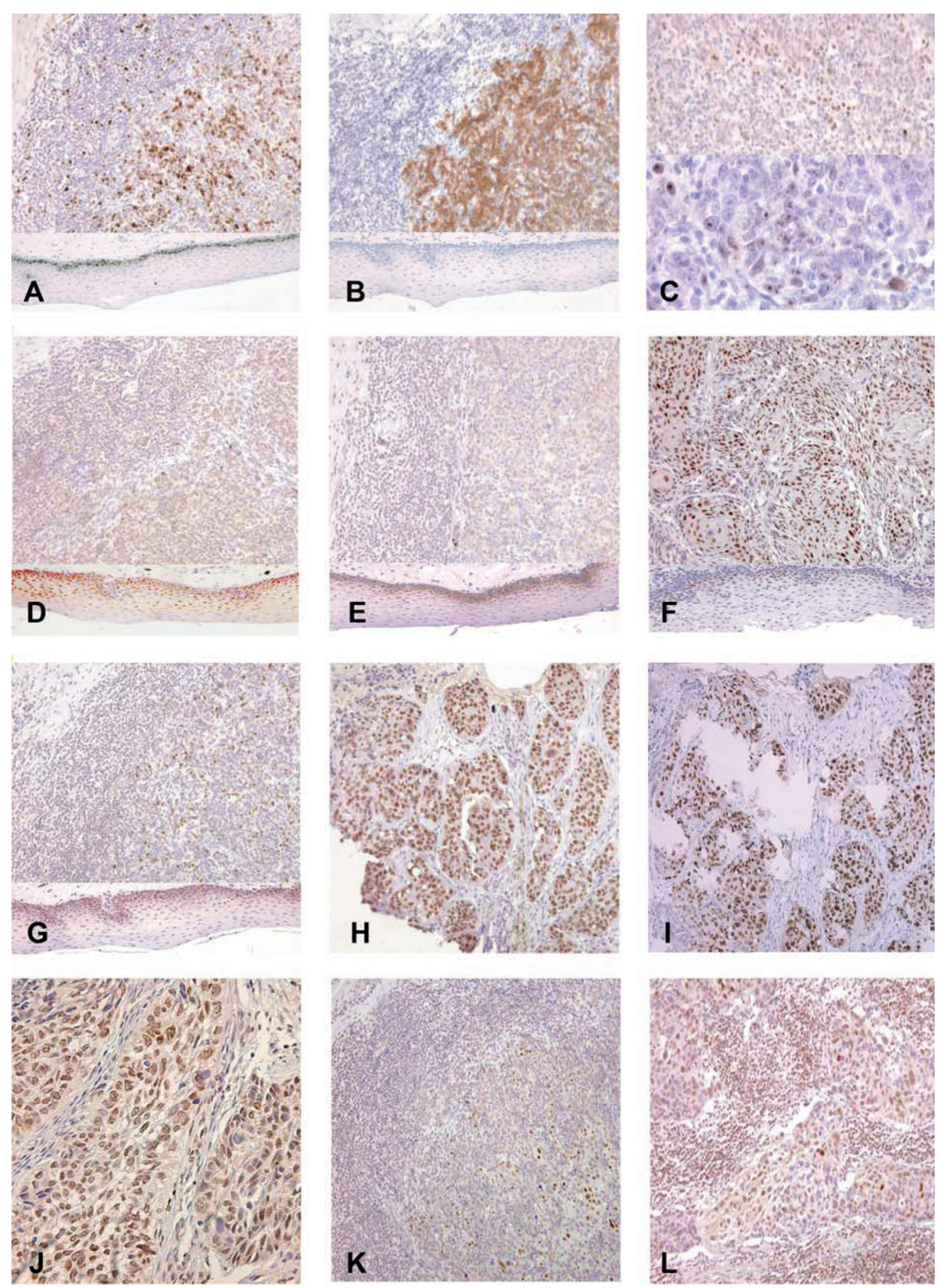